\title{
Mulheres recipientes:
}

recortes poéticos do universo feminino nas artes visuais

Flávia Leme de Almeida

ALMEIDA, FL., Mulheres recipientes: recortes poéticos do universo feminino nas artes Visuais [online]. São Paulo: Editora UNESP; São Paulo: Cultura Acadêmica, 2010. 238 p. ISBN 97885-7983-118-8. Available from SciELO Books 〈http://books.scielo.org>.

\section{(1) (1)(2)}

All the contents of this chapter, except where otherwise noted, is licensed under a Creative Commons Attribution-Non Commercial-ShareAlike 3.0 Unported.

Todo o conteúdo deste capítulo, exceto quando houver ressalva, é publicado sob a licença Creative Commons Atribuição Uso Não Comercial - Partilha nos Mesmos Termos 3.0 Não adaptada.

Todo el contenido de este capítulo, excepto donde se indique lo contrario, está bajo licencia de la licencia Creative Commons Reconocimento-NoComercial-CompartirIgual 3.0 Unported. 


\section{MULHERES}

RECIPIENTES

RECORTES POÉTICOS DO UNIVERSO

FEMININO NAS ARTES VISUAIS

FLAVIA LEME DE ALMEIDA 


\section{Mulheres RECIPIENTES}


CONSELHO EDITORIAL ACADÊMICO

Responsável pela publicação desta obra

Alexandre Luiz Mate

Omar Khouri

Rejane Galvão Coutinho 
FLAVIA LEME DE ALMEIDA

\title{
Mulheres \\ RECIPIENTES
}

\author{
RECORTES POÉticos \\ DO UNIVERSO FEMININO \\ NAS ARTES VISUAIS
}




\section{(C) 2010 Editora UNESP}

\section{Cultura Acadêmica}

Praça da Sé, 108

01001-900 - São Paulo - SP

Tel.: (0xx11) 3242-7171

Fax: (0xx11) 3242-7172

www.editoraunesp.com.br

feu@editora.unesp.br

CIP - Brasil. Catalogação na fonte

Sindicato Nacional dos Editores de Livros, RJ

\section{A446m}

Almeida, Flávia Leme de, 1978-

Mulheres recipientes: recortes poéticos do universo feminino nas artes visuais / Flávia Leme de Almeida. São Paulo: Cultura Acadêmica, 2010.

il.

Inclui bibliografia

ISBN 978-85-7983-118-8

1. Mulheres na arte. 2. Mulheres artistas. 3. Feminisno e arte. 4. Arte moderna-Século XX. 5. Arte moderna-Século XXI. I. Título 11-0139

CDD: 709

CDU: 7.036

Este livro é publicado pelo Programa de Publicações Digitais da Pró-Reitoria de Pós-Graduação da Universidade Estadual Paulista "Júlio de Mesquita Filho" (UNESP)

Editora afiliada:

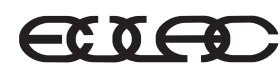

Asociación de Editoriales Universitarias de América Latina y el Caribe

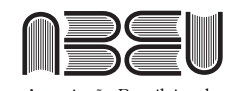

Associação Brasileira de Editoras Universitárias 
Dedico este livro à memória da minha mãe,

a Grande Mãe. 



\section{Agradecimentos}

Agradeço a meus pais, Hélvio e Mali, pela vida, amor incondicional e colaboração em todos os momentos;

A meus tios, Manolo e Nany, pelo amor, apoio e por serem meus "pais postiços";

A todos meus mestres que me ensinaram e me ajudaram a chegar até aqui, especialmente à professora Lalada Dalglish;

À professora Mariza Bertoli pelas valiosas colocações e comentários na entrevista concedida;

A meus amigos de agora e sempre, especialmente Vanessa Lambert, Vera Cozani, Soraia Savaris, Carol Ribas, Thiago Freire, Neusa Cézar, Daniela Matarazzo, Cecília Cabañas, Flávia Amadeu;

A Asnésio Bosnic Botões pela ajuda mais que preciosa em vários momentos desta pesquisa, pela paciência, pelo carinho, pelo amor e também pelo seu modo estimulante e contagiante de encarar a vida um companheiro mais que querido! 



\section{SUMÁRIO}

Prefácio 11

Apresentação 15

Introdução 17

1 No princípio era a cerâmica:

nossos ancestrais pré-históricos 25

$2 \mathrm{O}$ feminino na arte e a arte do feminino: movimentos libertários do século XX 55

3 As germinadoras: as artistas (es)colhidas através dos recortes poéticos 75

4 A mulher, forma ou forma? Recipientes do vir a ser: depoimento de artista 115

Considerações finais 179

Anexo 185

Referências bibliográficas 229 



\section{Prefácio}

O livro Mulheres recipientes é resultado da dissertação de mestrado de Flavia Leme de Almeida. Apresentada no Instituto de Artes da Unesp, sob a orientação da professora Lalada Dalglish, revelou-se um estudo corajoso do olhar feminino sobre a vida, da mulher na arte, e no imaginário dos povos ancestrais. A autora pegou o fio da meada no âmbito do estético para colocar-nos nas tramas da malha simbólica sempre na perspectiva do feminino como matriz. Conduz a argumentação em um percurso que vai das primeiras esculturas votivas, propiciatórias da fertilidade para a obra de seis artistas contemporâneas e finaliza com o próprio trabalho, em depoimento onde se coloca entre as artistas escolhidas. Isso mostra a maturidade da autora na compreensão do campo de produção simbólica e na percepção do seu próprio corpo nas formas escultóricas.

Para lembrar a imagem da mulher, ligada à terra e à sobrevivência da espécie, vai ao passado remoto em busca das pequenas Vênus só seios e nádegas - deusas portáteis, propiciadoras da magia da fertilidade, com suas pernas em cunha para fincar na terra durante o culto, como se fosse o arado primitivo, que fazia o sulco para a semeadura. Esses paus de sulcar para semear teriam desvelado o papel do homem na procriação, antes oculto pela crença na fertilização lunar - o matriarcado ancestral era absoluto. Pensar o mun- 
do simbólico feminino, para a autora, consiste em aproximar-se da obra de artistas contemporâneas destacadas, começando por Frida Kahlo, com sua figuração confessional, incisiva, perplexa, eivada de momentos de profunda dor e também de júbilo pela descoberta do seu lugar no mundo. A percepção da sua força interior diante da interdição da maternidade sonhada e a conquista da identidade mexicana, forjada na memória-sentido, vêm à luz em obras vigorosas que, certamente não querem ser arquivadas na generalidade das "questões de gênero". Suas obras são narrativas plásticas fortes, que a destacam como uma das primeiras artistas da nova figuração vanguardista na América Latina. Da mesma maneira a opção pela escultora francesa Louise Bourgeois, revela a intenção da autora de mostrar como a vida dessas mulheres se deixa ver em cada segmento da sua arte, como a história pessoal e a social amadurecem gerando uma imagística na qual todos nos encontramos. É isso afinal que garante o estatuto da arte, o fato de sermos fotografados naquilo que vemos, como diria Jacques Lacan.

Bourgeois sublimou na arte seu desencanto com o pai e a sua identificação com as frustrações da mãe e a admiração do seu fazer quase ritualístico no tecer e restaurar tapeçaria. As Mulheres-casa têm a mesma sugestão simbólica das Aranhas, que tecem a teia, ambas aludem ao feminino e ao amparo. Tanto no sentimento do trágico e da ternura como no desejo de devorar o pai, a artista nos coloca nas Células, que exorcizam o ressentimento e a dor - é a lição do medo e do enfrentamento dos nossos fantasmas. Assim como o mote da arte de Louise é a reconstrução da memória vivida, a arte de Celeida Tostes revela-nos um percurso artístico em que vida e obra caminham em direção a uma elaboração simbólica coletiva, sempre a partir da sua matéria primordial - a argila. O memorial cultual no Morro do Chapéu Mangueira é a expressão da capacidade individual e do trabalho coletivo animado por essa artista cujas performances lhe valeram o título de a grande sacerdotisa do barro. Tanto Louise como Celeida sentiam no próprio corpo o arrepio que chamam de inspiração. Este é o elo entre as artistas (es) colhidas pela autora. Niki de Saint Phalle, que nos anos sessenta 
ligou-se ao Novo Realismo da vanguarda francesa, teve também que superar um trauma violento, o estupro pelo próprio pai. Os happenings - "macabros e deliciosos rituais" como ela os apelidourealizaram a catarse necessária e ela encontrou-se na sua expressão mais conhecida - as Nanas. Também nesse percurso artístico a sensação do corpo invadido se transforma em arte. Essas deliciosas esculturas negras, volumosas, sensuais, inicialmente eram armadas em arame e revestidas em papel machê, trabalhadas com tecidos e lãs, porém as técnicas se multiplicaram. As Nanas tornaram-se fontes hilariantes e fantásticas esculturas penetráveis em acrílico e outros materiais resistentes, com cores gritantes e formas ousadas. Juntaram-se a cenas de teatro e formaram parques temáticos inusitados. A mágoa vestiu-se com cores de festa para celebrar a vida.

Judy Chicago, que escolheu seu nome em homenagem à terra natal, mostra uma tendência feminista não só na arte como na docência. Como professora quebrou tabus e questionou tradições culturais, encantou as jovens alunas muitas vezes criando problemas com as instituições colegiais. Sua obra de maior envergadura foi The dinner party (O jantar festivo) - uma instalação monumental em que ela partilha o banquete com mulheres famosas no mundo da filosofia, da ciência e da arte, personagens trágicas ou vitoriosas. Contou com a participação de vários profissionais e além da viagem no mundo das mulheres célebres, a obra exigiu todo um aprendizado técnico de pintura sobre cerâmica, durante a sua preparação por cinco longos anos. A história da obra virou livro. Para completar esse grupo, a autora traz a artista cubana Ana Mendieta, cuja morte prematura é ainda um mistério, infelizmente com sugestões macabras. A intenção da autora foi mostrar uma artista totalmente ligada à terra, a ponto de representar-se como parte dela, de querer fundir-se com ela. Nas silhuetas ou nas esculturas rupestres, ela conta o desejo de retornar a Cuba de onde foi levada pelos pais ainda criança, sentindo que lhe roubaram o chão. Seu desejo virou utopia e as suas performances, propiciações mágicas de uma nostalgia comovente.

Flavia coloca-se como partícipe efetiva nesse campo de produção artística. Vive o seu papel entre as artistas (es)colhidas, e faz 
o depoimento poético de quem trilhou esse caminho, atenta aos encantos e desencantos que a arte nos mostra e dividindo conosco seu aprendizado. Mostra seu diário de trabalho, desde as pegadas titubeantes em busca do símbolo, esboços, rabiscos e versos. Caminhou pensamento, sentimento e mãos, colhendo flores e espinhos às margens do caminho mas sobretudo, aprendendo e valorizando a cerâmica, o ofício ligado à magia, de transformar o barro em pedra com o auxílio luxuoso do fogo, devolvendo a terra à pedra que era eis o percurso ao inverso, a busca do princípio, como se o rio rebelado voltasse à sua nascente, quisesse conhecer a fonte-Mãe. Beber dessa fonte-Mãe - eis a lição solidária da vida, pois somos todos um e todos retornaremos ao ventre da grande Mãe Terra, a Pachamama.

De início estranhei o título que me foi apresentado, pensei: $M u$ lheres recipientes, o que é isso? Soou duro, utilitário, até impróprio. Aos poucos, ao pensar o regime lunar da imagem, a sua fonte primordial, a expressão abrandou-se e os símbolos fundamentais compareceram um a um, re-ci-pi-en-tes, digestivos, profundos. Imagens ligadas ao feminino, ao continente, ao amparo, à fecundidade, à gestação, à deglutição, ao plantio e à colheita. Mulheres recipientes é o título que a autora deu à série de objetos escultóricos regulares, côncavos com incisões e incrustações, que são o fruto do seu próprio exercício artístico. Essas esculturas revelam a intimidade com a prática da cerâmica e o prazer no trato com a carne da Mãe Terra.

A simbologia que ela traz à luz nessas peças escultóricas celebra a reverência quase mística à natureza. As pequenas cabeças peladas que nascem da peça semi-esférica, inclinam-se sobre o oco. Parecem simbolizar uma confissão de humildade diante do que se pode colher na copa da vida, reverência ao destino, ao tempo domesticado para enfrentar o medo da morte. A densidade do continente é o oco, o próprio vazio. Porém esse oco é cheio de sonhos e presságios, como um caldeirão borbulhante, que prepara a poção mágica que alimenta a esperança. As mulheres recipientes são como a copa que se enche e dá de beber, e quanto mais se bebe, mais ela se enche, como um coração pulsante de mãe amorosa. 


\section{ApresentaÇão}

"Não se nasce mulher, passa-se a sê-lo"

Simone de Beauvoir

Nasci cromossomicamente ${ }^{1}$ XX. Tornei-me mulher. Mulher, moça, menina, fêmea, feminina; sempre tive interesse por tudo que envolvesse esse universo, o meu universo: as emancipações, os abusos, os direitos, as explorações, as conquistas, as violações, o poder de gerar outras vidas, de alimentar, de acolher, de guardar, de reter... O encanto e o espanto que esses assuntos me causam, instigam-me a buscar e saber mais, para entendê-los melhor e, consequentemente, entender a mim mesma. É por esta razão que falar do universo feminino me soa tão familiar e, paradoxalmente, ainda é um mistério a ser desvendado.

Desde muito cedo já sabia que o universo artístico seria minha vereda pessoal. Minha primeira escolha acadêmica foi Arquitetura

1 Cromossomo [De crom(o)- + -somo.] Sm. 1.Citol. Genét. Unidade morfológica e fisiológica, visível ou não ao microscópio óptico, e que contém a informação genética. Cada espécie vegetal ou animal possui um número constante de cromossomos./ Cromossomo sexual. 1. Biol. Cromossomo que contém os genes que irão determinar o desenvolvimento dos órgãos sexuais e dos caracteres sexuais secundários (cf. Ferreira, 1975). 
e Urbanismo, sendo que, após três anos, abandonei ao descobrir o vasto universo das Artes Plásticas. Hoje, depois de tanto tempo, percebo que acabei por agregar os conhecimentos de ambos, pois os volumes estiveram sempre presentes em meus desenhos e pinturas, fosse em forma de colagem, encaixe, volumetria ou qualquer movimento que os projetasse no espaço. Logo, as disciplinas que diziam respeito à linguagem tridimensional eram as que mais me agradavam.

A argila ${ }^{2}$ era em potencial um excelente suporte para que eu pudesse desenvolver objetos no espaço. Na verdade eu sempre me encantei com as inúmeras possibilidades que a plasticidade do barro poderia me oferecer. Assim, com a escultura eu poderia continuar a tratar o espaço em três dimensões. Por esta razão, esse material era quase sagrado para mim. Foi de modo muito respeitoso e paulatino, na disciplina "Linguagem Tridimensional", ministrada pela professora Lalada Dalglish, que me aprofundei na pesquisa da cerâmica. Embora fosse uma das muitas disciplinas práticas oferecidas pelo curso de bacharelado em Artes Plásticas da Unesp, foi especificamente com o aprendizado da cerâmica que despertei para um novo universo artístico.

A pesquisa que apresento ${ }^{3}$ é, portanto, a gestação destes longos e instigantes anos de pesquisa e produção. É também um outro meio de buscar mais informações sobre o assunto que sempre foi meu foco de interesse pessoal: a mulher. E por esta pesquisa ter, desde o início, características tanto poéticas (teóricas), quanto plásticas (práticas), percebo que ela se configura em constante mutação e desenvolvimento, logo, não se esgota neste momento. Do mesmo modo que sendo uma mulher, aprendi a respeitar e me adaptar aos meus ciclos e transformações mensais de humor, hormônios, fluxos e dores, também aprendi que a arte é um processo contínuo e cíclico. Vivo e convivo com meus ciclos artísticos na busca constante de mantê-los como um recipiente, como são aliás, todas as mulheres pela sua própria natureza.

2 Argila: 1. Min. Silicatos de alumínio hidratados, que constituem os minerais ditos argilosos. 2. Pet. [...]; grega, barro (cf. Ferreira, 1975).

3 A íntegra dessa pesquisa está disponível em <http://www.ia.unesp.br/pos/ stricto/artes/dissertacoes_artes/2009/dissertacao_flavia_lemealmeida.pdf $>$. 


\section{INTRODUÇÃO}

Historicamente, homens e mulheres sempre cumpriram papéis sociais bem definidos. Muito desta distinção deveu-se as evidentes diferenças biológicas entre ambos. Inventamos diversas maneiras de explicar e perpetuar esses comportamentos. Através dos mitos, das religiões, dos rituais, dos contos, histórias etc. e de tudo mais que fosse possível ser criado por nossas mentes, mantivemos tais padrões como se fossem leis.

As mulheres foram, durante um longo período da história, relegadas a cumprir apenas o papel de esposas, mães, donas de casa, sem ter a possibilidade de estudar ou de seguir uma carreira. É relativamente recente a inclusão das mulheres no mercado de trabalho, o que anteriormente era disponível apenas aos homens: o da atuação fora do lar e do desenvolvimento intelectual. $\mathrm{O}$ mesmo pode ser observado no mundo das artes. Foram poucas as mulheres que puderam ter acesso a esse mundo e, menos ainda, foi a constatação e reconhecimento das mesmas em registros e livros de história da arte. Durante muito tempo na história, se uma mulher quisesse estudar ou mesmo ser uma artista, sua única opção seria ir para um convento, onde lá aprenderia a ler, escrever e se dedicar a alguma atividade artística.

Não é de hoje que as atribuições da mulher na sociedade e sua incursão no mundo intelectual e profissional é investigado. Muito 
já foi escrito, discutido e tratado nos últimos séculos, com diferentes enfoques às mais diversas áreas do conhecimento humano. Entretanto, na história da arte, ainda temos um vasto campo para fomentar investigações acerca dessas mulheres que se tornaram artistas e suas respectivas obras. A maioria das nossas fontes de pesquisa sobre arte feminina são advindas de autores, europeus e norte-americanos que, obviamente, falam sobre artistas dessas localidades. Consequentemente, temos poucos registros sobre a produção de artistas mulheres contemporâneas que abordem a temática do feminino na América Central e do Sul. Por isto, houve certa dificuldade em pesquisar e encontrar um número significativo de artistas consagradas que fossem da América Latina. Há, certamente, algumas poucas artistas latino-americanas que conseguiram notoriedade internacional. Os registros de sua atuação podem ser mais facilmente encontradas em livros e catálogos sobre arte feminista ou feminina ${ }^{1}$.

A arte dita "feminina" foi tema de muitas pesquisas entre as décadas de 1960 e 1980. Eram mulheres pesquisadoras interessadas em levantar uma história que deu nenhuma ou pouca chance às artistas. Escritoras como Pollock e Parker (1981) demonstraram que em alguns momentos foram feitas concessões para que a mulher pudesse ter uma carreira artística. Nesses casos, muitas das vezes, era preciso que ela abdicasse sua condição feminina ou mesmo tivesse que produzir obras que reforçassem a representação da figura da mulher como virgem, esposa ou mãe - uma iconografia do papel social da mulher vigente durante centenas de séculos.

Linda Nochlin foi uma das primeiras historiadoras e professoras de arte que buscou informações precisas sobre artistas mulheres e suas obras durante os últimos séculos. No artigo "Why have there been no great women artists?" (Por que não houve grandes artistas mulheres?), publicado em 1971 na revista ART News, Nochlin (1988) questionou as estruturas sociais que influenciaram não só

1 A noção do que é considerada uma arte feminina ou feminista será discutida no capítulo 2 . 
a arte produzida por mulheres, mas todo o aparato instrumental da história da arte. A autora evidenciou as práticas sexistas, assim como os antigos valores que insistiam em perpetuar-se pelos conservadores, galeristas e museólogos. Neste ensaio, ela também afirmou que existiam muitas estruturas hierarquizadas na história da arte e que estas tendiam a valorizar um tipo de arte em detrimento de outro. A pintura, a escultura e a arquitetura são consideradas, nesse entender, como artes "maiores" e a cerâmica, o bordado e a tapeçaria como sendo artes menores. Interessante observarmos que as artes consideradas "menores" são, em sua maioria, atividades realizadas especificamente por mulheres. O nu feminino como tema de pinturas e esculturas foi amplamente explorado pelos artistas (homens) nas artes plásticas e, curiosamente, proibido às mulheres durante séculos o acesso aos estudos e treinamentos com modelos vivos (Senna, 2007).

A professora e historiadora da arte, Whitney Chadwick também é uma das importantes pesquisadoras neste campo. Em seu livro Women, art and society (1990), a autora fez um amplo levantamento dos mais variados materiais e técnicas, acrescentando, inclusive, as chamadas artes menores. Segundo Senna (2007), foram estas artes menores que fizeram com que as artistas mulheres entrassem de vez no hall da história da arte, resgatando um fazer tipicamente feminino. Ao considerarem que sempre houve uma produção artística feminina, essas autoras estavam desestruturando todo um modelo de discurso extremamente consolidado na história da arte. Modelo este que impunha um único modo de fazer arte e definia quem teria acesso à esse fazer: apenas o universo masculino.

Abordando um contexto semelhante ao das autoras citadas, a presente pesquisa Mulheres recipientes: recortes poéticos do universo feminino nas artes visuais tomou alguns importantes fatos artísticos ocorridos na história da arte e que tiveram uma coerência poética feminina. Este é, sem dúvida alguma, um tema que ainda tem muito campo para pesquisa, sobretudo se voltarmos nosso olhar para as artistas da América Latina e Caribe. As questões acerca do feminino não estão de todo esgotadas. Ainda mais no que 
diz respeito ao vasto e complexo universo da arte contemporânea. Logo, o papel de uma pesquisa é abordar assuntos que ainda necessitem ser investigados e, consequentemente, melhor compreendidos. No caso desta pesquisa, abordaremos a obra de algumas artistas do continente americano e os símbolos do universo feminino que aparecem no modo como se expressam artisticamente.

Este livro não tem a pretensão de esgotar o tema das artistas da história que não foram reconhecidas ou que tiveram suas imagens apagadas, nem tão pouco, cabe aqui fazer a crítica da sociedade pelo modo como tratou as mulheres durante séculos. A proposta foi conduzir a pesquisa, através do olhar artístico feminino contemporâneo. Especialmente ao destacar o modo como algumas dessas artistas foram e são capazes de se ver e serem vistas no universo das artes visuais. Assim, desta forma exposto, pretendemos ressaltar que a mulher pode ser reconhecida integralmente, não apenas em âmbito social, mas também intelectual, artístico ou, até mesmo, ritualístico. ${ }^{2}$

A pesquisa aborda algumas manifestações artísticas em que a temática da obra de arte é a mulher, seu próprio corpo e imagem. Alude a conceitos e ideais sobre o feminino e a forma como as artistas elaboram e expressam tais temas, especialmente após o feminismo. ${ }^{3}$ A arte contemporânea transita de forma livre e inventiva pelo tema da autorrepresentação tão carregado de conotações culturais. Mormente no que tange à representação feminina. Já não há mais a hierarquia da tradicional belas artes e nem tão pouco uma exclusividade masculina, o que estimula a reflexão sobre algumas artistas, entre tantas que atuaram no século XX e atuam no XXI.

2 Neste ponto, queremos nos ater a um período da história, nas sociedades ancestrais, em que os rituais sagrados de fertilidade eram realizados especificamente por mulheres. Observamos também que alguns rituais ligados à mulher até hoje perpetuam (como nas cerimônias de primeira comunhão, debutante, casamento) a ideia de que ela deve usar uma vestimenta especial para se iniciar em uma nova fase da vida.

3 Feminismo [Do fr. féminisme.] Sm. Movimento daqueles que preconizam a ampliação legal dos direitos civis e políticos da mulher, ou a equiparação dos seus direitos aos dos homens (cf. Ferreira, 1975). 
Para desenvolver esta pesquisa, optamos pelo método descritivo-qualitativo. Através desta abordagem foi possível desenvolver relações dinâmicas entre as artistas e suas obras, entre a subjetividade do sujeito e do objeto da pesquisa. As múltiplas possibilidades de expressão e interpretação que existem em uma obra de arte estão diretamente ligadas ao modo como o "sujeito" (as artistas) se relaciona com o "objeto" (obras de arte). "De fato, não pode haver consciência (= sujeito) desvinculada do mundo (= objeto)" (Rampazzo, 2002, p.59). Assim, as artistas estudadas foram compreendidas pelo modo como traduziram artisticamente suas experiências, vivenciadas em um determinado espaço-tempo. Para compor o grupo de artistas selecionadas nesta pesquisa, consultamos o livro Women artists - mulheres artistas nos séculos XX e XXI, de Uta Grosenick (2005). A autora alemã selecionou as artistas, na maioria européias ou norte-americanas, que lhe pareceram de maior envergadura nos últimos dois séculos. Observamos que dentre as cinquenta e seis artistas selecionadas por Grosenick, apenas duas são de origem latino-americana: Frida Kahlo (mexicana) e Adriana Varejão (brasileira). A despeito de ter dedicado um livro exclusivamente para artistas do sexo feminino, ela afirmou que sua publicação não teve um cunho sexista, mas procurou abranger informações amplas sobre vida e obra, técnicas e modos de expressão, de artistas que impactaram e influenciaram a arte no século XX. "A crítica tradicional do feminismo, que prefere fugir ao debate sobre os mecanismos sociais e à verdadeira guerra real dos sexos, argumenta que a boa arte não tem sexo." Aliás, pelo contrário, uma vez que a crítica contemporânea afirma que a diferenciação sexual é, mais do que um fato, uma construção social. ${ }^{4}$ A autora também quis demonstrar que a arte feminista ou feminina não é a mesma coisa que arte feita por mulheres. "A expressão 'arte feita pelas mulheres' cobre uma multitude de abordagens e de opções expressivas tão grande quantas mulheres artistas há." (Grosenick, 2005, p.5)

4 A esse respeito, Simone de Beauvoir já havia mencionado que uma mulher apenas se torna mulher segundo o ponto de vista de outrem, no caso, da visão masculina (Beauvoir, 1970). 
Após essa leitura, ${ }^{5}$ optamos por algumas artistas, tomando por base a relevância de sua atuação artística - olhares femininos diversos através da arte. Essa escolha priorizou os suportes utilizados, assim como, o repertório cultural de cada uma delas. Para desenvolver este estudo, dividimos o livro em quatros capítulos:

O capítulo 1 é dedicado aos assuntos relativos à relação entre a mulher e a cerâmica nas culturas ancestrais. As sociedades eram organizadas de modo a definir claramente os papéis dos homens e das mulheres, determinados por suas diferenças fisiológicas - o homem, fisicamente mais forte responsável pela caça e pela luta, a mulher, responsável pelo cuidado e assistência da prole e o trabalho agrícola de cultivo e colheita. Neste período, a natureza era sagrada, envolvida no assombro do desconhecido e digna de reverência e culto. O mistério também envolvia as mulheres. Por serem capazes de gerar, garantindo a perpetuação da espécie humana, elas estavam diretamente ligadas a outro grande mistério: a fertilização e germinação do solo.

No capítulo 2, desenvolvemos um breve recorte sobre a trajetória e os questionamentos acerca das manifestações sociais, políticas e artísticas das minorias, especificamente das conquistas femininas no século XX. Abordamos como a questão do gênero influenciou as artes no ocidente, desde que o sistema patriarcal configurou-se. Apresentamos breves biografias de algumas artistas atuantes entre os séculos XX e XXI que, de alguma forma, configuraram em suas obras temas sobre o universo feminino.

Apresentamos no capítulo 3 aspectos biográficos e considerações sobre as obras de seis artistas contemporâneas selecionadas do século XX que apresentam uma poética do feminino: Frida Kahlo

5 Outra fonte importante de pesquisa foram as ferramentas de busca na internet, especificamente os sites: http://www.artcyclopedia.com/artists/women.htm (uma base de dados virtual com centenas de artistas e links para os mais importantes museus de arte do mundo) e http://www.nationmaster.com/encyclopedia/Women-Artists (uma vasta compilação de fonte de dados, onde foi possível encontrar informações sobre mulheres artistas do período medieval, do renascimento, do barroco e do século XVIII e XIX). 
(1907-1954), Louise Bourgeois (1911), Celeida Tostes (19291995), Niki de Saint Phalle (1930-2002), Judy Chicago (1939) e Ana Mendieta (1948-1985). Observamos como cada artista se expressa plasticamente.

O capítulo 4 é dedicado à produção em cerâmica da autora da pesquisa. Mulheres recipientes é um conjunto de obras em escultura cerâmica, em forma de potes antropomórficos. Estas peças aludem ao corpo e, indiretamente, também à condição da mulher, ou seja, o poder de gerar e os múltiplos e profundos significados atribuídos à mulher, através da história da humanidade. Na produção artística da autora, o fio condutor está no significado da palavra recipiente. Uma vez que todas as peças têm o formato côncavo, são continentes, remetem ao pote, ao container, ao útero, à barriga, ao ventre materno, à genitália, aos seios, e a todas as curvas do corpo da mulher. A autora faz aqui um depoimento de artista sobre a técnica e o material utilizado - a cerâmica e a argila. Mulheres recipientes guarda uma afinidade profunda com a produção das outras artistas referidas nesta pesquisa. Neste capítulo final, fortalecemos também a ligação com a Grande Mãe. Mito de origem dos nossos antepassados, e todas as deusas votivas, esteatopigias e vênus propiciatórias da fertilidade, que motivaram a autora na sua arte e na sua pesquisa. A reflexão sobre o tema contribuiu para a transformação da série Mulheres recipientes e do próprio modo de expressão artística da autora. 



\section{1 \\ NO PRINCÍPIO ERA A CERÂMICA: \\ A VOLTA ÀS ORIGENS}

\section{Nossos ancestrais pré-históricos}

"Há milênios, sob todas as suas formas - barro esmaltado ou não, faiança, porcelana - a cerâmica está presente em todos os lares, humildes ou aristocráticos. Tanto que os antigos egípcios diziam "meu pote" para dizer "meu bem", e nós mesmos, quando falamos em reparar danos de qualquer espécie, ainda dizemos 'pagar os vasos quebrados' [payer les pots cusses].”

Claude Lévi-Strauss

No início era o barro - e não somente o verbo ou o Caos. ${ }^{1}$ Num tempo em que os seres humanos estavam mais próximos da natureza, ela era venerada e temida como uma divindade poderosa e respeitada como sendo algo sagrado e misterioso. Um dos modos

1 Referência bíblica, Evangelho segundo S. João, 1:1 - "No princípio era o Verbo, e o Verbo estava com Deus, e o Verbo era Deus. Ele estava no princípio com Deus”. Bíblia (1990). Referência mitológica grega no poema Teogonia, de Hesíodo (final do século VIII a.C.), que versa sobre a criação do mundo: "No princípio, era o Caos" abismo sem fundo, vazio primordial, matéria eterna, rudimentar, mas dotada de energia prolífica (Furlani, 1992, p.3-4). 
de refletir sobre a história das civilizações ancestrais é através da cerâmica. Por ser um dos poucos materiais que sobreviveram ao tempo, ${ }^{2}$ os arqueólogos puderam ter subsídios consideráveis para identificar e explicar o modus vivendi dos nossos antepassados. A cerâmica era feita com finalidades objetivas e simples, sendo de uso cotidiano (recipientes usados para alimentar o corpo) ou ritualístico (recipientes usados para alimentar a alma). Lévi-Strauss, no livro $A$ oleira ciumenta, relata diversos rituais de preparo da cerâmica, um deles chamado "ligadura dos potes" da aldeia de Awaxawi, era feito para obter-se chuva e consistia em preparar ritualisticamente dois potes decorados representando o homem e a mulher. Ambos permaneciam boa parte do ano enterrados e quando retirados deveriam ser protegidos do sol e levados para uma cabana revestida de terra para que o ritual pudesse acontecer (Lévi-Strauss, 1985, p.43).

Em muitos dos artefatos arqueológicos encontrados em várias partes do mundo podemos observar um fio condutor, uma busca pela beleza e perfeição. ${ }^{3} \mathrm{Na}$ sua maioria eram artefatos adornados com diversos tipos de representações gráficas que ilustravam o cotidiano real ou mitológico das pessoas daquela localidade e período (animais, caça, plantio, colheita, datas comemorativas etc.), assim como, também, grafismos abstratos e hieróglifos. No caso de urnas funerárias, não é raro encontrarmos nesses recipientes ${ }^{4}$ cerâmicos uma alusão direta ao corpo humano. As urnas eram bojudas na parte inferior; e na parte superior, próxima à abertura, tinham feições estilizadas de um rosto. Lembravam cabeças e ventres maternos, pois essas urnas simbolizavam um "retorno ao útero materno", à barriga da Mãe Terra, a Grande Deusa, e faziam parte dos rituais de sepultamento dos nossos antepassados. De acordo com Adele

2 Outros registros antropológicos que podem ser encontrados para estudo das civilizações passadas são: esculturas em pedra, desenhos e inscrições rupestres nas paredes das cavernas, ossos e outros objetos fossilizados.

3 Entenda-se neste ponto que os conceitos de beleza são extremamente mutáveis, variando conforme épocas e culturas distintas.

4 Usaremos a palavra recipiente quando nos referirmos aos potes cerâmicos, pois assim também estaremos fazendo uma alusão direta às obras da autora Mulheres recipientes. 
Getty (1997, p.8), há na região de Le Roc ${ }^{5}$ lajes de pedra com relevos de figuras femininas apoiadas na terra. Estas imagens poderiam indicar o culto à Mãe Terra, pois é possível acreditar que as grutas fossem relacionadas simbolicamente a um útero ou mesmo tumbas da humanidade, logo, eram considerados locais sagrados. Neste mesmo ponto, a autora ainda afirma que a experiência de adentrar numa gruta, seria equivalente a sentir múltiplas emoções simultaneamente, como certo receio devido ao fato de compararmos o silêncio e a escuridão com nossa ancestralidade e com a sensação imemorial de estarmos dentro de outro corpo.

Existe uma curiosidade acerca do manuseio e feitio da cerâmica em toda a América: o fato de ser esta uma atividade especialmente feita por mulheres. Segundo Lévi-Strauss somente em algumas poucas comunidades tribais, a cerâmica era feita por homens. Ao descrever um mito dos Hidatsa, índios do alto do Missouri, de língua soiux, o autor mostra como o ato de fazer a cerâmica era uma ocupação sagrada, misteriosa e ligada ao universo feminino. Apenas as mulheres que haviam herdado o direito de poder praticá-la através de outras mulheres, suas próprias ancestrais, até que se chegasse à ancestralidade mais longínqua que teria recebido das Serpentes esse direito, já que o mito dizia que unicamente as Serpentes podiam fazer cerâmica. Além disso, havia uma série de restrições durante a feitura da cerâmica: ninguém poderia se aproximar da ceramista enquanto ela celebrava os cânticos religiosos e nem tão pouco ter acesso a sua casa.

Conhecida também como Mãe Terra, Avó da argila, Senhora da argila e dos potes de barro, a padroeira da cerâmica era considerada uma benfeitora já que a humanidade lhe devia não apenas a matéria-prima, mas as técnicas e a arte de decorar potes. Alguns mitos considerados por Lévis-Strauss, em contrapartida revelavam uma faceta temperamental ciumenta e rabugenta (Lévi-Strauss, 1985, p.40). A cerâmica era, portanto, uma atividade quase que res-

5 Le Roc é uma comuna francesa na região administrativa de Midi-Pyrénées, no departamento de Lot. 8. "Caso raro, mas não único na América do Sul, entre os Urubu, Tupi do Maranhão, a cerâmica é uma tarefa masculina. [...] Sem pretender remontar às origens, o fato é que, na América, o mais frequente é a cerâmica ser uma tarefa feminina." (Lévi-Strauss, 1985, p.38). 
trita às mulheres, na maioria das vezes de caráter sagrado e envolta em uma série de especificidades, cuidados e proibições. Paralelo a tudo isso havia sempre inúmeros mitos que remetiam às explicações sobre a origem e a função da argila entre os humanos. Para ilustrar esse fato, Lévi-Strauss nos mostra uma das diversas origens mitológicas da argila na terra e a sua clara ligação com as mulheres através de um mito Jivaro. ${ }^{6}$ Para esse povo, a palavra nui significa argila e, no mito da origem da cerâmica, que ocorre junto ao mito da criação do mundo "[...] a abóboda celeste é uma grande tigela azul de cerâmica. Foi com barro que o Criador fez Nantu, a Lua, que irá se casar com Sol, e é com argila que ela modela um filho, em seguida destruído pelo Engolevento." Esse filho recebe o nome de Nuhi (cf. nui, "argila") e após sua morte, seu corpo transformou-se na terra em que hoje vivemos. $\mathrm{O}$ autor continua a descrição deste mesmo mito, afirmando que Sol e Lua tiveram como descendentes o Preguiça, o Boto, o Caititu e a Mandioca, uma filha e depois disso ficaram estéreis. A mãe de ambos lhes entregou dois ovos: um se perdeu e do outro nasceu Mika, uma menina. Mais tarde Mika se casaria com Unushi, seu irmão Preguiça. Mika além de ser a padroeira da cerâmica, é também o nome ritualístico dos grandes vasos cerâmicos em que se coloca a chicha ${ }^{7}$ a ser consumida nas cerimônias. Lévi-Strauss cita que o antropólogo Karsten destacou a proximidade fonética das palavras mulher "nua" e cerâmica "nui". "Já apontei alhures" - diz ele - "para a interessante conexão entre a mulher, de quem a cerâmica é uma das atribuições, e a terra ou argila que ela utiliza. No pensamento dos índios, o vaso de argila é uma mulher." O autor ainda ressalta que é tarefa da mulher fa-

6 Os Jivaro são uma tribo localizada na fronteira entre o Equador e o Peru, nas encostas orientais dos Andes e em seu sopé. São conhecidos pela antiga arte de "encolher cabeças", arte atualmente não mais praticada (Lévi-Strauss, 1985, p.23).

7 Chicha. S.f.1. bebida alcoólica, geralmente feita com mandioca, mel e água, mas também com milho ou frutas fermentados.[...] 'espécie de cerveja da América do Sul e da América Central feita principalmente de milho fermentado', em muitos países da América Latina; no México, 'aguardente de cana', prov. de chichah (co-pah) [...] (Cf. Houaiss, 2001. p.699). 
bricar e utilizar os recipientes cerâmicos, "[...] pois a argila de que são feitos é fêmea, como a terra - em outras palavras, tem alma de mulher." (Lévi-Strauss, 1985, p.32 e 33)

Para o povo Jivaro e para muitas outras sociedades tribais, a relação entre a matéria argilosa e a mulher era evidente e facilmente explicada através dos mitos. Entre as possíveis explicações para entendermos essa relação mítica entre a mulher e a cerâmica, uma delas seria o fato de ambas passarem por transformações: a mulher todos os meses transforma-se ao menstruar e, principalmente, ao engravidar; a cerâmica tem sua matéria transformada através do fogo e, de maleável e moldável, torna-se rígida e resistente até mesmo ao próprio fogo. Assim como no ventre das mulheres há uma espécie de recipiente gerador e mantenedor de vidas, os recipientes cerâmicos são usados para manter e preparar os alimentos. Ambas as formas são essencialmente semelhantes por serem convexas ou côncavas: os recipientes cerâmicos eram essencialmente feitos em formato de receptáculo, assim como o órgão reprodutor feminino. Ao redor da mitologia sobre a origem da cerâmica, também existiam rigorosos métodos de colheita e preparo do barro pelas mulheres. "Em todas as informações relativas à arte da cerâmica na América do Sul, fica evidente que ela é objeto de cuidados, preceitos e proibições múltiplas." Lévis-Strauss continua dizendo que os Yucararé, uma tribo que vive a beira sul dos Andes, também rodeavam as práticas da cerâmica com uma série de precauções rigorosas. "As mulheres, que são as únicas a praticar essa arte, iam solenemente buscar a argila durante o período do ano que não era dedicado às colheitas." Elas escondiam-se num lugar afastado para construir seu abrigo e celebrar seus ritos, um lugar em que ninguém as visse e que as protegesse dos trovões, pois elas acreditavam piamente que qualquer ruído pudesse rachar os potes durante a queima (Lévi-Strauss, 1985, p.34 e 35)

Desta forma as mulheres, apesar de serem as únicas a manipular a argila, eram submetidas à ela, simultaneamente. Mitos do povo Tacana, na Bolívia, ao sopé do Andes, reafirmam esse fato ao contar "que a avó da argila ensinou as mulheres a modelar vasos de terra, cozê-los e torná-los resistentes." O mito continua descrevendo como a divindade era exigente, pois "insistia para que as mulheres lhe fizes- 
sem companhia, convidava-as para vir à sua casa, e, para prendê-las junto a si provocava o deslizamento da terra que cobria os leitos de argila, enterrando-as." Na Colômbia, "os Tainimuka ou Ofaina acreditam que a Terra Namatu, a mulher primordial, instituiu a arte da cerâmica. Ela é a senhora dos potes, que não podem ser fabricados sem sua permissão." Para o feitio de determinadas panelas de barro (as de fazer beiju) existe uma série de precauções: o preparo é feito em um local especifico da aldeia; as mulheres menstruadas e grávidas são proibidas de se aproximarem da argila, por serem "quentes demais"; as crianças são afastadas da queima se ela ocorrer de dia; ninguém pode entrar molhado na aldeia e nem a ceramista pode tomar banho, pois as panelas são sensíveis ao frio. Cabe à ceramista fazer abstinência sexual e manter o cabelo arrumado para que não caia nenhum fio em sua obra. Para se coser as panelas, eram feitos três suportes de barro (que representam os três pilares cósmicos) bem ao centro da casa coletiva. O centro da casa para eles é o centro do mundo e, se por acaso esse pilares "forem abalados pela cobra enrolada em torno deles, a estabilidade do mundo em que vivem os humanos, e também dos outros mundos, corre perigo." (Lévi-Strauss, 1985, p.39 e 40)

Lévi-Strauss, ainda no livro A oleira ciumenta, nos conta que as mulheres da tribo Jivaro não deveriam apenas saber fazer cerâmica, mas saber fazê-la de modo satisfatório: "Para merecer um marido bom caçador, uma mulher tem de saber fabricar uma louça de qualidade, para cozinhar e servir a caça. Mulheres incapazes de fazer cerâmica seriam, realmente, criaturas malditas." (Lévi-Strauss, 1985, p.37) Também nesta citação fica evidente a relação dos papéis femininos e masculinos na aldeia: cabia à mulher o poder de gerar os frutos humanos, alimentícios (plantio e colheita) e cerâmicos. Eram as mulheres as responsáveis pelo plantio e colheita da lavoura, pela coleta, feitura e queima do barro, assim como pela gestação e o cuidado para com os filhos. Aos homens cabiam todos os esforços que exigissem a locomoção para fora da aldeia, seja a caça, a pesca, as lutas, as armas e tudo o que despendesse da força física.

A diferenciação física entre homens e mulheres era evidente para os nossos ancestrais e este era, até então, o único modo de se 
explicar a dicotomia entre ambos. Capazes de gerar e manter novas vidas, as mulheres detinham certa magia e poder sobre os homens: o mistério da procriação as envolvia. Essa capacidade criadora era algo não só inexplicável, como também de extrema importância, por ser o modo de perpetuar a espécie.

E essas primeiras sociedades estruturadas e mais estáveis, pelo fato de estarem aprendendo a dominar técnicas da agricultura e pastoreio, tinham em comum o culto à Grande Deusa, também conhecida por Mãe Terra ou Pachamama. ${ }^{8}$ A esse respeito a professora Lalada Dalglish explana, em poucas palavra, essa relação:

Os vários povos primitivos que deixaram de ser nômades e passaram a praticar a agricultura desenvolveram técnicas artesanais com fins utilitários e ritualísticos. A terra, de onde brota a água e alimento, passou a ser associada a fertilidade da mulher, que, por sua vez, também podia gerar filhos; nasce aí o culto às "deusas da fertilidade", associado ao ciclo das colheitas. Em todas as culturas por onde apareceram, estas deusas votivas adquiriram diferentes nomes, mas possuíam as mesmas intenções votivas associadas à fertilidade. (Dalglish, 2006, p.22)

As comunidades tribais dependiam sobremaneira deste papel reprodutor, gerador, agregador, mantenedor das mulheres, para continuarem vivos. Essa capacidade criadora era algo não só inexplicável, como também de extrema importância, visto que este era o único modo de perpetuar a espécie. Diz Joseph Campbell que até recentemente, papel social da mulher era o de garantir a preserva-

8 Nas Américas pré-colombianas, "Pacha significa tempo na língua Kolla, mas seu significado engloba o universo, o mundo, o tempo, o lugar, enquanto que Mama é mãe. A Pachamama é adorada em suas várias formas: os campos arados, as montanhas como seios e os rios caudalosos como seu leite. Refere-se, também, ao tempo que cura as dores, que distribui as estações e que fecunda a Terra." Sua popularidade era imensa, principalmente para as populações rurais isoladas nas montanhas, que dependiam exclusivamente da natureza para subsistência". Disponível em: http://rosanevolpatto.trd.br/Pachamama. html. Acesso em: 28/09/08 às 20:12. 
ção da nossa espécie - a relação do homem com essa função era quase inexistente. "E, à maneira dos homens primitivos, a função do macho nessa sociedade é preparar e preservar um ambiente no qual a fêmea possa gerar os espécimes futuros." Fica evidente a diferenciação dos papéis de cada um. "E seus corpos são distintamente adequados para desempenhá-los.” (Campbell, 1990b, p.8-9) A importância da mulher nas sociedades ancestrais era também ressaltada pela idéia de associação do nascimento dos frutos (na agricultura) com o nascimento dos filhos (na procriação). Essas sociedades mais estruturadas e estáveis, pelo fato de estarem aprendendo a dominar técnicas de agricultura e pastoreio, tinham em comum o culto à Grande Deusa. Campbell compara o poder de procriação da mulher na era pagã, ao mesmo poder gerador existente no reino vegetal: "A mulher dá a luz, assim, como na terra se originam as plantas. A mãe alimenta como o fazem as plantas. Assim, a magia da mãe e a magia da terra são a mesma coisa. Relacionam-se." O autor afirma que a "personificação da energia que dá origem às formas e as alimenta é essencialmente feminina. A Deusa é o próprio universo. Tudo quanto você vê, tudo aquilo em que possa pensar, é produto da Deusa." (Campbell, 1990b, p.177)

As mulheres não eram responsabilizadas por sua gravidez em povos que mantinham tais crenças, ou seja, de que a gravidez não dependia da relação sexual humana. Simone de Beauvoir (1987) afirma que nesse período era desconhecida a participação do pai na procriação, pois apenas a mãe gerava em seu ventre a criança e, depois de parida, era ela quem amamentava e nutria os filhos, garantindo assim, a perpetuação do clã. "Com, efeito, os povos primitivos não acreditam que o homem tenha alguma importância na reprodução" alguns, inclusive, acreditavam que o papel do homem na relação sexual era apenas o de romper o hímen para dilatar a passagem ao verdadeiro agente semeador: os raios lunares (Beauvoir, 1987, apud Santos). Se a mulher engravidasse era sempre por um motivo externo a ela, talvez pela ação da lua, por ter ingerido determinado alimento, ou mesmo por algo místico. Em sociedades ancestrais como essas que estamos considerando, não existia nenhuma restrição à 
relação sexual, de maneira que a conexão entre a gravidez e o sexo poderia nem ser relacionada. E como a duração exata da gravidez foi conhecida apenas em um estágio de cultura mais recente, era plausível que nossos antecessores não relacionassem esses fatos. Para Getty (1997) "não existiam filhos ilegítimos nem mulheres 'marcadas', porque não se atribuía valor nenhum à paternidade. 'O filho de um é filho de todos', como dizem os Ibos da África em certos cânticos."

Deste modo, não é difícil entender como e porque as culturas ancestrais valorizavam e cultuavam amplamente o universo feminino. Eram desconhecidos tanto os processos de germinação da semente quanto a gestação na mulher, logo, não seria estranho que se atribuíssem às mulheres poderes místicos e sagrados, também ligados a terra.

\section{A Grande Mãe, Pachamama: um símbolo da fertilidade}

"Santa deusa Tellus,

Mãe da Natureza Viva, alimento da vida;

Tu dás em eterna lealdade e, quando a vida nos deixa, encontramos refúgio em Ti. Tudo quanto repartires a teu ventre retorna.

Justamente Te chamam Mãe dos Deuses, porque com Tua lealdade conquistaste o poder dos Deuses.

Na verdade és também Mãe dos povos e dos Deuses Ninguém pode florescer nem existir sem Ti; Tu és poderosa; dos Deuses

Rainha e Deusa.

A Ti e ao Teu poder invoco, oh, Deusa; Tu podes conceder-me tudo quanto pedir, e em troca prestarTe-ei, oh, Deusa, os meus mais sinceros agradecimentos."

Loa, século II

Hoje podemos saber, através das incontáveis estatuetas e imagens sagradas com formas femininas, como nossos antepassados 
veneravam a vida, focando particularmente o poder da Grande Mãe. Apesar de a Deusa ser apresentada sob diversas maneiras, diferindo-se no formato, nomenclatura ou materiais, sua conotação simbólica era sempre mantida: a responsabilidade pela vida no mundo. A Deusa era quem criava, nutria, sustentava e restabelecia a vida. As chamadas "vênus esteatopígicas" foram encontradas em diversas civilizações e épocas distintas, ${ }^{10}$ juntamente com outros tantos artefatos dos períodos Paleolítico e Neolítico. ${ }^{11}$ Essas imagens podem ser consideradas a representação dos nossos mais antigos impulsos criadores dos mitos.

Na América Latina, especialmente no Peru, Bolívia e norte da Argentina, a Deusa ou Grande Mãe era chamada por Pachamama, literalmente, Terra Mãe. Iconograficamente, a Pachamama, assim como a Grande Deusa no continente europeu, aparece de diversas formas: como grávida, é a deusa da fertilidade; como uma velha índia acompanhada de um cão feroz, é a Senhora da Terra. De tão forte que era a crença nesta divindade, mesmo após a colonização

9 "Estatuetas femininas dotadas de grandes seios e nádegas, a sugerir, provavelmente, o culto à fertilidade.[...] Todas elas seguem um esquema semelhanteo de um losango, em que a cabeça e os pés, trabalhados sumariamente, ocupam as extremidades; no centro, os seios, a bacia e o ventre aparecem hipertrofiados" (Cunha, 2003. p. 71).

10 Estes artefatos foram encontrados em toda Europa e nas Américas, no período denominado de "pré-colombiano", ou seja, antes da chegada de Colombo (idem, ibidem) .

11 A chamada Idade da Pedra da pré-história compreende os períodos Paleolítico, Mesolítico, Neolítico e Calcolítico. O período Paleolítico Superior se estendeu até $10.000 \mathrm{aC}$ e foi a época que o chamado Homo sapiens começou a manipular e modificar objetos, especialmente as pedras. Cada tribo ou comunidade criou 'estilos' na confecção de utensílios diferenciando-se. Graças à essas peculiaridades de manufatura, foi possível distinguir quatro eras: a Aurinaciana (30.000), a Gravetiana (25.000-20.000), a Solutriana (20.000-15.000) e a Magdaleniana (15.000-10.000). O período Neolítico é caracterizado pelo surgimento das primeiras edificações arquitetônicas monumentais com uma função religiosa, especialmente em Eridu ou Çatal Hüyük, na Turquia. Esse período também é caracterizado pela expansão da agricultura sedentária, domesticação de animais e criação de gado na Europa (ibidem, p. 71 - 72) 
européia nas Américas, não apenas a representação, como, também, todo seu caráter simbólico, foi incorporado à imagem da Virgem Maria, mãe de Deus.

O poder que a Deusa Mãe exercia em nossos ancestrais era imenso; refletia a ordem social e o papel privilegiado da mulher como procriadora, já que a reprodução era um grande mistério. Esse período foi denominado por alguns especialistas como matriarcado, pois a importância da mulher era tamanha que o núcleo familiar e social girava em torno dela. O mistério da gestação estava diretamente ligado ao poder misterioso do feminino. Assim como uma consequência da observação dos ciclos da natureza e de toda a magia que envolvia a criação das espécies, nossos antepassados começaram a cultuar a Deusa Mãe que era geradora de vida, a Grande Mãe de todos os seres viventes. "São-lhe prestadas honras pela sua qualidade de dar e manter a vida: do seu ventre surge o grande mistério, e tudo volta a ela [...]” (Getty,1997, p.5)

Foi através dos infindáveis mitos das mais diversas culturas que pudemos constatar o poder e o papel do feminino na estruturação do mundo. De acordo com Senna (2007), a veneração à Deusa cobriu amplo território e período da história da humanidade, cerca de 50.000 anos. Estudos antropológicos constatam esta veneração desde o Paleolítico Superior europeu, o Neolítico no Oriente Médio, a idade do bronze nos vales dos grandes rios - Nilo, Eufrates, Tigre, Ganges - também ocorrendo no período formativo da América pré-colombiana. É interessante notar que, mesmo em comunidades tão distantes e em períodos tão longínquos, havia um fio condutor, um "cordão umbilical” que ligava a Grande Deusa Mãe com todos os seus filhos. As representações celebrando o corpo fértil da mulher apareciam não apenas nas pinturas e estatuetas, mas também em baixo relevos, amuletos ou possíveis objetos de veneração. Eram caracterizadas, principalmente, pela robustez de um estágio avançado de gravidez, com "caracteres sexuais, nádegas, ventre e seios, com excesso de volume e polidez, proclamando a admiração e o respeito dos primitivos diante dessas figuras portadoras do bem mais precioso - a vida.” (Senna, 2007, p.56). 
Segundo estudos de W. K. Gregory encontra-se entre 40.000 e 30.000 a.C., pela Europa e parte do Sudeste da Ásia e em alguns outros lugares, o homo sapiens tardio (o homem de Cro-Magnon), que é tido como o responsável pela criação destas estatuetas pequenas - com cerca de 3 a $22 \mathrm{~cm}$ - denominadas, pelos pesquisadores do século XIX, Vênus (Campbell, 1990a). Conforme o historiador Siegfried Giedion, a denominação poderia indicar um suposto significado erótico, uma vez que a deusa seria a versão latina da deusa grega Afrodite - que simboliza o amor e a beleza. Giedion também chegou a citar que alguns pesquisadores defenderam a idéia de que tais figuras não eram de modo algum imagens que representassem sensualidade, mas sim que essas estatuetas de mulheres maduras de seios pesados, ventre protuberante e nádegas exageradas eram representações simbólicas da fertilidade (Giedion, 1999); o que não anula, a nosso ver, suposição de que poderiam ser também um estímulo erótico, principalmente, se considerarmos o sentido de erotismo como voltado para a vida, como o conceito freudiano de libido.

A partir de 35.000 a.C., desde a cultura aurinhacense do Paleolítico até ao Neolítico agrícola, começaram a ser modeladas pequenas estátuas da Deusa com barro e cinza e depois cozidas, ou talhadas em osso, chifre ou marfim, na Espanha, França, Europa oriental, Rússia, Mediterrâneo e Oriente Médio. O arqueólogos têm vindo a descobrir numerosos amuletos que representam certos aspectos da Deusa, os peitos ou a vulva. Estas estátuas, juntamente com as imagens esteatopígicas e as figuras alargadas com cabeça de ave não constituem de modo nenhum uma forma de pornografia, como sugeriam muitos estudiosos. (Getty, 1997, p.7 e 8)

De acordo com Getty, estas representações foram encontradas numa vasta região, que ia da França à Sibéria, e mantinham uma repetição quanto ao formato e ao tema: "representam a capacidade corporal da mulher para dar a luz, sangrar e curar-se em cada lua, para nutrir e amamentar e finalmente morrer e renascer." A autora 
ainda afirma que essas oferendas votivas eram como uma ajuda mágica a todos os "indivíduos e à comunidade para garantir bom parto, leite e alimento abundantes, ou possivelmente fizessem parte de um ritual de trânsito para a feminilidade." (Getty, 1997, p.8)

Muitos dos locais que foram descobertos por estudiosos, como as cavernas ou em volumosas rochas, os vestígios destes "homens das cavernas" se apresentaram sob forma de grandiosas pinturas na parede ou mesmo objetos calcários. Essas imagens, por se localizarem nas partes mais profundas das cavernas, faziam parte de uma espécie de ritual mágico cujo propósito, muito provavelmente, era o de assegurar uma boa caça. "Aparentemente, para os homens do Paleolítico não havia uma distinção muito nítida entre imagem e realidade" (Janson, 1996, p.14-15).

\section{A mulher e a lua: representações e evocações}

"São seus atributos: a lua, indicando o ciclo menstrual e as estações do ano, a cornucópia repleta de flores, frutos e sementes, simbolo da fecundidade do solo, a serpente que sinaliza a ligação entre os dois mundos opostos, a espiral como símbolo da vida que se renova, que é cíclica, a concha e o triângulo, em alusão direta à vagina."

Nádia da Cruz Senna

Amuletos ou estatuetas representavam a Grande Mãe, ou então, poderiam ser consideradas como a própria Deusa em si. O que se pode confabular é que, por sua pequenez e portabilidade, essas estatuetas fossem carregadas junto com as pessoas para que, assim, o poder da Deusa pudesse ser evocado em qualquer momento ou situação. As vênus portáteis da era paleolítica tinham apenas algumas polegadas de altura e, segundo Campbell (1990a, p.1718), foram encontradas, pelo menos duzentas, ao longo da costa atlântica, contudo este sítio arqueológico vai da França à Espanha, até a fronteira com a China. Na França, em uma prateleira rocho- 
sa, denominada Laussel, foi encontrada uma figura importante e sugestiva, uma pequena vênus que segura, na mão direita erguida, um chifre de bisão com treze traços verticais, que correspondem ao número de noites entre o primeiro crescente e a lua cheia. De acordo com o mitólogo seria o reconhecimento da equivalência dos ciclos menstrual e lunar. A Mãe da Vida não tem rosto, só quadris e seios volumosos, só dádiva maternal. Guardadas no que foram moradas, e não em grandes cavernas, com as pernas terminando em volume cônico, essas pequenas vênus foram feitas para adaptar-se aos locais de culto, apoiadas em buracos no chão. A outra mão sobre a barriga seria um indício das correlações entre os ritmos celestial e terreno da vida. No baixo relevo em pedra da Vênus de Laussel, é possível perceber, pelo modo como ela foi esculpida, a afirmação de Campbell sobre a ligação do ciclo menstrual da mulher com o ciclo ou fases da lua. ${ }^{12}$ "No mundo inteiro a Lua é associada ao eterno feminino, pois o ciclo mensal do nosso satélite lembra os ritmos da feminilidade" (Getty, 1997, p.11).

No livro The once and future goddess: a symbol for our time, a escritora e pesquisadora Elinor Gadon nos conta, também, sobre essa relação do sangue menstrual com o ciclo lunar: "O sangue periódico das mulheres era um evento cósmico, como os ciclos da lua e das marés baixas e altas. Nós esquecemos que as mulheres eram as condutoras do sagrado mistério da vida e da morte" (Gadon, 1989, p.2, tradução nossa).

Deste modo, para esses povos, as mulheres e a lua eram originárias da mesma natureza, na medida em que ambas tinham a capacidade de 'intumescer-se' e de seus ciclos terem a mesma duração, ou seja, uma evidência direta da sintonia entre o corpo das mulheres e o corpo celeste. "A palavra para designar menstruação e a pala-

12 O tempo do ciclo menstrual das mulheres é similar ao período da lua em cada um dos seus quatro estágios. Assim como a lua tem suas fases, mudanças de formato (de cor, inclusive), as mulheres também passam por ciclos mensais que transformam seu corpo. Ventre e seios incham e ficam doloridos e o sinal externo de que a mulher está nessa fase é a mancha vermelha do sangue menstrual. 
vra para designar lua são iguais ou intimamente ligadas em várias línguas, fato que mostra a estreita conexão que é sentida entre as mulheres e a lua" (Harding, 1985, p.52).

Como Senhora das mulheres, a lua era possuidora do poder divino da fertilidade, diretamente ligada às mulheres. Nesse modo de pensar, a lua tinha um poder benéfico e indispensável no crescimento e formação das coisas, desde a germinação das sementes na terra, como na concepção dos seres humanos e na procriação animal. Todo o mistério desta força geradora estava diretamente ligado à lua, aos ciclos lunares e, consequentemente à noite, em contraposição com o calor e a luminosidade do sol durante o dia.

Para muitos povos ancestrais, o sol se configurava como uma força hostil ao desenvolvimento da vegetação e também à reprodução das espécies. A luz da lua faria, então, um contraponto com a luz hostil do sol. Cabe ressaltar que este poder atribuído à lua é uma representação simbólica da fertilidade, já que, muito provavelmente, para esses povos ancestrais, o mito e sua simbologia explicavam a própria realidade. A lua para eles era possuidora e doadora da fertilidade, ou seja, os seres vivos apenas poderiam ser gerados e se desenvolverem sob a influência da energia lunar, conforme explica a autora Harding (1985). Esse modo de conceituar a fertilidade, pode nos soar um tanto absurdo, uma vez que, atualmente, sabemos exatamente como os seres vivos são gerados: as funções dos órgãos reprodutores, os processos de fecundação e desenvolvimento do feto, o tempo real da gestação e como se evita uma gestação. ${ }^{13}$ Assim, a lua em seu estágio crescente estaria diretamente ligada ao desenvolvimento e à fartura de bens e ao aumento e desenvolvimento da prole. Sua força, muito provavelmente, era invocada para o crescimento e expansão das plantações, rebanhos e da própria família. Vale lembrar que uma família grande, com muitos filhos e filhas, representava, aos que cultivavam a terra e dela dependiam,

13 Atualmente esses são assuntos obrigatórios nos currículos da disciplina de Biologia, no Ensino Fundamental e Ensino Médio, nas escolas públicas e particulares do país. 
a garantia de segurança contra a falta de alimento e o amparo na velhice. No sul da Itália, a lua até hoje é usada como amuleto na hora do parto. "As mulheres católicas da Itália diziam que a Mãe que é a 'Lua-da-nossa-Igreja' é a 'Mãe Maria'. Ao dizerem isso, elas podem ou não olhar a lua no céu e fazer reverência" (Harding, 1985, p.53)

A Vênus de Lespugue, estatueta encontrada próxima a Lespugue, mede aproximadamente $15 \mathrm{~cm}$. Apesar de estar danificada, seu acabamento é mais elaborado nas formas e nos detalhes. Como de costume, essa Vênus não possuía traços no rosto, apenas as formas exageradamente enfatizadas dos seios, ventre, quadris e nádegas. Os membros inferiores são delgados e finalizam em uma ponta. Por não terem uma base para se equilibrar em um plano reto, ou seja, seus pés e pernas eram juntos e pontiagudos, acredita-se que eram feitas para serem fincadas no solo ou mesmo colocadas em relicários de pequenos altares domésticos (Câmara, 1999). Campbell ao descrever a Vênus de Lespugue, nos revela detalhes singelos, porém deveras interessantes, sobre o formato de seu corpo e o seu encantamento: "Toda a magia da mulher está contida dentro de um círculo. Os seios e os quadris são puxados para baixo; temos então o elegante movimento ascendente do tórax para a cabeça, e depois os pés os quais a colocaram num pequeno relicário”. A pequena peça se eleva na parte de cima em um "elegante movimento ascendente", tornando-se mais reduzida e afunilada na parte inferior (Campbell, 1990a, p.19). Nela, podemos perceber traços extremamente estilizados na representação do corpo feminino. Seu formato faz uma alusão ao círculo, ao curvilíneo, possivelmente, por ser uma representação simbólica da fertilidade: os seios, ventre (útero), glúteos arredondados - ou seja, "toda a magia da mulher está contida no círculo" como afirmou Campbell. É possível que esses objetos não tendessem a um realismo simplista, apenas demonstrariam e destacariam alguns valores atrelados a uma realidade cotidiana: a gestação. Portanto, o corpo curvilíneo da mulher, especialmente, no caso da mulher grávida. Talvez porque as mulheres deste período engravidavam ininterruptamente, tendo um filho após o outro. 
A Vênus de Willendorf é uma das mais conhecidas estatuetas deste período. Suas formas arredondadas e sinuosas foram esculpidas em calcário colorido, numa cor aproximada ao ocre avermelhado. Nela, podemos notar, claramente, características essenciais de uma gestação: as formas dos seios, coxas, ventre e nádegas bem proeminentes. Vemos também como é proeminente o umbigo e o púbis, os braços dobram-se sobre os seios, aparecendo como uma estreita linha, as feições do rosto estão completamente suprimidas e a cabeça foi adornada por uma série de pequenas protuberâncias que podem sugerir penteado trançado ou cabelo muito encaracolado. Seus pés não foram esculpidos, assim como não existe referência de suporte ou pedestal que sustentasse a figura na vertical. Pressupõe-se que a estatueta era provavelmente usada como um amuleto de âmbito familiar, justamente pela facilidade de carregar uma peça tão pequena (Senna, 2007).

Além da arte das cavernas feita em grandes proporções, os homens do Paleolítico também criaram pequenas esculturas do tamanho de uma mão, utilizando-se de osso, chifre ou pedra cortados com talhadeiras rudimentares. Essas esculturas também parecem dever sua origem a semelhanças casuais. Num estágio mais primitivo, os homens do Paleolítico tinham se alegrado ao coletarem seixos em cujo formato natural viam uma qualidade representacional "mágica"; as peças mais minuciosamente trabalhadas dos tempos posteriores ainda refletem essa atitude. Assim, a chamada Vênus de Willendorf na Áustria, uma das inúmeras estatuetas da fertilidade, tem uma forma arredondada e bulbiforme que pode sugerir um "seixo sagrado" oval. (Janson, 1996, p.16 e 17)

A deusa entronada, famosa estatueta datada na metade do século VI a.C., é originaria da Turquia, Çatal Höyük. A figura feminina está sentada no trono, acompanhada de dois felinos um de cada lado, dispostos a simularem os braços da poltrona. Pela robustez de seu corpo que enfatiza suas características sexuais, é provável que esta estátua esteja sugerindo uma gravidez. Por suas características 
formais, ela foi interpretada como um símbolo da fertilidade e fecundidade, direcionando uma leitura sobre os possíveis comportamentos religiosos do período Neolítico.

Outro exemplo claro de culto ao feminino é a estatueta egípcia Deusa-Pássaro funerária, que data de 3500 a 3100 a.C. Com formas bem simplificadas, sugere quase uma abstração do corpo da mulher. Sua cabeça é pontiaguda, lembrando um bico de pássaro e seu pescoço é longo e proporcionalmente maior que a cabeça. Os braços estão levantados, formando uma delicada curvatura com as mãos os dedos estão cuidadosamente entalhados em ambos os lados. Seu torso tem formato triangular e é ligeiramente inclinado para trás, os seios são pendentes e a cintura é estreita, formando uma sinuosa curva que segue pelos quadris e nádegas arredondados. Como na maioria das vezes, essas estatuetas não tinham pés modelados, esta parte do corpo (o que poderia ser considerado uma saia) foi pintada de branco. A figura inteira foi originalmente coberta com vermelho ocre. Sua postura sugere que a figura feminina esteja em uma espécie de dança ou em luto ${ }^{14}$ ou, até mesmo, que talvez esteja associada a algum um ritual de ressurreição (Phaidon, 2007, p.19 e 39).

Qual seria a natureza dos ritos e símbolos pré-históricos? Alguns autores pensam que essa função ultrapassaria uma mera necessidade de manifestar a fertilidade. ${ }^{15}$ Suas observações apontam para uma relação muito mais integradora com a natureza, com o mundo como totalidade, onde todos os seres vivos e inanimados eram sagrados. ${ }^{16}$ Para eles, a natureza é una, sem a distinção de superioridade do humano. E, sem a dicotomia entre espiritualidade e natureza, religiosidade e profano, a arte também estava inserida em um contexto cotidiano e era, portanto, um reflexo desta visão de

14 Do inglês "mourning figure" que pode ser traduzido como figura de luto ou figura de lamentação.

15 Marija Gimbutas, Alexander Marshack, Riane Eisler, entre outros (Senna, 2007, p.57).

16 Muito similar à visão de povos indígenas que não distinguem hierarquicamente as plantas e os animais, como nós ocidentais o fazemos, separando em classes, espécies, raças etc. 
mundo - visão diametralmente oposta a da cultura judaico-cristã. Era um modo de enxergar a vida, celebrando não apenas a sexualidade como fonte de prazer, como também divinizando a mulher como fonte de vida. Segundo esses autores, tais sociedades baseavam-se muito mais em relações de parceria, do que de dominação, enfatizando o cálice - símbolo feminino - e não a espada - símbolo masculino (Senna, 2007, p.57)

Parece coerente cogitar a possibilidade de que ao observarem os seus próprios ciclos e o crescimento estacional das plantas, "fossem as mulheres as primeiras a tomarem consciência do caráter periódico da natureza e o registro destes ritmos, internos e externos."(Getty, 1997, p.8). Talvez isso possa ter contribuído para que fossem desenvolvidos os primórdios da ciência e da religião. Foram descobertos restos mortais dos homens de Neanderthal e o de Cromagnon, dispostos de modo a sugerir um rito cerimonial um outro indício d a crença de vida após a morte. O pigmento ocre vermelho foi encontrado em várias ornamentações de efígies da Deusa (como no caso da Vênus de Willendorf e da Deusa-Pássaro funerária) e outros objetos. Indubitavelmente a cor vermelha está ligada ao sangue e, simbolicamente, representa a vida ou a morte em um estágio primário. "O ocre vermelho representa as qualidades reafirmadoras da vida do sangue, a prima matéria. As pessoas só sangram enquanto vivas e as mulheres sangram todos os meses e no parto [...]" (Getty, 1997, 8). A relação entre sangue e vida era algo palpável, visível e presente em todos os animais de sangue quente. ${ }^{17}$ Assim, a cor vermelha representa a cor da vida, não só de modo simbólico (nas pinturas rupestres ou mesmo nas representações de divindades), mas principalmente de modo vívido: na menstruação feminina, no parto, em ferimentos ou em cortes que

17 Todos os mamíferos e todas as aves (com algumas exceções) são considerados animais de sangue quente devido à necessidade de manterem o corpo em uma temperatura constante (gerando calor em ambientes frios ou esfriando-se quando em locais mais quentes). Os animais com sangue frio não necessitam manter a temperatura estável do seu corpo, variando-a conforme a temperatura ambiente - répteis, insetos, aracnídeos, anfíbios e peixes. 
mostrem o interior de um corpo. O fato é que nossos ancestrais entendiam que a vida no planeta era formada por ciclos, por estações, por fases, com começo, meio e fim. O entendimento desse ciclo, parte do princípio de que vida e morte são complementares. A compreensão do que deve ser o processo natural das coisas, o ciclo de renovação, onde uma geração é substituída por outra, enfatiza a questão da dualidade convergente. Para se ter vida é necessário que haja a morte. "Ó Deusa Mãe, assim como a lua renasceu, possa eu também, meu corpo mortal, ser devolvido à fonte" (Campbell, 1990, p.53). Muitos mitos procuram explicar, cada um a seu modo, as diferenças entre a vida e a morte, entre o dia e a noite, entre homens e mulheres, entre os opostos complementares.

Ao observar e interferir na natureza, os seres humanos começaram a mudar seu modus vivendi. Talvez tenha sido o desenvolvimento da agricultura que ocasionou transformações consideráveis na sociedade. "Sem dúvida, as consequências da agricultura primitiva sobre a comunidade humana merecem o título de 'revolução neolítica', e é opinião geralmente aceita de que foram as mulheres que iniciaram tal revolução.” (Getty, 1997, p.15) Ocorre que com este tipo de desenvolvimento, as comunidades nômades passaram a se estabelecer em locais fixos, começaram a crescer demasiadamente, necessitando de uma demanda maior de alimento. Com períodos de secas e enchentes, esgotamento do solo, pragas, a humanidade percebeu a necessidade de armazenar a produção excedente. Essa transformação lenta que a humanidade passou, saindo da caverna e construindo o que seriam as futuras aldeias, a crença na Senhora dos Animais, na Grande Mãe, também modificou-se.

Também foi no Neolítico que a domesticação de animais teve seu princípio e, nesse momento, observou-se a importância da paternidade na concepção. Através da domesticação de animais, passamos a entender melhor o papel masculino no processo da criação da vida e gradualmente, a dominação dos animais derivou no impulso de 'domesticação’ da terra (Getty, 1997, p.15). Evidente 
que, segundo essa autora, os animais passaram a ser os escravos e receber a carga que antes eram das pessoas. Os valores humanos começaram a mudar sob o exercício do poder.

No momento em que se constatou a importância da semente e sua ligação com a fecundação da terra, os homens passam a ser valorizados no processo da fecundação e corresponsáveis pelo princípio da vida (Santos, 2006). Com a criação de técnicas mais avançadas de cultivo do solo (o arado), é que o homem assume o papel de cuidar da terra. Papel este executado inicialmente apenas pelas mulheres, pois elas eram consideradas possuidoras da mesma magia da terra: a de propiciar o nascimento e a de nutrir os novos seres. O homem assume a liderança e, segundo Campbell (1990 a), a analogia entre a simulação do coito e do arado penetrando a terra, torna-se a figuração mítica dominante deste período. Seu papel aos poucos se reduziu ao de procriadora e mantenedora da família - dos herdeiros do patriarca. A magia e o encantamento do poder de gerar uma nova vida vindo das entidades femininas deram lugar a crença que todos os seres vivos fossem advindos de uma entidade masculina, um único Deus.

Paulatinamente, os homens começam a ministrar rituais sagrados que eram até então, prerrogativa das mulheres sacerdotisas. A deusa-Mãe foi aos poucos substituída por um deus-Pai, único, onipotente e onipresente, advindo originalmente da cultura judaica. ${ }^{18} \mathrm{O}$ papel do feminino que outrora fora supremo e divino, foi aos poucos suprimido. Contudo, a despeito disso, a Deusa não desapareceu totalmente do subconsciente das pessoas. $\mathrm{O}$ culto à deusa-Mãe era tão forte e presente em povos de cultura agrária que o cristianismo, muito sabiamente, valorizou a imagem da Virgem Maria, a Madona, como uma transposição da Grande Mãe. "O catolicismo vai suprimir a Deusa-mãe e criar o Deus-pai, mas devido à dificuldade de suprimir este culto, será criado o culto da Virgem Santíssima - a mãe de Deus e o Deus-filho." (Santos, 2006).

18 Posteriormente assimilada ao cristianismo. 


\section{A mulher como símbolo do pecado original e da redenção maternal}

"Mas o cristianismo, insistindo na castidade da Deusa Mãe, finalmente transformou o significado da imagem matriarcal, embora para todas aparências externas ela se manteve inalterada. A imagem da Deusa Mãe com seu filho representava sua sexualidade e poder de procriação, enquanto aquela da Virgem e seu filho representa seu celibato e a vontade de Deus. Ela era meramente a agente através da qual ele agiu"

Elinor W. Gadon (apud Gandon, 1989, p.192, tradução nossa)

No cristianismo ocidental, o poder que era atribuído à deusaMãe, foi transferido gradualmente para a Virgem Maria. Maria seria a personificação do amor incondicional e misericordioso, símbolo da maternidade e a mediadora da divindade. Sem dúvida, a Virgem Maria é a perpetuadora das inumeráveis Deusas Mães, anteriormente citadas (Senna, 2007). Mas a despeito de possuidora desta força maior, a Virgem Maria era a mãe de Deus, ou seja, a responsável por conceber e dar à luz a Jesus. Esta relação da mulher como provedora da vida, detentora de poderes divinos, porém com menor importância que um Deus masculino (onisciente, onipotente e onipresente), veio da Antiguidade Clássica, onde se alicerçaram os pilares da cultura ocidental. A raiz cultural greco-romana, sob a qual descendemos, está intrínseca e diretamente ligada ao nosso modo de pensar, de raciocinar, de se configurar socialmente e, inclusive, em nossos rituais religiosos. Herdamos dos gregos, entre tantas coisas, o modelo de democracia e política, os padrões de beleza e proporções arquitetônicas e artísticas, assim como a misoginia. ${ }^{19}$

19 Misoginia [Do grego misogynía]. S.f. 1. Desprezo, ou aversão às mulheres. 2. Med. Repulsa mórbida do homem ao contato sexual com as mulheres. [Antôn.: filoginia. Cf. ginecofibia.]. (Ferreira, 1975, p.929) 
Para a sociedade grega pré-cristã alguns homens eram considerados cidadãos livres - não todos, só os patrícios - com direito de pensar (logos), mas nem sempre de manifestar-se, porque censura também havia. Os patrícios possuíam bens, incluindo pessoas como suas esposas, filhos, outros parentes, e escravos; o que significa que havia um grande número de escravos, submetidos nas batalhas vitoriosas. A relação familiar e social instaurada era a de dominação e hierarquização do pai como o dono e senhor.

Segundo Pauline Shmit-Pantel, as relações entre mito e história, serviram para justificar as diferenças dadas em culturas e sociedades distintas entre os sexos. A autora toma como referência dois relatos de criação: a da Pandora na tradição grega e a de Eva na hebraico-cristã. Tanto em um, quanto no outro, a criação da mulher aparece como algo secundário, advindo somente após a criação do homem. "Associa a criação da mulher à origem daquilo que se pode denominar 'condição humana', ou seja, à introdução da morte e do mal no mundo." (Shmitt-Pantel, 2003, p.130)

$\mathrm{Na}$ mitologia grega, podemos observar uma grande semelhança nos primeiros seres criados Zeus, com o mito cristão descrito no Gênesis, assim como também o relato da criação da primeira mulher. Segundo conta este mito, Prometeu fez o homem através da mistura da água com a terra, semelhante à imagem dos deuses: de porte ereto, com capacidade de virar a cabeça para o céu e contemplar as estrelas, diferente dos animais que tem seu rosto voltado para o chão. A mulher foi feita pelo deus Júpiter, como punição a Prometeu e Epimeteu (irmãos), por haverem entregado o fogo do céu aos homens na terra e também ao homem, que o aceitou (Hesíodo, 1978, p.88 apud Furlani, 1992, p.5)

De acordo com o mito Pandora, primeira mulher criada, foi oferecida pelos Deuses à Epimeteu. A curiosidade de Pandora, considerada uma característica "natural" das mulheres, fez com que achasse uma caixa que Epimeteu havia escondido, por conter todos os males dos homens que não foram utilizados em sua criação. Obviamente, ao abri-la, a mulher deixou que todos os males e pragas se espalhassem por toda a humanidade. Ocorre que, ao se 
apressar em fechá-la, apenas um dos itens permaneceu no fundo da caixa, a esperança. "Assim, a lenda pagã ensinava que, embora a curiosidade da mulher tenha sido a responsável pelos males do corpo e do espírito que nos ameaçam, a esperança não nos deixa inteiramente; enquanto a tivermos, nenhum mal nos torna inteiramente desgraçados."'(Hesíodo, 1978, p.88 apud Furlani, 1992, p.5)

Segundo a mitologia grega, a mulher é o fruto da criação de Zeus para se vingar de Prometeu que roubou o fogo e o entregou aos homens. É por esta razão que ela é vista de forma negativa para este universo mítico. É curioso que ao observarmos o relato grego da criação masculina, vemos uma grande semelhança com o relato da criação hebraico-cristã - e podemos, inclusive, pensar na possibilidade de serem semelhantes, visto que as traduções podem alterar algumas palavras, mas sem que se perca o sentido semântico. Uma grande mudança pode ser notada apenas quando há referência à criação da mulher; pois ela foi "plasmada com a terra e a água pelo deus Hefaístos, ou seja, é uma invenção técnica, um produto artesanal, uma obra de arte, um artifício."(Shmitt-Pantel, 2003, p.131)

A psicoterapeuta Raissa Cavalcanti ${ }^{36}$ comenta a visão mais arquetípica do grego da criação do homem e da mulher como seres primordiais que eram um só corpo: "No início, conta-nos o mito, o homem e a mulher eram só um mesmo corpo e possuíam qualidades extraordinárias..." No Symposium, Platão narrou o mito sobre os seres primordiais que eram redondos, com quatro pernas e braços, duas faces (que olhavam para lados opostos) e, por possuir tamanha inteligência e poder, despertou a inveja e medo nos deuses. Então eles os cortaram em duas partes, uma feminina e outra masculina e até hoje as partes procuram se unir novamente. "Hermafrodito, o filho de Hermes e Afrodite" - continua Cavalcanti - "é o ser mítico que reúne em si mesmo as duas partes, o masculino e o feminino; ele é o símbolo da totalidade." Ainda, segundo a autora, "o mito nos indica um modelo arquetípico de funcionamento." O mito de criação nos faz compreender que o ser humano maduro tem consciência de reunir em si próprio o masculino e o feminino. Reitera 
a psicoterapeuta: "Somente quando essa reunião ocorrer internamente dentro do homem e da mulher, será possível o encontro mais verdadeiro entre os dois" (Cavalcanti, 1993, p.137)

Como Zeus, na hierarquia mitológica grega, era detentor do poder supremo, a deusa-Mãe foi dividida e diluída em uma profusão de divindades femininas. Hera e Demeter eram as deusas da fertilidade, da fecundidade do solo e das mulheres. Ártemis, a deusa da caça, estava ligada à natureza. Atena era a deusa das artes, do artesanato e da sabedoria. Afrodite era a deusa do amor, da sedução e da beleza, e foi a mais predominante entre as outras, em termos de representação. Foi através das várias representações das deusas, que se originou a tradição do nu feminino na arte do Ocidente. "Uma figuração que evidencia, em detrimento do caráter divino, o aspecto erótico e sensual." (Senna, 2007, p.63)

Esses mitos sobre as origens dos deuses e deusas, sobre a origem da vida ainda são de muitas formas perpetuados nos dias de hoje. Fica evidente que as raízes culturais do ocidente estão intrinsecamente ligadas aos preceitos bíblicos hebraico-cristãos que, por sua vez, foram gerados na cultura grega. O Gênesis narra a superioridade do homem sobre a mulher: Adão, o primeiro ser humano criado por Deus, foi feito de barro e do sopro divino em suas narinas. Depois de concluir que Adão não deveria viver sozinho, Deus criou Eva para ser sua companheira e para criá-la, tirou-lhe uma costela:

E disse o senhor Deus: Não é bom que o homem esteja só. Farlhe-ei uma ajudadora que esteja como diante d'elle. Havendo pois o Senhor deus formado da terra todo o animal do campo, e toda a ave dos céus, os trouxe a Adão, para este ver como lhes chamaria; e tudo o que Adão chamou a toda a alma vivente, isso foi seu nome. E Adão poz os nomes a todo gado, e as aves dos céus, e a toda a besta do campo; mas para o homem não se achava ajudadora que estivesse como diante d'elle. Então o Deus Eterno fez cair um somno pesado sobre Adão, e este adormeceu: e tomou das suas costellas, e cerrou a carne em seu logar; E da costella que o Senhor Deus tomou do homem, formou uma mulher: e trouxe-a a Adão. E disse Adão: 
Esta é agora osso dos meus ossos, e carne da minha carne: esta será chamada varôa, porquanto do varão foi tomada. (Bíblia, 1950, Gênesis, 2: 18/23)

Através das escrituras, o homem assume no criacionismo a primazia que era da mulher. A Bíblia nos conta que homem e mulher viviam de modo harmonioso no Éden, até que foram expulsos devido à imprudência de Eva que, induzida pela serpente, mordeu o fruto proibido pelo Senhor. Que fruto era esse? O fruto da sabedoria. A inocência era a ignorância. Assim, toda a humanidade foi condenada a viver sob o jugo do pecado e, por isso, dizem as regras católicas que todos que nascem necessitam ser batizados para se livrarem do pecado original. A serpente, animal que outrora estava ligado aos símbolos femininos pela sua capacidade de renovação da vida (a troca de pele), é descrita como "a mais astuta que todas as alimárias do campo que o Senhor Deus tinha feito" (idem, Gênesis, 3: 2/13)". A serpente teria desafiado Eva, perguntando: - Por que não comer os frutos de todas as árvores do jardim? Não se trata do Éden? Eis que a mulher responde que ambos poderiam comer os frutos de qualquer árvore, a não ser da que estaria no meio do jardim, porque Deus havia proibido. A serpente argumenta que Deus sabe que este fruto é capaz de abrir os olhos de ambos, trazendo o conhecimento do bem e do mal. "E viu a mulher que aquela árvore era boa para se comer, e agradável aos olhos, e árvore desejável para dar entendimento; tomou do seu fruto, e comeu, e deu também ao seu marido, e ele comeu" (idem, ibidem). Segundo a narrativa bíblica, ambos se envergonharam, por tomarem conhecimento de que estavam nus; então colheram folhas de figueira para cobrirem-se. Ao perceberem a presença de Deus no jardim se esconderam entre as árvores. Deus teria questionado Adão para saber qual o motivo deles terem se escondido e ele respondeu que ao ouvir sua voz, temeu e se escondeu, por estar nu. Ao que Deus teria respondido: "Quem te mostrou que estavas nu? Comeste da árvore proibida?" E Adão, feito covarde pelas escrituras, respondeu: "A mulher que me deste me ofereceu o fruto proibido” (idem, ibidem). A culpa ficou 
com a serpente - o mal. Esse trecho tem o título: Tentação de Eva e queda do homem.

Eva é filha de Lilith, ${ }^{20}$ o demônio fêmea dos hebreus, cujo pecado é a sedução, representada, sobretudo, pelos cabelos, que amarram, que prendem... Mas a eufemização foi necessária, porque a mãe de todos os cristãos não podia ser o demônio, então a serpente se tornou a grande vilã. O símbolo do ciclo do tempo perdeu a carga simbólica positiva que o mantinha no nível mítico, para ser o símbolo do mal, esmagada sob os pés da Nossa Senhora, em várias aparições. Conforme as escrituras, Deus teria dito: "Como castigo, as mulheres terão os filhos com dor e os homens deverão trabalhar, e comer do que plantam." Neste ponto, devemos nos lembrar de que a primeira tradução da Bíblia, do aramaico, foi a grega. E, para os gregos, as mulheres eram desconsideradas. Matronas serviam essencialmente para a maternidade e o cuidado dos filhos pequenos, até os sete anos. O trabalho era atribuição apenas dos escravos, ou seja, poderia ser encarado como uma grande e penosa punição a todos os homens. As escrituras têm um sentido punitivo: $\mathrm{O}$ corpo é pecaminoso, o trabalho é castigo, o plantio e o fruto colhido têm gosto ruim e o parto é martírio. Qualquer semelhança com os preconceitos que vivemos hoje no mundo ocidental não é mera coincidência.

E à mulher disse: Multiplicarei grandemente a tua dor, e a tua conceição; com dôr parirás filhos; e o teu desejo será para o teu marido, e elle te dominará. E a Adão disse: Porquanto deste ouvidos á voz de tua mulher, e comeste da arvore de que te ordenei, dizendo: Não comerás d'ella: maldita é a terra por causa de ti; com dôr comeras d'ella todos os dias da tua vida. Espinhos, e cardos também,

20 Mito encontrado no Talmude, livro hebraico banido da Bíblia e da memória da humanidade. Lilith foi a primeira mulher de Adão criada por Deus da terra, do mesmo modo que ele. Ela reivindicava a igualdade e não aceitava o papel de inferioridade e passividade, que depois foi assumido por Eva. Lilith tinha como características a autonomia, sensualidade e insubmissão ao jugo masculino, o que a fez fugir do paraíso (Lamas, 1997, p.33). 
te produzirá; e comerás a herva do campo. No suor do teu rosto co-o teu pão, até que te tornes á terra; porque d'ella foste tomado: porquanto és pó, e em pó te tornarás. E chamou Adão o nome de sua mulher Eva; porquanto ella era a mãe de todos os viventes. E fez o Senhor Deus a Adão e a mulher túnicas de pelles, e os vestiu. (Bíblia, Gênesis, 3:16/21)

Pode-se, ainda, pensar por que, até o momento em que ambos são expulsos do Paraíso, apenas o homem possuía um nome. É o homem, Adão, quem dá o nome para a sua mulher - Eva. Segundo a psicanalista Marilene Lima, ao dar-lhe um nome, o poder de dominação dos homens sobre as mulheres é reafirmado mais fortemente, uma vez que o ato de "nomear, uma das primeiras habilidades do ser humano, é manter sobre aquilo que se nomeia um controle psíquico." ${ }^{21} \mathrm{E}$ assim, modelando esse conceito, a supremacia do homem com relação à mulher se solidifica: "Durante a Idade Media, Santo Agostinho irá reafirmar a primazia do homem, que nasce, de acordo com a Bíblia, primeiro que a mulher, que por seu instinto pecador irá marcar pelo resto da vida a existência da humanidade pecadora pelo prazer sexual." (Santos, 2006) No ensaio de Emanuel Araújo, "A arte da sedução: sexualidade feminina na Colônia", esse pensamento misógino é expresso duramente por dois dominicanos alemães, Heinrich Krämer e Jacob Sprenger no célebre tratado de demonologia escrito, Malleus maleficarum, publicado em 1486. Segundo eles, por ter sido criada a partir de uma costela do homem, houve uma falha na formação da mulher já que essa curvatura é contrária a retidão do homem, e "em virtude dessa falha, a mulher é animal imperfeito, sempre decepciona a mente." (apud Priore, 2008, p.46)

Para as mulheres, vista unicamente por esse ângulo, restava apenas obedecerem aos seus pais, irmãos e, depois de casadas, aos seus maridos. Era preciso que sempre mantivessem um comportamento

21 Artigo disponível em: http://www.pedagobrasil.com.br/psicologia/educacaopsicanalise.htm. Acesso em 22/07/08. 
social exemplar, sendo castas, educadas, respeitosas e pacientes, cumprindo claro e definido papel social. "Repetia-se como algo ideal, nos tempos coloniais, que havia apenas três ocasiões em que a mulher poderia sair do lar durante toda a sua vida: para se batizar, para se casar e para ser enterrada." Estava evidente que o único modo de redenção para as mulheres ocorria exclusivamente através da maternidade. A igreja era a grande responsável pelo direcionamento opressivo da sexualidade feminina. "O fundamento escolhido para justificar a repressão da mulher era simples: o homem era superior e, portanto, cabia a ele exercer a autoridade." Na Epístola aos Efésios, ${ }^{22}$ São Paulo deixa bem claro esse posicionamento perante a condição feminina: "As mulheres estejam sujeitas aos seus maridos como ao Senhor, porque o homem é a cabeça da mulher, como Cristo é a cabeça da Igreja... Como a Igreja está sujeita a Cristo, estejam as mulheres em tudo sujeitas aos seus maridos." A figura do homem dentro de casa, simbolizava a figura de Deus. E a mulher foi condenada à submissão, com a desculpa do pecado de Eva. "Já que a mulher partilhava da essência de Eva, tinha de ser permanentemente controlada."(Araújo apud Priore, 2008, p.46)

A relação entre homens e mulheres, entre seres humanos e natureza será sempre uma questão instável e o papel da mulher na sociedade, de certa forma, ainda permanece mutante, consolidando-se conforme as necessidades de uma determinada época. Sabemos apenas que nossos ancestrais teriam tido uma relação mais mágica e mítica com os ciclos naturais, com a idéia da origem da vida e outros mistérios que envolviam a existência. A Grande-mãe da sociedade pagã passou a ser a singela mãe que devia se envergonhar e esconder a sua gestação, por ser fruto de um pecado carnal. O que antes era venerado como um dom, um grande conhecimento ou uma sabedoria da natureza, passou a ser visto como uma obrigação divina, um fardo, na sociedade cristã. De sacerdotisas e médicas, as mulheres foram julgadas pelos cristãos poderosos, como "bruxas", que deveriam ser mortas exemplarmente, com requintes de perversidade.

22 Epístola aos Efésios 5: 22-24. 
A Deusa Mãe deu à luz um Deus Pai. De uma relação harmoniosa entre mulheres, homens e natureza, surgiu a supremacia do pensar racional, advinda da configuração social do patriarca. É o patriarcado que, abaixo de Deus, hierárquica e autoritariamente falando, coloca o homem como a imagem e semelhança dele, a mulher como sua companheira submissa e a natureza como fonte de energia e matéria-prima disponível à exploração dos humanos. 


\section{2 \\ O FEMININO NA ARTE \\ E A ARTE DO FEMININO: \\ MOVIMENTOS LIBERTÁRIOS DO SÉCULO}

"As mulheres foram, durante muito tempo, deixadas na sombra da história".

Georges Duby e Michelle Perrot, História das mulheres no ocidente

A grande questão elaborada no início do século XX por Freud, pai da psicanálise, sobre o que realmente queriam as mulheres, ainda ecoa. Porém, agora, com respostas mais plausíveis. As mulheres querem ser donas de sua própria vida, no sentido da necessidade de ter o poder de escolha para exercerem sua vocação, seja como profissional, mãe, pesquisadora, dona-de-casa ou mesmo no acúmulo de todas as funções simultaneamente. Elas querem aquilo que lhes foi negado por séculos: ser uma pessoa no amplo sentido, com todos os direitos e deveres, com todos os prazeres e dores, com todas as certezas e angústias. Marina Maluf e Maria Lucia Mott comentam essa mesma angústia feminina em um artigo publicado na Revista Feminina: ${ }^{1}$

1 A Revista Feminina foi analisada e citada diversas vezes no artigo Recônditos do mundo feminino, de Marina Maluf e Maria Lucia Mott. "Trata-se de uma importante publicação com sede em São Paulo e com uma excelente distri- 
E quais seriam nesses tempos os sinceros desejos da mulher?, indagava a escritora Chrysanthème (pseudônimo de Cecília Bandeira de Melo Rebelo de Vasconcelos) à sua personagem, que lhe respondia, aborrecida com o tom protetor e de disfarçado desdém dos homens superiores: "Nós queremos a liberdade [...] ou pelo menos a sua igualdade com o homem, o nosso déspota, o nosso tirano." "Sejamos mulheres", proclamava de Minas Gerais uma colaboradora da Revista Feminina, em 1920. Reivindicando igualdade de formação para ambos os sexos, chamava a atenção das leitoras para as mulheres "vitimas do preconceito", que viviam fechadas no lar, arrastando "uma existência monótona, insípida, despida de ideais," monetariamente algemadas aos maridos. (Maluf e Mott, 1998, p.370 e 371)

Para mencionar a história das mulheres no mundo ocidental, mesmo que seja um breve recorte, não podemos deixar de considerar que boa parte dos documentos oficiais, há menos de dois séculos, foi escrita por homens. Eram os homens, na sua maioria, que tinham acesso a ler e escrever e, consequentemente, eram eles que detinham o poder do conhecimento e da razão. Segundo Berenice Lamas (1997), a escolarização feminina remete aos papéis tradicionais, ou seja, para a maioria das mulheres, seu destino seria educar-se para profissões femininas como magistério, ou mesmo

buição. Circulou entre 1914 e 1936, contava com a colaboração de jornalistas e escritores de renome de todo o Brasil, com também de leitoras e leitores, e publicava matérias traduzidas da imprensa estrangeira. Entre os colaboradores mais importantes encontram-se o escritor Cláudio de Souza, que assinava os editoriais da revista com pseudônimo feminino de Ana Rita Malheiros, Coelho Neto, Antonio Austregésilo, Menotti Del Picchia e as escritoras Julia Lopes de Almeida e Chrysanthème. Destinava-se sobretudo ao público feminino, com seções sobre comportamento feminino, relacionamento conjugal, etiqueta, culinária, moda, trabalhos manuais. Publicava contos, charges, artigos de assuntos gerais e muita publicidade. Os números da revista podiam ser comprados avulsamente ou por assinaturas. Vendida em todo o Brasil, alcançou uma tiragem de ate 25 mil exemplares por mês, o que a coloca entre as revistas de maior circulação no período.” (Maluf e Mott, 1998, p.639-640) 
dedicar-se ao lar e casamento. Constatamos que, ao longo da história, o processo de educação feminina foi pensado a partir do ponto de vista masculino. Esse olhar buscava conformar as mulheres à obediência e à submissão, como mostra o fato de, até o século XVII, as mulheres serem, na sua grande maioria, analfabetas.

Mesmo que muitas mulheres não estivessem marginalizadas dos meios intelectuais e artísticos, foram poucas as constatações de sua presença registradas na história. Apesar de terem sido suprimidas em boa parte da história da arte como artistas, as mulheres foram tema de inúmeras representações artísticas desde os mais remotos tempos. Temos infindáveis obras onde o corpo da mulher aparece tanto de forma despida, como parcial ou totalmente encoberta. Luciana Loponte (2002) cita dois grandes artistas da pintura moderna, Manet (impressionista) e Picasso (cubista), e suas respectivas obras que marcaram época na história da arte: Almoço na relva e a famosa pintura Les demoiselles d'Avignon. Esses artistas, assim como tantos outros, são exemplos de como os corpos femininos são um tema recorrente, onde se consolidou um olhar masculino sobre o feminino. “A chamada 'história universal da arte' é uma história particular, que sistematicamente vem privilegiando um determinado modo de ver como o único possível." (Loponte, 2002). Podemos observar que tanto Almoço na relva, quanto Les demoiselles d'Avignon, as mulheres estão representadas de modo passivo e submisso, sem terem um papel atuante na obra, apenas cumprem o papel de posar como modelos. Aos homens, foi prestado o papel atuante de artistas criadores, aqueles que executam e têm o domínio da ação. Eles eram os únicos protagonistas que atuavam como os autores, os artistas, os espectadores, os marchants ou os compradores e colecionadores de objetos artísticos (Berger, John apud Loponte, 2002).

Para a crítica de arte professora Mariza Bertoli, ${ }^{2}$ entrevistada sobre o tema:

2 Mariza Bertoli é conselheira na Sociedade Científica de Estudos da Arte, membro da Associação Brasileira de Críticos de Arte e da Associação Internacional de Críticos de Arte. A entrevista foi concedida à autora em 15/05/09. 
Este argumento é contestável já que tanto em Manet como em Picasso e, sobretudo nas obras citadas, o que se vê não é submissão ou passividade, mas uma visão erótica, muito mais de reverência à mulher e de celebração à beleza. Em Almoço na relva, a figura da mulher reina soberana, o foco da figuração é ela, que olha o espectador com desdém, como quem diz: - Eu sou o almoço. Da mesma forma, Les Demoiselles d'Avignon, marco do cubismo, elogio à estética africana, rompe com os estereótipos de beleza feminina herdados do classicismo. O que dizer de Vermeer de Delf, que retratou costureiras, cozinheiras, mulheres lindas banhadas em luz, dignificando os ofícios humildes, como se fossem ícones sagrados? E a Moça dos brincos de pérola, que é uma confissão de paixão correspondida - comovente. Me sentiria honrada em ser qualquer destes modelos.

Mas, como todos sabemos, o século XX foi certamente o momento no qual as mulheres tiveram a oportunidade de, gradualmente, mudar essa situação e "a participação das mulheres na vida cultural conhece um desenvolvimento sem precedentes nas sociedades ocidentais." (Duby e Perrot, 1990, p.351) O mercado de trabalho, a vida intelectual e artística foram aos poucos sendo abertos para que elas pudessem emergir e expandir-se para outros novos horizontes. Os gritos de socorro e as atitudes das mulheres que antecederam este século foram determinantes para essa incursão, especialmente no mundo das artes visuais. Muitas foram as mulheres que nos séculos XVIII e XIX lutaram, mesmo que de forma parcial, para que, somente a partir da segunda metade do século $\mathrm{XX}$, se começasse a colher os frutos plantados por essas pioneiras.

Apesar das resistências, três fenômenos se conjugam para favorecer esta participação. Em primeiro lugar, as lutas feministas, travadas desde o final do século XIX pela igualdade de estudos e de diplomas, conseguem êxitos evidentes. Depois, a evolução das técnicas, o crescimento do público amador e o aumento dos tempos livres conduzem, a partir dos anos cinqüenta, a uma difusão maciça 
das obras de arte. Por fim, as novas estruturas da produção cultural, que dão origem, em particular, a um salário importante permitem às mulheres conquistar uma maior autonomia e visibilidade social. Elas são, assim, cada vez mais numerosas nas profissões intelectuais e artísticas, com uma aceleração sensível na segunda metade do século. (Duby e Perrot, 1990, p.351)

As três primeiras décadas do século XX foram marcadas por mudanças extremamente significantes no que diz respeito ao comportamento feminino perante a sociedade ocidental. O desenvolvimento da antropologia e a ênfase dada à família, a afirmação da história das 'mentalidades', mais atenta ao cotidiano, ao privado e ao individualismo, contribuíram para que fosse possível, para as mulheres, saírem da sombra, deixando, num processo lento e moroso, a forte opressão vivida por milhares de anos. "Outro aspecto histórico importante é o ganho das sufragistas no inicio do século: mulheres inglesas e francesas conquistam o direito de participar da vida política, tendo acesso ao voto." (Lamas, 1997, p.31)

No Brasil, onde ainda mantivemos por muito tempo resquícios de uma colônia portuguesa, apenas algumas poucas jovens abastadas ousavam desfilar aos modos e modas europeus nas conservadoras capitais dos estados do Rio de Janeiro e de São Paulo. "Afinal, era muito recente a presença de moças das camadas médias e altas, as chamadas de 'boa família', que se aventuravam sozinhas pelas ruas da cidade para abastecer a casa ou para tudo o que se fizesse necessário.” (Maluf e Mott, 1998, p.368)

Se os anos vinte apresentam os sinais de uma emancipação feminina, cabelos curtos, modos arrapazados e direito de voto para as Inglesas, a vida quotidiana das mulheres evolui pouco; o ideal da mulher no lar e a repartição dos papéis que ele implica parecem, mais do que nunca incontestados. A sua inserção em regimes democráticos permitiu às mulheres, na França como na Inglaterra, escapar ao recrutamento totalitário, mas não anula a especificidade das duas sociedades que, apesar de igualmente desenvolvidas, não dei- 
xam de apresentar características originais que modelam largamente o lugar das mulheres na sociedade. (Duby e Perrot, 1990, p.115)

Vejam que até mesmo em países onde eclodiram as revoluções sexistas, França e Inglaterra, ainda no início do século XX, podemos observar que era esperado das mulheres uma postura servil. Por mais modernos que fossem os cortes de cabelo, as roupas curtas, os modos mais liberais, a tradição feminina como "rainha do lar" ainda continuava a se perpetuar.

Era corrente pensar que havia uma "natureza feminina" que conduzia as mulheres à esfera do lar, como se elas fossem dotadas biologicamente de uma capacidade exclusiva de casarem, terem filhos e cuidarem de tudo que envolvesse a vida privada. Ao homem, nesse modo de relacionamento, suas funções sociais não poderiam caber nesse espaço privado, uma vez que lhe competiam as tarefas fora do lar, ou seja, a rua e os negócios. "A imagem de mãe-esposa e dona de casa como a principal e mais importante função da mulher correspondia aquilo que era pregado pela Igreja, ensinado por médicos e juristas, legitimado pelo Estado e divulgado pela imprensa." (Maluf e Mott, 1998, p.374)

Em 1916, ano em que foi aprovado no Brasil o Código Civil da República, ${ }^{3}$ criou-se o manual de economia doméstica, intitulado $\mathrm{O}$ lar feliz. Este manual era destinado à um público amplo, em especial às jovens mães e esposas que fossem realmente dedicadas ao seu lar. Nele, o autor divulga o papel a ser desempenhado por homens e mulheres, acentuando o "respeito mútuo, que pode ser traduzido como a expressa obediência de cada sexo aos limites do domínio do ou-

3 No Código Civil de 1916 existem vários preceitos que sacramentam a inferioridade da mulher casada com relação ao seu marido. Nessa nova ordem jurídica, a esposa foi "declarada relativamente inabilitada para o exercício de determinados atos civis, limitações só comparáveis às que eram impostas aos pródigos, aos menores de idade e aos índios." Desta forma, a mulher era dependente e estava subordinada legalmente ao homem, o senhor da ação. (Código Civil da Republica dos Estados Unidos do Brasil, apud Maluf e Mott, 1998, p.374-375). 
tro." Dentre as inúmeras regras, normas, deveres e obrigações que o Código Civil de 1916 impôs, também estava interpretado o modo como cada cônjuge deveria se apresentar socialmente. A cada representante matrimonial era conferido um atributo que fosse essencial. A valorização do papel do homem na sociedade foi relacionada ao fato de as atividades exercidas por eles serem "dotadas de poder e valor", pois sendo eles os provedores financeiros do lar, eram eles os responsáveis pela "manutenção, assistência e proteção dos seus. [...] Não se pode esquecer que a contrapartida do marido provedor era a mulher responsável pela honra familiar." Ou seja, para um lar feliz e completo, ambos deveriam cumprir seus papéis rigorosamente, pois seria vergonhoso perante a sociedade se houvesse alguma falha entre uma das partes. "A arquitetura do lar feliz aprisionou homens e mulheres dentro de uma moldura estritamente normativa." Ambos tiveram que se "defrontar não só com uma noção mais delimitada dos papéis sociais atribuídos a cada sexo mas, sobretudo, com uma rigidez provavelmente desconhecida até então em suas experiências cotidianas." (Maluf e Mott, 1998, p.374 a 382)

Apesar de bem definidos os papéis dos homens e das mulheres, muitas indagações ainda pairavam na sociedade do início do século XX. Especialistas das mais variadas áreas se empenhavam em estabelecer um padrão definido pelos caracteres sexuais do homem e da mulher.

A posição de cada sexo está ligada à sua configuração morfológica. A rapariga é diferente do rapaz, sendo menos que este, privada como está desse pênis que lhe falta, de quem tem "inveja" e de que não encontra senão um pálido sucedâneo no clitóris. O sexo feminino é definido negativamente em relação ao sexo masculino. Tornar-se mulher é aceitar não ser homem, através de um laborioso itinerário cujas peripécias não descrevemos aqui. (Duby e Perrot, 1990, p.322)

Simone de Beauvoir, no livro O segundo Sexo (1970), foi uma incontestável referência para a história do pensamento feminista. 
Quando a autora afirmou que não se nascia mulher, mas tornava-se mulher, ela estava reforçando o papel que as mulheres deveriam assumir na sociedade patriarcal, onde lhes são impostos um complexo sistema de constrangimentos tanto no âmbito educacional, social, legislativo etc. "Assim, a mulher é sempre 'o outro' do sujeito homem." Simone descreve, minuciosamente, as três grandes fases da mulher, desde as primeiras regras, passando pela maternidade, culminando na menopausa. Nessa descrição, a autora demonstra como funcionava na sociedade a compreensão habitual do caráter inferior do corpo feminino. "[...] Ao mesmo tempo em que sublinha a pesada contingência corporal das mulheres, Simone de Beauvoir afirma a sua capacidade de se libertar dessa contingência para se tornarem plenamente humanas." (Duby e Perrot, 1990, p.343)

[...] a estrutura das relações entre homens e mulheres é uma estrutura de poder, que assegura a dominação daqueles sobre estas. Partindo deste ponto comum, o pensamento feminista diversificase infinitamente quando se trata de saber como e com que objetivo essa estrutura deve ser abolida, e o que é feito da diferença sexual quando ela escapa à sua determinação. (Duby e Perrot, 1990, p.342 e 343)

A liberdade feminina foi operada juntamente com a junção de diversos registros determinantes: o da família, o do trabalho e o da libido. A transformação das relações familiares e de trabalho, para a mulher, afetou diretamente suas questões sexuais e, consequentemente, a sua libido. Alguns valores que antes eram apenas uma prerrogativa dos homens, como o amor livre e a troca de parceiros, eram valores obstinadamente reivindicados por algumas feministas, como o caso da russa Alexandra Kollontai em seu livro Marxismo e a revolução sexual (1973). "Influenciadas pelo marxismo, pela história social, pela filosofia lingüística e pela psicanálise, acabaram por questionar os postulados e categorias mais acarinhados da história da arte." Essas feministas ainda sustentavam que alguns conceitos como "autoria, originalidade e obra-prima não são 
os fundamentos da criatividade mas, antes, as conseqüências dos processos culturais pelos quais feminilidade e masculinidade são preservados." (Duby e Perrot, 1990, p.115 e 424)

Esse período de significativas mudanças, ocorridas entre as décadas de 1960 e 1970 no ocidente, foi caracterizado principalmente pela emancipação sexual das mulheres e pela afirmação de igualdade entre os sexos. As novas invenções tecnológicas, como o advento da pílula anticoncepcional (no início dos anos de 1950) e a descoberta de antibióticos que tratavam as doenças sexualmente transmissíveis (a partir de 1941) e com a divulgação do preservativo de látex na década de 1930, as mulheres tomaram o controle da função reprodutora do seu corpo e se livraram da submissão masculina neste aspecto. Essa revolução sexual marcou, de certa maneira, o fim do patriarcado, da censura, assim como o progresso na igualdade das mulheres nas legislações nacionais. Toda essa revolução sociocultural, também, acarretou um deslocamento da atenção de muitas artistas, críticas e historiadoras, para o problema da construção social de uma identidade feminina. Na sua maior parte, essas mulheres acreditavam que tanto a teoria como a prática deveriam colaborar para mudar o modo como compreendemos nosso passado e, ao mesmo tempo, como reelaboramos nosso presente. Assim, essas pensadoras pretendiam evitar ao menos duas posições: "[...] uma posição existencialista que procura restituir ou definir uma sensibilidade ou uma estética comum a todas as mulheres independentemente da sua classe social ou da sua raça;" e, em contraponto, "uma estratégia desconstrutiva tão relativista que impediria qualquer ação política passada ou presente." (Duby e Perrot, 1990, p.424) Ou seja, elas definitivamente não pretendiam estagnar os valores, conceitos ou circunstâncias que as fixassem em um posicionamento maniqueísta.

Observa-se, portanto, um processo longo para desatar os laços que prendiam as mulheres ao seu passado extremamente "doméstico" (ligado aos afazeres do lar e de uma vida dedicada à família), com seu presente repleto de novos desafios. Aos poucos, e ainda hoje, vemos as mulheres conquistando diversos espaços, sem que 
seja preciso renunciar à vida familiar. As mulheres hoje conseguem, de forma magistral, dividir seu tempo para as múltiplas atividades que exercem simultaneamente. Esta é uma característica presente no universo feminino, um universo múltiplo, flexível e acolhedor.

\section{A feminilidade se regenera (se gera) na arte através das mulheres}

"É difícil, entre nós, a elaboração de uma linguagem do feminino, na visualidade contemporânea. A mulher busca os seus idiomas próprios, nos espaços recém-abertos para ela."

Lélia Coelho Frota, A fala feminina

O conceito de História que hoje conhecemos foi construído através de uma lógica e um pensamento que estavam recalcados sob o crivo do momento em que ela foi escrita: "A história é objeto de uma construção cujo lugar não é o tempo homogêneo e vazio, mas um tempo saturado de 'agoras'” (Benjamin, 1986, p.229). Ou seja, a história será sempre produto de pontos de vista relativos a uma determinada época e, portanto, terá uma carga considerável de parcialidade. Logo, resgatar uma história da arte feminina, desenvolvida ao longo dos tempos, é, sem a menor dúvida, um trabalho que requer uma pesquisa vasta e será, necessariamente, parcial. Conforme já mencionamos na introdução, não temos aqui esta pretensão. Apenas destacaremos algumas poucas mulheres que se consagraram através de sua arte.

Durante toda a Idade Média, a grande maioria dos artistas não assinava suas obras, porque o sistema da arte estava ligado ao poder religioso. Nesse longo período, os artistas eram considerados "operários de Deus", ferramentas que manifestavam apenas a vontade do grande criador. A figuração das liturgias, portanto, era realizada pelos artistas que viviam dentro dos mosteiros e conventos. Ao pensarmos uma arte feita pelas mulheres, não podemos deixar de 
considerar que ela resultou, na sua grande maioria, do trabalho das monjas que tiveram acesso à formação artística e desenvolveram o hábito de ler e escrever. Há registros comprovando a contribuição dessas mulheres que viviam em clausura nas iluminuras e ilustrações das cópias dos livros medievais. Elas eram poetisas e também especialistas em pinturas, sobretudo em miniatura, além de exímias bordadeiras que ornamentavam as vestes eclesiásticas (Chadwick apud Senna, 2007).

Apesar de serem muitas, poucas foram aquelas que tiveram seus nomes registrados para a posteridade; a abadessa alemã Hildegarda von Bingen, no século XII, foi uma delas. Ela chegou produzir um número considerável de obras com os mais variados temas, incluindo textos visionários, sermões, hinos, poesias, biografia de santos, obras de história natural, farmacologia, cosmologia e teologia. ${ }^{4}$ No século XIV, a francesa conhecida como "a jovem Bourgout" realizou inúmeras ilustrações juntamente com o seu pai, Jean le Noir. Na Itália do século XV, figurou uma grande artista monja, Caterina dei Vigri, canonizada Santa Catarina em 1712. No renascimento, a iconografia mariana foi representada por muitas artistas: Lavinia Fontana, Bárbara Longhi, Properzia de Rossi, Diana Mantuana e Elisabetta Sirani (Senna, 2007, p.66 a 71)

Nos séculos seguintes, mais precisamente a partir do século XVIII, encontramos com maior abundância obras de mulheres e, especialmente, das que desenvolveram a chamada "pintura de gênero." ${ }^{5}$ Segundo Janson (1996), Marie Louise Elisabeth Vigée Le Brun foi uma das melhores artistas de pintura em estilo rococó

4 Cf. Silva. Disponível em: www.ifcs.ufrj.br/ frazao/Bingen.htm. Acesso em: 13/06/09 às 22h30.

5 Pintura de gênero ou petit genre "faz referência às representações da vida cotidiana, do mundo do trabalho e dos espaços domésticos, que tomaram a pintura holandesa do século XVII. Em pleno florescimento do barroco na Europa católica, desenvolve-se nos Países Baixos, sobretudo na sua porção holandesa protestante [...]". Disponível em: http://www.itaucultural.org.br/aplicExternas/enciclopedia_IC/index.cfm?fuseaction=termos_texto\&cd_verbete $=912$. Acesso em 14/06/09 às 8h. 
francês. Casada com um pintor e negociante de arte, Jean-Baptiste Le Brun, a artista obteve muita fama, chegando a tornar-se a retratista de Maria Antonieta e pôde, através de sua arte, conhecer vários países da Europa. O mesmo autor ainda cita outra famosa artista do final do século XVIII, Angélica Kauffmann. Suíça de nascença, passou quinze anos entre os neoclássicos ingleses e foi um dos membros fundadores da Academia RealEssas artistas pertenciam à aristocracia e, por esta razão, tinham acesso à instrução, cultura geral, como deveriam ser todas as "moças prendadas". A arte que a maioria aprendia ou exercia estava mais ligada ao universo das inúmeras atividades manuais que uma moça de alta estirpe deveria saber, como tocar piano, bordar, desenhar, pintar, coser etc. Camille Claudel, já no final do século XIX, foi outra artista que conseguiu renome como escultora. Tornou-se assistente de Auguste Rodin e suas obras eram muitas vezes comparadas às do mestre e, com certa frequência, foi desacreditada da própria autoria. Durante mais de dez anos, a artista dedicou seu serviço e amor ao mestre. Quando, finalmente, Camille compreendeu que nunca se transformaria na Sra. Rodin, distanciou-se dele física e esteticamente. A obra A idade madura foi marcada como o momento da sua ruptura: uma mulher ajoelhada, tenta em vão, segurar a mão de um homem que parte sem olhar para trás e que é levado por uma figura alegórica. ${ }^{6}$

No mesmo período em que efervescia o movimento modernista, entre o final do século XIX e o início o XX, as mulheres consolidaram sua integração no meio artístico e cultural. De acordo com Grosenick (2005), gradualmente, entre os anos de 1910 e 1920, algumas artistas começaram a ter notoriedade e reconhecimento. Entre elas podemos citar: Sonia Delaunay e Natalia Goncharova; ambas iniciaram o aprendizado em academias russas, depois se aperfeiçoaram em Paris no início do século. No período da Primeira Guerra Mundial, com os dadaístas, agregou-se Hannah Hoch;

6 Cf. Gaudichon e Rivière. Disponível em: http://www.camilleclaudel.asso.fr/ pageweb/agemur.html. Acesso em 14/06/09 às 17h 
na década seguinte, a renomada pintora especializada em flores, Georgia O’Keefe; nas décadas de 1930 e 1940, a surrealista Meret Oppenhein, assim como outras mulheres que aderiram ao movimento, deram vazão à imaginação poética, mais do que à técnica. Nesse mesmo período, a escultura também passou a ser domínio do feminino. A brasileira Maria Martins foi uma grande escultora surrealista que teve uma projeção internacional, especialmente na França e nos Estados Unidos. A escultora conheceu e conviveu com grandes artistas do movimento surrealista, como Marcel Duchamp, André Breton, Alexander Calder, Salvador Dali, Max Ernst, entre outros (Daher, 2001, p.13).

O modernismo no Brasil teve duas grandes representantes femininas: Anita Malfatti e Tarsila do Amaral. Embora apenas Anita tivesse participado da Semana de Arte Moderna de 1922, ambas tiveram extrema importância para a história da pintura no Brasil. Anita apresentou, no início de sua carreira grande influência expressionista: ainda jovem foi estudar em Berlin, onde entrou em contato com as vanguardas e os artistas europeus. Em 1915/16, quando ainda estava estudando nos Estados Unidos, Anita pintou A boba. Este quadro foi uma das obras que a artista expôs em 1917 uma polêmica exposição que foi considerada o marco inicial do movimento modernista no Brasil. ${ }^{7}$ Tarsila criou uma audaciosa linguagem de signos e formas, trazidas das memórias de sua infância e, também, dos registros gráficos da sua expedição "descoberta do Brasil”, no carnaval do Rio de Janeiro em 1924 e nas cidades históricas de Minas Gerais. Sua obra de maior impacto foi Abapuru ${ }^{8}$ que estimulou Oswald de Andrade a redigir o Manifesto Antropofágico ${ }^{9}$ em 1928. Na década de 1940, a brasileira Djanira da Motta

7 Cf. Francoio. Disponível em: http://www.macvirtual.usp.br. Acesso em: 14/06/09 às $19 \mathrm{~h}$

8 Do tupi-guarani, aba: homem / poru: que come (cf. Amaral, 1998. p.4).

9 Trecho do Manifesto antropofágico: "Só a Antropofagia nos une. Socialmente. Economicamente. Filosoficamente./ [...] Tupi, or not tupi that is the question./[...] Só me interessa o que não é meu. Lei do homem. Lei do antropófago./ Estamos fatigados de todos os maridos católicos suspeitosos postos em 
e Silva despontou como artista, desenhando diversos temas brasileiros. No início de sua carreira, foi considerada por muitos como uma artista primitivista ou, até mesmo, ingênua. A despeito dessas afirmações, Djanira certa vez afirmou que ingênua era ela, e não a sua arte (cf. Rampazzo, 1993). Um dos seus temas recorrentes era a religiosidade - como ilustra Senhora Sant'Ana de pé.

Sua própria fé católica e costumes populares (sincretismo religioso) marcariam muitas de suas obras. Podemos notar que existem atributos, em sua pintura, de um modelo modernista, seja na sua simplificação formal, nas superfícies rasas e chapadas (sem muita profundidade), nas cores puras, com um ritmo acentuado das linhas e contornos. Djanira atingiu-o de modo progressivo e, aos poucos, foi criando um estilo próprio, "uma obra que poderíamos chamar de djaniriana” (cf. Rampazzo, 1993).

O feminismo pareceu ser o prenúncio de uma nova era, ao menos para uma nova postura social: as mulheres tomaram finalmente as rédeas da situação, tornando-se curadoras, produtoras de arte, organizadoras, diretoras culturais, professoras em universidades etc. Juntamente com essa onda revolucionária dos movimentos libertários, as manifestações sociais das chamadas minorias fizeram os reacionários sentirem a sua voz e engolirem a sua imagem. Surgiram outras formas de expressão artística como arte conceitual ou performance, onde os posicionamentos e os corpos se investem de ideologia, rejeitando o aspecto mercantil de objetos. Outros estilos e abordagens também surgem como a pop art, op art, land art, minimal art, arte povera, fotorrealismo, happenings, body art, performance etc. Marielle Toulze (2003) explica que a Escola de Frankfurt e os trabalhos dos acionistas de Viena, a arte corporal (também

drama. Freud acabou com o enigma mulher e com outros sustos da psicologia impressa./ [...] Filhos do sol, mãe dos viventes. Encontrados e amados ferozmente, com toda a hipocrisia da saudade, pelos imigrados, pelos traficados e pelos touristes. No país da cobra grande. Foi porque nunca tivemos gramáticas, nem coleções de velhos vegetais. E nunca soubemos o que era urbano, suburbano, fronteiriço e continental. Preguiçosos no mapa-múndi do Brasil" (idem, ibidem). 
chamada body art) reifica o corpo e o ultrapassa. Até o absurdo cometido na performance citada em que Gina Pane, cortou-se com uma lâmina para "abrir-se aos outros". O corpo, como tema de debate social da época converge com as lutas sociais da inclusão dos negros, dos homossexuais e vem junto com a luta de liberação das mulheres. A performance ou o acontecer em arte ganhou espaço o corpo registrado, teatralizado, adulterado tornou-se palco de muitas as revoluções individuais e sociais.

Marina Abramović (1946) é uma artista que usa seu corpo como a base de seu suporte artístico. Rhytm 0, 1974 foi uma polêmica performance que consistia em, durante 6 horas, se deixar interferir qualquer fruidor. Nas últimas décadas, Abramović tem atrelado de forma mais forte sua biografia aos seus trabalhos. Balkan Erotic Epic, 2005 (Épico Erótico dos Bálcãs) é uma videoinstalação, com uma série de enormes projeções na sala, onde são mostrados os ritos pagãos da sua cultura. Esses rituais são extremamente ligados ao sexo e ao erotismo: falos, seios e vaginas estavam ligados a uma idéia de fertilidade do solo para os camponeses. Em uma das sequências filmográficas há uma fileira em formato de meia-lua de mulheres novas e velhas, que entoam canções sérvias com os seios despidos. No momento em que há uma chuva, as mulheres correm para o campo e levantam as saias, para tentar recolher, por entre as pernas, em suas vaginas, a água que cai do céu fica clara a relação de rituais da fertilidade. Sua arte é forte, peculiar e se autoafirma, através dos múltiplos significados de ser artista, mulher, humana. Abramović busca nas suas raízes, em sua terra mãe, a força para se expressar.

Nos anos de 1980, muitas artistas resolveram dissociar suas biografias, das suas obras, fosse por uma frustração, fosse por uma vontade de mudar o foco temático. $O$ fato é que elas adotaram um estilo artístico conhecido por "arte de apropriação", ou seja, a inspiração vinha de fora, de imagens, situações, contextos diversos, tais como a história da arte, os meios de comunicação, publicidade e mídias diversas. Muitas voltaram-se para o lado mais irônico e humorista, mas sem deixar de abordar um conteúdo relativo à sua condição feminina, à identidade ou mesmo ao sexo. Era uma 
geração mais jovem de mulheres, mais autoconfiante das conquistas femininas. Nos anos de 1990, a fotografia obteve uma grande valorização como forma de arte independente (Grosenick, 2005). Cindy Sherman, por exemplo, apresentou-se como objeto artístico, colocando-se como modelo em suas fotografias, representando-se ora como mulher, ora como homem, em incontáveis personagens ou cenas descritas na história da arte, em telas do cinema e mídia. Rineke Dijkstra e Tracey Moffatt mostraram através de grandes fotografias seus modos de ver o mundo. Assim como outras tantas, elas usaram como tema de suas obras, sua identidade multicultural e a sua situação feminina em seus respectivos países de origem. Shirin Neshat, uma artista iraniana radicada nos Estados Unidos, mostra em fotografias e vídeos-instalação, de forma extremamente feminina e lírica, como são tratadas e vivem as mulheres em sua terra natal. As afro-americanas Kara Walker e Ellen Gallagher tratam em suas obras das questões que envolvem as discriminações sofridas pelas minorias étnicas, utilizando-se, muitas vezes, de fisionomias caricaturais dos negros. A carioca Adriana Varejão mostra, através da sua releitura da azulejaria portuguesa, o nosso passado histórico, o Brasil colônia, explorado e violentado por uma cultura escravocrata e opressora (Grosenick, 2005).

Algumas as recorrem, assumidamente, aos materiais e suportes ligados ao artesanato e ao trabalho manual, técnicas normalmente associadas à mulher; e o fazem mais como uma forma de provocação. Outras, incorporam os clichês femininos, mostrando a imagem da mulher da forma que foi tão comumente explorada, como o nu feminino. É o caso da italiana Vanessa Beecroft, que contrata modelos para posarem nuas ou com pouca roupa, durante horas, nas galerias e espaços expositivos. "Apresentadas em formação muito rígida, as modelos tornavam-se arquétipos abstratos de uma certa visão de beleza e perfeição" (Catálogo da 25a Bienal de São Paulo, 2002, p.407). O registro fotográfico desta atuação ou performance é também exposto como obra denominada de $\mathrm{VB}^{10}$. São fotografias

10 "VB" são as inicias do nome da artista Vanessa Beecroft. 
imensas que invadem nosso olhar e, muitas vezes, ficamos sem saber quem é o voyeur: nós ou a obra.

Bárbara Kruger fez um trabalho de cunho extremamente provocador e não circunscrito num espaço institucional, mandou estampar uma frase em sacolas de compras: "I shop therefore I am", ironizando a máxima de Descartes, como a sociedade de consumo. A artista fez uma forte crítica à sociedade e, especialmente, às mulheres que muitas vezes são influenciadas pelo poder da mídia e se deixam levar pelo encanto de consumir inúmeros produtos que supostamente as deixem mais belas. Ser significa ter. Nesse modo de pensar, quanto mais e melhores são os objetos consumidos e exibidos, melhor será a aceitação perante o social.

A paulista Sandra Cinto e a carioca Brígida Baltar têm em comum entre as suas poéticas, um olhar onírico perante suas próprias obras. Sandra Cinto, na década de 1990, iniciou sua carreira artística, representado pinturas de nuvens e céus dentro de caixas. Em suas instalações, a artista combinava objetos de madeira pouco previsíveis, como escadas, bilboquês, cavalinhos de balanço, cadeiras, mesas, estantes que na maioria das vezes eram pintados com cores claras, quase brancas. Os espaços e os objetos são quase sempre acompanhados de seus desenhos: pontes, abismos, candelabros, velas acesas, galhos e raízes de árvores retorcidos, estrelas, luzinhas, brilhos. A artista também insere, em muitas das suas instalações, fotografias da sua infância ou atuais, como o caso da instalação Sem Título. Segundo o professor e historiador de arte, Tadeu Chiarelli: "todos esses suportes ou elementos formam um ponto de encontro e difusão de infinitas narrativas, jamais concluídas, e comumente se configuram como soluções concebidas para espaços específicos." "11 Chiarelli ainda aponta que "em sua produção há obras em que sonho e realidade parecem coexistir em silenciosa e contraditória harmonia." ${ }^{24}$ Já Brígida Baltar trabalha

11 Cf. Chiarelli. Disponível em: http://www.itaucultural.org.br/aplicExternas/enciclopedia_IC/index.cfm?fuseaction=artistas_biografia\&cd_ verbete $=3271 \&$ cd_item $=2 \&$ cd_idioma $=28555$. Acesso em 20/07/08 às $21 \mathrm{~h}$. 
com a linguagem multimídia e capta suas ações através de registros fotográficos ou em vídeos, como foi o caso do projeto Umidades em que a artista recolhia o orvalho e a neblina, com base na coleta de elementos naturais e transitórios em áreas campestres. Nessas coletas Brígida capta uma memória afetiva do espaço, "como as lembranças de odores, da temperatura, dos sons e mesmo de sentimentos, como prazer, medo ou melancolia." Para o espectador, contudo, que tem acesso apenas as imagens fotográficas ou filmográficas, essas ações parecem realizar-se fora do tempo e do espaço, por estarem intrinsecamente ligadas à uma atmosfera de sonhos. ${ }^{12}$

Para todos os efeitos, as últimas décadas do século XX estão intensa e profundamente marcadas pela inclusão das mulheres no meio artístico e em todas as possíveis formas de expressão artística. Assuntos que antes eram tabu ou exclusivos para um nicho pensante (normalmente masculino), podem ser abordados abertamente por qualquer pessoa. Hoje, opta-se por falar ou não sobre os assuntos que pertencem ao mundo das mulheres. As artistas têm a liberdade de se expressar do modo que lhes aprouver.

A questão de a arte feminina permanecer um assunto central no século XXI - quer continuem a ser dedicados ao assunto livros inteiros, ou as artistas continuem a defender as suas posições num mundo ainda dominado pelo homem e a insistir em que a arte pode ser vista como uma afirmação distintiva de um individuo único, independentemente do gênero - permanece em aberto. (Grosenick, 2005, p.15)

Logo, este é um assunto extremamente vasto e aberto a outros tantos universos férteis para a investigação. Concentramos nossa pesquisa apenas em algumas poucas artistas selecionadas. Não

12 Comentário crítico da Enciclopédia de Artes Visuais do Itaú Cultural. Disponível em: http://www.itaucultural.org.br/aplicExternas/enciclopedia_IC/index.cfm? fuseaction $=$ artistas_biografia\&cd_verbete $=1286 \& c d$ _ item $=2 \&$ cd_idioma=28555. Acesso em 20/07/08 às $21 \mathrm{~h} 30$. 
devemos deixar de mencionar que esse tipo de escolha tenderá sempre para uma visão subjetiva e, consequentemente, unilateral. Os critérios utilizados foram essencialmente a afinidade conceitual, plástica e a pertinência dos posicionamentos com relação ao tema deste livro, ou seja, um recorte poético no universo artístico feminino no ocidente. 



\section{3 \\ As GERMINADORAS: \\ AS ARTISTAS (ES)COLHIDAS ATRAVÉS DOS RECORTES POÉTICOS}

\footnotetext{
"Semente é o símbolo das forças latentes, não manifestadas; das possibilidades misteriosas cuja presença nem se suspeita às vezes e que justificam a esperança. Também simbolizam o centro místico, o ponto que não aparece do qual se irradiam todas as criações e crescimentos da vasta árvore do mundo"
}

Jean-Eduardo Cirlot, Dicionário de símbolos

Neste capítulo, focamos apenas seis artistas que tiveram reconhecimento artístico no século XX. Essas mulheres têm em comum uma reflexão sobre questões do feminino através da sua arte.

Os caminhos que nos levaram até a escolha das artistas não foram simples atalhos. Escolher e colher quais artistas em um universo tão grandioso e diversificado como é o das Artes Visuais na contemporaneidade foi processo deveras complexo. Era preciso que essas sementes (es)colhidas germinassem processos frutíferos para a pesquisa. Os significados intrínsecos às obras dessas artistas deveriam estar, mesmo que subjetivamente, relacionados com a investigação sobre o universo feminino nas Artes Visuais. 
O caminho foi traçado, inicialmente, pelo que é mais caro nas Artes Visuais: a imagem e o tema. As escolhas partiram então dos entrelaçamentos das leituras que pudessem tecer afinidades entre a forma e o conteúdo das obras analisadas. Cada artista entrava por uma vereda distinta para chegar ao mesmo fim poético: o universo feminino. As (es)colhidas nesse processo foram:

- Frida Kahlo (México, 1907-1954). A (es)colha deveu-se ao seu modo visceral de mostrar o feminino através das suas pinturas onde ela expunha, entre outras coisas, a impossibilidade de realizar seu grande desejo da maternidade. A força do seu trabalho está na ligação entre a Pachamama e todas as mulheres.

- Louise Bourgeois (França, 1911). A (es)colha deveu-se à sua produção tão rica em conceitos e simbologias, através de uma sensibilidade delicadamente feminina. Por ser uma artista ainda atuante e com uma produção de grandiosa força, seria uma grande incoerência não incluí-la nesta etapa da pesquisa.

- Celeida Tostes (Brasil, 1929-1995). A (es)colha deveu-se à forte ligação entre sua vida e obra. Além de ceramista, Celeida era professora e dedicou sua vida para o ensino e a prática da cerâmica. Grande parte de suas obras estava diretamente ligadas à temática imagética das deusas da fertilidade do Paleolítico. Seu legado artístico deixou raízes profundas em todos que a conheceram - mesmo naquelas que não tiveram contato pessoal com a artista.

- Niki de Saint Phalle (França, 1930-2002). A (es)colha deveu-se ao fato do feminino ter se manifestado através das suas Nanas: grandes esculturas com formas femininas que ressaltavam seios, quadris, ventres como as estatuetas da antiguidade, porém mantendo uma linguagem contemporânea. Suas obras eram feitas geralmente para os espaços públicos e são extremamente lúdicas, coloridas e muitas vezes cinéticas e interativas.

- Judy Chicago (EUA, 1930). A (es)colha deveu-se à grandiosa obra The dinner party. $\mathrm{O}$ feminino apareceu na longa gestação coletiva que homenageou mais de mil mulheres de enverga- 
dura que, de alguma forma, não haviam sido reconhecidas pela história.

- Ana Mendieta (Cuba, 1948-1985). A (es)colha deveu-se em função da busca do feminino através de suas raízes históricas e pessoais, tal como Celeida e Frida. Suas performances em ambientes naturais evocavam a Pachamama de muitas maneiras e alertavam para a condição e força feminina.

\section{Frida Kahlo (México, 1907-1954)}

"Em algumas obras de Frida é clara a idéia de fusão, ela se funda com o outro, seja o outro Diego, portanto, o seu par amoroso, seja o outro a natureza, planta ou animal. Esta fusão é novamente conseqüência de sua busca identitária na medida em que explora os limites do corpo, a artista parece extrapolar os limites corpo humano em busca da unidade perdida nas inúmeras fissuras de sua coluna, de seu pé, enfim de seu corpo, fissuras impostas durante sua vida."

Simone Rocha de Abreu, Frida Kahlo e Ismael Nery

Frida Kahlo é uma artista latino-americana de grande reconhecimento e importância para a história da arte. Sua imagem, tão difundida no imaginário internacional, através de seus autorretratos, representava seus valores íntimos de modo extremamente visceral. Sua obra está calcada em um discurso subjetivo, criando uma espécie de fábula pessoal que mescla vida, sonhos, desejos, crenças e fantasias.

Frida nasceu na cidade de Coyoacán. Filha de mãe católica, mestiça de índio espanhol e de pai judeu alemão. A relação com sua origem mestiça povoou seu imaginário temático e foi um grande incentivo para uma constante busca identitária (Abreu, 2008, p.22).

Sua vida foi demasiadamente marcada pela dor e pela tragédia. Ainda criança, Frida foi acometida de paralisia infantil, deixando-a 
com uma deformação em uma das pernas. Em vista disso, ganhou o apelido de "Frida pata de palo" (ibidem, p.24) por mancar ao andar o que deixou marcas profundas em sua autoestima.

Entre 1924 e 1925, Frida frequentou o atelier do tipógrafo e amigo de seu pai, Fernando Fernández. Além do aprendizado com o tipógrafo, chegou a fazer algumas poucas aulas de desenho e modelagem em argila na Escuela Nacional Preparatória, no início da década de 1920. Até aquele momento, segundo consta em algumas de suas biografias, o contato da artista com a pintura tinha se limitado ao que aprendera com seu pai, através dos retoques fotográfi$\cos$ (ibidem, p.27).

Aos dezoito anos, em 1925, sofreu um grave acidente de ônibus uma das ferragens transpassou seu ventre, provocando várias fraturas na coluna vertebral, bacia e pernas. Frida passou um mês hospitalizada e ficou nove meses engessada da clavícula até a pélvis. As dores e incômodos desse acidente perpassaram toda a vida; ela jamais conseguiu recuperar-se totalmente. Foi neste período, que ela ganhou do seu pai uma caixa com material de pintura. ${ }^{1}$ Seus primeiros temas de desenho foram as imagens traumáticas do acidente. Não tardou muito para começar a pintar a si própria. Sua mãe teve a idéia de colocar um espelho pendurado sobre a cama de modo que a artista usasse a sua própria imagem como modelo. Sabe-se que ela passou muito tempo sozinha, deitada em sua cama enquanto se recuperava. O horizonte da enfermidade era transposto aos quadros, como um modo de se curar, desvanecendo as fronteiras entre a arte e sua fisiologia fragmentada. As constantes dores e cirurgias que passou durante sua vida foram temas recorrentes em sua obra - suas feridas expostas, a realidade e o desejo, dor e a esperança, o árido dia ensolarado e o frescor da noite enluarada. Em Árbol de la esperanza mantente firme, Frida mostra sua coluna ferida e a determinação de melhora após uma cirurgia de coluna: ela se mantém firme apesar da dor.

1 Era comum que os fotógrafos tivessem também prática com técnicas de pintura, uma vez que as fotografias eram em preto e branco, se faziam retoques com pigmentos para realçar detalhes ou corrigir falhas. 
Frida, engajada politicamente, filiou-se ao Partido Comunista. Foi lá que ela conheceu pessoalmente Diego Rivera, ${ }^{2}$ pintor muralista vinte anos mais velho que ela. Começou então, uma conturbada relação entre ambos, cheia de paixões e infidelidades. Em 1929, Frida acabou por se casar pela primeira vez com Diego. Esse turbulento casamento também apareceu como tema em muitas de suas pinturas, porém quase sempre de modo poético. Rivera era para Frida sua âncora e seu universo, seu impulso criador, sua terra firme. Frida o batizou de Espelho da noite: "Tu te chamarás AUTOCROMO, o que capta a luz. Eu, CROMORFO, a que dá a cor. Tu eras todas as combinações dos números. A vida." (Monsiváis apud Landucci, 2007, p.16, tradução nossa).

No final da década de 1930, Frida e Diego asilam em sua casa em Coyoacán, conhecida como La Casa Azul (hoje é Museo Frida Kahlo), Leon Trotsky e sua es. André Breton, com intuito de conhecer o revolucionário bolchevique, vai até o México e acaba por se encantar por Frida e sua obra. Por intermédio de Breton, que tornou-se seu amigo pessoal, expõe no ano de 1939 em Nova York e em Paris. Foi graças à ele também, que Frida conheceu os grandes artistas surrealistas e outros de renome, como Picasso, Miró, Kandinsky. Apesar de ter sido reconhecida por alguns crí-

2 Diego Rivera (1886-1957), pintor consagrado nacional e internacionalmente. Fazia parte do Movimento Muralista e era um dos Los Tres Grandes: Diego Rivera, José Clemente Orozco e Davi Alfaro Siqueiros. Os artistas através da sua arte, inundavam as paredes com imagens de denúncia da sociedade mexicana. O movimento ocorreu no início do século XX no México e influenciou não só os Estados Unidos da América, como também a Inglaterra. Os motivos que facilitariam a formação deste movimento foram as condições políticas favoráveis, além do fato dos mexicanos já terem uma tradição de arte mural advinda das culturas pré-colombianas (um retorno às raízes, portanto, uma forma de criar e reafirmar uma identidade mexicana). O então Ministro da Educação, José Vasconcelos, filósofo e revolucionário, tinha um projeto que dava total liberdade aos artistas com relação à temática e estilo nas pinturas. "Mais do que a fusão cultural mencionada acima, os muralistas, pelo menos em principio, exigiam a erradicação da arte burguesa (pintura de cavalete) e apontavam a tradição indígena como o modelo ideal socialista de uma arte aberta, para o povo "uma arte que fosse aguerrida, educativa e para todos" (Cf. Ades, 1997, p. 151-153). 
ticos como uma pintora surrealista, ela jamais se considerou como tal "Nunca pintei sonhos. O que retratei era a minha realidade" (Lehmann apud Grosenick, 2005, p.21). Nas pinturas que fazia de si mesma, Frida optava pelo jogo das substituições. Em seus autorretratos se concentravam sua sabedoria, seu amor, seus ressentimentos, suas criações da fauna e flora:

Certamente a alegoria, segundo helena Beristáin em seu Dicionário de retórica e poética, em um sentido mais profundo, Frida é o rosto que se apaga e ao mesmo tempo a emblematização da melancolia, da mulher cuja mascara é seu rosto verdadeiro, da criadora que se desconhece e se reconhece na superfície cristalina da tela, da solidão por necessidade e a força que de tanto estar consigo mesma precisa do desdobramento. "Sim é boa a água, beber / Sem perguntar pela fonte", escreve Juan Ruiz de Alarcón, e Frida poderia complementar: "Sim é grato o símbolo, veja-o / sem indagar pelo seu destino." (Monsiváis apud Landucci, 2007, p.13, tradução nossa)

Seu discurso apresentava-se cifrado nas suas obras, imagens de mulheres, animais e plantas gigantescas, nos fazem visitar um universo, o seu universo particular, "um éden subvertido onde o valor das formas depende da reação entre inocência e regresso à infância com olhos de reconciliação." (Monsiváis, Carlos apud Landucci, 2007, p.37). é pela representação da Terra (Pachamama) que a Tradição é mostrada: suas raízes, suas origens. Ela chega a retratar-se com trajes da sua etnia entrelaçada por raízes numa clara alusão à sua cultura, seu culto, seu colo. Como podemos perceber na obra Raíces .

Em algumas de suas obras, Frida mostra com toda sua dor e amargor, as perdas dos bebes que nunca conseguiu gerar, ${ }^{3}$ problema oriundo do acidente em sua adolescência. Na litografia El Aborto, 1932 a artista direciona nosso olhar e pensamento para o ciclo de procriação-vida-morte e ressurreição, como se fosse um códice. De cima para baixo, da esquerda para direita, como os ocidentais

3 Frida sofreu três abortos espontâneos entre 1930 a 1934. 
lêem os textos e também as imagens, é assim que se compõe a obra. A narração ocorre através do líquido amniótico: quando as células se unem e começa a gestação do feto que estava atado ao corpo de Frida no interior de seu ventre; o sangramento, lento e por muitos dias, que diluiu a existência do feto, o qual nutriu a semente da terra fecunda e esbanjou de plantas e tubérculos - cuja precisão lembra os tratados herbários coloniais - originando um novo ciclo de vida. Frida está nua e triste. Tudo ocorre frente a uma lua minguante, que chora pela tragédia.

Lo que el agua me dio, 1939 foi pintado enquanto ela esteve nos Estados Unidos com Rivera, logo após um outro aborto. Dentro da banheira, como se a artista juntasse suas memórias dentro da água (símbolo do inconsciente), estão suas heranças, suas raízes, suas vontades e desejos, sua vida explodindo num ciclo de nascimento e morte, o sofrido ciclo da vida.

Sua pintura era um meio de libertar-se metaforicamente da sua condição enferma. Toda a sua dor foi transfigurada em expressão plástica, a rotina das doenças, em afã criativo. Sua vida foi sua obra e sua obra foi sua vida.

\section{Louise Bourgeois (França, 1911)}

Disseram-me que existe uma boa dose de erotismo em meu trabalho. Bem, claro que existe, já que estou sempre interessada no corpo humano. Mas eu mesma não sinto esse erotismo. Minhas esculturas me agradam porque elas representam uma certa harmonia e uma certa ênfase, e eu não diria que o meu trabalho é erótico, mesmo quando esse lado parece óbvio para muitas pessoas.

Louise Bourgeois, Destruição do pai

As reminiscências traumáticas da sua infância, o confronto com o aspecto obsessivo de formas corporais, as emoções dicotômicas do cotidiano são para Louise seus principais objetos de pesquisa 
artística. A (re)construção da sua memória é o mote central de seus trabalhos, pois sua obra tem indubitavelmente uma dimensão autobiográfica. Assuntos como medo, amor, ódio, ternura, ciúme, culpa, proteção, agressão, sedução, traição, força ou vulnerabilidade são visceralmente explícitos em cada objeto ou instalação. "Bourgeois manifesta, do particular para o geral, durante os seus épicos setenta anos de produção artística, uma consciência profundamente humana (trágica e brutalmente cruel) da existência."4

A trama de sua linguagem é tecida com material do dia-a-dia. Sua prática contínua da escrita avança par a par com a do desenho. Louise Bourgeois está sempre desenhando, em qualquer superfície que lhe caia nas mãos. Ela chama esses desenhos de "pensamentosplumas". Linhas desenhadas e linhas escritas se entrelaçam para criar a tapeçaria das memórias da infância, e para exorcizar seus temores. Apesar do verdadeiro exorcismo ser conseguido somente na escultura, desenhar é uma atividade calmante e curativa, sobretudo durante as longas noites de insônia. (Bourgeois, Bernadac e Obrist, 2000, p.18)

É preciso começar pelo começo, pela genealogia de Louise, para entender sua obra, já que a própria artista afirma: "Tudo o que faço é inspirado no início da minha vida." (Bourgeois, Bernadac e Obrist, 2000, p.133). A mãe de Louise Bourgeois tinha um atelier de tapeçaria na cidade de Aubusson ${ }^{5}$ e foi lá que conheceu o marido. Segundo Bourgeois, o pai tinha um temperamento emotivo e irracional, enquanto sua mãe era sensata e paciente, por essa razão davam-se muito bem. Depois da $1^{\text {a }}$ Guerra a família se mudou para Paris, onde instalaram um novo atelier de tapeçaria. A mãe de

4 Cf. Afonso. Disponível em: http://artecapital.net/criticas.php? critica=154. Acesso em 22/09/08 às 8 h.

5 Cidade fundada por fabricantes de tapeçaria advindos da Bélgica e de Tournais no século XVI que perceberam as qualidades químicas especiais encontradas no rio Creuze (Bourgeois, Bernadac e Obrist, 2000, p. 117). 
Louise tingia lã e fazia restaurou em tapeçarias que fossem feitas apenas anteriormente a $1830 .{ }^{6}$ Foi nesse período que o pai "adquiriu o habito de achar outras mulheres atraentes. Minha mãe suportava suas escapadas e ele sempre voltava" (ibidem, p.117-118). Durante dez anos o pai teve um caso com a professora de inglês de Louise que morava com a família. A artista nunca entendeu o comportamento submisso da mãe, e para piorar, ainda se sentia usada pela própria mãe. "Então que papel desempenho nesse jogo? Sou um peão. Sadie supostamente está ali como minha professora e na verdade você, minha mãe, me usa para vigiar seu marido. Isso é abuso infantil" (Bourgeois, Bernadac e Obrist, 2000, p.134).

Com relação à sua formação acadêmica, Louise Bourgeois, iniciou seus estudos cursando matemática (cálculo e geometria) na Sorbonne. Não terminou este curso e acabou se enveredando em outras áreas: graduou-se em Filosofia na Universidade de Paris. Em meados da década de 1930, frequentou alguns cursos de arte, como a École dês Beaux-Arts (uma escola superior profissionalizante), Academie de lê Grande-Chaumière e École du Louvre. Trabalhou em ateliers de diversos artistas, incluindo Roger Bissière, André Lhote, Fernand Léger e no atelier de Mr. d'Espagnat. Após terminar o curso história da arte do Museu do Louvre tornou-se guia no mesmo local. Foi nesse período que conheceu Robert Goldwater, seu futuro marido, que na época fazia doutorado em história da arte. Em 1938 Bourgeois, já então casada com o historiador de arte norte-americano, muda-se com ele para Nova York. Nesta nova morada, Louise encontrou um ambiente artístico florescente e pôde continuar sua formação artística na Art Students League. Foi lá que ela se estabeleceu como artista, com exposições individuais, obras em acervos de museus, de galerias e de várias coleções particulares, assim como também teve seus trabalhos publicados em muitos livros de arte contemporânea. A artista adaptou-se tanto

6 Segundo a mãe de Louise, até 1830 as tramas de tapeçaria eram feitas com lã, depois começaram a utilizar algodão com tinturas químicas que desbotavam rapidamente (ibidem, p.119-120) 
ao país, que em 1951 tornou-se cidadã estadunidense (Bourgeois, Bernadac e Obrist, 2000, p.67 e 68)

Um dos seus primeiros conjuntos de obras foi feito em meados de 1940. As pinturas e desenhos intitulados Femme Maison eram representações de figuras femininas cujos corpos consistiam parcialmente numa casa. Com esta série podemos perceber a importância que a artista quis dar à situação social das mulheres naquele período, presas à sua condição feminina - especialmente se considerarmos que as mulheres na maioria das vezes, precisavam cumprir o papel de mães, esposas e donas de casa. é interessante notar que a casa está localizada na parte superior do corpo. O que poderia significar o quão as mulheres estariam presas ou encobertas, mental e corporalmente à esta condição.

Naquele tempo eu tinha apenas uma sensação, mas hoje compreendo claramente. Se você pergunta a alguém: "Você é homem ou mulher?", o que a pessoa deveria fazer? Simplesmente morrer de vergonha de que uma questão tão intima seja revelada ao mundo inteiro? A mulher que eu desenhava naquela época - a Femme Maison - ainda não tinha segurança ou objetividade para dizer simplesmente: "Não me pergunte isso!". Não. Ela fugia e se escondia. (Bourgeois, Bernadac e Obrist, 2000, p.114)

Louise também explica, num trecho de uma entrevista, que para entender o teor de sua obra, seria preciso interpretá-la como uma pessoa masoquista. Na mesma época em que fez as Femme Maison, ela estava com a sensação de que não poderia ter o direito de ter filhos ${ }^{7}$ e também não se sentia no direito de ser artista (Bourgeois, Bernadac e Obrist, 2000, p.160)

Na década de 1960, Bourgeois começou a experimentar alguns materiais como o látex, borracha, gesso e cimento. $\mathrm{O}$ tema ligado aos assuntos do lar, casa, família, foram abordados mais enfatica-

7 Bourgeois queria adotar uma criança, mas teve problemas por se mudar da França para os Estados Unidos. 
mente, como na obra Lairs (Tocas/Covil) - formas labirínticas, espirais, envolventes que geralmente abriam para um espaço oco.

Nos últimos anos, mesmo continuando a trabalhar com madeira, tenho voltado minha atenção para o gesso, o bronze e, mais recentemente, para o mármore. Continuei criando trabalhos de unidades fundidas e também assemblages. Antes de mais nada, minhas formas se tornaram ainda mais simples, mas suas relações se tornaram mais complexas. houve também uma mudança gradual da rigidez para a flexibilidade, e uma mudança da verticalidade ereta para formas espirais e estruturas que se abrem com um invólucro de pele para revelar ritmos internos. (Bourgeois, Bernadac e Obrist, 2000, p.77 e 78)

Nos anos de 1970, envolveu-se com o movimento feminista nos Estados Unidos. Neste período, criou The destruction of the father, 1974 uma grande instalação que possuía formas viscerais, arredondadas e avermelhadas que avançavam de forma ameaçadora em cima do observador, como se o interior (as entranhas) tivesse sido exteriorizado. Esse trabalho evidencia seu desejo infantil de destruir / devorar o pai - Louise nunca se conformou com o comportamento infiel dele, criou uma escultura que tinha raízes na sua fantasia infantil de devorar o pai.

The destruction of the father [A destruição do pai] (1974) lida com o medo - do tipo comum, o medo verdadeiro e físico que ainda hoje sinto. O que me interessa é a conquista do medo, o esconderse, a fuga dele, o enfrentamento, o exorcismo, a vergonha dele, e finalmente o medo de sentir medo. é esse o tema. [...] Bem, o objetivo de The destruction of the father era exorcizar o medo. [...] Então o motivo para fazer a peça foi a catarse. (Bourgeois, Bernadac e Obrist, 2000, p.157)

Louise continua seu relato descrevendo o desejo de devorar seu pai durante as refeições, quando ela, os irmãos e a mãe eram obri- 
gados a ver o pai se exibir e se enaltecer: "E quanto mais se exibia, menores nos sentíamos. De repente havia uma tensão terrível e o agarramos - meu irmão, minha irmã, minha mãe -, nós quatro o agarramos, o deitamos na mesa e arrancamos suas pernas e seus braços - o desmembramos, entende?" E a fantasia segue com o ato de devorar: "E tivemos tanto êxito em espancá-lo que o comemos." The destruction of the father é uma obra que originou-se da agressão emocional, deslocamento, desintegração, explosão e total destruição ou assassinato. Mas no polo oposto estão obras pacíficas. Depois de tanta emoção, ela representa uma busca, não de paz, mas realmente de perdão e esquecimento (Bourgeois, Bernadac e Obrist, 2000, p.101)

A necessidade interior do artista de ser artista tem tudo a ver com gênero e sexualidade. A frustração da artista mulher e a ausência de seu papel mais imediato como artista na sociedade são resultados dessa necessidade, bem como sua falta de poder (mesmo quando ela obtém sucesso) é conseqüência dessa vocação necessária. Nós não escolhemos nosso papeis - nós obedecemos ao chamado e aceitamos seus termos -, o que obviamente não significa que não nos ressentimos deles. Isso não está totalmente claro; nós nos tornamos escultoras, digamos, por causa da nossa incapacidade de crescer (o que é uma graça disfarçada), porem é fato que permanecemos mendigas por toda a vida. Bem, podemos conversar a respeito, e, a despeito de todas as nossas frustrações, manter boas maneiras. (Bourgeois, Bernadac e Obrist, 2000, p.100)

Somente em 1982, Bourgeois então com 71 anos, teve sua primeira maior retrospectiva organizada pelo Museu da Arte Moderna de Nova York (MoMa). Foi a primeira vez na história do museu que se fez uma homenagem a uma única artista mulher. Anos mais tarde, em 1985, a artista realizou sua primeira exposição individual na França (uma retrospectiva de 1947 a 1985), na Galeria Maeght Lelong, em Paris. Em 1989 consolidou-se na Europa com exposições no Frankfurt Kunstverein e com a partici- 
pação da Documenta IX de Kassel em 1992 e na Bienal de Veneza em 1993.

Louise desenvolveu uma série, iniciada na década de 1980, em que a presença da dor e da agonia eram marcantes. Eram instalações em que a artista deu forma mais uma vez a toda frustração e sofrimento de sua infância. Cell (Arch of hysteria), Precious liquid, Cell (Glass Spheres and hands), Cell (You Better Grow Up) são enigmáticas instalações que, ao mesmo tempo nos convidam a entrar, nos repelem por serem claustrofóbicos e asfixiantes. Segundo a artista:

As Cells [Células] representam diferentes tipos de dor: as físicas, as emocionais e psicológicas, e as mentais e intelectuais. Quando o emocional se torna físico? Quando o físico se torna emocional? é um círculo girando sem parar. A dor pode começar em qualquer lugar e virar em qualquer direção. Cada uma das Cells trata do medo. Medo é dor. Muitas vezes não é considerado dor, porque está sempre se disfarçando. Cada uma das Cells trata do prazer do voyeur, a excitação de olhar e ser olhado. As Cells podem ser atrair ou se repelir umas às outras. Existe essa necessidade de integrar, fundir, ou desintegrar. (Bourgeois, Bernadac e Obrist, 2000, p.157)

Em uma entrevista, Louise revelou que a obra Precious liquids possuía um subtítulo que encontrava-se gravado em uma placa de aço na entrada da instalação com os dizeres: "A arte é uma garantia de sanidade." Sobre as formas de vidro que pairavam sobre a sala e a cama, Louise explicou que elas se referiam aos fluxos líquidos liberados pelo nosso corpo, tanto em momentos de tensão, como em momentos de relaxamento ou prazer. "Nesta peça o líquido é sugerido pela formas de vidro; algumas são fechadas como gotas e outras, abertas como funis, são metáforas dos músculos do corpo." O casaco representa uma figura masculina, um voyeur e dentro dele há um vestido branco de uma menina de cerca de doze anos. 
Está bordado neste vestido "mercy merci" [ mercy = compaixão em inglês; merci $i$ obrigado em francês]. O tema desta obra envolve "a história do inconsciente - você tem de suportá-lo e, se for talentoso e generoso o bastante, e se gostar de si mesmo o bastante, chegará a um acordo com ele." (Bourgeois, Bernadac e Obrist,, 2000, p.234 a 236)

Temos o suor, as lágrimas, o muco, a saliva, a cera do ouvido, a bílis, a urina, o leite, o pus, o sêmen e o sangue. A peça Precious liquids (1992) é sobre uma menina que cresce e descobre a paixão em vez do terror. Ela pára de ter medo e descobre a paixão. O vestidinho que se refugia no casacão representa a criança que passou por emoções fortes e assustadoras. O casacão é uma metáfora do inconsciente. Ela se refugia do mesmo modo que os artistas se refugiam no inconsciente. Estou em paz com meu inconsciente. Confio nele, posso achá-lo embaraçoso, mas não posso estar enganada. (Bourgeois, Bernadac e Obrist, 2000, p.255 e 257)

Já na obra Cell (Glass spheres and hands), o vidro simboliza o grau de fragilidade que há em uma pessoa. As bolhas são transparente e encerradas em si mesmas, são intangíveis. "é uma situação muito pessimista. Suponha que eu queira que uma pessoa me ame e - ela é uma bolha, eu não tenho acesso. Sou incapaz de me fazer escutar ou amar." As cinco bolhas de vidro estão dispostas em cima de cadeiras, ao redor de uma mesa, onde há uma escultura em mármore de duas mãos entrelaçadas: "Eu cerro minhas mãos em desespero. Os artistas não são ensinados, são feitos, acontecem por acaso; então me desespero porque não tenho impacto sobre eles." (Bourgeois, Bernadac e Obrist, 2000, p.237)

Em Cell (You better grow up), Louise descreve o ambiente como uma cela de dois por dois metros. Ela tanto pode ser uma prisão como uma célula biológica. Suas delimitações são feitas com grades de ferro e vidro. Dentro há espelhos, que giram no sentido vertical e horizontal, um bloco de mármore rosa com três mãos escavas nela. 
há também três mobílias de madeira onde se encontram uma torre de vidro, três frascos de perfume, um recipiente de cerâmica com três aberturas e várias formas de vidro. "As três mãos são uma metáfora da dependência física. A mão maior segura as duas menores, infantis, como para protegê-las." A mão menor representa as mãos da própria artista. Os espelhos servem para dar uma visão múltipla do mundo, pois se sobrepõem. "Os frascos de perfume nos botam num humor nostálgico, com a poderosa lembrança acionada pelos perfumes. Em nossa recusa a enfrentar o medo, recuamos para a nostalgia." As formas de vidro e de cerâmica são para a artista autoindulgentes, "uma forma de romantismo, um estado de abandono, uma postura de laissez-faire, um sonho infantil. São as coisas que fazemos sem ter de enfrentar as consequências." Ainda sobre sua obra, Bourgeois fala que: "o mundo que é descrito e realizado é o mundo assustador de uma criança que não gosta de ser dependente e sofre com isso. Por isso a moral desta Célula: é melhor você crescer." (Bourgeois, Bernadac e Obrist, 2000, p.231)

Essas instalações, cujo desconhecido estado de vazio provoca a memória, fazem sentir a constante presença de uma preocupação, uma obsessão, uma tensão, como um reflexo da obscuridade da alma. Louise dá forma à frustração e ao sofrimento, sentimentos que são humanamente universais. é por esta razão que conseguimos nos projetar dentro da obra, vivenciá-la. Parece-nos que ela quer organizar o seu caos interno com essas construções e objetos.

Mais recentemente, Louise desenvolveu uma série intitulada Spiders. Assim como as Cells, estes trabalhos são investigações psicológicas. De acordo com a própria artista, a aranha é uma duplicação da natureza maternal, pois sua seda é usada tanto para fazer os casulos, quanto para as teias (casa). As colossais Spiders, se sustentam em pernas finas e longas, que podem nos remeter aos arcos botantes das catedrais góticas. Suas aranhas carregam uma espécie de bolsa sempre cheia de ovos em seu ventre (feitas em mármore). Elas nos assustam pelo tamanho e pelo que representam, mas ao mesmo tempo nos sentimos protegidos embaixo de uma espécie de 
grande mãe acolhedora. Com essa série, a artista quis prestar uma homenagem à sua mãe.

Louise se preocupava com a idéia de que talvez sua mãe não a amasse, coisa que ela não suportaria. Na escultura She-fox, feita em mármore preto com um metro e oitenta de altura, o feminino é exposto através dos vários seios frontais. A raposa está agachada, há um corte no pescoço e a cabeça está decepada. Sob as ancas numa espécie de ninho, encontra-se um rosto da série Fallen woman (que, segundo a artista, seria ela própria). A raposa representaria sua mãe: "uma pessoa muito inteligente, paciente e obstinada, talvez calculista." Para Louise a mãe era uma raposa, pois era alguém que lhe exasperava e a impelia à violência, por essa razão ela a decepou e cortou-lhe a garganta. "Ainda assim espero que ela goste de mim. A tragédia é: uma pessoa que tratei desse modo pode gostar de mim? Entende?” (Bourgeois, Bernadac e Obrist, 2000, p.140)

As inúmeras formas arredondadas, espiraladas, formas sexualizadas ou erotizadas que oscilam entre o formato masculino e o feminino, criam a noção de movimento circular contínuo em que se inscreve a dor, rodeando-nos e invadindo-nos intensamente. Suas obras oscilam entre a dicotomia do ameaçador e do vulnerável. Falam sobre os sentimentos, memórias, impressões de uma mulher artista e contemporânea. Ao ser indagada se ela tratava das questões a cerca dos sentimento de uma mulher ou se era um estado humano mais geral, a artista respondeu: "Eu sou uma mulher! Como posso ter os sentimentos de um homem? [...] Mas, nunca, nunca, nunca tive a intenção de falar por um homem. Seria muito presunçoso." (Bourgeois, Bernadac e Obrist, 2000, p.269)

As conexões que faço em meu trabalho são conexões que não posso encarar. São na verdade conexões inconscientes. $\mathrm{O}$ artista tem o privilégio de estar em contato com seu inconsciente, e isso é realmente um dom. é a definição de sanidade. é a definição de autorealização. (Bourgeois, Bernadac e Obrist, 2000, p.367)

Louise vive, sobrevive e recria-se através da sua arte. 


\section{Celeida Tostes (Brasil, 1929 - 1995)}

Seguindo a mitologia, o nome de Celeida, como o conjunto de sua obra, significa o que abre caminho através do BARRO. Obra mais que aberta, ela tem contudo definições e parâmetros muito bem definidos. Tanto biográficos como estéticos, sem quaisquer etiquetas ou modismos.

Obra de raiz, rima com alma de barro. A primeira impressão é a de que sua aparência traz aquela crueza da topologia da terra e a vitalidade da natureza argilosa do solo.

Magia totêmica e fertilidade de Tempo de Trabalho: reunião pictográfica de Celeida...

Clóvis Brigagão ${ }^{8}$

Celeida tinha apenas um ano e um mês de vida, quando perdeu a mãe e, em consequência disto, foi para fazenda dos avós em Macuco, no estado do Rio de Janeiro, lugar onde passou toda sua infância. Seu pai, devido ao trabalho com comércio exterior, passava a maior parte do tempo longe e pouco via a filha. Mas, apesar disso, Celeida confessa que teve uma infância feliz, cercada de muita liberdade, brincadeiras e primos. A esse respeito a artista declarou certa vez: "Uma coisa danada! Muita coisa boa, muita coisa assim de vida, por exemplo: os cheiros da fazenda, os cheiros da cozinha, o cheiro da época de jabuticaba, da geléia disso, da geléia daquilo" (Tostes apud Pinto, 1994, p.69-70).

Sua memória da infância, como podemos observar, foi cheia de vida e plenitude e manifestou-se fortemente em sua fase adulta, nas escolhas profissionais como artista plástica e educadora, retornando às suas raízes, ao "seu" barro. Nesse depoimento, apesar dela ex-

8 Cf. Brigagão apud: Tostes. Disponível em: http://www.itaucultural.org. $\mathrm{br} /$ aplicExternas/enciclopedia_IC/index.cfm?fuseaction=artistas_criticas \&cd_verbete $=1380 \& c d \_i t e m=15 \& c d \_i d i o m a=28555$. Acesso em: 13/08/08 às $14 \mathrm{~h} 21$ 
plicitar a importância da sua formação acadêmica com seus grandes mestres no Brasil e no exterior, fica evidente o quanto sua infância na fazenda, brincando com barro e a terra, influenciou na escolha de sua trajetória artística - ela tornou a apropriar-se do material que lhe foi tão presente:

Não houve nenhum professor, nenhuma pessoa que tivesse me estimulado especialmente para as Artes Plásticas. Porém, desde criança eu gostava de mexer com coisas e o espaço da fazenda foi sem dúvida alguma estimulante. Tanto que, depois de muitas idas e vindas, eu voltei para a cerâmica. Voltei para um material que existira com muita presença na minha infância. Cursei Artes Plásticas na Escola Nacional de Belas Artes, onde fui aluna de Goeldi e de outros também da mesma forma importantes. Fiz cursos de aperfeiçoamento nos Estados Unidos e no País de Gales, onde tive professores famosos. Neste último, fiz um estágio a nível de pósgraduação com experiências inusitadas. (Pinto, 1994, p.75)

Tanto nos Estados Unidos (Universidade de Southern Califórnia), quanto no País de Gales (School of Arts do Cardiff College), Celeida recebeu bolsa de estudos dos respectivos países para fazer seus cursos. Ainda com relação à sua formação, ela fez uma pós- graduação no Departamento de Desenho Industrial na Escola de Belas Artes da Universidade Federal do Rio de Janeiro - EBA/ UFRJ em 1987, além de lecionar no núcleo 3D da Escola de Artes Visuais do Parque Lage - EAV/ Parque Lage, desde 1976, e na EBA/UFRJ (Figuras 56 a 60), onde obteve livre-docência.

Quando atentamos à descrição de sua formação, vemos o quanto sua atividade criadora estava constantemente conectada ao seu universo mágico da infância, das brincadeiras livres e soltas em uma fazenda do interior, um imenso quintal repleto de descobertas que a levaram até um universo imagético, manifestado em toda a sua obra. Sabemos, porém, que isto não foi privilégio apenas dela, uma vez que o universo simbólico de qualquer artista começa a se modelar na infância. 
A artista tinha plena consciência de seus processos criativos nesse trecho que se segue, ela faz uma descrição de como encarava a criação artística, reforçando que isso só poderia acontecer se nós permitíssemos que os sonhos e fantasias conseguissem emergir do nosso inconsciente:

[...] Qualquer matéria, através do próprio processo que gera, oferece imagens que irão funcionar como indicadores os quais levantarão questões a ela pertinentes a serem selecionadas e, ou, aprovadas. Mas só se as pudermos VER, não apenas com o nosso aparelho de olhar, mas com todos os sentidos, com os ingredientes da fantasia, do sonho, da ousadia, lembrando que mais do que considerar erros, é preciso considerar as questões que se colocam. Cada matéria traz uma mensagem sensorial e deve ocasionar um diálogo. (Pinto, 1994, p.80 e 81)

A produção plástica de Celeida estava intimamente ligada com a natureza matérica do barro: basta que tenhamos conhecimento de como se trabalha com a argila, pois devemos colocar todo nosso corpo e energia para ação de sovar, amassar, bater o barro, até que ele esteja pronto para ser modelado. ${ }^{9}$ Suas obras são fortes e grandiosas (mesmo sendo pequeninas, por serem em grande volume, tornavam-se monumentais).

Como artista e como mulher, Celeida conseguiu unir sua vida à sua obra. Suas ações e projetos foram bem mais longe do que indagações acerca das questões femininas, ultrapassando inclusive a esfera educacional, chegando até mesmo a um âmbito social. ${ }^{10}$

9 A argila deve ser sovada para ficar livre de bolhas de ar (que são uns dos grandes motivos de quebras e rachaduras nas peças durante a queima), pois o ar quando aquecido expande-se e, se não há lugar por onde ele circular. Portanto, sua expansão pode ocasionar a quebra total da peça, ou simplesmente provocar fissuras que podem danificá-la consideravelmente.

10 Celeida Tostes implantou um projeto social no Morro do Chapéu Mangueira no Rio de Janeiro, denominado de Centro de Cerâmica Utilitária, que consistia em um galpão onde era ensinando gratuitamente a técnica da cerâmica aos 
O levantamento do memorial cultural no Morro do Chapéu Mangueira é de fato a expressão da capacidade criadora individual e coletiva simultaneamente. A primeira, através daquilo que o individuo é enquanto sujeito. A segunda, naquilo em que ele traz com ele de suas tradições sociais de origem. Uma resposta concreta e autentica de vivencias presentes e anteriores, procurando excluir influencias da cidade grande. (Pinto, 1994, p.84)

A performance Passagem, de 1979, foi realizada no apartamento da artista, no Bairro de Botafogo no Rio de Janeiro. O cômodo foi devidamente preparado para o evento: esteira e barro no chão, panos brancos nas paredes, dois jarros e alguns tijolos. Como performance, o trabalho transita entre as artes plásticas e cênicas. O que hoje temos como registro dela são as fotografias de Henri Stahl. A sequência das imagens mostra-nos como um filme todas as etapas que a artista passou para realizar a obra.

Concordo com os críticos que dizem ser Passagem o meu trabalho matriz - ele foi uma tentativa de voltar ao útero de uma mãe que não conheci. Tem uma ligação muito forte com minha história de vida. Surgiu após uma fase em que eu estava fazendo bolas, fazia bolas que não acabava mais e, colocava coisas dentro delas, coisas que faziam uns barulhos. Então me dei conta de uma lembrança da fazenda, de uma antiga empregada que dizia que os bebês apareciam no canteiro de repolhos. Ate hoje não sei como esta lenda européia chegara aos ouvidos dela. Logo começaram a vir uma série de memórias, como por exemplo, uma prima grávida e nós, crianças, destroçando um canteiro de repolhos para procurar o seu bebê.

moradores. Com sua didática à la Paulo Freire (a alfabetização era feita a partir do universo de palavras dos educandos), da mesma forma, Celeida resgatou o "vocabulário" da argila dos moradores, que mesmo sem ter consciência, trouxeram imagens e objetos de um passado, de uma infância que muitas vezes fora vivida num outro local (migrantes, por exemplo, do nordeste que se utilizavam de tigelas, potes, jarros e xícaras de cerâmica artesanal em seu cotidiano). 
Mas, eu ainda levei muito tempo, cerca de dois anos, para conseguir realizar Passagem. (Pinto, 1994, p.92)

Celeida continuou a explanação, frisando que ela já havia frequentado anteriormente sessões analíticas e que, inclusive, já havia terminado as de psicodrama. Ela ainda afirmou: "Mas eu tenho conhecimento de que no livro rolou outras sessões de análise, tal a força de suas imagens. Todavia, a Passagem foi muito mais do que isso. Foi como se eu tivesse saído e ido embora para o espaço. Foi além do útero, com certeza." Seus amigos que acompanharam e ajudaram durante a performance e o etnólogo que fotografou, Henry Stahl, não ouviram palavras, apenas sons. Celeida exprimiu suas sensações da seguinte forma: "E eu podia ter sido uma pedra, podia ter sido um bicho, qualquer coisa, um vegetal, um animal, um mineral, qualquer coisa. E era além do ventre. Após esta experiência fortíssima, quase não consegui falar sobre o que se havia passado. Apenas escrevi:" (Pinto, 1994, p.92 e 93)

Despojei-me. Cobri meu corpo de barro e fui. Entrei no bojo do escuro, ventre da terra. O tempo perdeu o sentido de tempo. Cheguei ao amorfo. Posso ter sido mineral, animal, vegetal. Não sei o que fui. Não sei onde estava. Espaço. A história não existia mais. Sons ressoavam. Saíam de mim. Dor. Não sei por onde andei. O escuro, os sons, a dor, se confundiam. Transmutação. O espaço encolheu. Saí. Voltei. (Pinto, 1994. p.92 e 93)

Celeida com Passagem envolveu-se totalmente na argila, seu corpo tornou-se barro. Ali ela se entregou e se aprofundou em sua essência humana e mítica: no mito, Prometeu modelou os seres humanos a partir do barro; no mito cristão, os humanos foram feitos da terra, do pó.

Assim, Celeida evocou o poder do feminino, da Terra, da $\mathrm{Pa}-$ chamama. Ela, agrupada pelo barro do jarro/útero, gerou uma nova vida, uma nova artista. Como num ancestral ritual de passagem, a artista criou (re)significados e (re)significou-se. Na pequena 
fenda do jarro e de dentro de sua morada, a artista renasceu, floresceu, germinou e brotou muitas sementes em forma de arte.

Celeida, a grande sacerdotisa do barro, nos rende uma homenagem. Renasce. Como Deméter, deusa da fertilidade, liberta-se de Hades, e traz consigo, do fundo da terra, Perséfone e todas as flores do universo. Faz-se primavera. Celeida morre / renasce como a natureza. Celeida doce. Celeida meiga. Celeida frágil. Celeida generosa. Celeida firme. Celeida determinada. Num jardim cheio de barulho e vozes, rosas e lírios se misturam a crianças. Bonecas, estatuas, odores, barro. Lama, sinfonia de formas. Um anjo de branco canta saudades. O céu casou-se com a terra. Esta noite estaremos todos juntos no grande banquete dos deuses. (Gutmacher apud Costa, Marcus de Lontra. Arte do fogo, do sal e da paixão - Celeida Tostes. Rio de Janeiro: CCBB, 2003, p.43)

Celeida trazia à tona um universo imagético ancestral e extremamente profundo com suas cerâmicas. A artista tinha feição arqueológica, explicitada em muitas de suas obras. O poder da Grande-Deusa manifestava-se entre as fendas, passagens, vulvas. Na obra Guardião, encontrada no seu atelier na EBA/UFRJ, fica claro a manifestação desta força ancestral, na forma de um grande quadril com uma espécie de cabeça fálica. Essa obra é facilmente comparável às suas pequeninas Vênus, por manter, na simplicidade de suas formas, o que é intrínseco aos corpos feminino e masculino: a redondeza das extremidades sexuais. Os genitais - falos, vaginas, seios, nádegas, ventres - são sugeridos de modo puro e singelo, mas sem deixar de lado um toque de sensualidade.

A feminilidade e fertilidade se manifestavam também através de suas quatrocentas esferas, nas Mil bolas e Vênus, nos Dez mil ovos. Segundo a própria artista, "no Paleolítico Superior, o nascimento das 'Vênus', ao que se tem configuração até agora, deu-se no bojo das mãos. Como se a mão fosse o ventre." Ela continua a magnífica comparação: "Assim, o aperto reflexo da mão no material mole, que também é relação de magia, relação com o corpo da mulher, 
com a agricultura ou com a fartura, deu origem às Vênus." (Pinto, 1994, p.75)

Celeida é uma artista de uma só fase: cada vez mais longe, cada vez mais fundo. Distanciando-se da superfície convencional, a sua matéria-prima, o barro ancestral, despoja-se lentamente da rima visual para procurar febrilmente a sensualidade da mão se espojando na maciez untuosa. Potes. Potes fechados, promessas pudicas, ciumentas, herméticas. Um dia a sua espera e clama. Vazio matriz, forno, útero. é a crise. Vida e arte se confundem. Em ritual de passagem, Celeida refugia-se num útero de barro, e, quando este se rompe, fecundo, expulsa a cria e a placenta para uma nova vida, suja e perdoada. Pela abertura das bolas, antes vazias, fetos nos espreitam, já sexuados, futuros continuadores da espécie. (Stahl, 1991, p.195-196)

Com todo direito que uma mestra do barro possui, Celeida apropriou-se de algumas casas de joão-de-barro, para compor ainda mais seu universo feminino. Este pássaro constrói seu ninho com uma mistura de barro, galhos e sua própria saliva. A fêmea fica dentro da casa/útero para chocar seus ovos. é o macho que se responsabiliza por alimentar a fêmea e os filhotes. Muito semelhante ao padrão que a humanidade adotou durante séculos.

A obra Aldeia Funarios Rufus foi uma instalação feita com as casas de joão-de-barro originais e as que a artista produziu, ovos de cerâmica, roda de cerâmica, pequenas peças na parede, terra, dispostos no chão. Todas as quarenta e cinco peças de joão-de-barro possuíam uma abertura, como se fosse uma entrada para a pequenina caverna. Em algumas delas haviam ovos de cerâmica, outros estavam vazios, desabitados.

A exposição em que estava a Aldeia Funarius Rufus chamava-se Tempo de Trabalho e aconteceu em 1990 na Escola de Artes Visuais do Parque Lage (EAV - RJ). Junto à instalação Celeida escreveu um texto, explicando e descrevendo a idéia da instalação: "Funarius Rufus, arquiteto, chamado de passarinho pedreiro, oleiro, amassa barro, forneiro, Maria de barro - é o joão-de-barro. Mo- 
nógamo. Conta a lenda que enterra na própria casa a esposa infiel. Cor avermelhada, mede em torno de vinte centímetros." O macho e a fêmea, constroem juntos a casa durante cerca de 5 dias, para procriarem. "Trabalham cantando. Seu canto é uma gargalhada. Carregam ao todo quatro a seis quilos de barro. Amassando, carregando com o bico e colocando cada bolinha ao lado da outra, formando um cordão em espiral que vai subindo até completar a casa." Celeida continua:

Povos primitivos dispensavam grande respeito ao joão-de-barro. Acreditavam que era enviado por Deus para ensinar-lhes a construir suas casas, a fazer seus potes, seus fornos de pão. Oleiro, conhecedor de seu ofício, construtor capaz, sabe bem dos materiais com que trabalha. Precisa da chuva para amolecer o barro, mas se o barro seca, constrói a casa com bosta. Suas diversas enzimas ligam e dão força ao barro ou à bosta. Queimada, a casa perde sua força. Algumas casas desta aldeia foram queimadas. Outras construídas seguindo a analise química do material, empregando-se o mesmo capim e a saliva colhida de diversas pessoas, partindo-se do pressuposto das diversas enzimas fabricadas pelo joão-de-barro durante o seu trabalho. Quando os filhotes já voam a casa é abandonada. Nunca mais o joão-de-barro volta a ela. Outros pássaros podem ocupar a casa vazia, até serpentes. Em cada primavera, uma nova casa é construída. Para continuar a espécie. (Tostes, Celeida apud Pinto, 1994, p.100 e 101)

Esses pequenos ninhos, as pequenas casas de joão-de-barro, justapostos de modo a parecer como uma pequena cidade foram inspirados num modelo de aldeia Xavante que é arquitetada em formato de espiral. é, portanto um espaço de comunhão, de encontro, de núcleo, que está intrinsecamente ligado aos nossos conceitos de cultura e identidade ancestrais. é também o espaço mágico, instalado através de uma poética sensível, que traduz os múltiplos significados de cidade / aldeia como lugar de troca. Lugar que mescla tecnologia com procedimentos arcaicos, "a artista experimentou a saliva de diversas pessoas para alcançar a tecnologia do joão-de-barro e, ao mesmo 
tempo, queimou a casa do pássaro, constatando que a troca não dava certo e tendo afirmado: "Cada um na sua!" (Pinto, 1994, p.73)

O espaço público, em contraposição com o privado, é também reflexo da ampliação das conquistas femininas. A cidade e as tecnologias atuais que são frutos da racionalidade humana devem ser locais de encontro e comunhão com a feminilidade, com a leveza, o sonho, a poética. Uma nova maneira de ver a cidade.

Com a Série Rodas, a grande roda vermelha chama atenção ao lado das multicoloridas rodas menores. As pequenas peças, fixadas na parede junto com a "roda gigante" nos remetem a um tabuleiro de um jogo. Um jogo visual, obviamente, em que as peças devem ser movidas, rodadas, apenas em nossa cabeça, através da contemplação.

A Série Selos é um conjunto de mil pequenas peças, em que Celeida criou um vocabulário próprio de imagens (letras), com diversas cores de argila. Estes selos foram concebidos como gravuras, podem ser vistos (lidos) como uma antiguíssima biblioteca, cheia de múltiplos e mágicos significados.

Um de seus grandes desafios, dizia a própria artista, era sair da horizontalidade e fazer com que o pequeno se tornasse grande. A verticalidade era buscada através da repetição, até que esta conquistasse um espaço, mesmo que fosse através da fragmentação "da memória de uma imagem do imenso. Os 10 mil ovos, as mil bolas, os úteros, as mil Vênus e ferramentas, as casas de joão-de-barro (cavernas, aldeia), os mil selos, os tijolos de adobe.[...] No entanto, meu espaço permanecia horizontal." Ela afirmava que: "Subir era uma dura tarefa. Meu material brigava com a verticalidade e, meu corpo, para o alto, não alcançava muito. E o fogo? Como queimar? Comecei desenfreada a misturar pós." Porém seus esforços para fazer tijolos sem queimar foram em vão. Celeida, sem desistir, persistiu contando com a bagagem das experiências anteriores: as casas de joão-de-barro e o morro Chapéu Mangueira:

Tinha que ser uma massa forte. E crua. Consultei Coaracy, mestre-de-obras do Chapéu Mangueira. Experimentando, entrei no universo mais amplo dos materiais cerâmicos. O fogo já não fazia falta. A matéria fora encontrada, mas meu corpo não servia à 
dimensão que a matéria já resolvera. Quase escalava meu próprio trabalho. Na luta corpo a corpo com os tamanhos senti a necessidade da ajuda. Procurei os amigos, a favela. O morro do Chapéu Mangueira, mais uma vez, participa do meu trabalho. Corpos em movimento acrescentavam à obra uma energia que se somava à minha. Para irem para o Parque Lage minhas esculturas, ainda com as estruturas expostas, saíram do meu espaço, da minha casa e ganharam a rua Jardim Botânico, num grande mutirão que mais se assemelhava a uma alegre procissão. (Tostes, Celeida apud Costa, 2003, p.62)

Um ato de celebração e comunhão. Para Celeida, esse era o verdadeiro intuito do fazer cerâmico.

\section{Niki de Saint Phalle (França, 1930 - 2002)}

A poética dos trabalhos de Niki de Saint Phalle é bastante particular, seu universo é repleto de seres fantásticos, monstros, personagens femininos e coloridos. Todos esses elementos aparecem nas arquiteturas espontâneas, ${ }^{11}$ no qual podem ser encontrados diversos desses elementos [...].

Carmen Cecília Cabañas, A arquitetura de Niki de Saint Phalle

Niki de Saint Phalle nos apresenta uma outra vertente de trabalho, adentrando em um universo mágico, colorido, lúdico e monumental. Sua vida e, de certa forma, sua obra, foi marcada por um acontecimento trágico: aos 11 anos sofreu abusos sexuais por parte

11 Segundo o professor e arquiteto Fernando Fuão, a definição de arquitetura espontânea seria: "as arquiteturas que se afastam do habitual e andam fora do lugar, se apresentam como algo totalmente desencaixado do sistema de compreensão da arquitetura tradicional. A maioria dos arquitetos esquece que o fenômeno está diretamente relacionado com a imaginação, com a criatividade e com a fantasia e que, de certa forma, não é divergente do pensamento tradicional-racionalista" (Fuão apud Cabañas Pedro, 2008, p.32). 
do pai. Essa situação desencadeou uma série de problemas emocionais e comportamentais que a fez mudar de escolas várias vezes durante sua adolescência. Por volta dos vinte anos, após uma crise nervosa, a jovem Niki ficou internada num hospital psiquiátrico de Nice e foi submetida a terapia da pintura, o que a ajudou a lidar com sua crise. Foi neste período que decidiu se dedicar a pintura, abandonando então, o curso de arte dramática.

Nos anos de 1960, Niki ligou-se ao Novo Realismo (Nouveaux Réalistes, movimento de vanguarda francês que defendia a reciclagem poética do real urbano, industrial e publicitário) e realizou uma série de happenings onde, com uma espingarda, disparava tiros de tintas de diversas cores contra assemblages e figuras construídas em gesso e armação de arame. Essas sessões eram uma espécie de terapia, em que a artista deixava fluir todos os seus traumas, "Disparava sobre os homens, a sociedade e a sua injustiça, e sobre mim própria... Entregava-me por completo àquele macabro mas delicioso ritual." (Grosenick, 2005, p.292). As performances atraíram a atenção dos Novos Realistas, mas a originalidade da expressão de Niki de Saint-Phalle sobrepunha-se à negação das formas tradicionais reivindicadas por eles. Entre os Novos Realistas estavam os artistas americanos que viviam em Paris como Robert Rauschenberg, Jasper Johns, Larry Riversalistas e os franceses Pierre Réstany, Yves Klein, Christo, Martial Raysse, Arman, César, Daniel Spoerri. Entre eles, o artista suíço Jean Tinguely, com o qual Niki de Saint-Phalle começou a dividir a seu trabalho e sua vida nesta época.

Depois de dois anos nesta busca obstinada e catártica, em 1962, Niki entrou para um mundo mais intimista e feminino, começando a pintar noivas, grávidas prostitutas, "diferentes papéis que as mulheres podem assumir na sociedade" (Grosenick, 2005, p.292). Suas obras celebravam a felicidade e a liberdade do ser. Os monstros sanguinários deram lugar a dragões coloridos e inofensivos. Então Niki começou a iniciar suas primeiras experiências em papier-mâché e, gradativamente, incursionou nas formas tridimensionais e escultóricas.

A partir de 1965, dentro deste universo tridimensional, a artista desenvolveu "esculturas-bonecas", denominadas pela própria ar- 
tista de Nanas e Vênus. Essas obras oscilam constantemente entre a assemblage e a escultura, porque são feitas com estruturas de arame, papier-mâché, lã, tecido e muitas cores. Essas figuras se tornaram quase um símbolo da obra da artista e revelaram uma poética extremamente intimista e cheia de feminilidade, onde ela celebra a alegria com cores e formas exuberantes. $\mathrm{O}$ feminino é remetido através dessas figuras com seios, quadris, ventres protuberantes, demarcados por linhas pretas e cores fortes. A idéia de uma figura materna protetora e acolhedora é constantemente lida em suas obras. Não por acaso, é a característica que mais evidencia sua obra e, portanto, a que mais recebe atenção de teóricos e estudiosos. Trata-se de uma obra encantada, que representa criaturas fantásticas e maravilhosas: vegetais, animais, homens e, sobretudo, mulheres. Ela revisita mitos e lendas para unir a sombra à luz, o masculino ao feminino, o singular ao coletivo... Um mundo imaginário e universal, acessível a todas as gerações.

Sua poética feminina e acolhedora também pode ser vista em suas obras mais 'arquitetônicas', criadas em espaços públicos. "Interessante observar que a idéia de abrigo e de casa apareceu nas obras monumentais da artista, que, racionalizadas ou não, são construções que permitem a interação e a inserção do espectador dentro da obra." (Cabañas Pedro, 2008, p.34). As suas criações lúdicas integraram também os espaços públicos, com praças, fontes e jardins, que ganharam alma em diferentes cidades da Europa e dos Estados Unidos.

Em 1966, Niki, Jean Tinguely e Per Olof Ultvedt foram convidados pelo então diretor do Museu Moderna, em Estocolmo, a construir uma grande escultura localizada na entrada do museu. Tratava-se de uma Nana deitada e habitável de 26,7 metros de comprimento por 6,10 de altura. Essa obra foi nomeada de Hon ("ela" em sueco) e foi construída com estruturas metálicas, revestida com tecidos e fixada com cola, além de ser totalmente pintada aos moldes das obras de Niki. A entrada acontecia por um orifício situado entre suas pernas. Dentro de seu interior haviam dois andares com ambientes e cômodos, repletos de atrações lúdicas, como um bar, um planetário (aproveitando a forma arredondada 
dos seios), um cinema, um tobogã, projeções na parede, escultura radiofônica, uma videoteca, além de um mirante na parte de cima. Uma grande obra lúdica inserida dentro de um museu.

No mesmo ano desta última exposição, Saint Phalle e Tinguely participam junto com Martial Raysse, de concepção cenográfica e dos figurinos do espetáculo Lisístrata - peça escrita em 411 a.C. por Aristófanes. O texto tratava sobre a saga de uma ateniense, Lisístrata, que, cansada das guerras entre Atenas e Esparta, insufla as mulheres a fazerem uma bem sucedida "greve de sexo", obrigando seus maridos a pararem de lutar. "Os elementos cênicos utilizados pela artista bem como o estilo próprio de sua obra se encaixaram perfeitamente no contexto feminino da peça." A cenografia foi resolvida da seguinte maneira: foi criada uma Nana gigante que tomava toda a área do palco. Os atores penetravam e interagiam dentro desta Nana cenográfica "que simbolizava poeticamente o poder e a sexualidade feminina, sendo também a casa, o abrigo e a cidade que acolhe." (Cabañas Pedro, 2008, p.35).

Três anos depois, em 1969, Niki participou de uma exposição em Amsterdã, no Museu Stedelijk, chamada Les Nanas au Poivoir (Nanas no Poder). Nesta exposição foram mostradas as primeiras Nanas feitas em poliéster, material que ela usaria a partir de então em todas suas esculturas. Entre as obras expostas, foi apresentada uma grande escultura, com proporções monumentais, onde as pessoas podiam adentrar em seu interior. A obra chama-se Nana Casa: a idéia de penetrável consolidou-se em sua produção com esta gigantesca escultura. No acervo da Pinacoteca do Estado de São Paulo podemos constatar a graça e beleza de uma de suas Nanas. é a obra Fontes das Nanas, uma espécie de chafariz jocoso, onde os jatos de água saem das bocas, mamilos e mãos das quatro coloridas Nanas e desembocam no centro da fonte - a parte equivalente às suas virilhas.

Em meados de 1950, a artista em visita a Barcelona conheceu o famoso Park Güell do arquiteto espanhol Antoni Gaudí. Niki admitiu ter sido influenciada por essa arquitetura livre de rigidez, predominado formas as orgânicas, com total liberdade expressiva. A artista declarou certa vez: "Em 1955 estive em Barcelona. Lá vi 
o lindo Park Güell. Foi então que encontrei o meu mestre e o meu destino. Eu sabia que um dia teria meu próprio Jardim da Alegria. Um lugar entre o homem e a natureza." (Saint Phalle, apud Cabañas Pedro, 2008, p.63). Desde a concepção até o termino do Jardim de Tarô na região de Toscana, na Itália, passaram-se vinte anos. Em 1974 a artista ganhou um terreno de quase 1 hectare dos amigos italianos para a construção desse jardim lúdico. Em 1979 começaram as primeiras intervenções no jardim que só foi oficialmente inaugurado em maio de 1998. A artista enfrentou uma série de dificuldades, não só financeiras, mas também de saúde: ela foi acometida de uma dolorosa atrite que a impossibilitou por vezes de andar e mover as mãos. Porém ela manteve-se firme durante todos esses anos para terminar sua grandiosa obra. "Nada podia me parar, sentia que esse era meu destino, não importando o tamanho das dificuldades" (Cabañas Pedro, 2008, p.78). Uma equipe de dezenas de artistas e artesãos participaram da criação e construção deste grande e ousado projeto. No início dos anos de 1980, Niki acabou mudando-se para o jardim, morando durante sete anos dentro da peça Imperatriz para acompanhar de

perto o andamento das construções. Foram usados na estrutura das obras, concreto armado e, para o revestimento, cacos de vidro, de espelho e cerâmica. Cada uma das 22 esculturas criadas para o Jardim do Tarô foram inspiradas nas cartas do Tarô. ${ }^{12} \mathrm{~A}$ artista dedicou boa parte de sua vida, investimento, dores e alegrias neste jardim que foi, sem dúvida, sua maior obra.

12 A história mais antiga que se sabe sobre a origem do Tarô é que ela tenha surgido no Egito. Um sacerdote teria transmitido seus conhecimentos secretos, traduzindo-os em símbolos: os arcanos do Tarô. No total o Tarô possui 78 cartas, sendo estas divididas em duas partes: 22 Arcanos Maiores e 56 Arcanos Menores. No primeiro, os símbolos arquetípicos revelam os estados latentes das idéias e possibilidades da vida. No segundo, os resultados e as formas das idéias são expressos por quatro símbolos básicos: Naipe de Ouros, Naipe de Espadas, Naipe de Copas e Naipe de Paus. Cada naipe, por sua vez, possui dez arcanos numerados de AS a 10 e quatro arcanos com figuras da corte medieval: Valete, Cavaleiro, Dama e Rei (Cabañas Pedro, 2008, p.81). 


\title{
Judy Chicago (Estados Unidos, 1939)
}

\author{
A sua monumental obra \\ A festa de jantar (1974-1979) é uma homenagem \\ às realizações femininas na política, na arte $e$ \\ na religião. A festa de jantar levantou questões \\ acaloradamente debatidas entre as feministas.
}

Georges Duby e Michelle Perrot

A artista norte-americana Judy Chicago tem em sua obra uma vertente fortemente feminina e, muitas vezes, tendendo para o feminismo. Judy era anteriormente conhecida por Judy Gerwitz, o sobrenome adquirido no casamento. Após sua separação, a artista decidiu retirar o nome do ex-marido e trocou-o pelo nome de sua cidade natal, Chicago. Essa atitude, em plena época das mudanças sexistas, demonstrava o quão era significativo para uma mulher não ser reconhecida pelo nome de quem fora casada, mas sim por seu próprio nome, por suas origens e raízes. Judy criou uma carreira embasada em suas determinações feministas, tanto nas artes, como na docência, colocando em cheque muitas das tradições e da herança cultural da mulher.

Sua obra de maior envergadura foi, sem dúvida, The dinner party (A festa de jantar, 1974-79). Essa instalação de proporções grandiosas contou com a ajuda e colaboração de uma equipe de variadas pessoas (na sua maioria mulheres) ${ }^{13}$ durante mais de cinco anos de

13 Membros da equipe: Daphne Ahlenius, Marilyn Akers, Pat Akers, Katie Amend, Marilyn Anderson, Ruth Askey, Cynthia Betty, Marjorie Biggs, Judy Blankman, Terry Blecher, Sharon Bonnell, Susan Brenner, Thelma Brenner, Julie Brown, Frances Budden, Peter Bunzick, Susan Chaires, Pamela Checkie, Aldeth Spence Christy, Marguerite Clair, May Cohen (mãe de Judy Chicago), Audrey Cowan, Joyce Cowan, Ruth Crane, Laura Dahlkamp, Lynn Dale, holly Davis, Michelle Davis, Sandi Dawson, Ellen Dinerman, Jan Marie DuBois, Elizabeth Eakins, Laura Elkins, Marny Elliot, Kathy Erteman, Faye Evans, Peter Fieweger, Marianne Fowler, Cherié Frainé, Libby Frost, JoAnn Garcia, Diane Gelon, Ken Gilliam, Dorothy Goodwill, Winifred Grant, Estelle Greenblatt, Amanda haas, Jan hanson, Judy hartle, Arla hesterman, 
execução. No livro escrito pela própria artista The dinner party: a symbol of our heritage ela relatou a experiência de realizar este trabalho em equipe: "O grupo gradualmente se tornou em estruturas grupais autossuficientes que trabalhavam sob minha orientação, enquanto construíam também trabalhos em equipe, dividindo as responsabilidades e o diálogo honesto" (Chicago, 1979, p.7). Judy também contou sobre como surgiu a inspiração para fazer esta obra: durante uma viagem na costa noroeste no verão de 1971, ela viu em um antiquário pratos pintados à mão e se interessou pelo seu processo de confecção. No ano seguinte, ela ingressou em um curso de técnicas de pintura chinesa em porcelana para aprender mais sobre esse universo. Posteriormente, Chicago teve aulas com uma grande artista especializada em na técnica de pintura chinesa, Mim, onde seu interesse por desenvolver o trabalho de com cerâmica aumentou ainda mais.

No início, a artista pensou em fazer uma instalação com cem retratos abstratos em pratos de cerâmica pintados à mão e pendurados na parede, homenageando diferentes figuras femininas. Posteriormente veio a idéia de colocar os pratos em uma mesa de jantar,

Robin hill, Susan hill, Shannon hogan, Meredith Dalglish-horton, A. Springer hunt, Elaine Ireland, Ann Isolde, Anita Johnson, Lyn Jones, Nancy Jones, Sharon Kagan, Bonnie Keller, Cathryn Keller, David Kessenich, Judye Keyes, Mary helen Krehbiel, Sherri Lederman, Julie Leigh, Ruth Leverton, Virginia Levie, Thea Litsios, C. Alec MacLean, Shelly Mark, Mary Markovski, Stephanie G. Martin, Sandra Marvel, Judith Mathieson, Laure McKinnon, Marie McMahon, Mary McNally, Susan McTigue, Amy Meadow, Chelsea Miller, Kathy Miller, Judy Mulford, Juliet Myers, Natalie Neith, Laura Nelson, L. A. Olsen, Logan Palmer, Anne Marie Pois, Dorothy Polin (sobrinha de Judy Chicago), Lynda Prater, Linda Preuss, Betsy Quayle, Rosemarie Radmaker, Charlotte Ranke, Rudi Richardson, Martie Rotchford, Roberta Rothman, Bergin Ruse, Karen Schmidt, Kathleen Schneider, Mary Lee Schoenbrun, Pauline Schwartz, Elfi Schwitkis, Manya Shapiro, Linda Shelp, Dee Shkolnick, helene Simich, Louise Simpson, Leonard Skuro, Elsa Karen Spangenberg, Sarah Starr, Millie Stein, Catherine Stifter, Leslie Stone, Gent Sturgeon, Beth Thielen, Margaret Thomas, Sally Torrance, Kacy Treadway, Sally Turner, Karen Valentine, Betty Van Atta, Constance von Briesen, Audrey Wallace, Adrienne Weiss, Judith Wilson. 
como um meio de representação simbólica da exclusão de muitas mulheres na história. ${ }^{14}$ Chicago pensou em uma releitura da Última Santa Ceia sobre o ponto de vista da mulher que, através da historia, teria apenas se prestado a "preparar as refeições e colocar a mesa". Assim, da mesma forma que na Santa Ceia haviam treze homens, a artista pensou em selecionar treze grandes mulheres, porém logo percebeu que esse número era insuficiente e que desta forma, poderia cometer certas injustiças. O problema foi resolvido com o uso da mesa triangular: os treze pratos em porcelana foram multiplicados pelos três lados da mesa, tornando-se trinta e nove. Toda a parte do piso que sustentava a mesa foi composto por triângulos de porcelana esmaltada e em cada um deles, haviam nomes de quase mil mulheres (exatamente novecentas e noventa e nove) que também tiveram relevância histórica - fosse mitológica, religiosa, artística, literária, musical, teatral etc. Todos os pratos, talheres e copos foram feitos em porcelana esmaltada. As toalhas de mesa (que no Brasil chamamos de jogo americano), que compunham o jogo de pratos, talheres e copos, foram criadas, tecidas e bordadas por membros de sua equipe.

Em cada uma das laterais da mesa (as arestas do triângulo) foram feitas divisões cronológicas para facilitar a leitura da obra. De um dos lados, podemos verificar a divisão que vai da pré-história ao Império Romano, em seguida, temos mulheres que vão desde o início do Cristianismo à Reforma e, finalmente, mulheres da América à Revolução Feminista. No site do The Brooklin Museum ${ }^{15}$ encontramos os respectivos nomes e origens de cada mulher homenageada. Podemos notar o cuidado da artista em representar artística e simbolicamente essas mulheres, na medida em que cada jogo de pratos, talheres, copos e toalhas, foi minuciosamente construído e criado a partir de uma vasta pesquisa desenvolvida por ela e sua equipe.

14 É como se, pelo fato de a artista estar representada em um prato de jantar, simbolicamente ela pudesse ser ingerida e, de certa forma, desaparecer visualmente.

15 http://www.www.brooklynmuseum.org/ 
Mesa I: Da pré-história ao Império Romano

1. Deusa Primordial

2. Deusa da Fertilidade

3. Ishtar (Deusa Suméria da fertilidade e da primavera)

4. Kali (Deusa hindu da energia vital)

5. Deusa Serpente (Deusa aminóica - 1600 a.C.)

6. Sophia (Deusa grega da sabedoria 323-147a.C.)

7. Amazonas (Mitologia das mulheres guerreiras da Grécia Antiga)

8. Hatshepsut (Faraó egípcia - 1479 a 1458 a.C.)

9. Judite (Deuterônimos - Velho testamento)

10. Safo (Grécia entre 630 e 612-570 a.C.)

11. Aspasia (Grécia 400 - 470 a.C.)

12. Boudica (Rainha Celta - século V)

13. Hipátia de Alexandria (Grécia 370-415)

Mesa II: Do início do Cristianismo à Reforma

14. Santa Marcella (Roma antiga 325-410)

15. Santa Brigite (Suécia 1303-1373)

16. Teodora da Bizantina (Grécia 500-548)

17. Hrosvitha (Alemanha 935-1002)

18. Trotula de Salerno (Salerno século XI-XII)

19. Eleonor da Aquitaine (Aquitaine 1122-1204)

20. Hildegard de Bingen (Alemanha 1098-1179)

21. Petronilla de Meath (c. 1300-1324)

22. Christine de Pisan (Pisan 1363-1434)

23. Isabella d'Este (Itália 1474-1539)

24. Elizabeth I da Inglaterra (Inglaterra 1533-1603)

25. Artemisia Gentileschi(Itália 1593-1653)

26. Anna van Schurman (Alemanha 1607-1678)

Mesa III: Da América à Revolução Feminista

27. Anne Hutchinson (Inglaterra 1591-1643)

28. Sacajawea (Dakota 1788-1812)

29. Caroline Herschel (Alemanha 1750-1848) 
30. Mary Wollstonecraft (Inglaterra 1759-1797)

31. Sojourner Truth (Nova York 1797-1883)

32. Susan B. Anthony (Massachusetts 1820-1906)

33. Elizabeth Blackwell (Inglaterra 1821-1910)

34. Emily Dickinson (Massachusetts 1830-1886)

35. Ethel Smyth (Inglaterra 1858-1944)

36. Margaret Sanger (Ohio 1876-1972)

37. Natalie Barney (Nova York 1879-1966)

38. Virginia Woolf (Inglaterra 1882-1941)

39. Georgia O'Keeffe (EUA 1887-1986)

Entre as 999 mulheres homenageadas no piso da instalação, estão Teresa de Ávila, Rosa de Luxemburgo, Margaret Mead, Maria Montessori, Wanda Landowska, Käthe Kollwitz, Suzane Langer, Sophie Teuber-Arp, Sonia Delaunnay, Simone de Beauvoir etc.

Segundo Toulze ${ }^{16}$ podemos entender que se por um lado a artista quis deflagrar o papel doméstico designado às mulheres, no modo especial de uma mesa bem posta, com louças impecáveis, jogos de mesa bordados e tantos outros códigos deste universo doméstico feminino, por outro lado, ela prestou uma impactante homenagem às mulheres de modo engajado. Não foi ingênua a escolha de Judy ao usar materiais como a cerâmica, o bordado e a tapeçaria para representar essas mulheres. Atividades como estas foram durante muito tempo consideradas "artes menores" e eram realizadas especialmente por mulheres. Sobre The dinner party, Judy Chicago, certa vez declarou: "Essas convidadas, mulheres reais ou deusas, estão colocadas juntas para cear e discutir, conversar. E, que nós escutemos o que elas têm a dizer, contemplemos a amplitude e beleza de nossa herança. herança essa, que não temos tido oportunidade de conhecer" (Porqueres apud Senna, 2007, p.38).

The dinner party sofreu muitas críticas ferrenhas com relação ao seu conteúdo declaradamente feminista. Mas foi justamente por essa razão, que Judy conseguiu estabelecer-se no meio artístico e,

16 Cf. Toulze. Disponível em: http://www.unb.br/ih/his/gefem/labrys3/ web/bras/marielle1.htm. Acesso 24/04/09 às 12h. 
inclusive, desenvolver uma carreira como professora engajada. A artista/professora foi uma das pioneiras na criação de um curso feminista na State College de Fresno e na School of Art de Los Angeles, criou um programa feminista com a colaboração de Miriam Schapiro em 1971. Era estimulado pelas artistas uma postura de valorização e de novas formas de experimentação do corpo da mulher através das próprias mulheres, diferentemente do modo como as tradicionais formas de manifestações artísticas mostravam. Em 1999, Judy em parceria com o historiador Edward Lucie-Smith, publicou o livro Women and art: contested territory. Neste livro, ambos selecionaram e analisaram obras das artistas em toda história da arte. Nessas imagens, que vão desde a Antiguidade até o século XX, eles desvendam as múltiplas representações dos arquétipos femininos recorrentes na civilização ocidental (Senna, 2007, p.38).

Com essa grandiosa obra, Judy tinha como meta maior ir contra o descaso e a supressão de inúmeras artistas pela história da arte. Esse objetivo foi em grande parte cumprido, na medida em que a obra foi mostrada em uma série de locais, desde sua primeira exposição em São Francisco em 1979 no Museu de Arte Moderna. Atualmente, a obra faz parte do acervo permanente Elizabeth A. Sackler Center for Feminist Art e está permanentemente instalada no The Brooklin Museum, em Nova York (EUA), para ser devidamente apreciada e analisada por todos que queiram contemplá-la in loco.

\section{Ana Mendieta (Cuba, 1948-1985)}

Ana Mendieta explorou o corpo feminino através de sua concretude física, suas mutações cíclicas, seus fluídos e seus sentidos, na busca de uma identidade perdida.

Nádia da Cruz Senna

A obra Primeira mulher (1981), gravada em uma caverna cubana, estabelece um vínculo inequívoco com as imagens da Deusa, 
cultuada pelos povos primitivos. A legitima apropriação de um imaginário que afirma o poder feminino e enaltece o sexo como fonte criativa, responde ao desejo da artista de religar o corpo com a energia dos elementos e refazer as relações com a natureza. Também corresponde a uma representação que rompe com os esquemas tradicionais reservados à figuração das mulheres. Ana Mendieta explorou o corpo feminino através de sua concretude física, suas mutações cíclicas, seus fluidos e seus sentidos, na busca de uma identidade perdida.

Uma das mais importantes representantes da performance nos anos de 1970 foi a artista cubana Ana Mendieta. Seu trabalho artístico compreende tanto os registros fotográficos e filmográficos de suas performances, quanto esculturas e pinturas.

A artista cubana aos doze anos, juntamente com sua irmã mais velha, fugiram para os Estados Unidos em 1961 devido à revolução cubana de 1959. Na juventude Mendieta estudou na Universidade de Iowa, nos anos de 1970, época em que as vanguardas artísticas e o movimento feminista estavam proliferando fortemente. Foi neste período que Mendieta começou a fazer suas performances e os chamados "earth-body works". ${ }^{17}$ Contudo, apesar da sua formação ter sido norte-americana, a artista tinha uma autonomia representativa voltando-se sempre para suas raízes latino-americanas.

Entre 1973 a 1980 ela desenvolveu uma série intitulada Siluetas. Esta série foi o seu trabalho mais comentado e consistia basicamente em imprimir seu próprio corpo na paisagem. A artista realizou mais de uma centena de obras feitas normalmente no chão, sob diversos tipos de terrenos: gramas, areia, solo rochoso, terra batida ou molhada, vegetação rasteira, plantas, flores, água, água do mar. Em algumas delas, Mendieta preenchia com pigmentos vermelhos, ou atava fogo, demarcando os limites do corpo com pólvora e incendiava.

17 Earth-body works eram intervenções esculturais em que a artista inseria a forma (silhueta) de seu próprio corpo na paisagem, fosse na forma oca, ou seja, retirando a terra, fosse acrescentado elementos à ela. 
Morte e vida, em seus aspectos naturais e culturais, são temas recorrentes. Alguns de seus earth-body works e de suas performances foram gravados e fotografados. Quer seja reproduzindo com seu corpo uma cena de estupro ou inscrevendo símbolos femininos na paisagem, seus trabalhos marcaram a história da arte recente. ${ }^{18}$

Em Siluetas, Mendieta sintetizou uma tendência em voga nos anos de 1970, uma "estrutura primária" através do simples contorno de seu corpo, destacado na fluidez da intervenção da paisagem natural - que ora é consumido pelo tempo, ora é derretido pelo calor do sol, ora desfeito pelo movimento do vento ou desmanchado pela força da água. "Desenhada com flores na superfície de um lago e marcada na praia, ela vai se dissolvendo lentamente, pela ação das ondas, e se desintegra quando fica presa a uns precários suportes de fogos de artifício". ${ }^{19}$ Dessa maneira, suas representações, foram tais como ela desejava, engolidas pela força da natureza, ou como alguns talvez prefiram, pelo processo natural da vida.

Não podemos deixar de lembrar o quanto foi marcante para sua vida pessoal e, consequentemente, na sua produção artística, a saída brusca de seu país natal e o fato de se ver impossibilitada de retornar por um longo período às suas raízes. "Sinto-me tomada pela sensação de ter sido arrancada do útero (a natureza). A arte é a forma pela qual restabeleço minhas ligações com o universo. É um retorno à origem maternal" ${ }^{20}$ A artista afirmou que talvez fosse por esta razão que ela buscava incessantemente se representar como parte da terra, como uma forma desenhada pela lama, pelos buracos, nas paredes de pedras, folhas, plantas, vegetação, flores, águas

18 Cf. Rivitti. Disponível em: http://diversao.uol.com.br/27bienal/artistas/ ana_mendieta.jhtm. Acesso em: 13/08/08 às 16h20.

19 Cf. Saccá. Disponível em: http://www.memorial.sp.gov.br/revistaNossaAmerica/23/port/26-Corpo_como_experiencia.htm. Acesso em 11/06/09 às 16h30.

20 Cf. Barreras Del Rio apud Brett. Disponível em: http://www2.sescsp.org.br/ sesc/videobrasil/up/arquivos/200607/20060710_124405_Ens_AMendieta_GB rett_CVB_P.pdf. Acesso em: 11/06/09 às 9h. 
(vales, riachos, mar), pigmentos, fogo, destroços trazidos pelo mar, terra pantanosa, a grama, a neve. A forma apresentada através do processo de deformação natural. A necessidade em se fundir na terra, em sua terra mãe é claramente exposta nesse habitat acolhedor esculpido na natureza. "Além disso, produção e dissolução estão unidas no mesmo processo; não existe um momento de finalização da obra. A arte de Mendieta alcança tamanho grau de condensação, que todos esses elementos ficam intensamente gravados na mente [...]" (Brett, 2004). Em sua produção artística, o corpo é o instrumento ideal e real na busca da reconquista de sua identidade:

Desde 1970 minha manifestação artística consiste num diálogo com o natural. É o meio que achei de tornar concretas as minhas raízes emocionais com a minha terra e também de conceitualizar minha cultura. Quando meus pais me enviaram para fora de Cuba em 1961, eu me senti arrancada do seio da minha pátria. Minha arte celebra a interconexão do mundo humano e material no plano da corporeidade, o renascer de anseios antiqüíssimos como a promessa de um futuro melhor. A obra efetuada nas Escaleras de Jaruco ${ }^{21}$ tem sido de um grande valor para mim, porque foi minha primeira oportunidade de trabalhar em solo cubano... Usando raízes... me foi possível trabalhar cinco corações, que representam as cinco subdivisões das culturas indígenas cubanas. Estes cinco corações devem ser colocados sobre a terra vermelha, uma terra que soube absorver tanto sangue derramado antes de chegar à terra de liberdade que é hoje. (Saccá, 2006)

O sangue, tão familiar na vida da mulher, é também um dos elementos recorrentes em suas experiências performáticas. As formas femininas na terra, com a terra e através da terra. Apesar de Mendieta não ter tido uma formação em cerâmica, ela estava profundamente ligada a essência do barro, ao usar a terra de modo lite-

21 Local onde a artista escavou as Esculturas rupestres (1981) e refúgio de rebeldes na época da guerra de independência de Cuba. 
ral ou metafórico. Podemos verificar também a forte ligação com a Mãe Terra, Pachamama, na medida em que muitas crenças e mitos contam que os seres humanos são originários do barro. ${ }^{22}$ Ao ser indagada sobre por que utilizava imagens que representam morte ou enterro de forma consciente, a artista respondeu: "Não acho que possamos separar a morte e a vida. O meu trabalho gira em torno de duas coisas... é sobre Eros e sobre morte/vida" (Eshleman apud Brett, 2004, p.67).

Sua morte trágica e muito precoce é ainda uma grande incógnita, ${ }^{23}$ visto que a jovem artista estava numa fase de grande produtividade e já havia manifestado o intuito de morar na Itália (após ter recebido uma bolsa de estudos na Guggenheim e o Prêmio da Academia Americana de Roma). O New Museum de Nova York, realizou uma exposição póstuma em 1987. "Arte simples, a sua, a ponto de ser considerada como um autorretrato íntimo, segundo uma afirmação dela que retoma obsessivamente a figura da própria Silhueta." A obra de Mendieta foi um modo lírico e poético de se contactar com sua terra natal; com algo que fosse além da criação artística e atingisse uma linguagem universal. Foi um grito silencioso e solitário projetado sob a forma da sua própria figura na terra. Foi uma constante procura da identidade, de "uma espécie de caminho interior, que deveria recompensá-la pela sua adolescência negada, pela sua vida interrompida pela lama impiedosa da história. Seu gesto é vivido na solidão, uma característica que sempre a acompanhou." (Saccá, 2006)

Uma obra feminina que foi testemunhada e digerida pela e para a Pachamama.

22 Para esse tema, ver o capitulo 1.

23 Ana caiu do $34^{\circ}$ andar de seu prédio. O marido de Mendieta, o escultor minimalista Carl André, apesar de ter sido o principal suspeito de sua morte, foi absolvido com a alegação de defesa de um possível suicídio ou mesmo de um acidente. 


\section{4 \\ A MULHER: FORMA OU FÔRMA? \\ RECIPIENTES DO VIR-A-SER: DEPOIMENTO DE ARTISTA}

"A imagem poética transporta-nos a origem ser falante."

Gaston Bachelard, A poética do espaço

Este livro tem como um dos propósitos mostrar a significação do meu fazer artístico no campo de produção em relação a algumas artistas. Assim, como a obra das artistas apresentadas neste livro, minha obra também procura evidenciar, de algum modo, o complexo modo de ser feminino, perante a problemática da atualidade. Procuramos, eu e essas artistas, através da linguagem visual, abordar questões relativas às buscas individuais de identidade, associadas ao que seria um discurso visual do feminino no ocidente.

A cerâmica foi o suporte eleito para que a força do feminino se mostrasse em minha produção. Através deste material plástico e moldável, pude entrar em contato, de forma mais intuitiva, com meu universo interior, refletindo-me como mulher, pesquisadora e artista. Nesta busca de mim mesma através da argila fui até milhares de anos atrás, (re)encontrei-me com nossas ancestrais, as mulheres que eram cultuadas como deusas, como criadoras e fertilizadoras, mulheres ventre, mulheres pote, as Mulheres recipientes. Depois, deparei-me com novos (re)encontros de outras tantas mulheres precursoras que haviam aberto o caminho, para que eu e 
outras mais, pudéssemos trilhá-lo sem tantas dificuldades. Finalmente, (re)encontrei as sementes responsáveis pelo fruto da minha produção artística, as seis artistas (es)colhidas: as germinadoras. Assim como essas artistas, tenho buscado na força das deusas da fertilidade e nas diversas simbologias do universo feminino expressar-me artisticamente. Por esta razão, elas foram (es)colhidas para serem o fio condutor responsável pela formação de toda a tessitura poética que perpassa por minhas obras, através de uma livre associação entre nossos fazeres artísticos, inserindo-a no atual discurso da arte contemporânea.

Perceber de que modo a minha produção em cerâmica se inseriu em um contexto artístico e simbólico, não foi uma tarefa simples, pois exigiu um grande esforço de observação e certo distanciamento. Foi somente depois de todo o processo de levantamento de dados para a pesquisa e da leitura analítica das poéticas das artistas germinadoras e da minha própria poética, é que pude perceber que minhas esculturas estavam, de alguma forma, reverenciando e referenciando o feminino nas artes visuais. Talvez se faça importante dizer que as minhas principais indagações estão mais ligadas ao cerne da questão sobre como o feminino, que está presente nas artistas criadoras, é manifestado em suas obras e não apenas o que poderíamos nomear simplesmente de uma 'arte feminina'. Conceitualmente, o que ocorre em Mulheres recipientes, é uma idéia do feminino, manifestado em formas que insinuam o corpo da mulher, as partes femininas: seios, nádegas, vaginas, ventres. Todavia, esses ventres não se encontram cheios de uma possível vida, são vazios, ocos, estão à espera de serem preenchidos. Esse é o papel do vazio no simbólico, evocar os conteúdos que o vazio contém. Como a taça se enche e dá de beber.

\section{E ao barro voltarás}

"Nada mais natural que a escolha da pasta de barro para a fala feminina do fazer plástico: ela é macia, flexível, ondulante."

Lélia Coelho Frota 
A cerâmica foi e ainda é um dos suportes plásticos mais utilizados no meio artístico tridimensional: seja como um meio para se chegar a um fim (protótipo), seja como um fim em si mesmo (escultura). Historicamente, não há como negar a importância deste material para as artes plásticas, o design e o artesanato.

Ao trabalharmos a argila, entramos em contato, direta e indiretamente, com os quatro elementos da natureza: a terra (massa plástica formada de barro), a água (massa plástica, também, composta por líquido), o ar (oxigênio é fundamental para queima das peças), e o fogo (o calor produzido pelas queimas à lenha, gás e elétrica). Existe, concomitantemente, um outro fator que é condição sine qua non para todos os processos da cerâmica, o tempo, pois cada estágio demanda um preparo específico e um período especial de maturação.

Há de se constatar que a maioria das pessoas que já tiveram algum contato com a argila, é capaz de perceber o quanto ficamos imersos na ação de modelar o barro. Muitas vezes, acabamos por nos envolver de tal modo, que os quatro elementos nos transportam para um mundo de sensações novas, quase mágicas e misteriosas. A argila é capaz de nos fazer voltar "para dentro" de nós mesmos, pois é necessário considerável concentração e certo desprendimento daquilo que é externo, para direcionarmos a energia naquela massa plástica. No momento de sovar e modelar o barro, temos a sensação de que nos religamos com algo perdido há muito tempo. Nos últimos dois séculos, nossa relação com a natureza tornou-se cada vez mais restrita, e o contato direto que tínhamos com os quatro elementos intrínsecos à argila ocorre, na maioria das vezes, de modo industrializado: a água nos chega através dos encanamentos, o fogo através do gás no fogão, a terra encontra-se apenas em vasos de plantas ou em pequenos jardins e o ar em ambientes fechados é condicionado e está cada dia mais impuro e poluído.

Assim, quando nos concentramos em realizar ações ligadas ao nosso poder criativo, ao nosso lado direito do cérebro, somos capazes de deixar fluir elementos e imagens que há muito tempo estavam armazenadas em nosso inconsciente, ou seja, tudo o que faz parte de nosso vocabulário imagético, os chamados arquétipos. 
Para aprofundar um pouco mais a definição de arquétipos, recorro ao criador deste conceito: Carl G. Jung. Segundo ele, os arquétipos seriam símbolos ${ }^{1}$ que representam sentimentos inconscientes e universais, ou seja, habitam a memória de todas as pessoas. $\mathrm{O}$ inconsciente coletivo é fundamentalmente composto pelos arquétipos que se manifestam exteriormente, através de sonhos ou das manifestações artísticas (os desenhos, por exemplo). Jung afirma também que muitos aspectos do nosso inconsciente influenciam na nossa percepção da realidade. Todos os fenômenos perceptíveis são transpostos através dos nossos órgãos sensíveis para nossa mente. A nossa mente traduz esses fenômenos para acontecimentos psíquicos, cuja natureza extrema ainda nos é desconhecida: não somos capazes de entender claramente como alguns processos psíquicos ocorrem. Ou seja, todos os acontecimentos que se tornaram uma experiência possuem um número indefinido de fatos desconhecidos para nossa mente e, consequentemente, para nosso entendimento consciente (Jung, 1977, p.20 a 23)

Muito provavelmente foi assim que ocorreu comigo quando comecei a trabalhar com a argila. Minhas primeiras peças já remetiam indubitavelmente a todos esses assuntos sobre as mulheres, mitos de deusas, ritos de fertilidade, sem eu mesma ter tido um pensamento consciente. As peças que produzi eram de pequenas dimensões, quase do mesmo tamanho das vênus - que tinham o tamanho ideal para caberem entre as mãos, sendo de fácil acesso ao toque e aos cultos de fecundidade, de adoração à Grande Mãe Terra - e remetiam a um corpo feminino em forma de banheira. Eram peças cerâmicas que revelavam uma expressão de imagens arquetípicas do universo feminino, tanto em seu conteúdo formal, como conceitual.

As formas femininas pareciam brotar da argila, cada vez que eu começava uma nova peça. Obviamente, muitas formas eram inten-

1 Jung define os símbolos como "um termo, nome ou mesmo uma imagem que nos pode ser familiar na vida diária, embora possua conotações especiais além de seu significado evidente e convencional. (...). Esta palavra ou esta imagem têm um aspecto 'inconsciente' mais amplo, que nunca é precisamente definido ou de todo explicado" (Jung, 1977, p. 20). 
cionais, planejadas e estruturalmente pensadas. Inclusive, este é um dos modos que aprendemos ao lidar com a argila, pois, por mais maleável e plástica que ela seja, é um material que tem características marcantes de funcionamento: nós é que devemos aprender e respeitar seu ritmo e não impor nosso.

E assim, como as coisas precisam de um tempo para se formar, crescer e desenvolver-se, "tudo tem o seu tempo determinado, e todo o propósito debaixo do céu tem o seu tempo - há tempo de nascer e tempo de morrer: tempo de plantar, e tempo d'arrancar o que se plantou." (Bíblia, Eclesiastes 3.1,2). Assim também é com a argila: existe o tempo certo de colher, de preparar, sovar, modelar, secar e queimar o barro. Se a massa não está "no ponto", ou seja, se ela está muito molhada ou muito seca (a temperatura do ambiente também influencia nisso), não conseguimos trabalhar devidamente. E, depois de modelarmos a peça, mesmo que ela seja muito simples ou feita rapidamente, a peça só pode ser ocada ${ }^{2}$ após alguns dias, caso contrário, podemos deformá-la e estragar todo o trabalho anterior. A peça deve estar no que chamamos de "ponto de couro" - é o momento em que ela já está firme o bastante para não deformar ao toque mais forte, porém ainda está úmida o suficiente para que se consiga retirar o excesso: todas as partes (ou "paredes" como normalmente chamamos) devem ter a mesma espessura, pois é isso que fará a peça secar uniformemente e evitará rachaduras ou mesmo que ela se quebre. Um outro motivo para ocar a peça, como já foi citado, é para eliminar as bolhas de ar na massa plástica que podem ocasionar quebras durante a queima. O ponto de couro também é o momento ideal para fazer alguma intervenção na peça, como por exemplo: uma pintura com engobe, que é a própria argila pigmentada. Quando a peça está um pouco mais seca que o ponto de couro é também o momento ideal para fazer grafismos e pequenas incrustações ou furos. Só depois de a peça estar inteiramente pronta para a queima é que devemos deixá-la secar totalmente, deixá-la no que chamamos "ponto de osso". Porém,

2 Ao ocar uma peça, retiramos toda sua parte interna, tomando o cuidado de manter sempre a mesma espessura das paredes. 
ainda assim, essa secagem deve obrigatoriamente acontecer de modo gradual, pois caso ela comece a secar mais rápido nas pontas que na parte central, fatalmente as rachaduras e trincas aparecem. Muitas vezes são imperceptíveis antes da queima, mas podem aumentar consideravelmente depois de prontas, ou seja, durante a queima.

No início da produção da série Mulheres recipientes, minhas peças eram feitas através de modelagem única, ou seja, eram criadas a partir de uma idéia ou desenho inicial e ao poucos iam sendo moldadas, acrescentando ou retirando partes da argila. Muitas vezes era preciso colocar estacas de madeira para sustentar a peça, como mostra as fotos em que trabalho (Figura 1 e 2). Essas estacas são retiradas assim que a peça já esteja seca o bastante para se sustentar sem esses apoios. A peça não pode secar e nem tão pouco ser queimada com as estacas; pois isso pode causar sérios danos, como rachaduras e até mesmo a destruição da peça durante a queima.

No princípio, a série era mais figurativa, mostrava uma preocupação com a proximidade das formas do corpo feminino: pernas, braços, rostos com feições, além dos seios, vaginas e quadris (Figura 3). Porém, essas peças já mostravam a parte referente ao ventre como vazia, oca, um ventre apto a receber, como um recipiente, como são na essência as Mulheres recipientes. Meu processo criativo encaminhou-me para contínuas alterações no feitio das peças. Depois de desenvolver uma série de esculturas modelando uma a uma, comecei a utilizar moldes de gesso em formato de meia esfera e assim pude evidenciar ainda mais a idéia do ventre oco, do espaço a ser preenchido em potencial. Essa intenção, esse fio condutor foi trilhado desde o início, até as peças mais recentes.

Existem várias maneiras de se colocar a argila dentro dos moldes de gesso. O processo utilizado por mim foi através de placas: com um fio de nylon, corto o bloco de argila com uma espessura de aproximadamente dois centímetros. Depois coloco essas placas entre dois tecidos e a pressiono com um rolo ou uma prensa (Figura 4). A espessura da placa diminui, ao mesmo tempo em que aumenta a sua dimensão em área. Já com a placa na dimensão desejada, assento-a dentro do molde redondo (Figuras 5 e 6 ). 

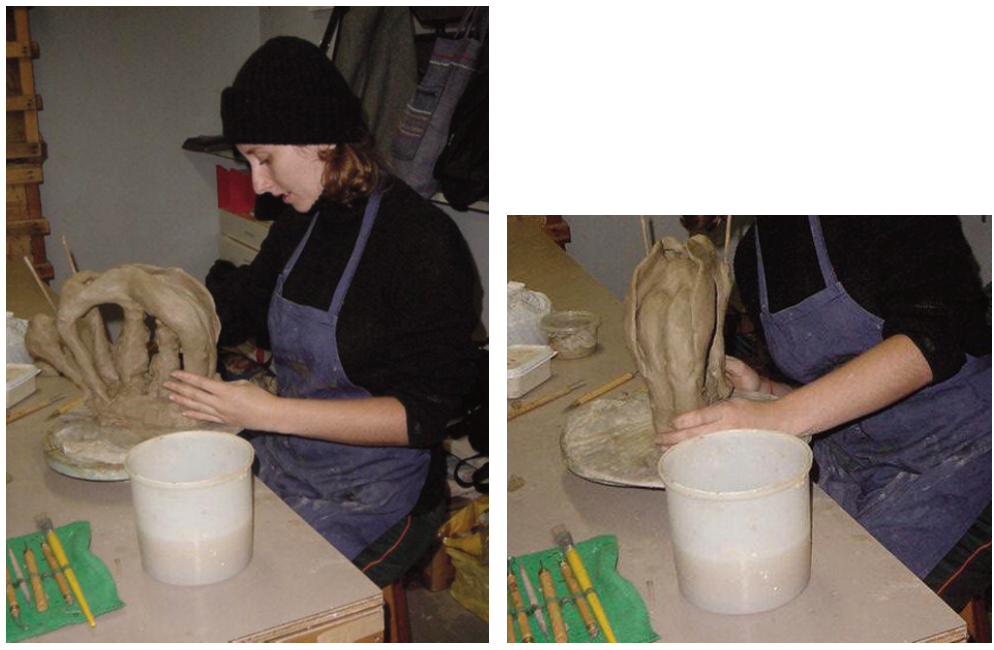

Figuras 1 e 2 - Modelagem de peça em argila por Flávia Leme. Atelier de Cerâmica do Instituto de Artes da Unesp, 2002. Foto: Vera Cozani.

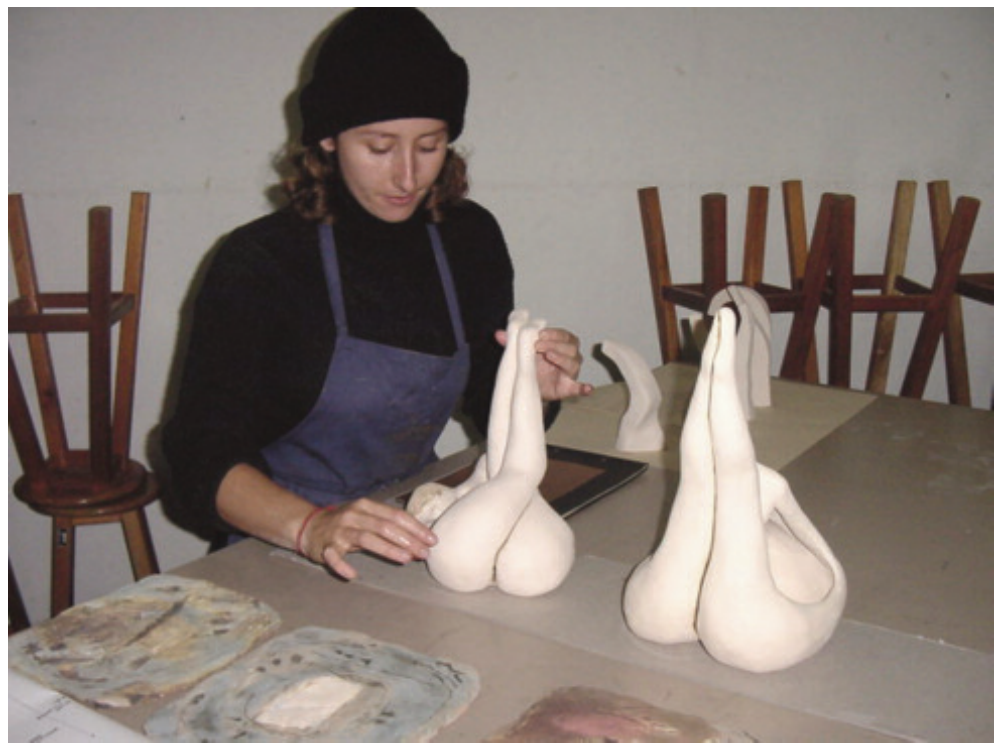

Figura 3 - Peças em argila branca por Flávia Leme. Atelier de Cerâmica do Instituto de Artes da Unesp, 2002. Foto: Vera Cozani. 


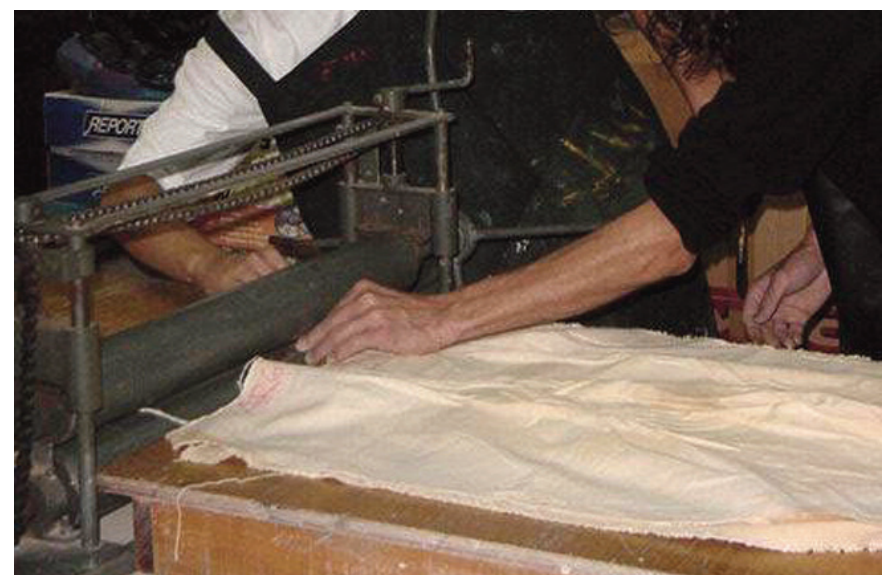

Figura 4 - Prensa para fazer placas de argila. Atelier de Cerâmica do Instituto de Artes da Unesp, 2003. Foto: Flávia Leme.
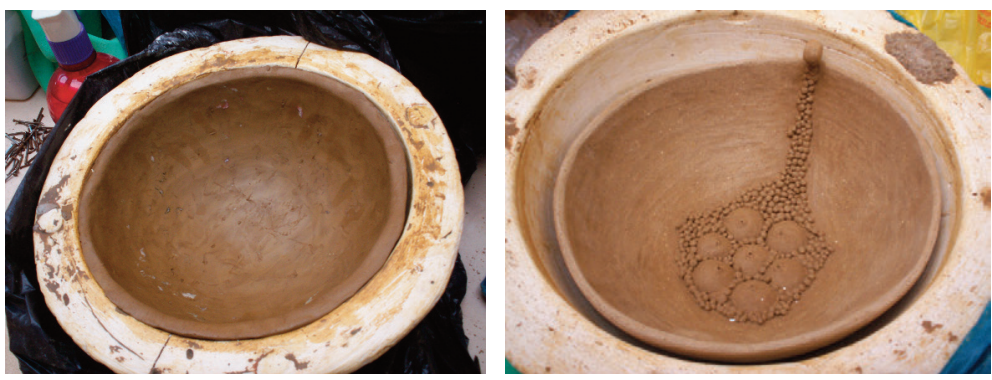

Figuras 5 e 6 - Placas de argila assentadas nos moldes de gesso (a figura superior ainda com argila úmida e a figura de baixo já em ponto de couro). Atelier de Cerâmica do Instituto de Artes da Unesp, 2007 e 2008. Foto: Flávia Leme.

Para desenvolver peças em um formato maior, tive que desenvolver um molde, pois os disponíveis no atelier do Instituto de Artes da UNESP não estavam no tamanho que gostaria para aquele momento. Consegui uma semiesfera de acrílico de $82 \mathrm{~cm}$ de raio e $30 \mathrm{~cm}$ de profundidade e, através dela, fiz um novo molde de gesso. Foi um processo demorado e que exigiu a colaboração de duas pessoas: Vera, técnica do atelier e Rose, funcionária terceirizada (Figuras 7, 8, 9 e 10). 

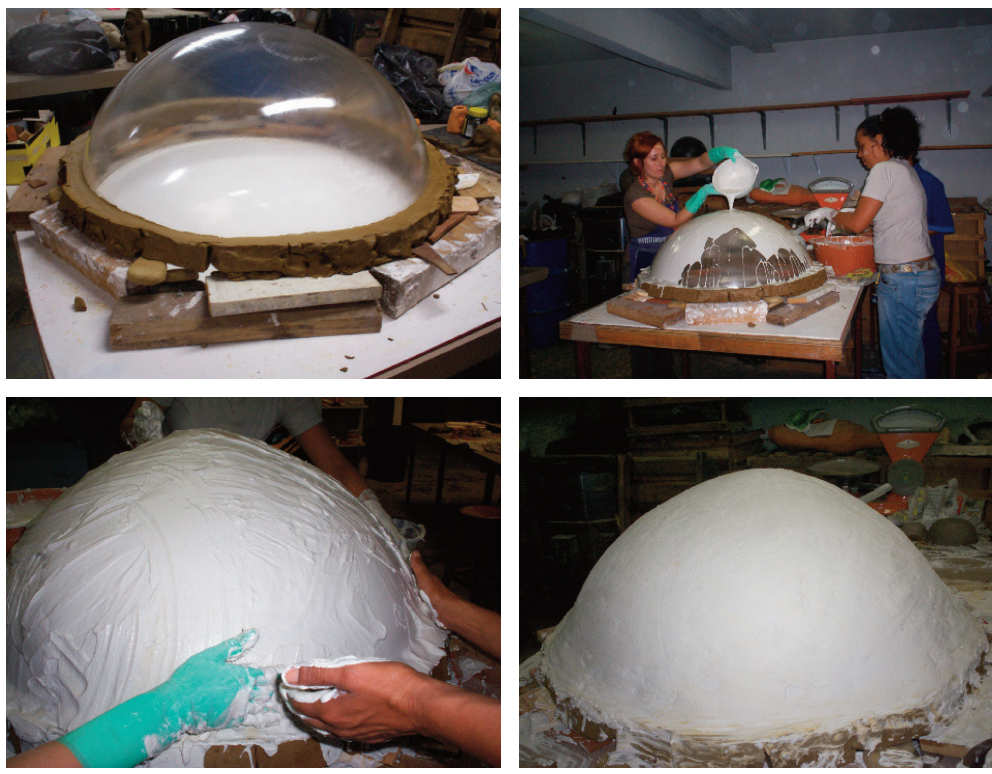

Figura 7, 8, 9 e 10 - Processo de criação de um molde de gesso. Atelier de Cerâmica do Instituto de Artes da Unesp, 2008. Foto: Flávia Leme.

A partir do tamanho de molde selecionado e com a placa já inserida nele, é que podemos definir e começar uma peça. Deste ponto em diante começaram as interferências - fazemos com que se transformem em peças únicas, apesar de pertencerem à mesma série (Figuras 11, 12, 13 e 14).

Todas essas etapas demoraram muitos dias, às vezes semanas ou meses, dependendo da dimensão da peça, das condições climáticas e de armazenamento. Não há como apressar sem correr o risco da peça se quebrar, o que conseguimos é apenas retardar o processo de secagem embalando-a com muitos sacos plásticos para que a água não evapore. Observe-se que todo esse processo está muito mais ligado a um nível de entendimento empírico, do que teórico. Imagino que seja um tanto complicado visualizar tudo o que foi dito, sem ter tido a vivência desses momentos e processos de transição sempre possíveis de acontecerem - principalmente durante a quei- 

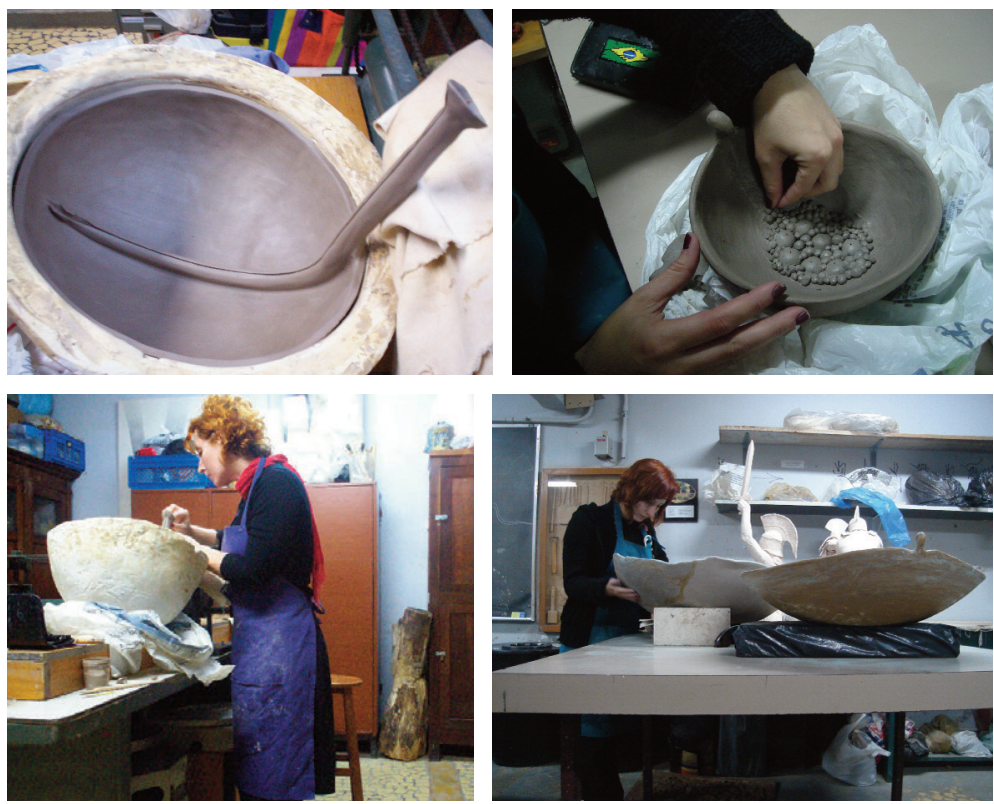

Figura 11, 12, 13 e 14 - Processo criativo das peças. Atelier de Cerâmica do Instituto de Artes da Unesp, 2008. Foto: Flávia Leme.

ma, onde podemos controlar apenas a gradação (os patamares) e o limite máximo da temperatura. ${ }^{3}$

Fazer cerâmica é um processo solitário e silencioso. Muitas vezes, precisamos concentração e muita paciência para desenvolver cada uma das peças. É também um constante aprendizado, uma constante troca e doação, de tempo, energia e disposição. De muitas formas, é uma atividade terapêutica e transformadora. Aprendemos com a cerâmica que o mais importante não é apenas o resultado

3 Aqui me refiro especificamente aos fornos elétricos, pois foi apenas com eles que produzi minhas peças para queima e biscoito (também chamado de monoqueima, o biscoito é a primeira queima a baixa temperatura, em torno de 800o C, como preparo para esmaltar a peça, que depois volta a ser queimada em temperatura bem mais alta, cerca de 1.200 o C). Nos fornos elétricos é possível programar o aumento gradual da temperatura até atingir a temperatura máxima prevista. 
final (muitas vezes surpreendente), mas sim todo o processo, pleno de aprendizagem e descobertas gratificantes.

\section{As Mulheres recipientes}

"As palavras de um artista devem ser entendidas sempre com cuidado... O artista que discute o suposto 'significado' de seu trabalho está, normalmente, descrevendo a faceta literária de seu tema. O âmago de seu impulso original deve ser encontrado, caso exista, em seu próprio trabalho. Assim, o artista deve dizer o que sente..."

Louise Bourgeois

E é com este mesmo cuidado, referido por Louise Bourgeois, que pretendo falar sobre meu trabalho. Não tenho a intenção aqui de limitar minha obra em algumas significações pretensiosas ou simplistas. Nesse livro pretendo apenas dar início a uma leitura poética, possibilitando que outras leituras possam ser feitas livremente sobre minhas peças.

Sobre meu processo criativo, penso que seja um assunto deveras complexo a ser tratado, pois na tradução de uma linguagem para outra pode haver ruídos que compliquem as leituras. Minha busca formal é expressa simbolicamente através do meu fazer artístico e relaciona-se diretamente com o material que emprego, no caso, a cerâmica, assim como também com meu próprio universo feminino e pessoal.

Em seu livro Acasos e criação artística, Fayga Ostrower (1999, p.7) descreve da seguinte maneira o processo criativo: "A fonte de criatividade artística, assim como de qualquer experiência criativa, é o próprio viver. Todos os conteúdos expressivos na arte, quer sejam de obras figurativas ou abstratas, são conteúdos essencialmente vivenciais e existenciais". Logo, ao se falar da própria obra, devemos necessariamente inserir a ótica pessoal daquilo que nos cerca, 
nossos questionamentos e ansiedades, vinculando sempre a cultura em que vivemos.

Mas ainda não conseguimos chegar ao âmago da questão de como surge ou nasce uma obra de arte e, para sermos realistas, esta é uma questão que estará sempre em aberto. Tanto Fayga quanto Louise, ambas conceituadas no meio artístico, colocam essas inquietantes indagações que povoam as mentes de qualquer criador. Fayga questiona-se como e por que surge a inspiração, de que parte profunda da sensibilidade ela emerge da mente do criador. "O senso de mistério e de surpresa que acompanha a espontânea visão de formas, configurando algo já pressentido, porém até então informe, é comentado por todos os criadores, artistas ou cientistas" (Ostrower, 1999, p.8). Já Louise Bourgeois, certa vez em uma mesa-redonda entre um grupo de artistas, escritores e curadores mediados por Robert Motherwell, também lançou a pergunta sobre o que exatamente pode provocar o nascimento das obras de arte e qual seria o seu impulso primário. "O que faz o artista trabalhar? É para fugir da depressão (preenchendo um vazio)? É para registrar confiança ou prazer? É para entender e solucionar um problema formal e reordenar o mundo?" (Bourgeois, Bernadac e Obrist, 2000, p.64). $\mathrm{Eu}$, como artista e pesquisadora, penso que as indagações e inquietações sempre povoarão a mente de qualquer criador. A grande diferença é que, para o artista, exteriorizar suas idéias é quase como uma necessidade vital. O processo criativo é também produto das bagagens experenciais e sensíveis de cada pessoa e desponta na medida em que dedicamos nosso tempo na pesquisa, seja ela teórica ou prática. É portanto, uma busca contínua, subjetiva que exige determinação e disposição.

$\mathrm{Na}$ arte, ainda buscamos as respostas para muitas perguntas. Os artistas utilizam e experimentam diversos materiais para que seja possível descobrir o enigma que deles se desprende, para que seja revelado o invisível e o indizível através da arte.

Para tornar visível aquilo que busco, usufruo da terra, artisticamente, dando vida ao barro. Transformo o barro em objetos instigadores e provocadores, aguço os olhares e as insinuações no 
sentido do erótico, fálico, vaginal, visceral, enfim, do sumariamente humano.

Em Mulheres recipientes, o conjunto de todas é, na verdade, apenas uma única mulher. Cada escultura representa simbolicamente todas as mulheres. A argila fêmea, a mulher-pote, do barro viemos e ao pó voltaremos. As formas de mulher incorporadas e moldadas no barro, resolvidas a serem potes, contidas no bojo. O corpo da mulher, tanto na antiguidade quanto nos dias atuais, ainda mantém o significado real de recipiente de vida, líquidos, sangue, dores, sentimentos e sensações. Seres femininos que na sua essência são mutáveis, moldáveis, impermeáveis, elásticos, sustentáveis, portadores e cíclicos - o ciclo menstrual, o ciclo lunar, o clico gestacional, o ciclo cerâmico. A força da Mãe Terra, a Pachamama, invocada nas silhuetas, nas formas femininas, nas curvas, no ventre fertilizador.

As mulheres potes, recipientes do vir-a-ser, conteúdos a espera de um preenchimento, formas que sugerem formas de mulher, formas que sugerem formas de bacias, formas de fôrmas, formas feitas com fôrmas. Os potes, as vasilhas, os recipientes, os jarros, as tigelas, os conteiners, as bacias, os vasilhames, as cumbucas, os caldeirões, as cuias, os vasos, as panelas de cerâmica. Tudo está ligado ao universo feminino, todos esses elementos estão presentes no cotidiano das mulheres há milênios de anos: a mulher como que agrega_dor(a) da família, como a cozinheira, a que amamenta, a que alimenta, a que carrega a vida em seu ventre. Aquela que é acolhe_dor(a).

(...) a fêmea - a terra - as entranhas - o estrume - o ovo - o ninho - a semente - a bosta - a massa - matéria vida - a força - a seiva - do capim verde - o calor - bosta terra - bosta dor - bosta mulher - fêmea força - fêmea amor.

O que faz desencadear no artista uma linguagem, um caminho, no meio de tamanha diversidade de materiais? Sons, palavras, vegetais, peles, fibras, rochas, pedras, terras? A matéria orgânica e a matéria inorgânica? O que se vê e o que não se vê? (Tostes apud Hennig, 2008, p.4) 
E, olhando para minhas peças como uma sequência, posso perceber que a série Mulheres recipientes teve duas fases distintas, entremeadas por uma fase de transição. Na primeira fase, havia ainda a preocupação com as formas parecidas com os corpos reais, aproximando-se da figuração, por mais que a idéia de recipiente já estivesse presente desde o início. Isto fica claro na peça Recipiente I (Figura 15), onde todo o corpo feminino é transfigurado em uma forma de banheira. A cabeça está voltada para dentro, para o vazio do corpo, as mãos seguram firme as pernas entre os joelhos. Em Recipiente II (Figura 16), as partes do corpo completamente soltas, presas por um arame, passam a impressão de uma desfragmentação estruturada, estancada por fortes amarras, adormecendo dolorosamente todas as partes. Vemos que nas peças Recipientes IV, V, VI e XI (Figuras 17, 18, 19 e 24), as formas alongadas afunilam-se entre as pernas e os braços voltam-se para dentro, focando o local ventral, sugerindo pequenos ou grandes lábios ondulantes. A fase intermediária fica evidente nas peças Recipientes VII, VIII, IX e X (Figuras 20, 21, 22 e 23). A forma redonda do recipiente está definitivamente presente nessas peças, porém ainda mantendo a preocupação da figuração, nas feições dos rostos e cabeças: olhos, bocas, narinas. Como num salto, já na terceira fase, deixei de representar as cabeças figurativamente, mudei a escala deixando-as desproporcionais, se comparadas a uma representação naturalista. Porém, enfatizando ainda mais a forma do recipiente (Figuras 25 a 41). Ora as cabeças são pequeninas, ora possuem um longo pescoço fálico - nesta fase, comecei a inserir também formas que sugerissem o corpo masculino, mas ainda assim, o feminino está presente, seja na forma esférica dos seios, ventre ou quadris, seja na própria forma redonda do recipiente. O predomínio do redondo é o que mais interessa neste momento. Tanto é que nas peças mais recentes, quase não há nada além das formas circulares, redonda, ovais, óvulos e ovos. É certo que existem em algumas espinhentos pregos espetados, que muitas vezes podem sugerir uma referência fálica, ou uma forma de agressividade, mas sua essência de recipiente é mantida em todas peças, como objetos cíclicos que se repetem, sem serem iguais. Como uma narrativa mítica, retornando sempre ao seu início. 
Nesse ciclo contínuo, todas as formas redondas se mesclam com as texturas, as vicissitudes, as nuances, pequenas variações de volumes, de curvas, de cores, de gestos, velando e revelando os côncavos e os convexos das esculturas. As justaposições, as fendas e os buracos, as dobras, as estrias e as rachaduras. A abertura que leva ao útero, o útero que leva a válvula de escape, a vulva, a vagina, a caverna, o interior, o templo sagrado.

E, para um sonhador de palavras, que paz na palavra redondo! Como ela arredonda serenamente a boca, os lábios, o ser do alento! Pois isso também deve ser dito por um filósofo que acredita na substância poética da palavra. E que alegria professoral, que alegria sonora começar a aula de metafísica, rompendo com todos os estaraí, dizendo: 'Das Dasein ist rund!' O ser é redondo. E depois esperar que o ressoar do trovão dogmático se acalme sobre os discípulos extasiados. (Bachelard, 1993, p.241)

A redondeza do ser/ente feminino, na forma oval dos seios, do umbigo, do ventre, da bacia, dos ovários, dos óvulos, do ovo - o redondo. Minha pele presente na superfície da argila. A forma de meu corpo inserida nas peças, como uma troca, uma simbiose, uma ligação entre minha vivência de mulher, minha relação com o espaço, com o mundo, com meu próprio corpo. Minhas esculturas são parte de mim, são como parte de todas as mulheres, pois somos como recipientes, na medida em que nós, as mulheres, somos todas recipientes de outros seres, carregamos dentro de nós a dor e o amor de sermos biologicamente feitas para dar vida - recipiente gera_dor, cria_dor, acumula_dor, revela_dor, fertiliza_dor, germina_dor...

Essas são as minhas peças. Esse é o meu modo de traduzir o que vejo.

Sobre esta série de esculturas Mariza Bertoli, ${ }^{4}$ faz suas considerações críticas

4 Entrevista concedida à autora em 15/05/2009. 
As mulheres recipientes de Flávia Leme situam-se no limiar entre a arte e o artesanato; assumem, na contemporaneidade, o apelo identitário ao ancestral. Embora busquem a forma nova, não escondem a ligação profunda com a tradição de produzir os utensílios para dar de beber e comer, para cozinhar, para guardar as ervas, preparar os remédios. Ela mesma diz da sensação de religar-se com os ancestrais ao praticar essa arte antiga. De um modo meio místico, busca os elos perdidos. Suas esculturas revelam, mais que tudo, a intimidade com a prática da cerâmica, e o prazer no trato com a matéria primordial - a carne da Mãe Terra. Os antigos nos ensinaram que ela dá à luz e depois, recebe as sementes dos que já foram, para preparar a nova colheita. A morte humana, natural, tem casa - coração taça, retorna ao ventre da mãe. No regime lunar do imaginário, o modo feminino, eufêmico e generoso, tem na copa-coração o seu símbolo fundamental. Sob a luz da lua todas as formas continentes se equivalem, o ventre, a casa, o túmulo, a caixa, o vaso, a panela, e todas supõe o tempo como tema recorrente, tempo de nascer, tempo viver, tempo de morrer, de curar, de cozinhar. Supõe abrigo e aconchego, pois sob o manto da noite todos os filhos são iguais, não há polaridades, nem fundamentalismos. Os objetos escultóricos de Flavia Leme, regulares, côncavos, quase sempre divididos ao meio por um sulco, sugerem ainda a questão dos gêmeos primordiais. A plenitude que há em cada um de nós, o masculino e o feminino juntos. O caminho desse reconhecimento pode ser espinhoso e a artista acentua essa aspereza, cravando pontas agudas nesse espaço de vivência, nas interfaces sobrepostas em atrito. A presença insistente de uma pequena cabeça pelada, que parece nascer da peça semiesférica, poderia simbolizar uma confissão de humildade diante do que se pode colher na copa da vida, reverência ao destino... Ao tempo domesticado para enfrentar o medo da morte? A densidade do continente é o oco, o próprio vazio. Porém, esse oco é cheio de sonhos e presságios, como um caldeirão borbulhante onde se prepara a poção mágica que alimenta a esperança. As Mulheres recipientes são como a copa que se enche e dá de beber, e quanto mais se bebe, mais ela se enche, como um coração pulsante de mãe amorosa. 

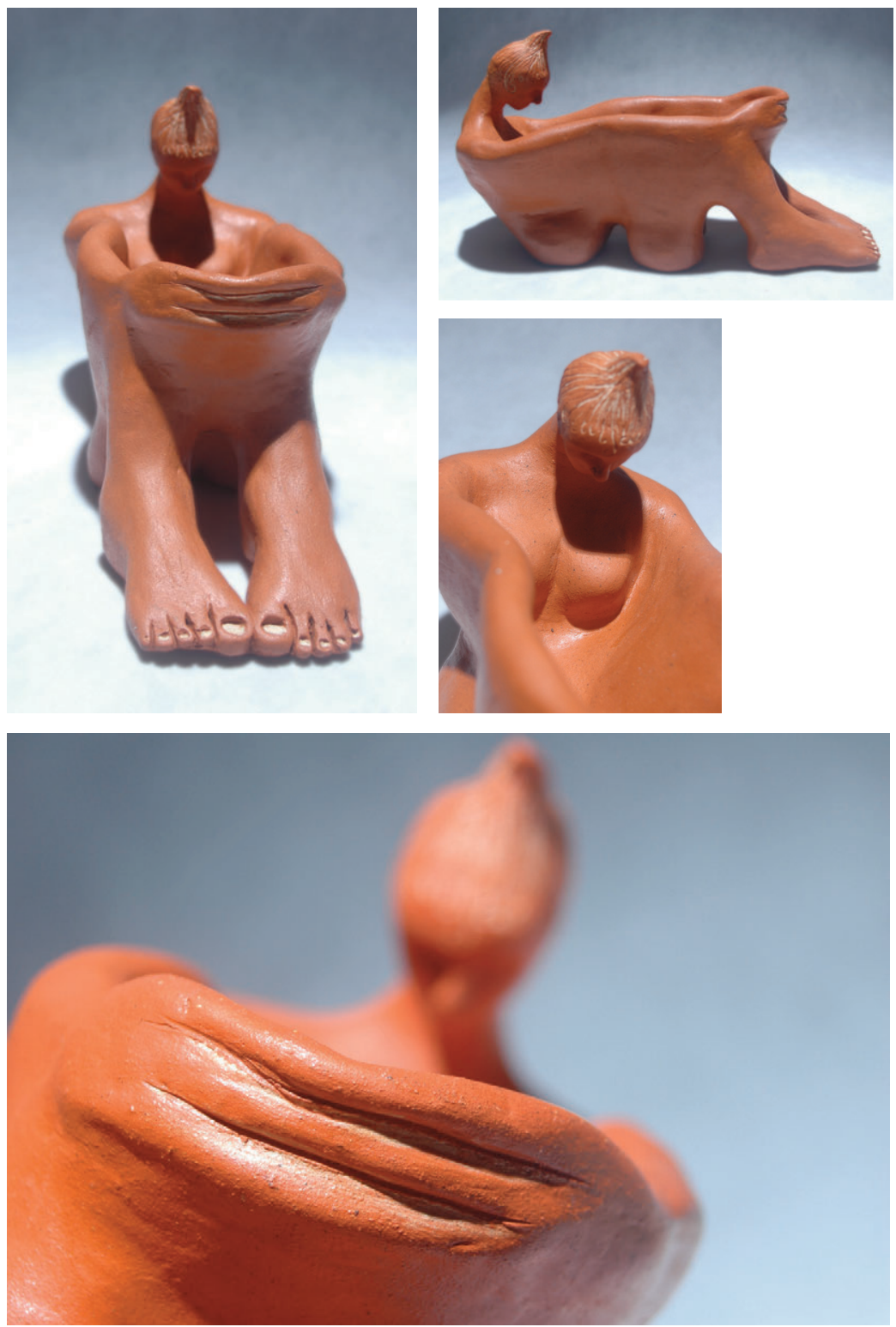

Figura 15 - Recipiente I (série Mulheres recipientes), 2002. Cerâmica, 20 x 13 x $10 \mathrm{~cm}$. Foto: Rafael Pillegi e Mariele Sousa. 

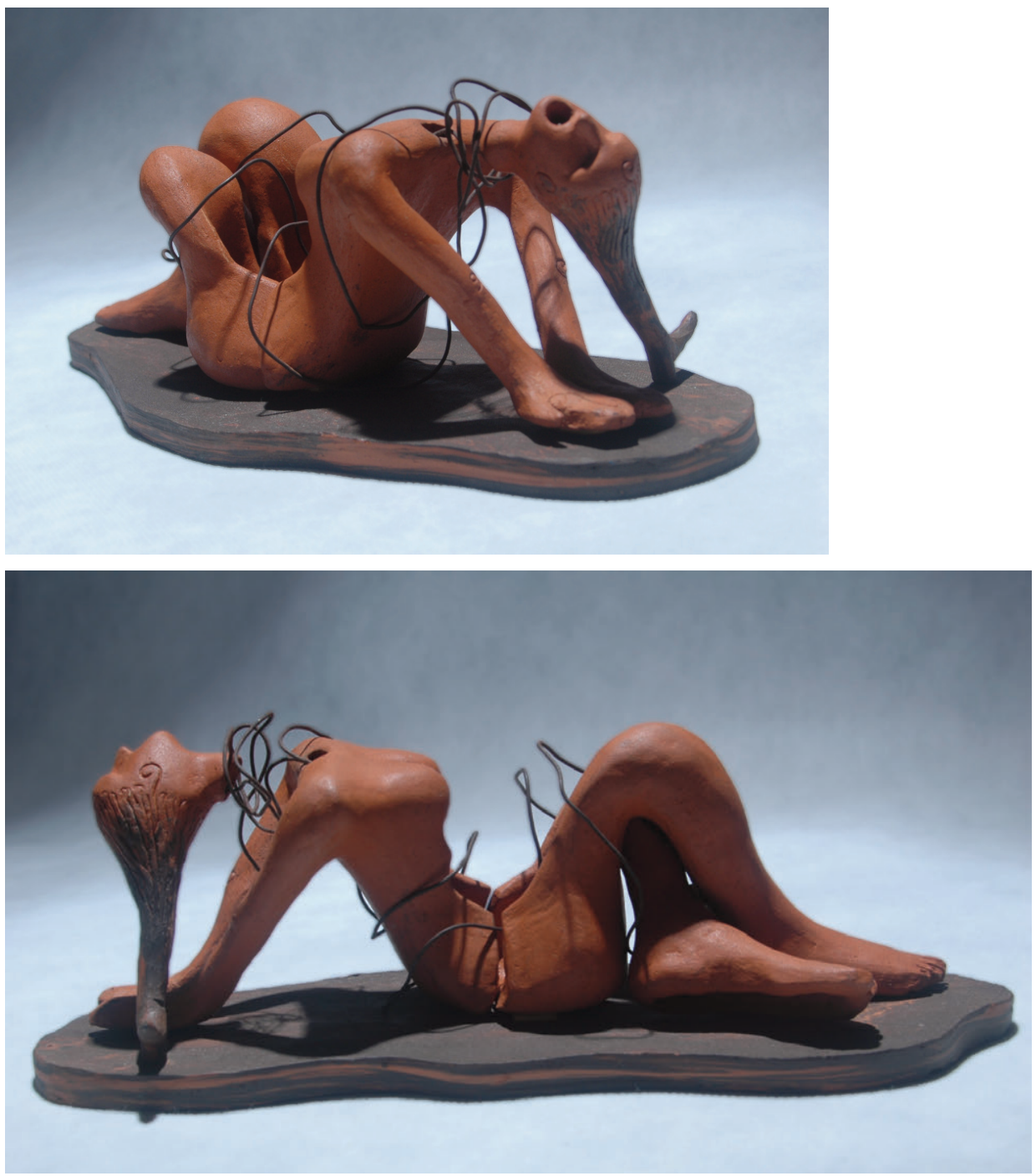

Figura 16 - Recipiente II (série Mulheres recipientes), 2002. Cerâmica, 23 x 14 x $11 \mathrm{~cm}$. Foto: Rafael Pillegi e Mariele Sousa. 

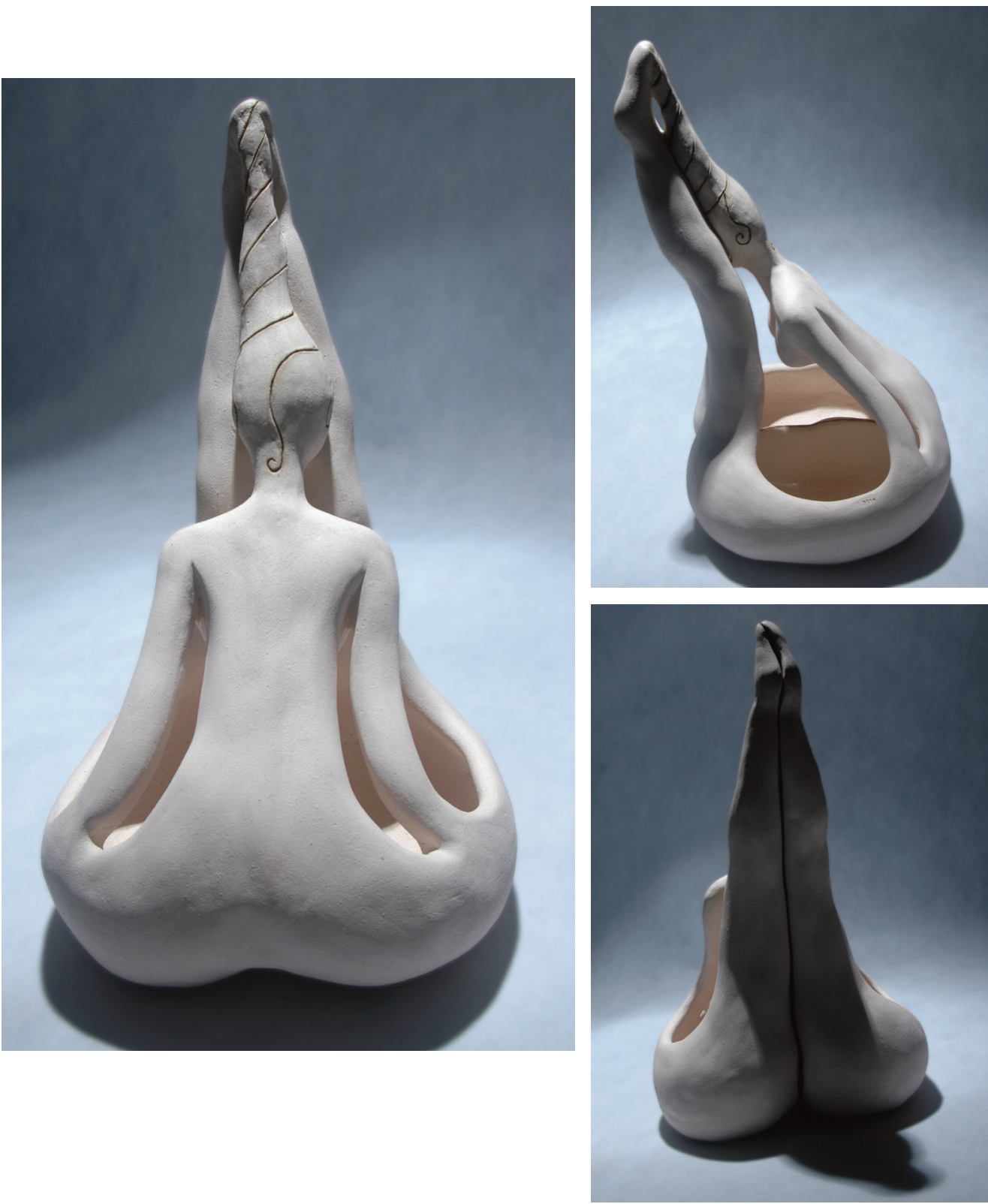

Figura 17 - Recipiente IV (série Mulheres recipientes), 2002. Cerâmica, 27 x 23 x $31 \mathrm{~cm}$. Foto: Rafael Pillegi e Mariele Sousa. 

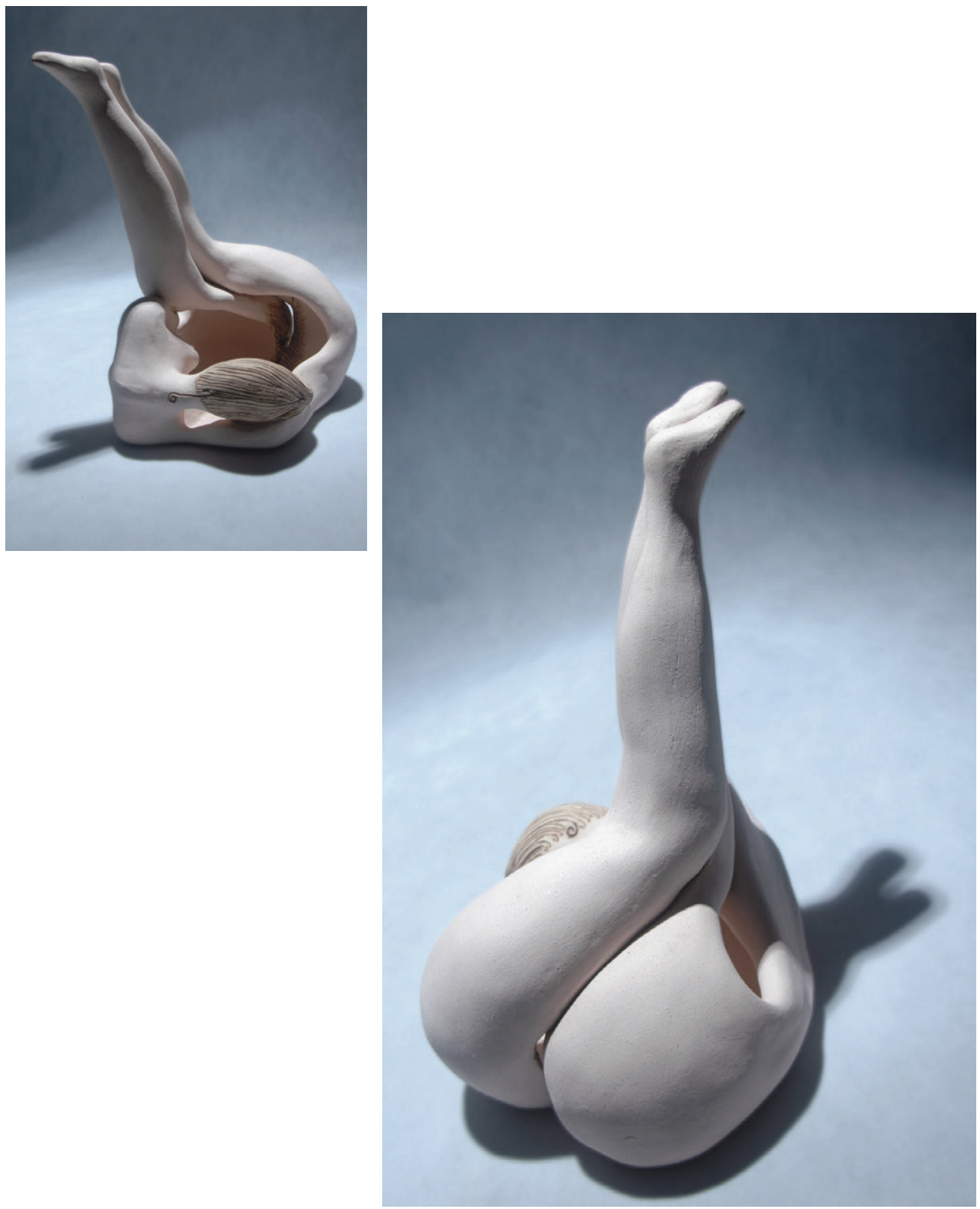

Figura 18 - Recipiente V (série Mulheres recipientes), 2002. Cerâmica, 28 × 21 × $32 \mathrm{~cm}$. Foto: Rafael Pillegi e Mariele Sousa. 

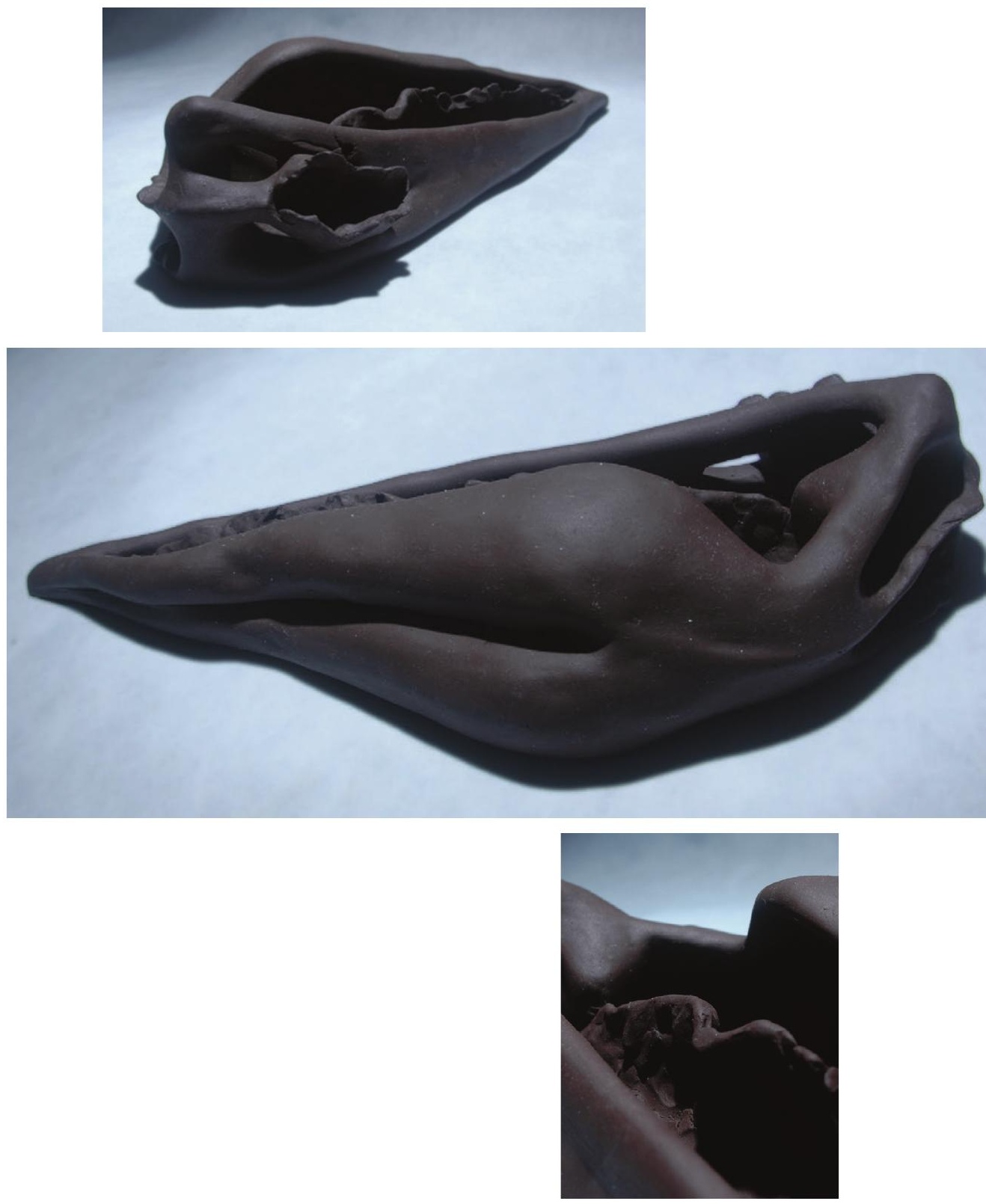

Figura 19 - Recipiente VI (série Mulheres recipientes), 2002. Cerâmica, 50 x 25 x $13 \mathrm{~cm}$. Foto: Rafael Pillegi e Mariele Sousa. 

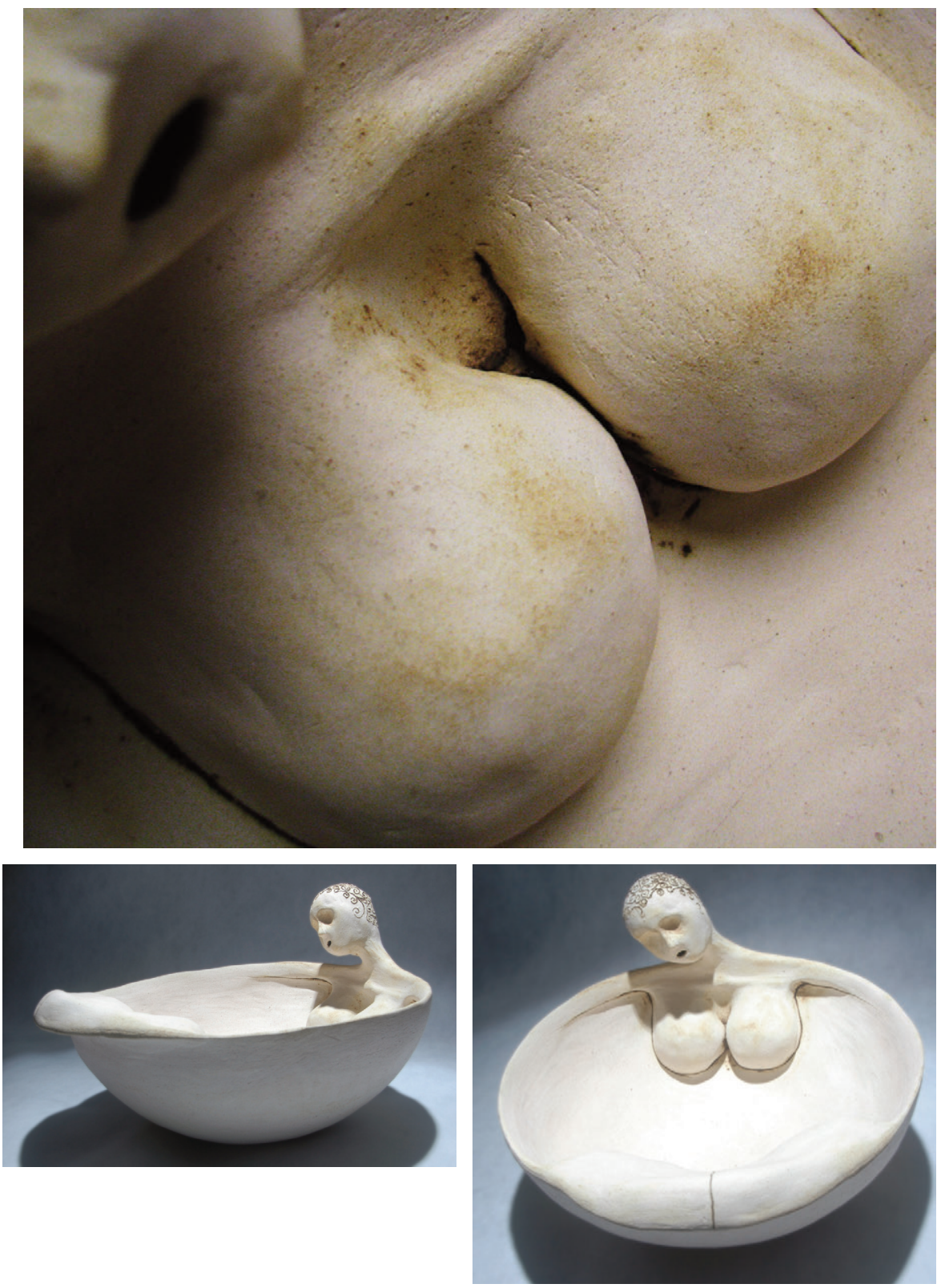

Figura 20 - Recipiente VII (série Mulheres recipientes), 2003. Cerâmica, 43 (diam.) x 20 (alt.) cm. Foto: Rafael Pillegi e Mariele Sousa. 

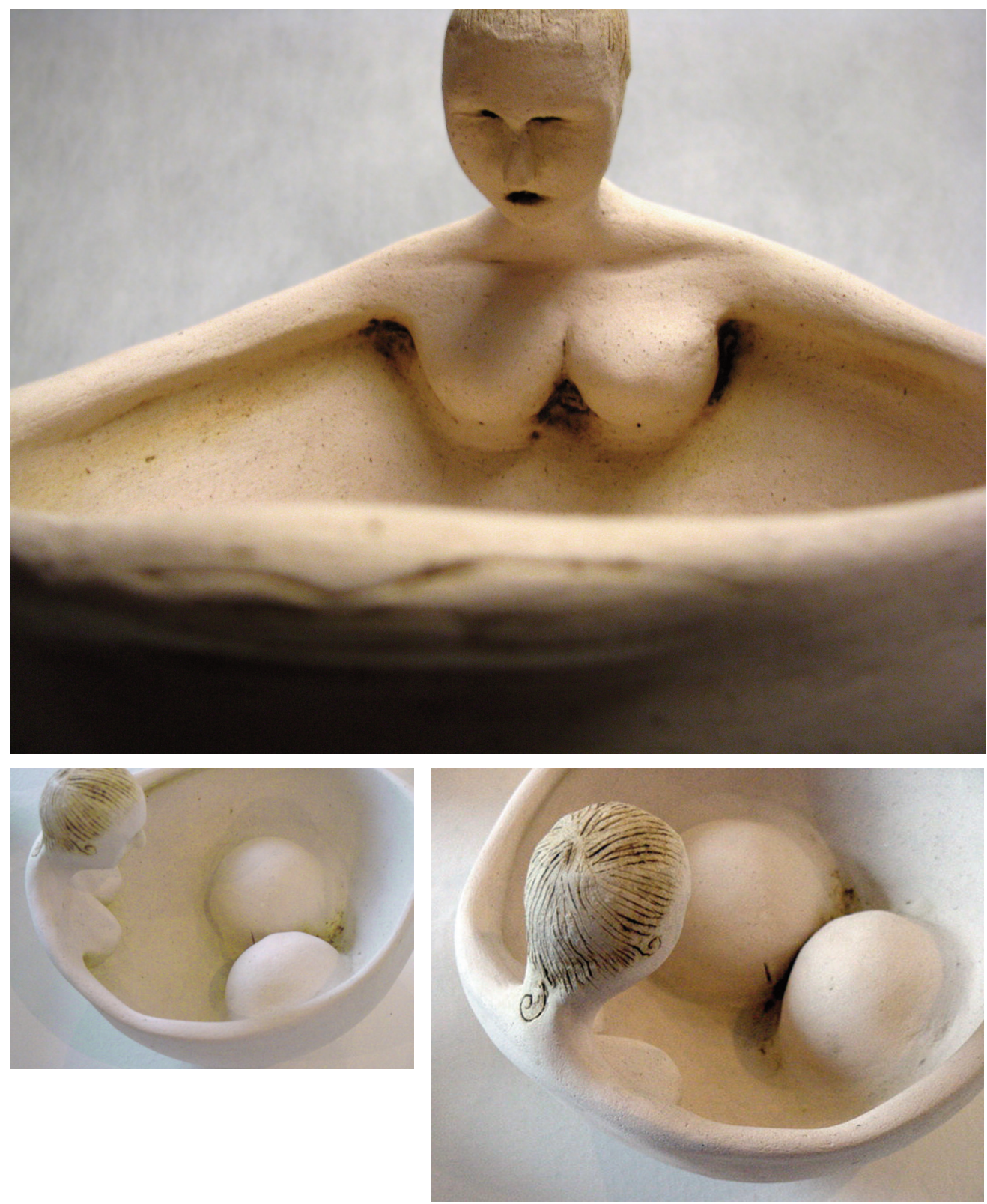

Figura 21 - Recipiente VIII (série Mulheres recipientes), 2003. Cerâmica, 25 (diam.) x 15 (alt.) cm. Foto: Rafael Pillegi e Mariele Sousa. 

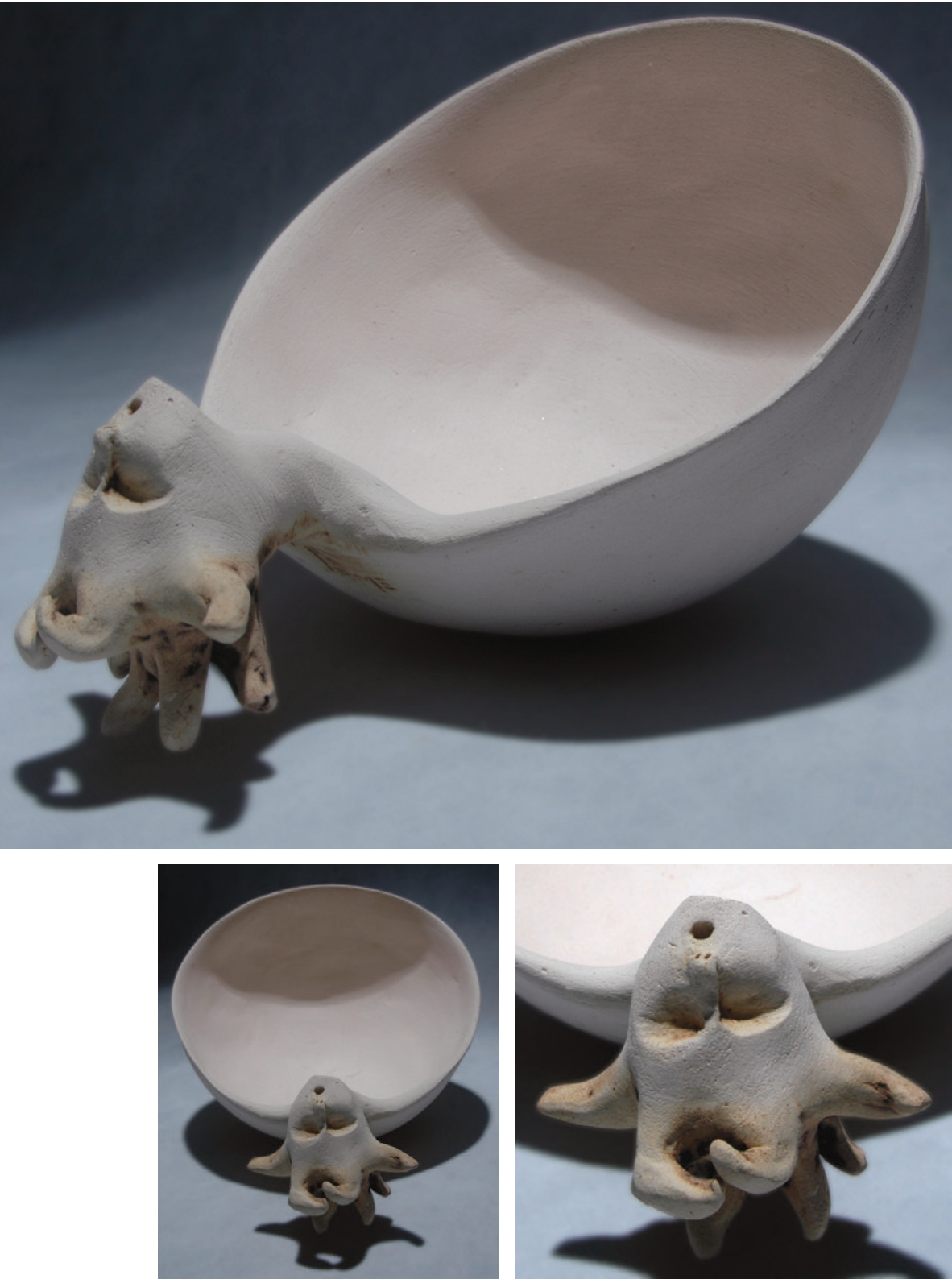

Figura 22 - Recipiente IX (série Mulheres recipientes), 2003. Cerâmica, 25 (diam.) x 13 (alt.) cm. Foto: Rafael Pillegi e Mariele Sousa. 

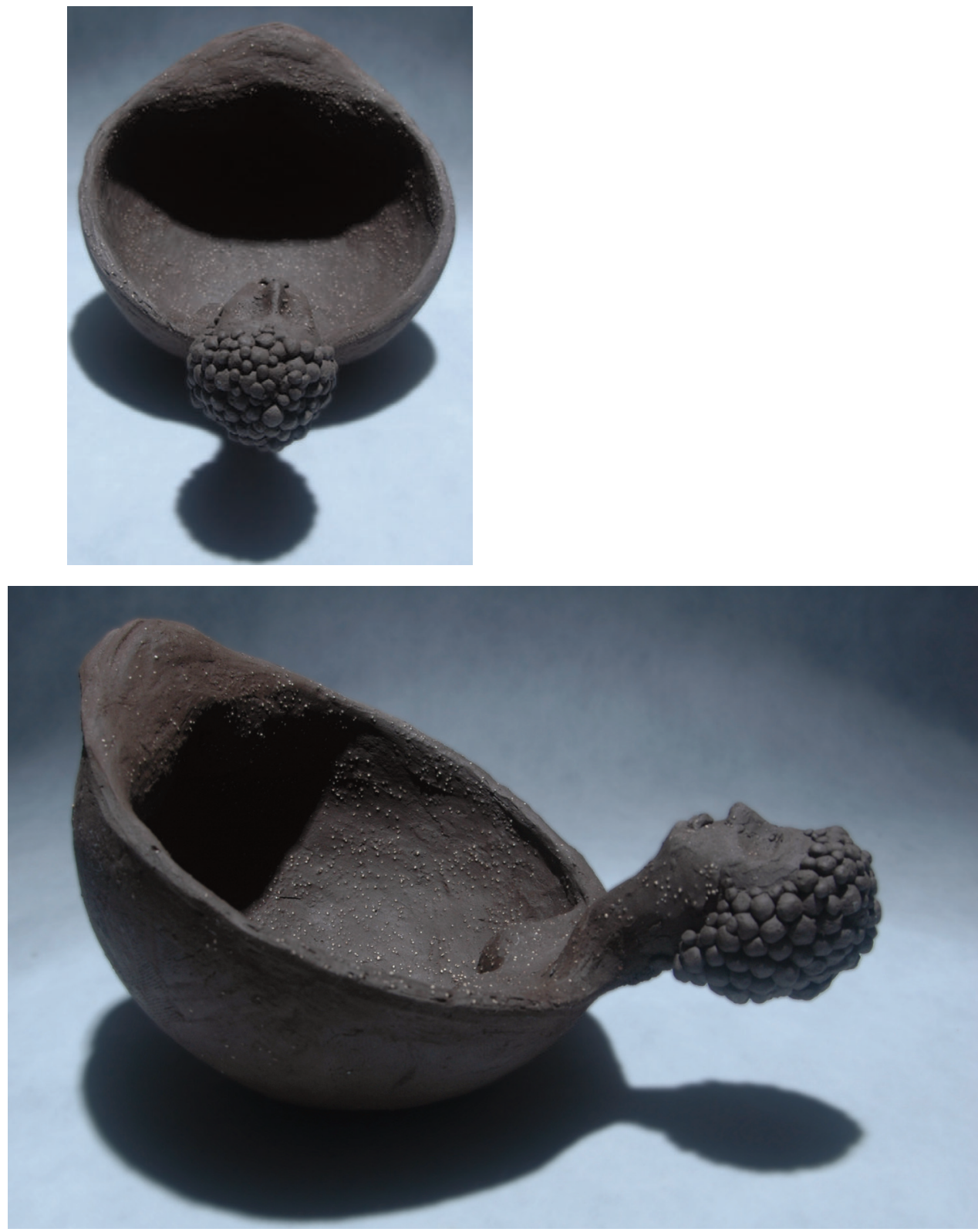

Figura 23 - Recipiente X (série Mulheres recipientes), 2003. Cerâmica,25 (diam.) x 13 (alt.) $\mathrm{cm}$. Foto: Rafael Pillegi e Mariele Sousa. 

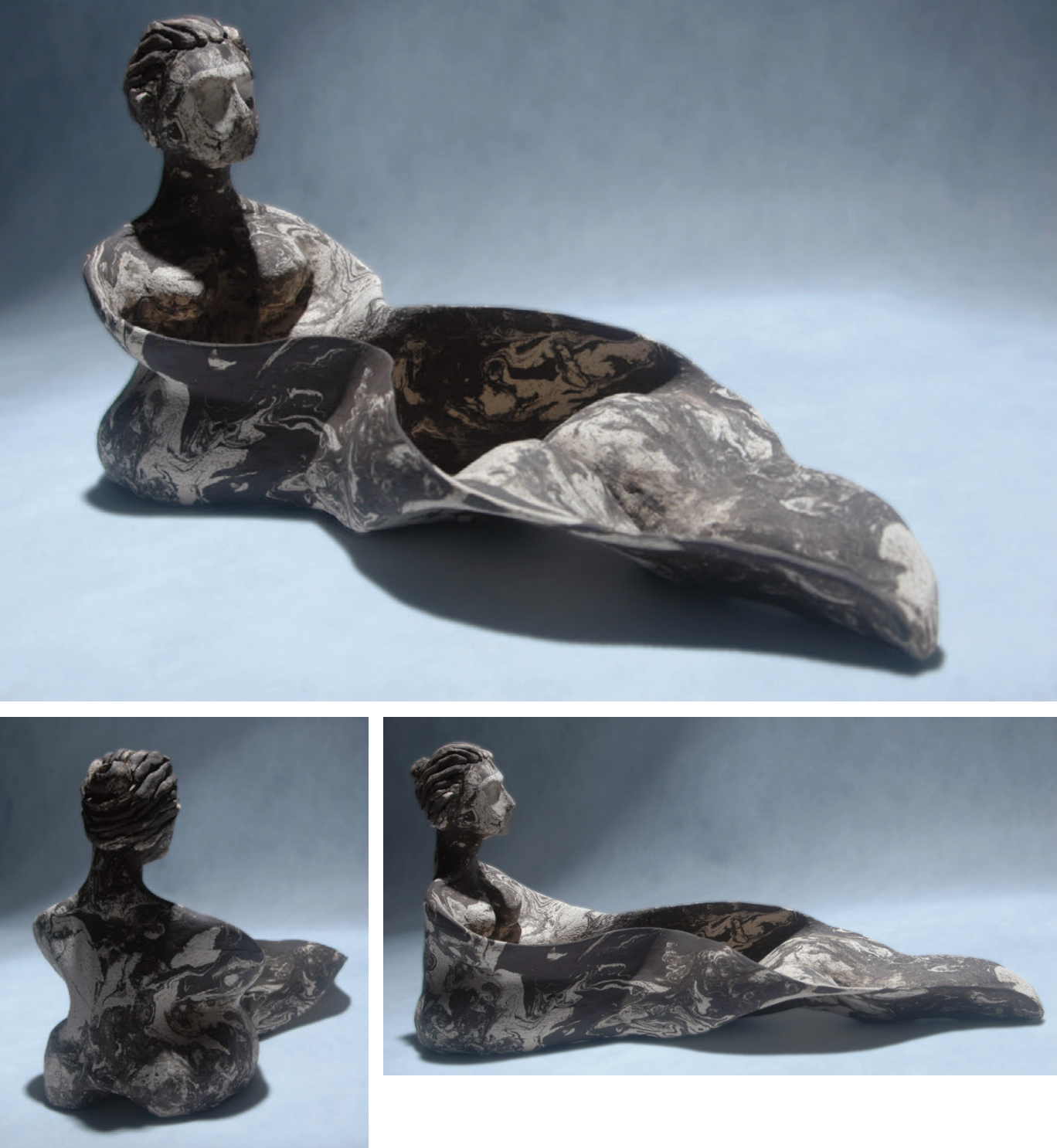

Figura 24 - Recipiente XI (série Mulheres recipientes), 2004. Cerâmica, 50 x 25 x $13 \mathrm{~cm}$. Foto: Rafael Pillegi e Mariele Sousa. 

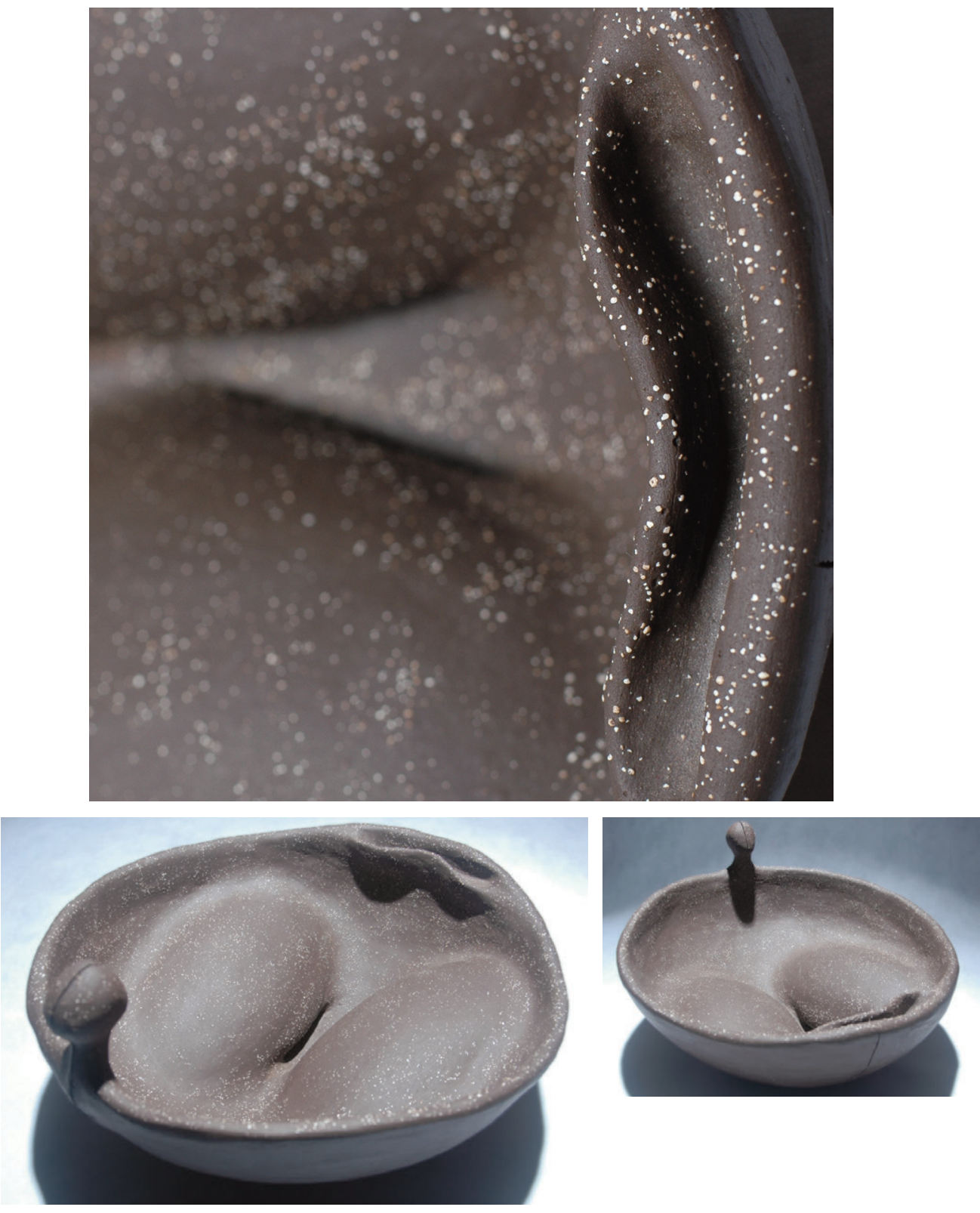

Figura 25 - Recipiente XII (série Mulheres recipientes), 2006. Cerâmica, 43 (diam.) x 20 (alt.) cm. Foto: Rafael Pillegi e Mariele Sousa. 

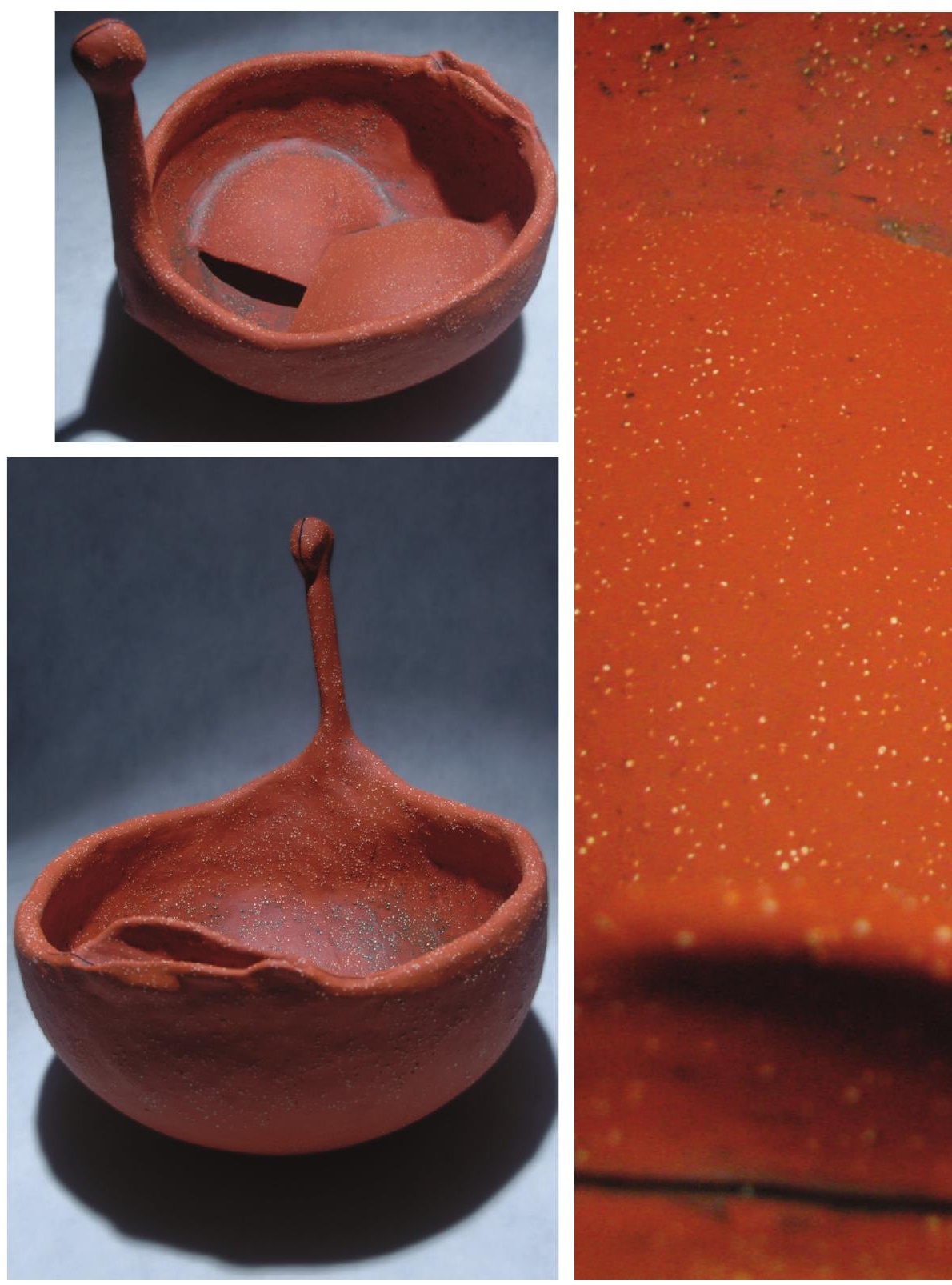

Figura 26 - Recipiente XIII (série Mulheres recipientes), 2006/07. Cerâmica, 43 x (diam.) x 40 (alt.) cm. Foto: Rafael Pillegi e Mariele Sousa. 


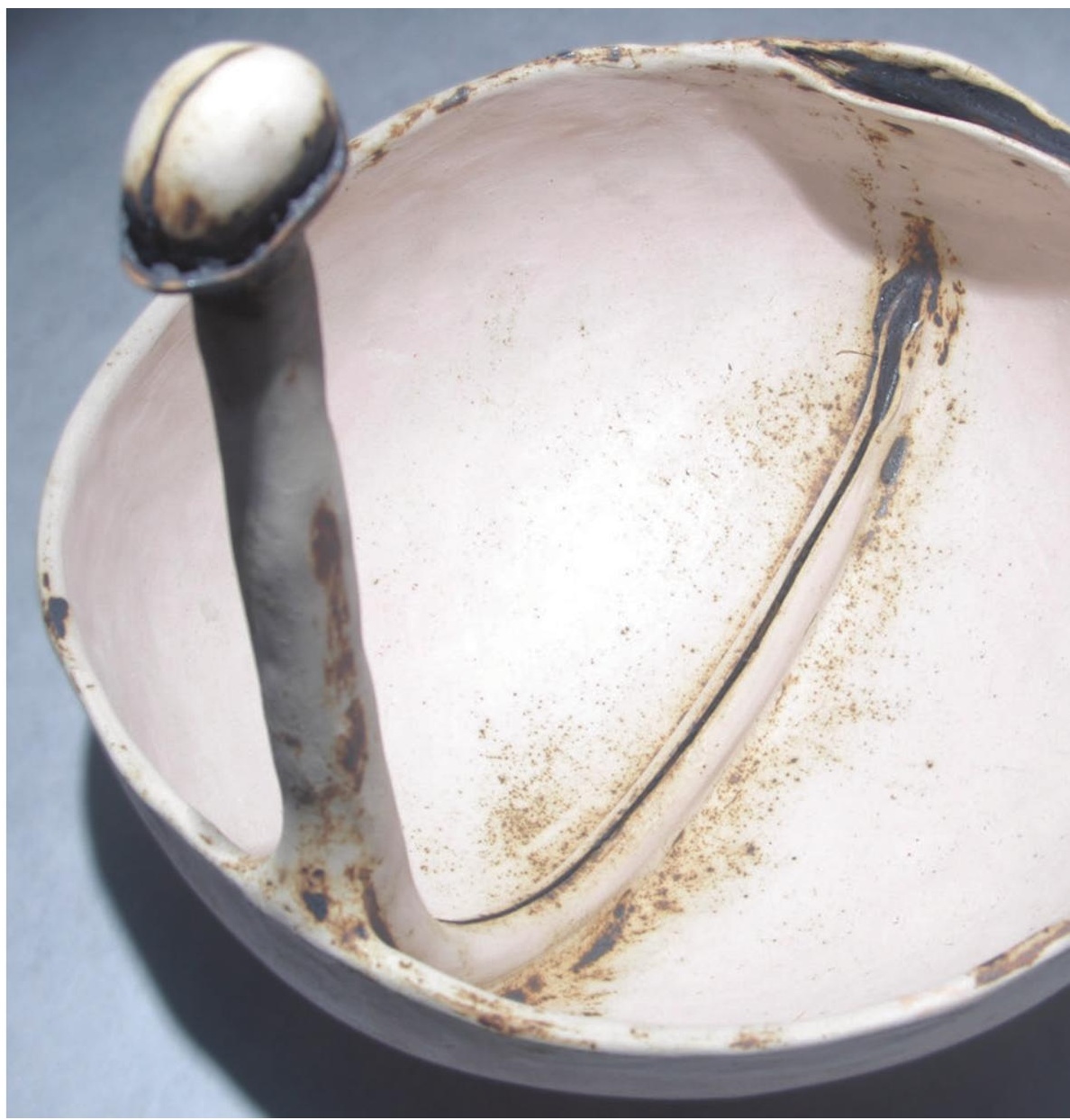

Figura 27 -Recipiente XIV (série Mulheres recipientes), 2006/07. Cerâmica, 45 x (diam.) x 59 (alt.) cm. Foto: Rafael Pillegi e Mariele Sousa. 

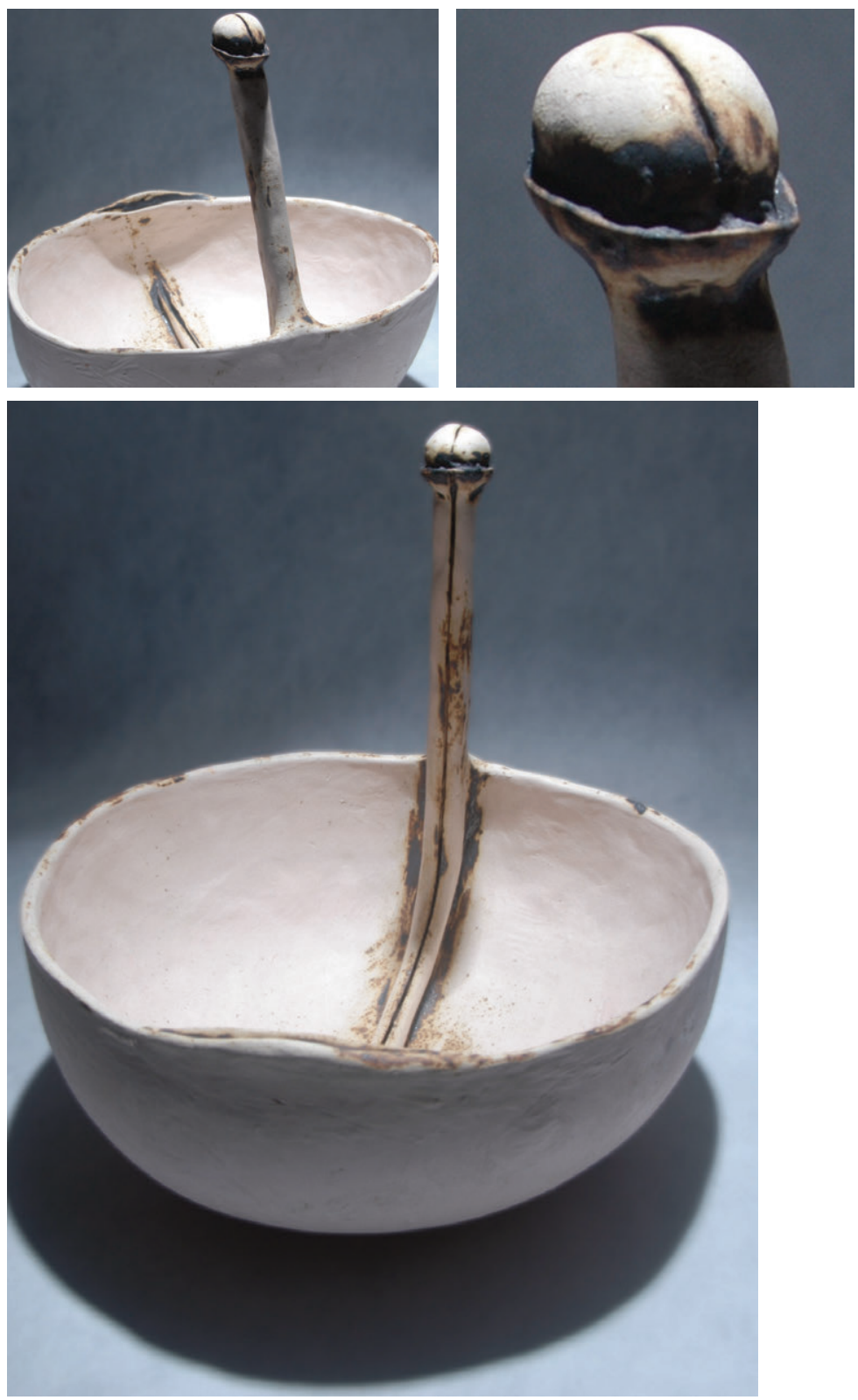

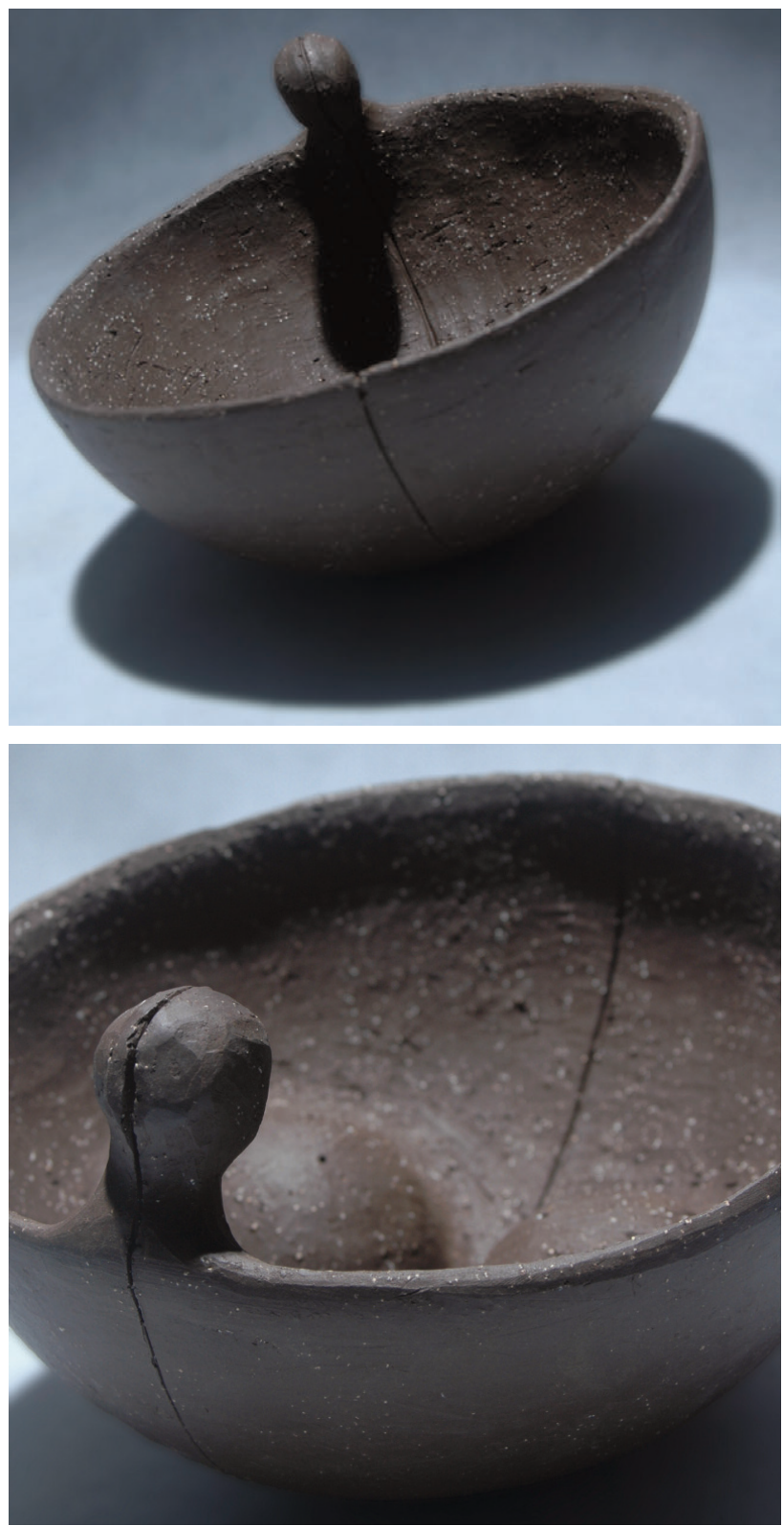

Figura 28 - Recipiente XV (série Mulheres recipientes), 2008. Cerâmica, 25 (diam.) x 13 (alt.) cm. Foto: Rafael Pillegi e Mariele Sousa. 

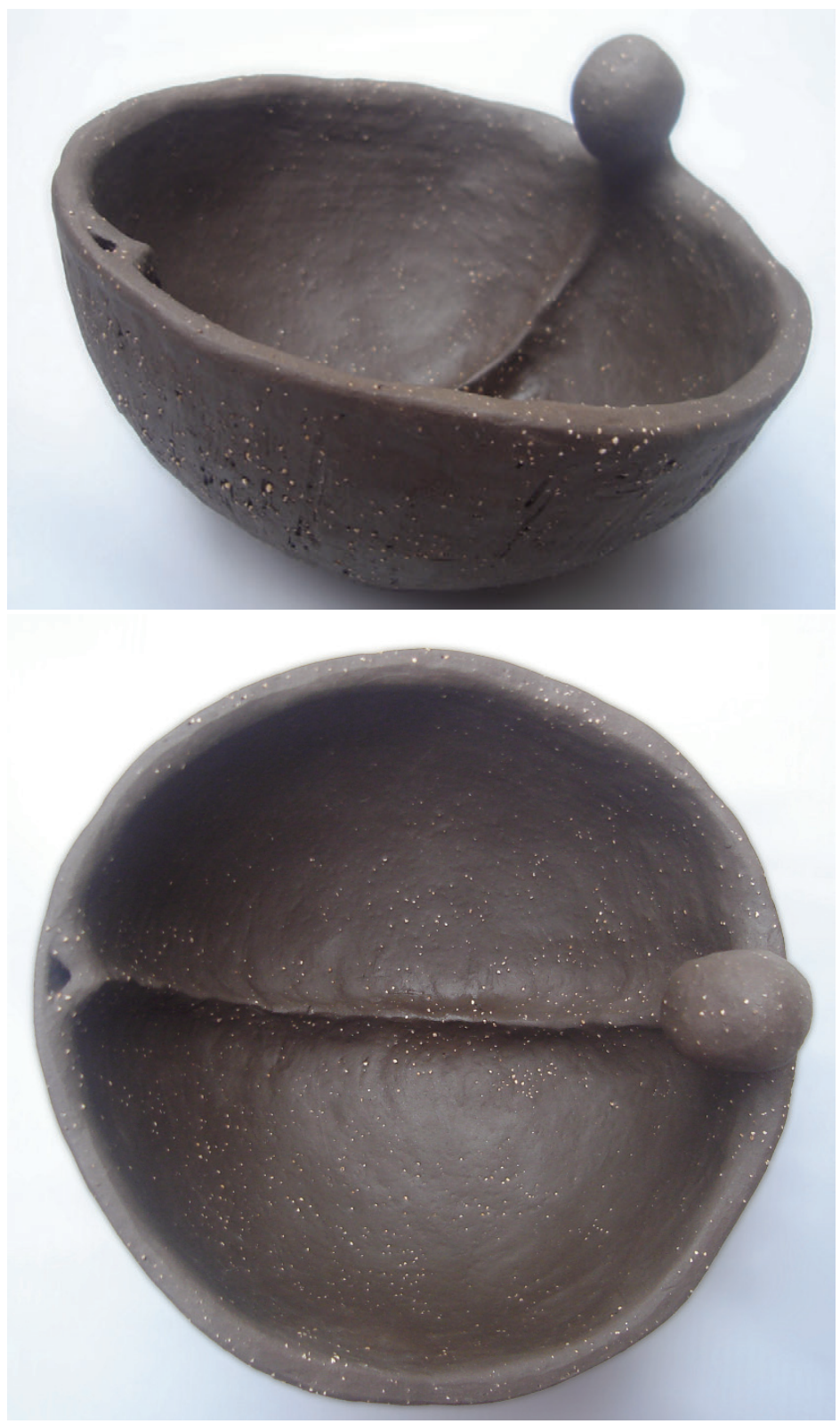

Figura 29 - Recipiente XVI (série Mulheres recipientes), 2008. Cerâmica, 15 (diam.) x 8 (alt.) cm. Foto: Rafael Pillegi e Mariele Sousa. 

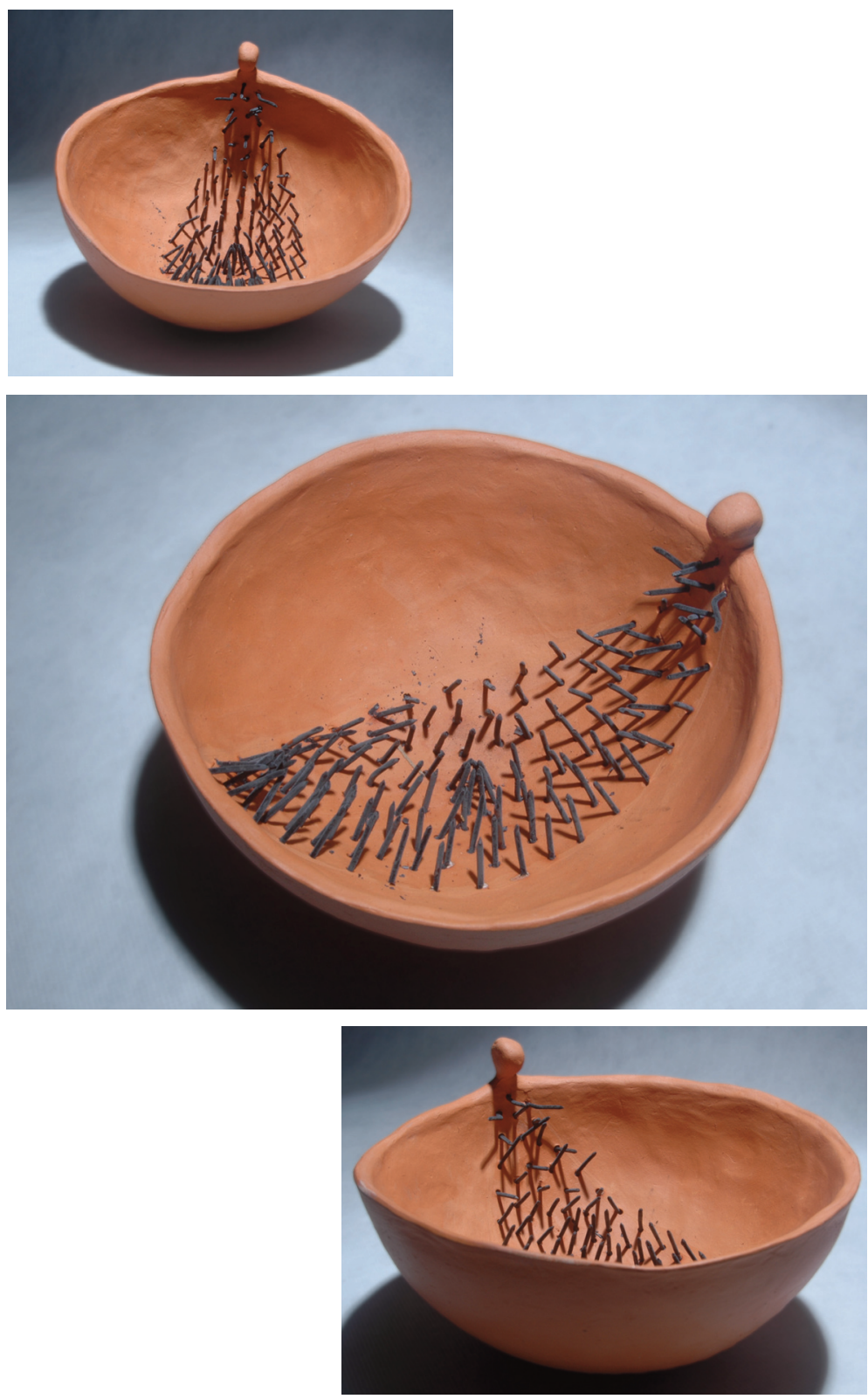

Figura 30 - Recipiente XVII (série Mulheres recipientes), 2008. Cerâmica, 23 (diam.) x 13 (alt.) cm. Foto: Rafael Pillegi e Mariele Sousa. 

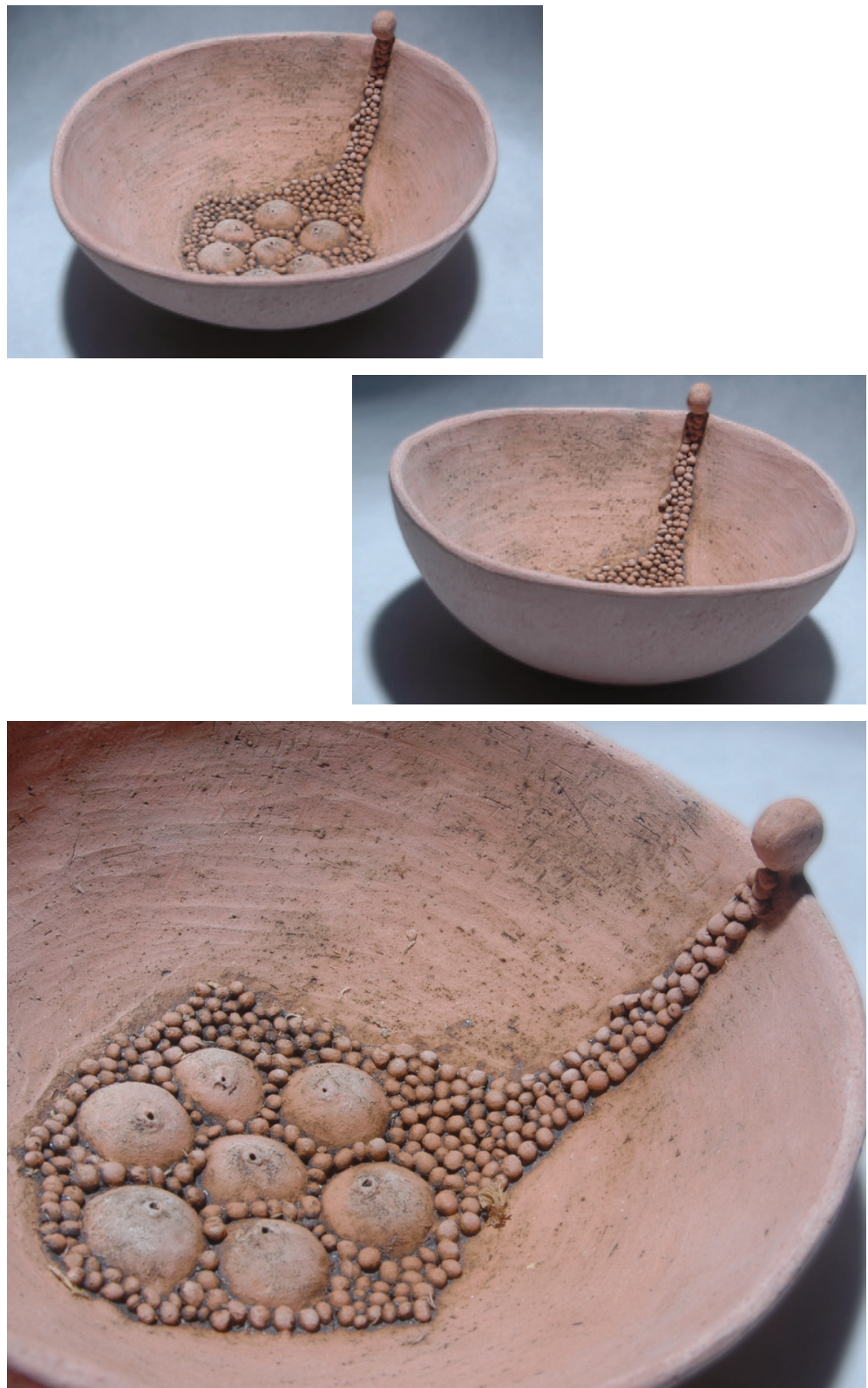

Figura 31 - Recipiente XVIII (série Mulheres recipientes), 2008. Cerâmica, 23 (diam.) x 13 (alt.) cm. Foto: Rafael Pillegi e Mariele Sousa. 

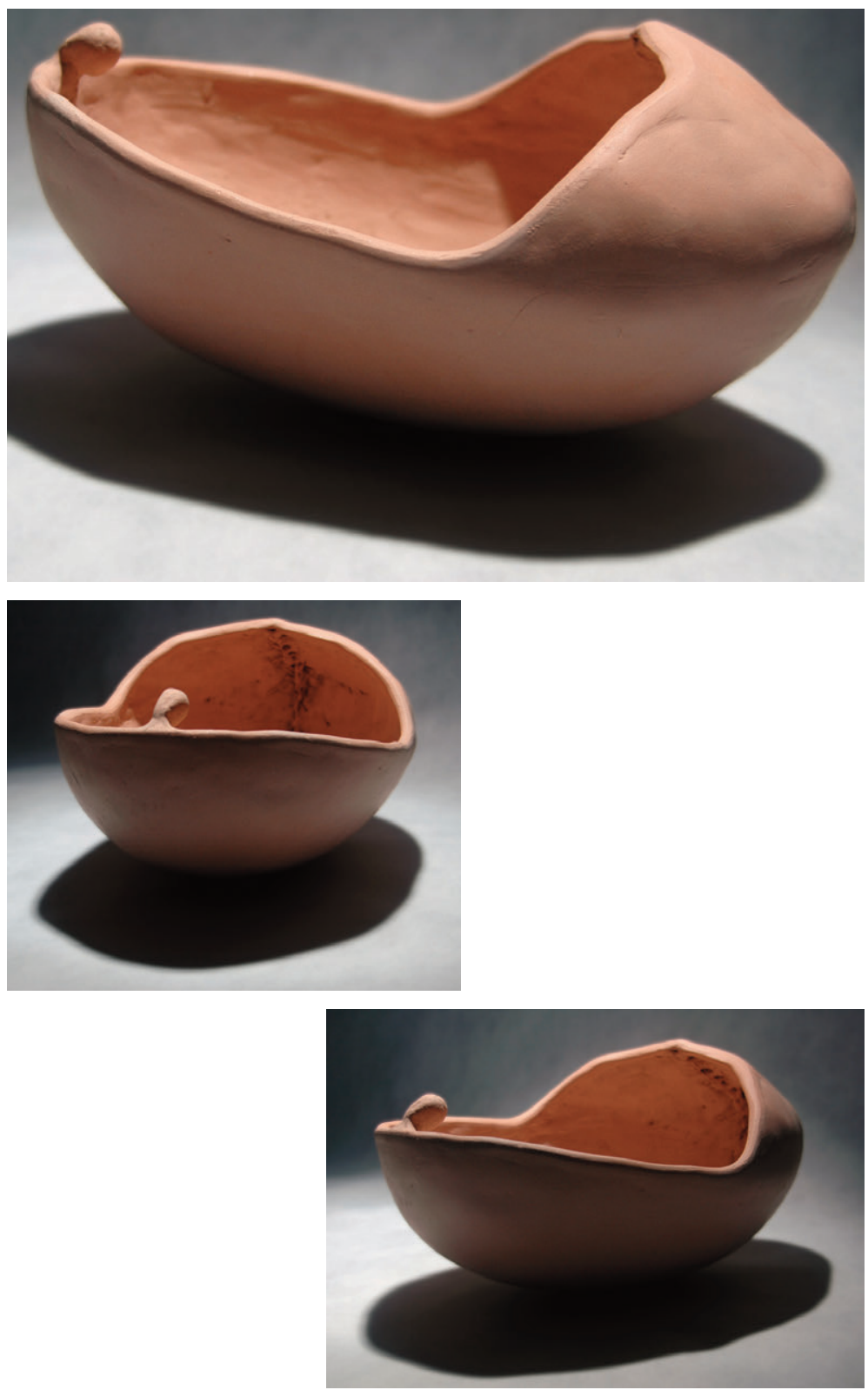

Figura 32 - Recipiente XIX (série Mulheres recipientes), 2008. Cerâmica, 32 (diam.) x 15 (alt.) cm. Foto: Rafael Pillegi e Mariele Sousa. 

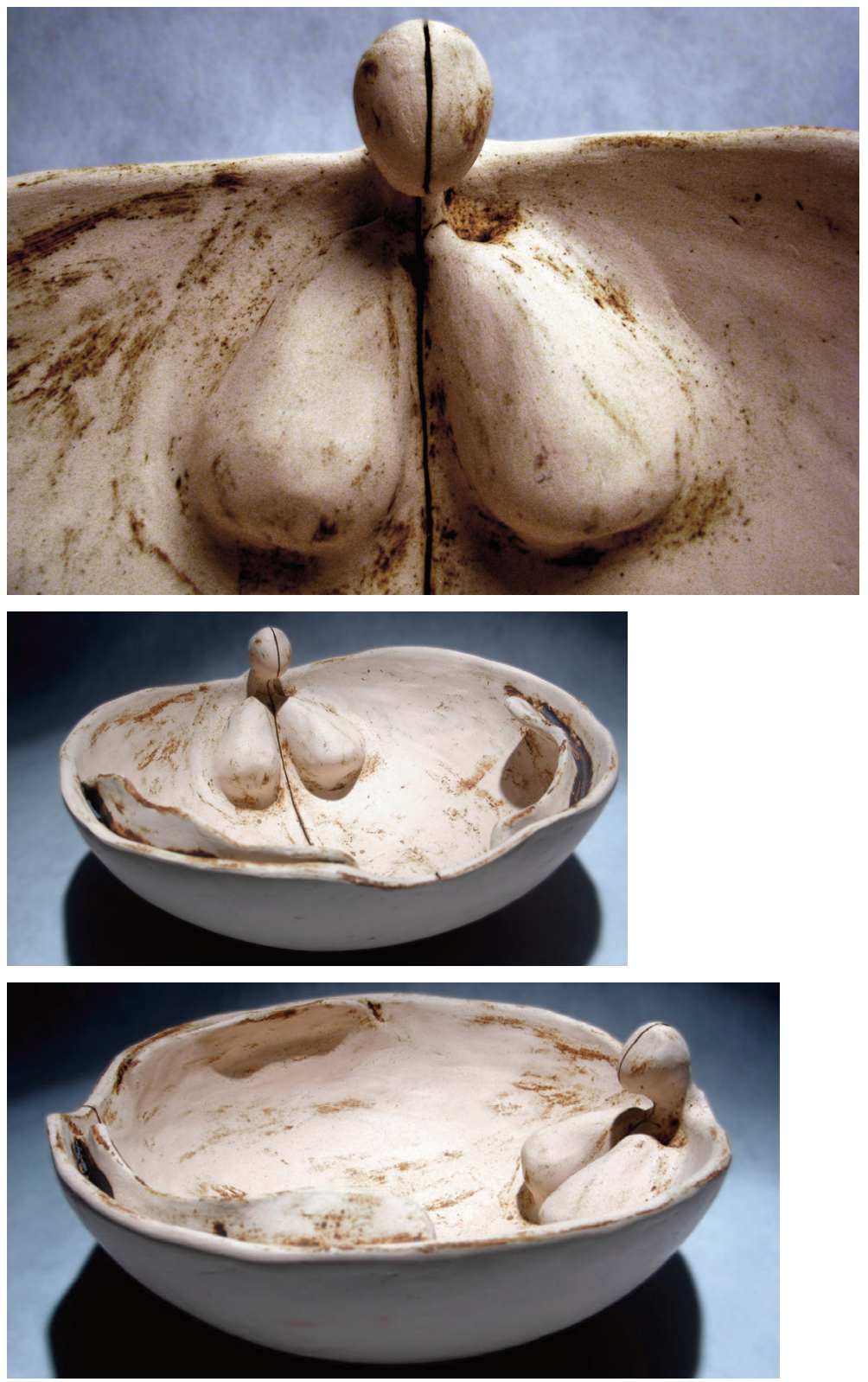

Figura 33 - Recipiente XX (série Mulheres recipientes), 2008. Cerâmica, 23 (diam.) x 13 (alt.) cm. Foto: Rafael Pillegi e Mariele Sousa. 

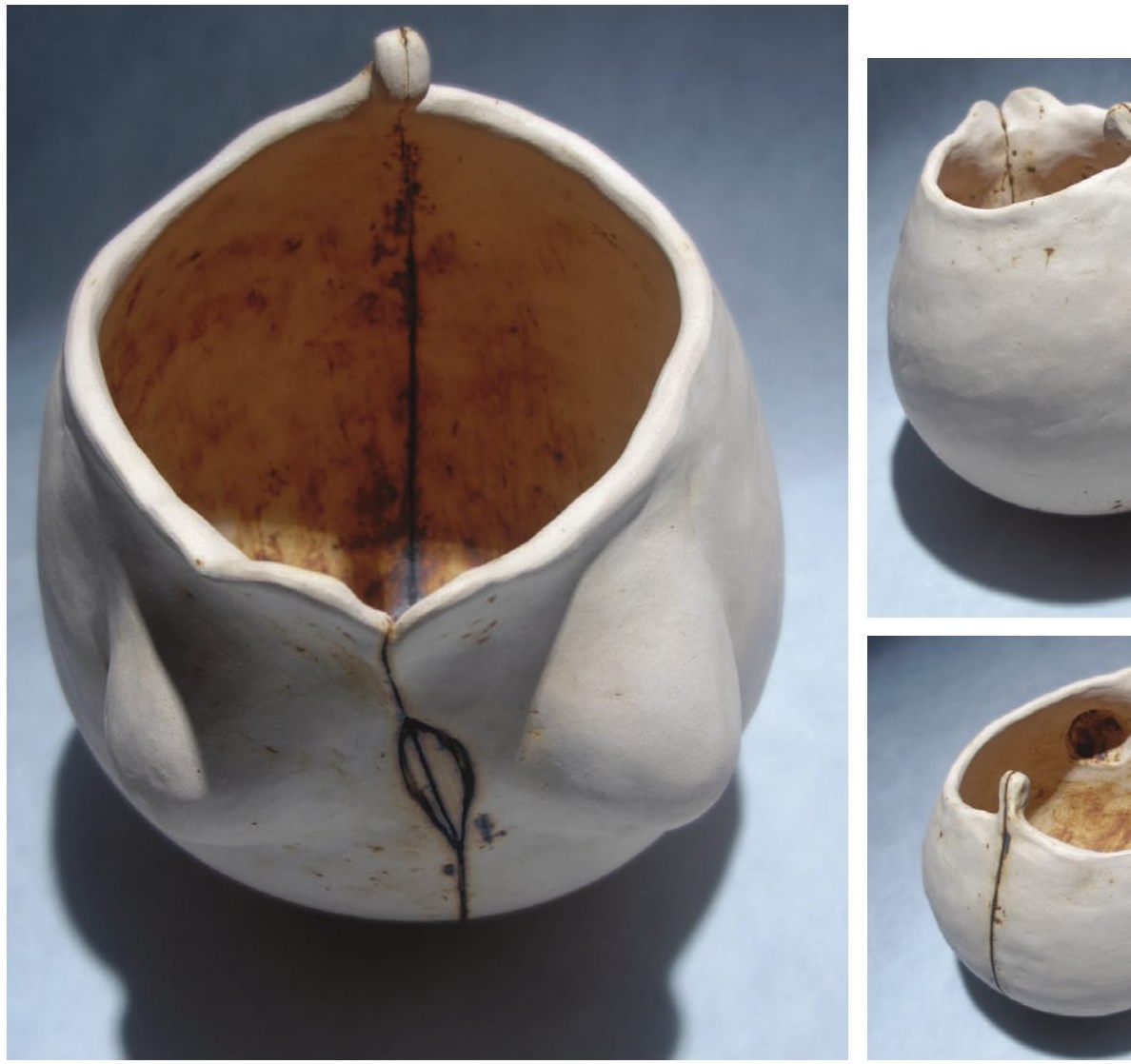

Figura 34 -Recipiente XXI (série Mulheres recipientes), 2008. Cerâmica, 21 (diam.) x 25 (alt.) cm. Foto: Rafael Pillegi e Mariele Sousa. 


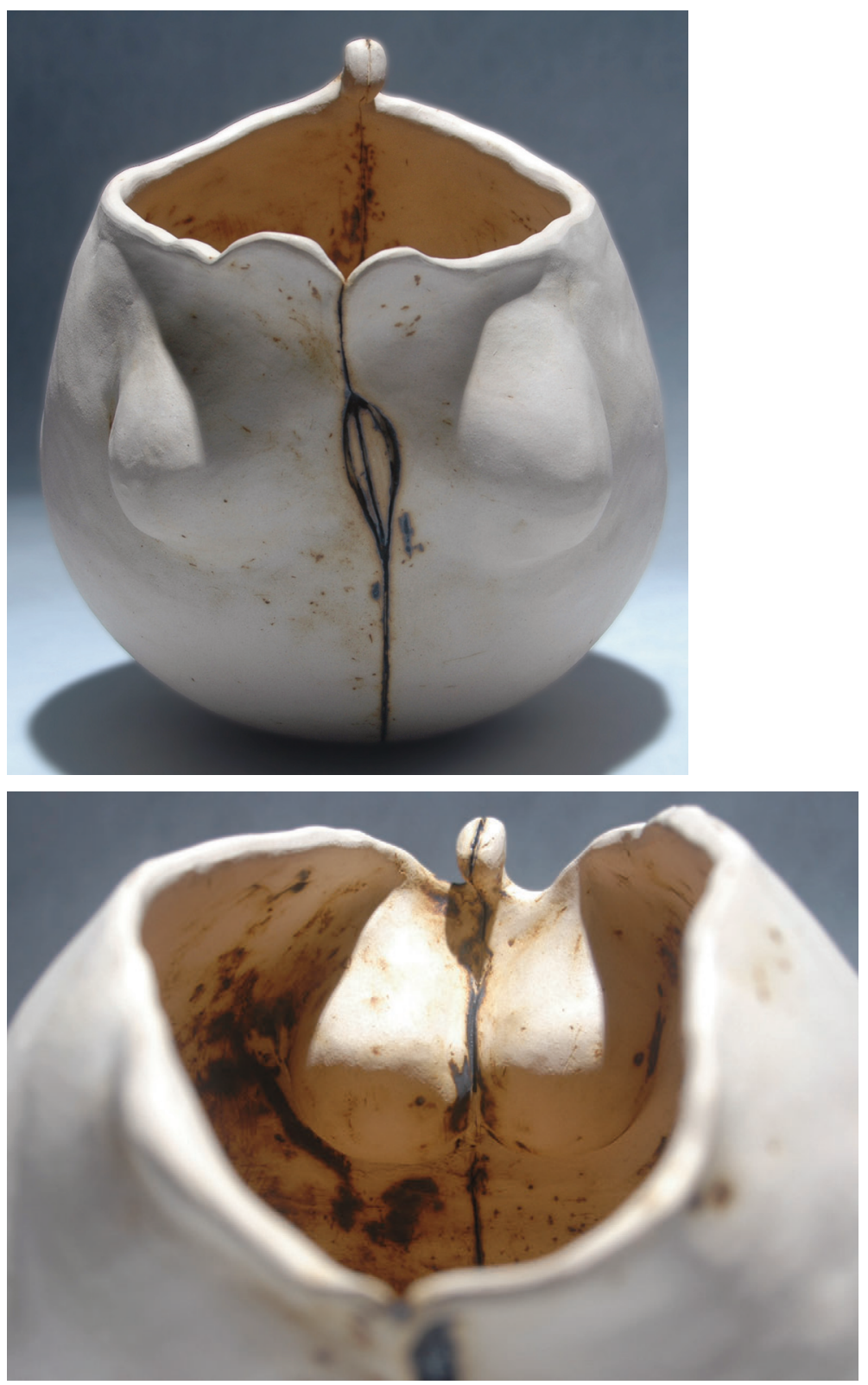



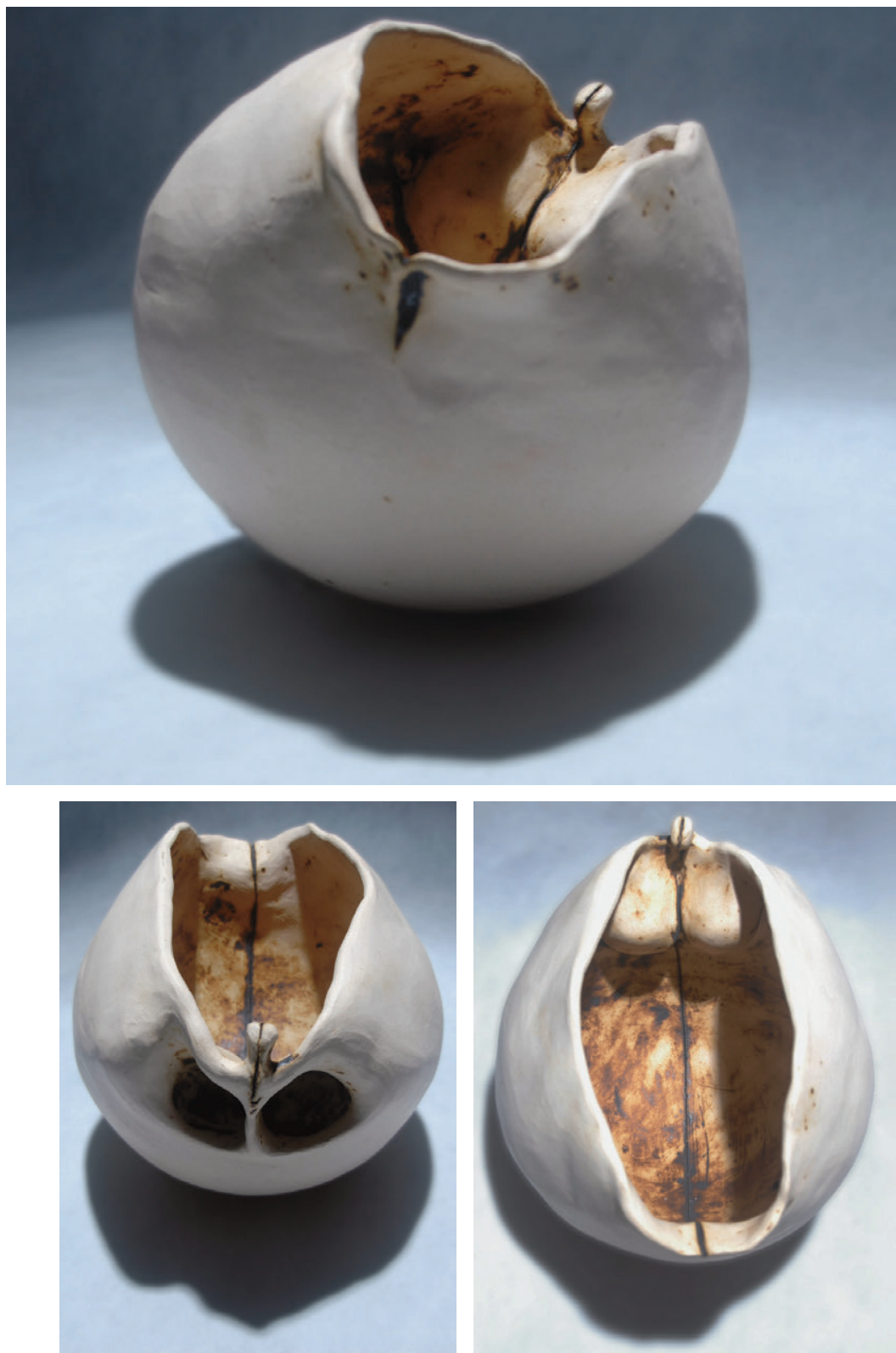

Figura 35 - Recipiente XXII (série Mulheres recipientes), 2008. Cerâmica, 22 (diam.) x 25 (alt.) cm. Foto: Rafael Pillegi e Mariele Sousa. 

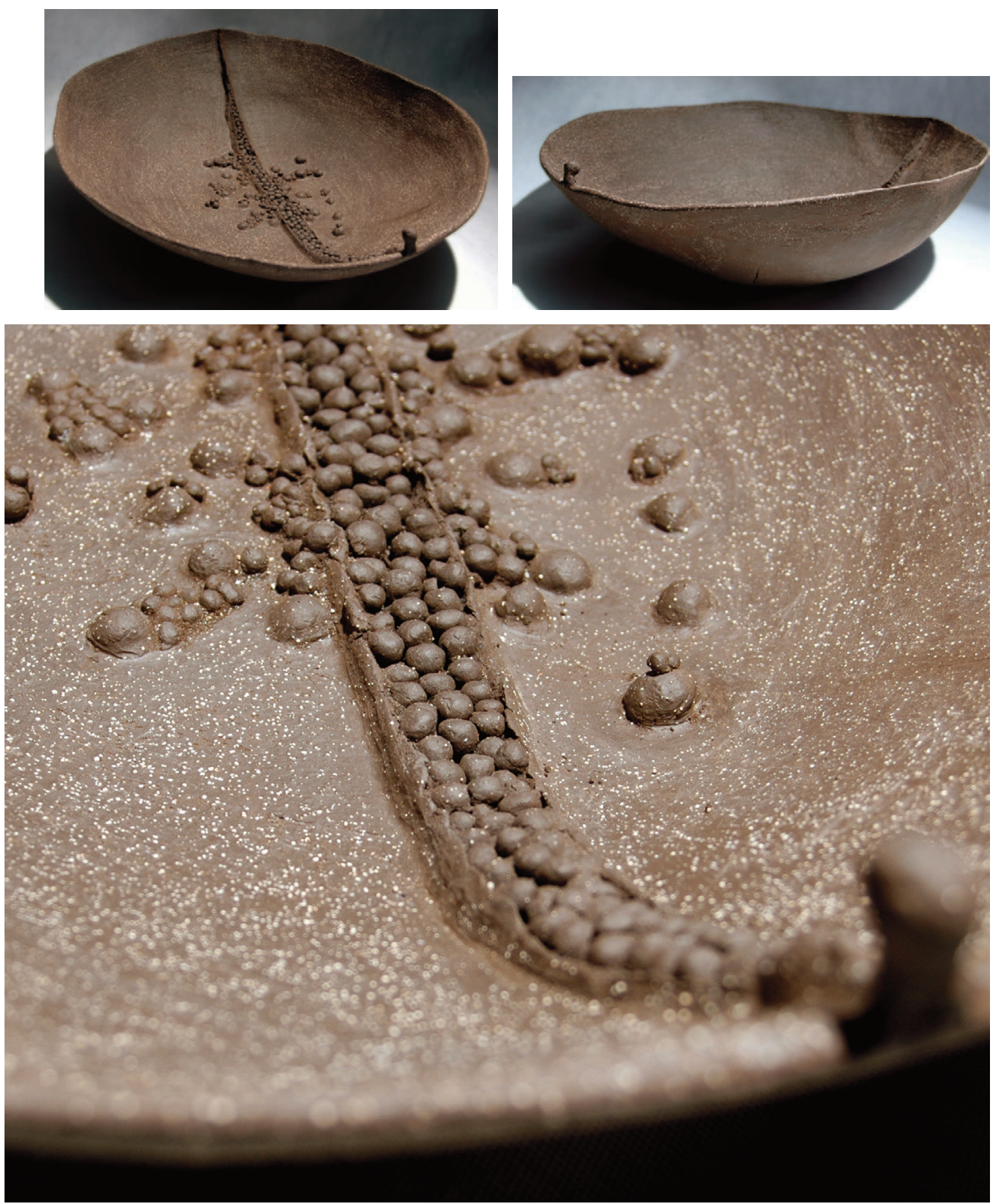

Figura 36 - Recipiente XXIII (série Mulheres recipientes), 2008. Cerâmica, 60 (diam.) x 20 (alt.) cm. Foto: Rafael Pillegi e Mariele Sousa. 

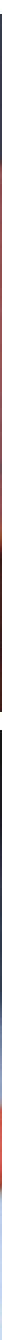

Figura 37 - Recipiente XXIV (série Mulheres recipientes 2008. Cerâmica, 65 (diam.) x 28 (alt.) cm. Foto: Rafael Pillegi e Mariele Sousa; Demétrios Daffara (detalhes). 


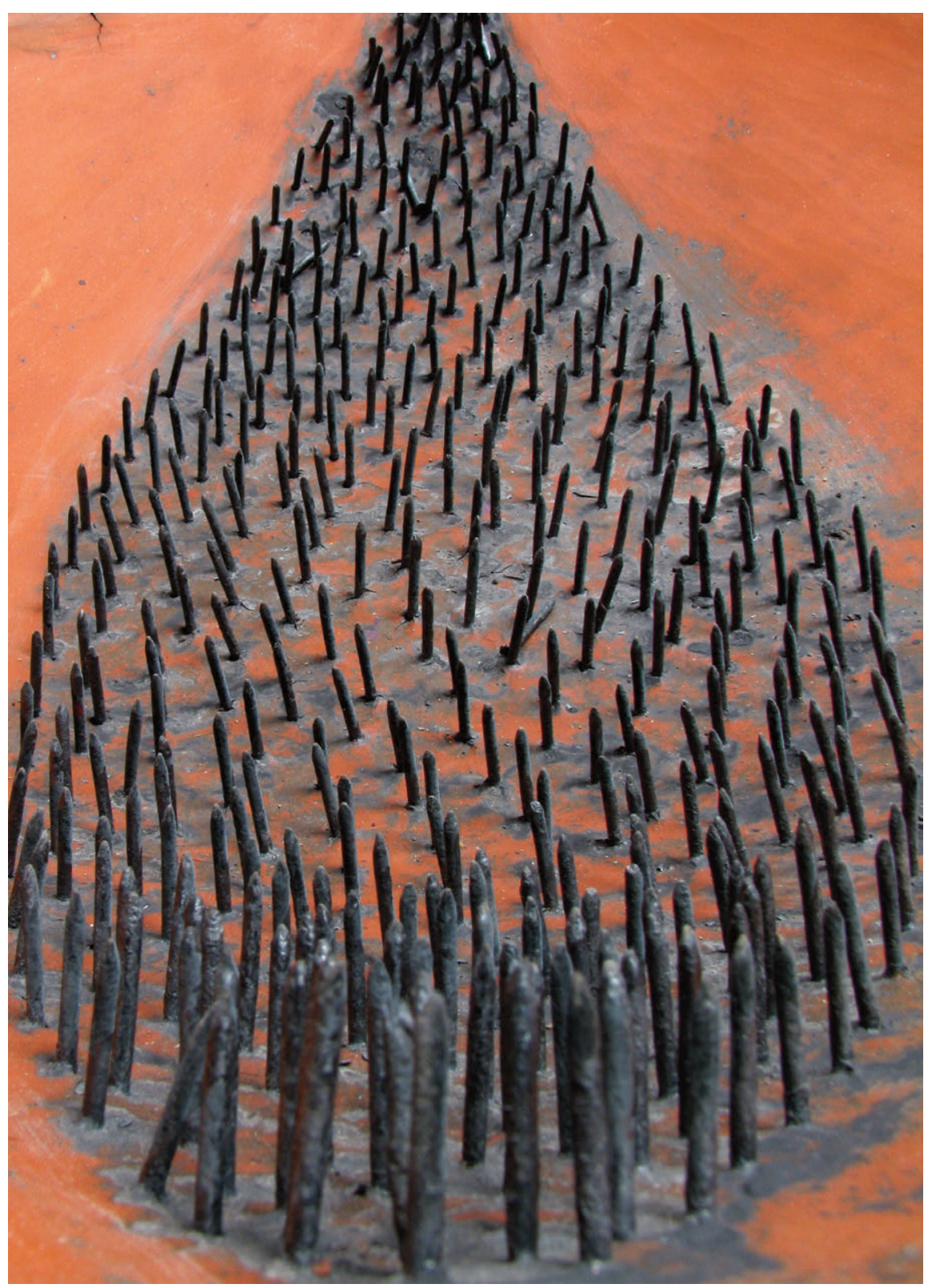




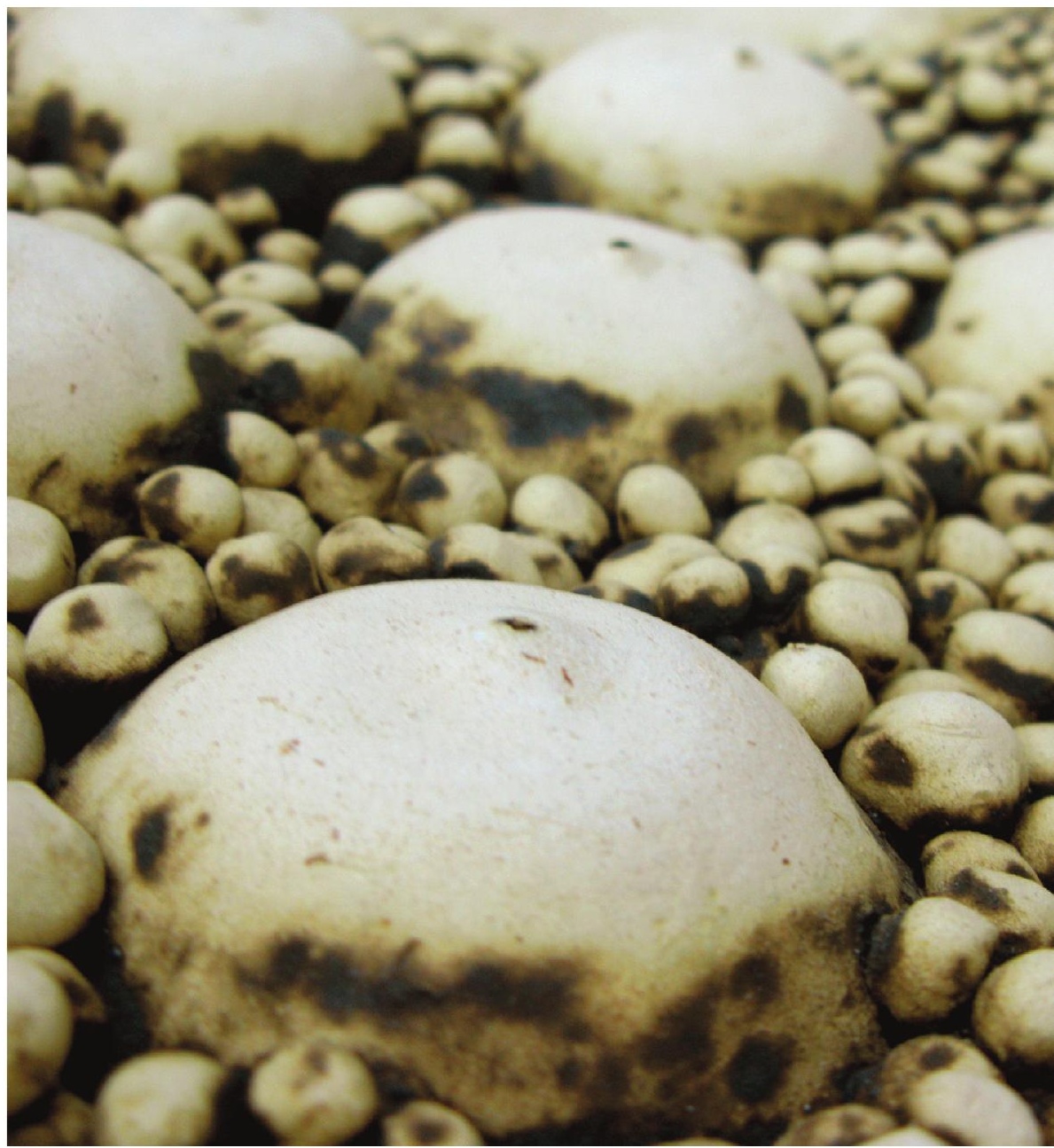

Figura 38 - Recipiente XXV (série Mulheres recipientes), 2008. Cerâmica, 65 (diam.) x 28 (alt.) cm. Foto: Rafael Pillegi e Mariele Sousa; Demétrios Daffara (detalhes). 

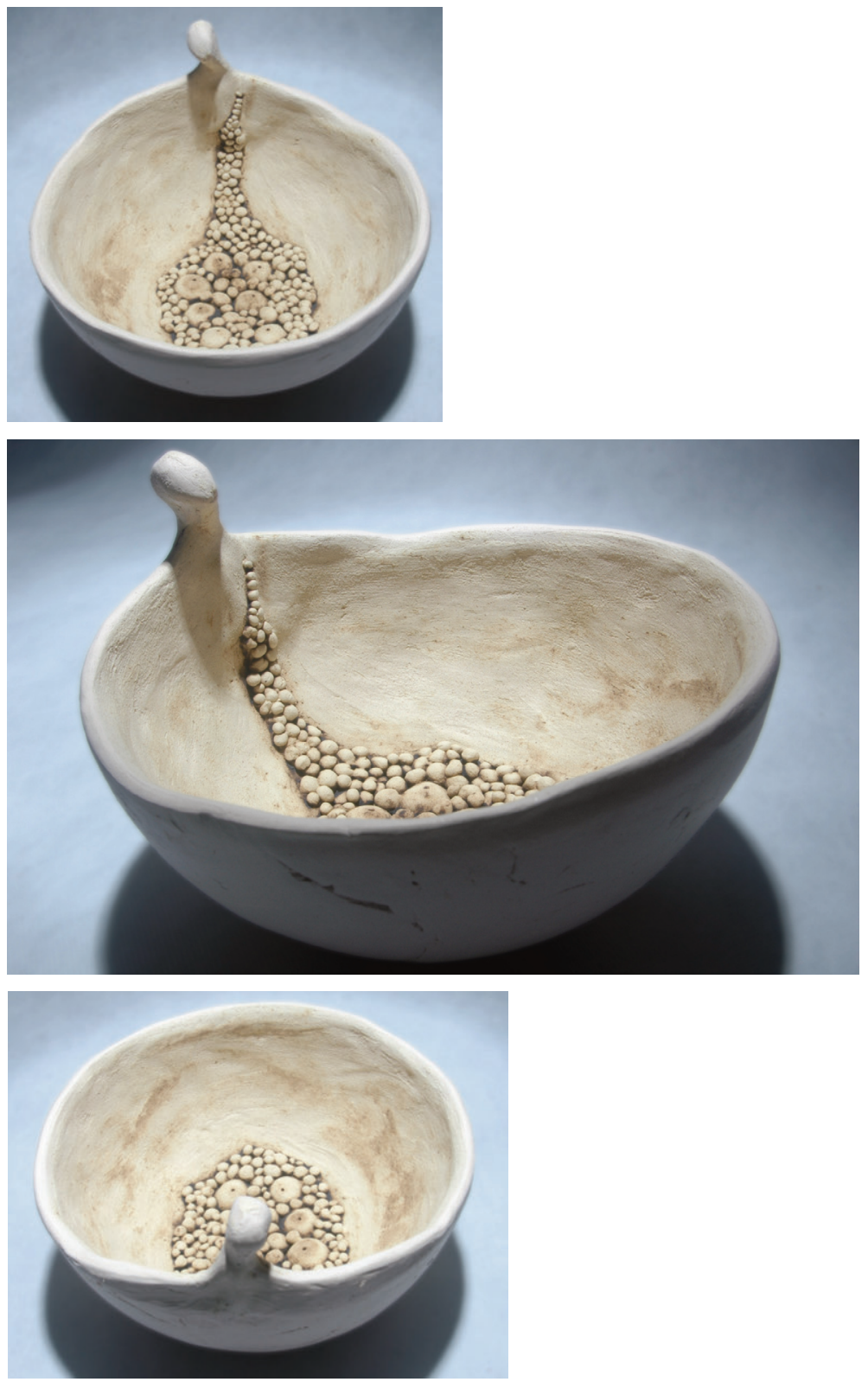

Figura 39 - Recipiente XXVI (série Mulheres recipientes), 2008. Cerâmica, 23 (diam.) x 13 (alt.) cm. Foto: Rafael Pillegi e Mariele Sousa. 

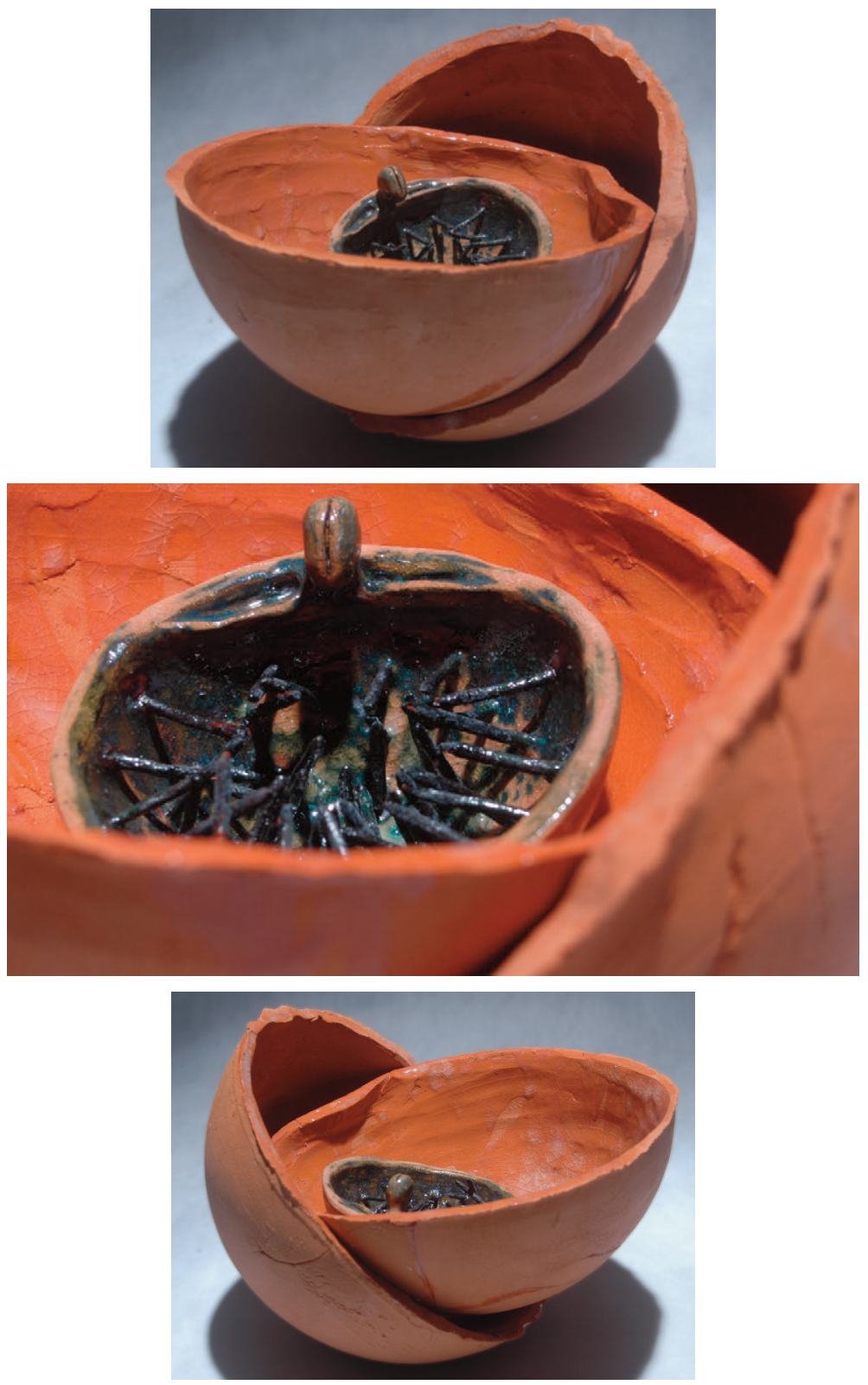

Figura 40 - Recipiente XXVIII (série Mulheres recipientes), 2008. Cerâmica, 23 (diam.) x 13 (alt.) cm. Foto: Rafael Pillegi e Mariele Sousa. 

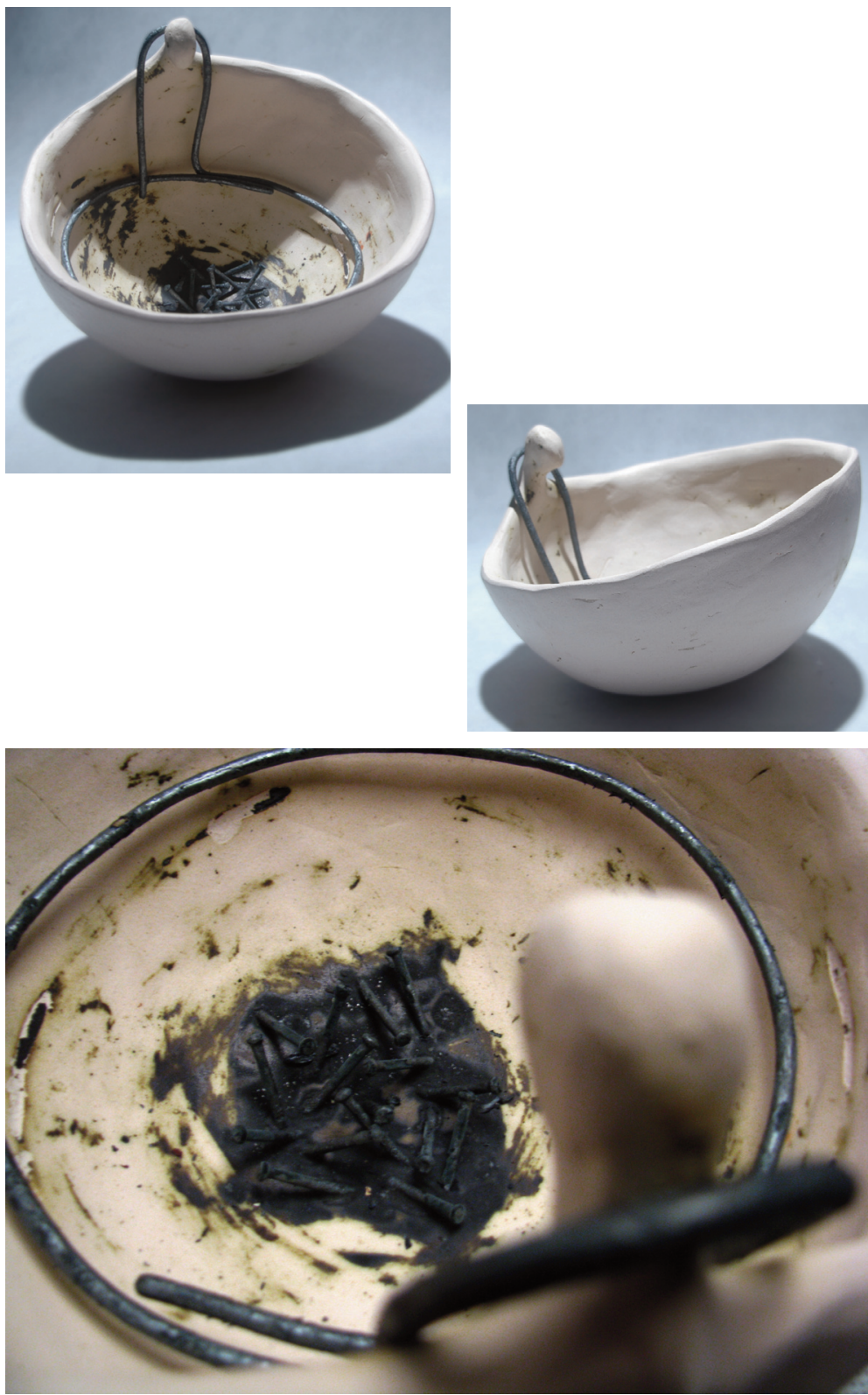

Figura 41 - Recipiente XXVII (série Mulheres recipientes), 2008. Cerâmica, 23 (diam.) x 13 (alt.) cm. Foto: Rafael Pillegi e Mariele Sousa. 

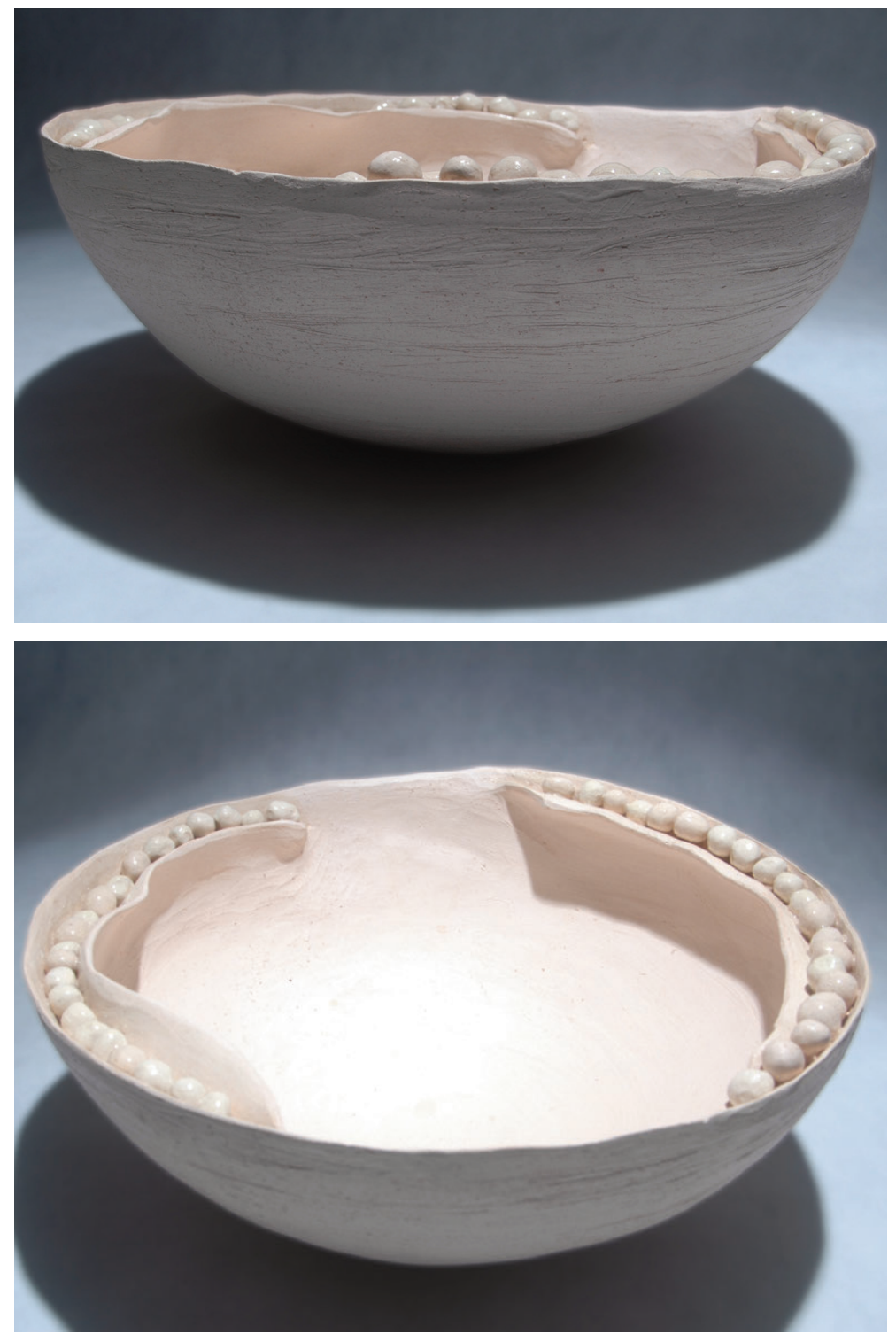

Figura 42 - Recipiente XXIX (série Mulheres recipientes), 2008. Cerâmica, 43 (diam.) x 40 (alt.) cm. Foto: Rafael Pillegi e Mariele Sousa. 

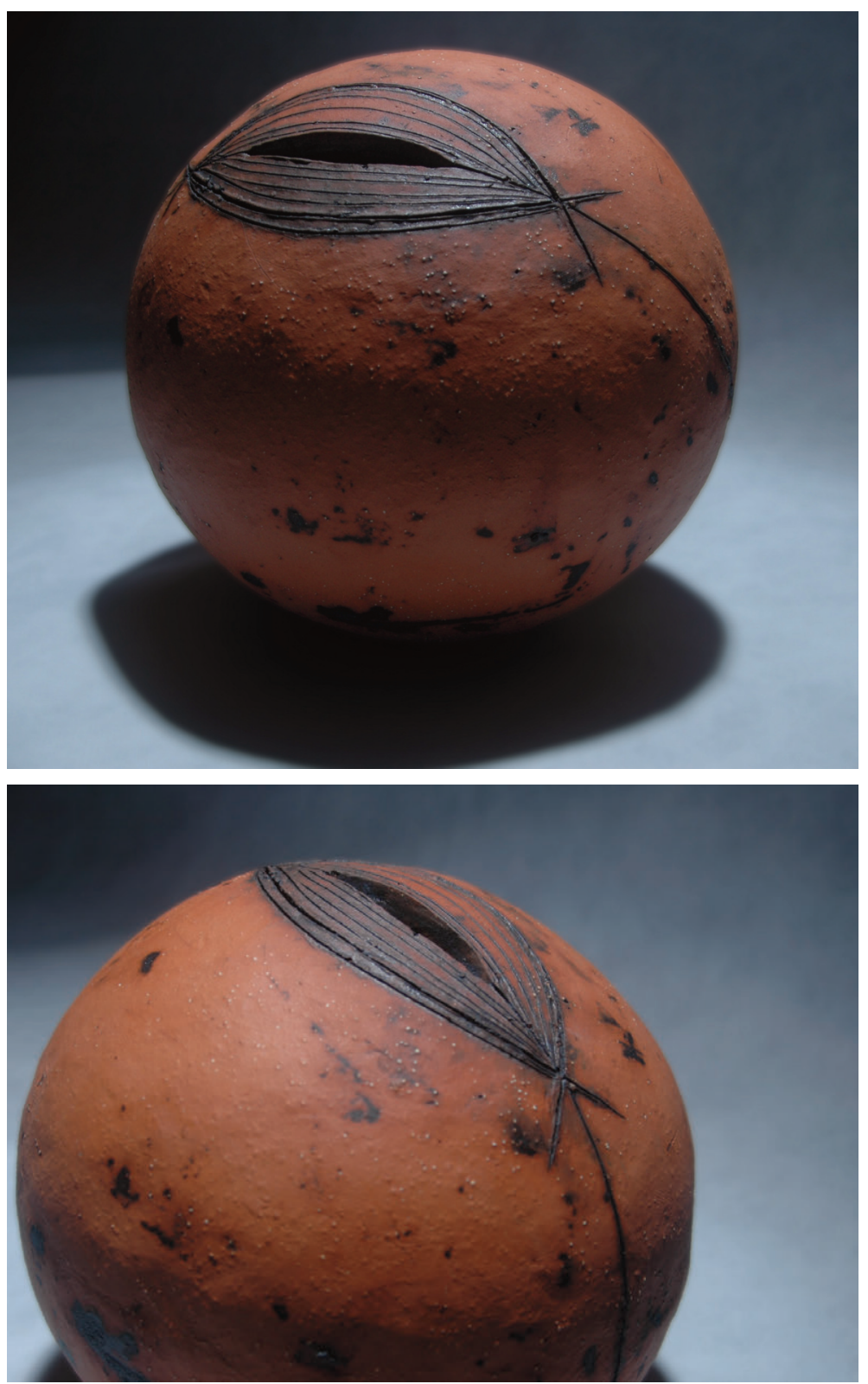

Figura 43 - Recipiente XXX (série Mulheres recipientes), 2008. Cerâmica, 43 (diam.) x 40 (alt.) cm. Foto: Flavia Leme. 


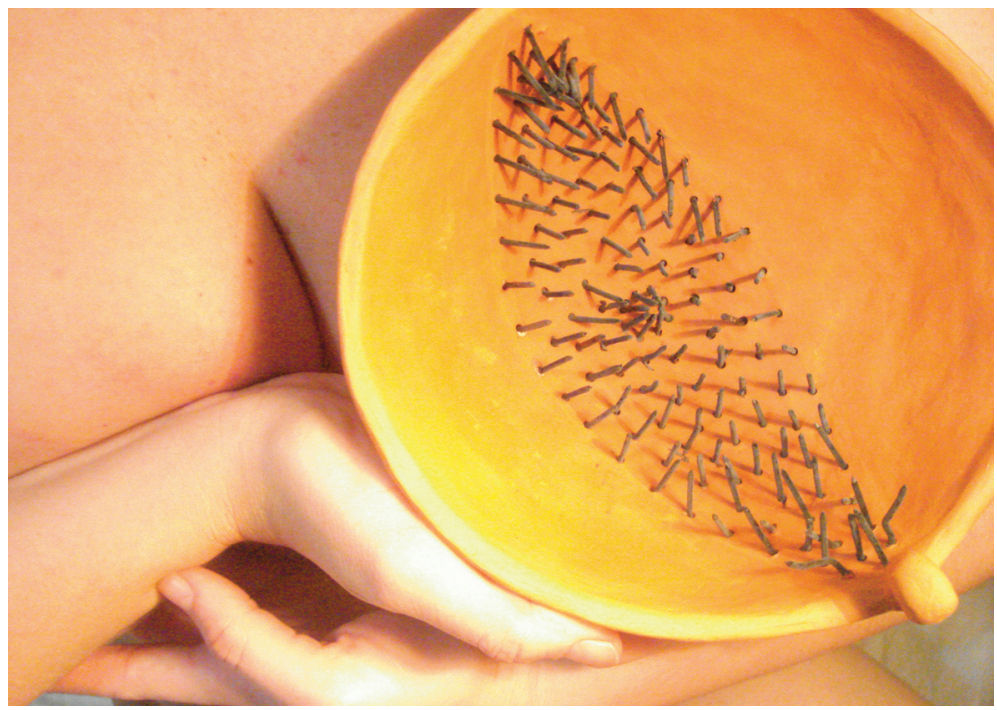

Figura 44 -fertiliza_dores I (série Mulheres recipientes), 2008. Fotografia, 10 x $15 \mathrm{~cm}$. Foto: Flavia Leme.

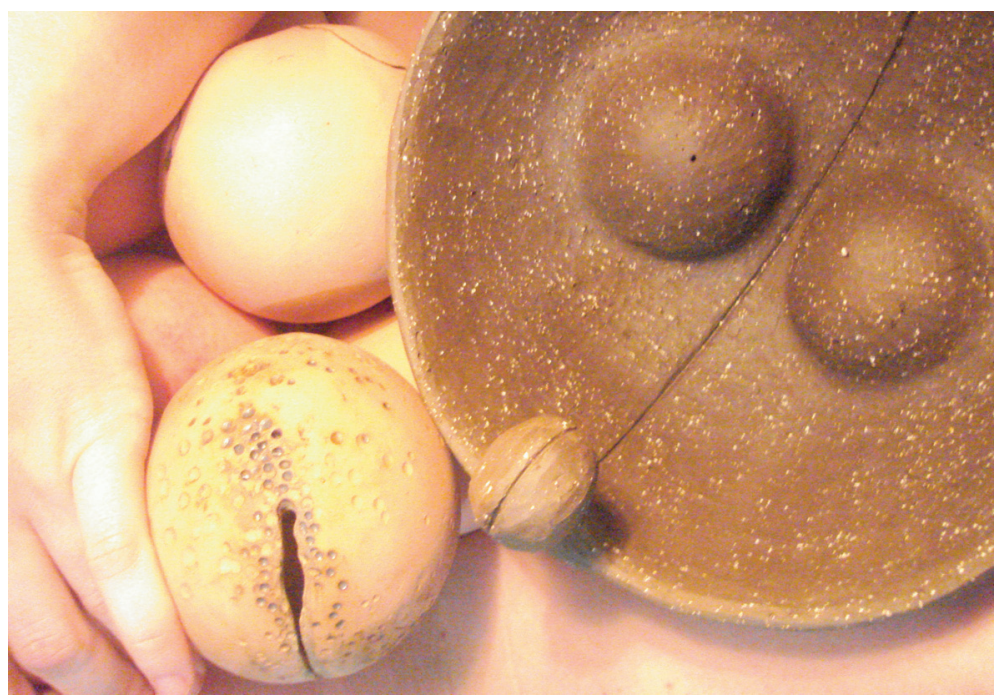

Figura 45 -fertiliza_dores II (série Mulheres recipientes), 2008. Fotografia, 10 x $15 \mathrm{~cm}$. Foto: Flavia Leme. 


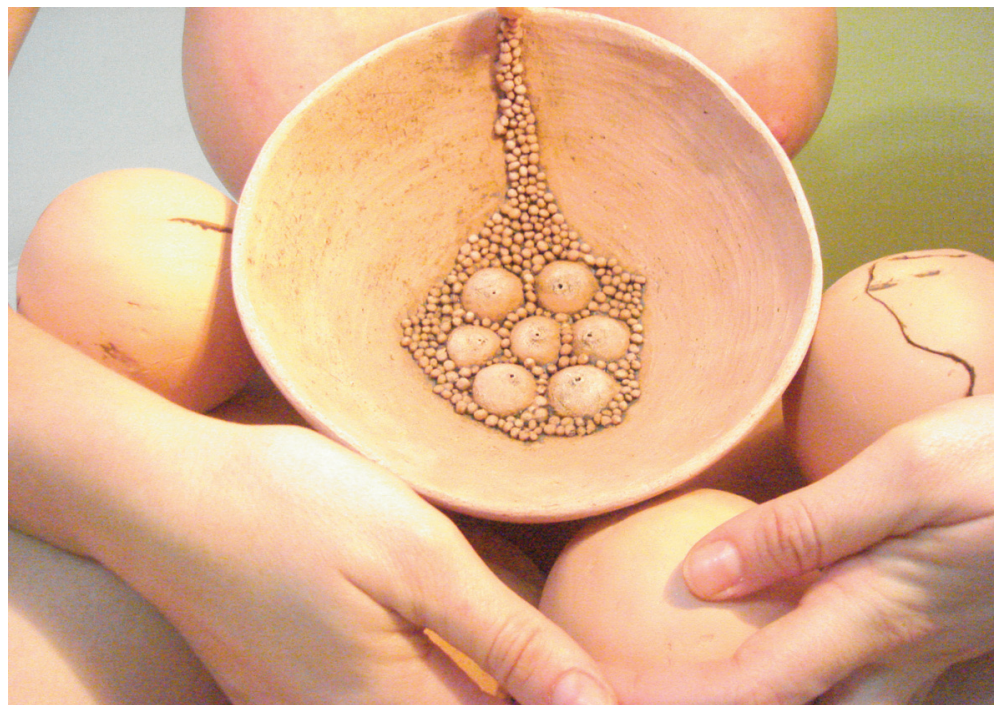

Figura 46 -fertiliza_dores III (série Mulheres recipientes), 2008. Fotografia, 10 x $15 \mathrm{~cm}$. Foto: Flavia Leme.

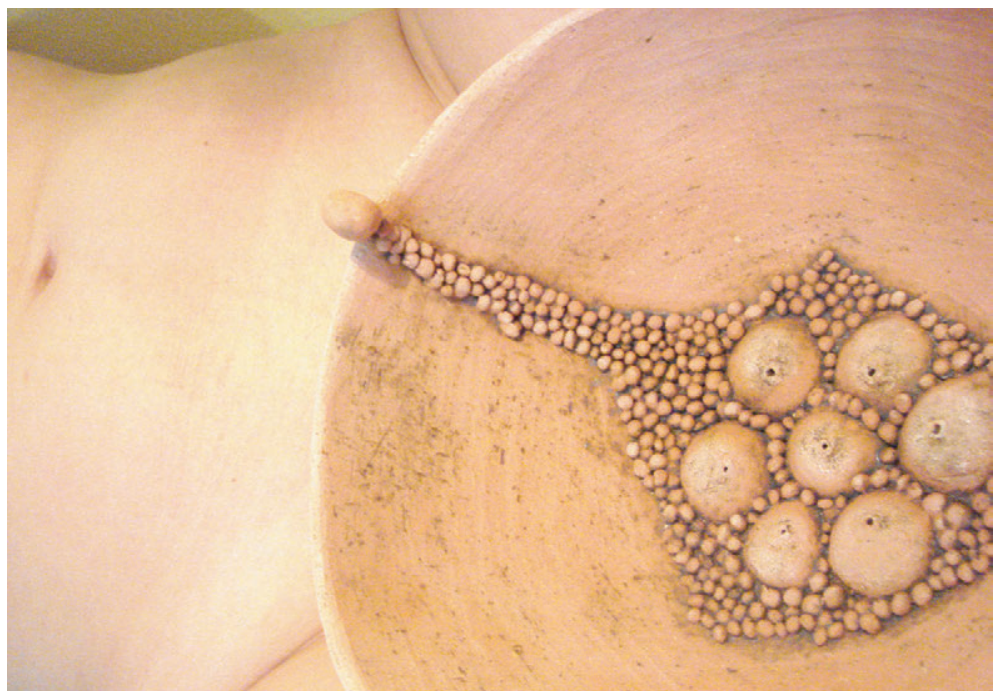

Figura 47 -fertiliza_dores IV (série Mulheres recipientes), 2008. Fotografia, 10 x $15 \mathrm{~cm}$. Foto: Flavia Leme. 


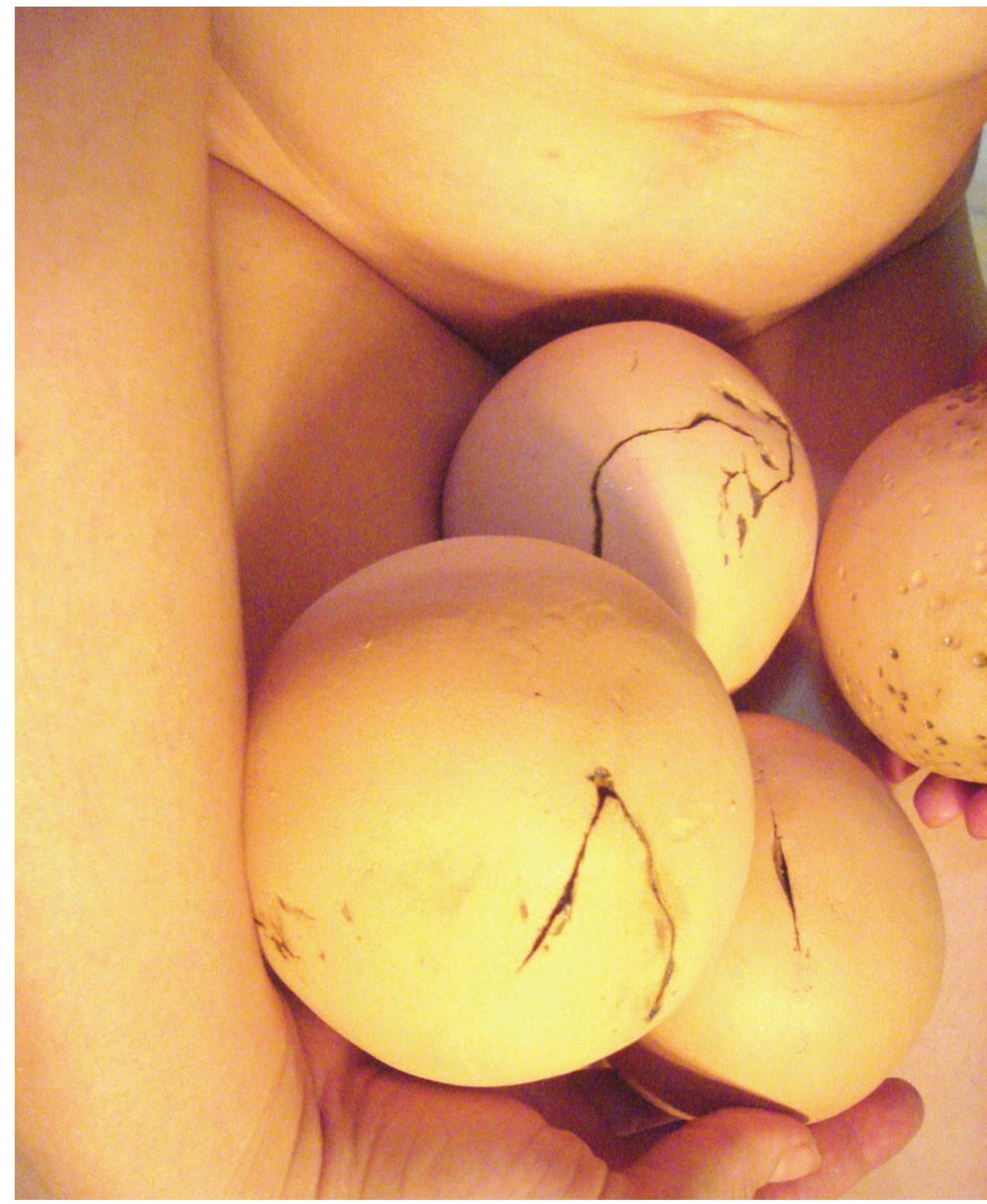

Figura 48 -fertiliza_dores $V$ (série Mulheres recipientes), 2008. Fotografia, 10 x $15 \mathrm{~cm}$. Foto: Flavia Leme. 


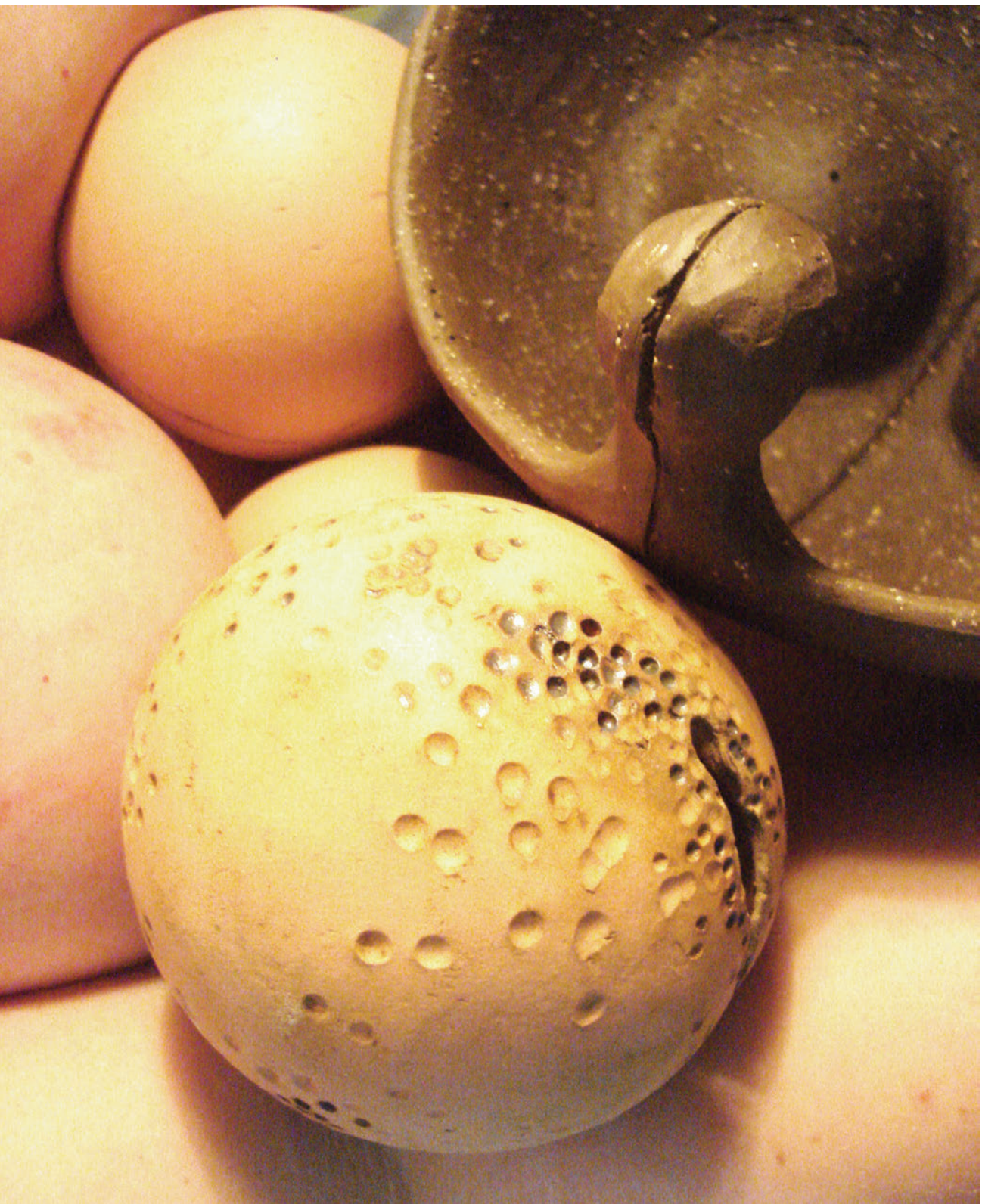

Figura 49 -fertiliza_dores VI (série Mulheres recipientes), 2008. Fotografia, 10 x $15 \mathrm{~cm}$. Foto: Flavia Leme. 


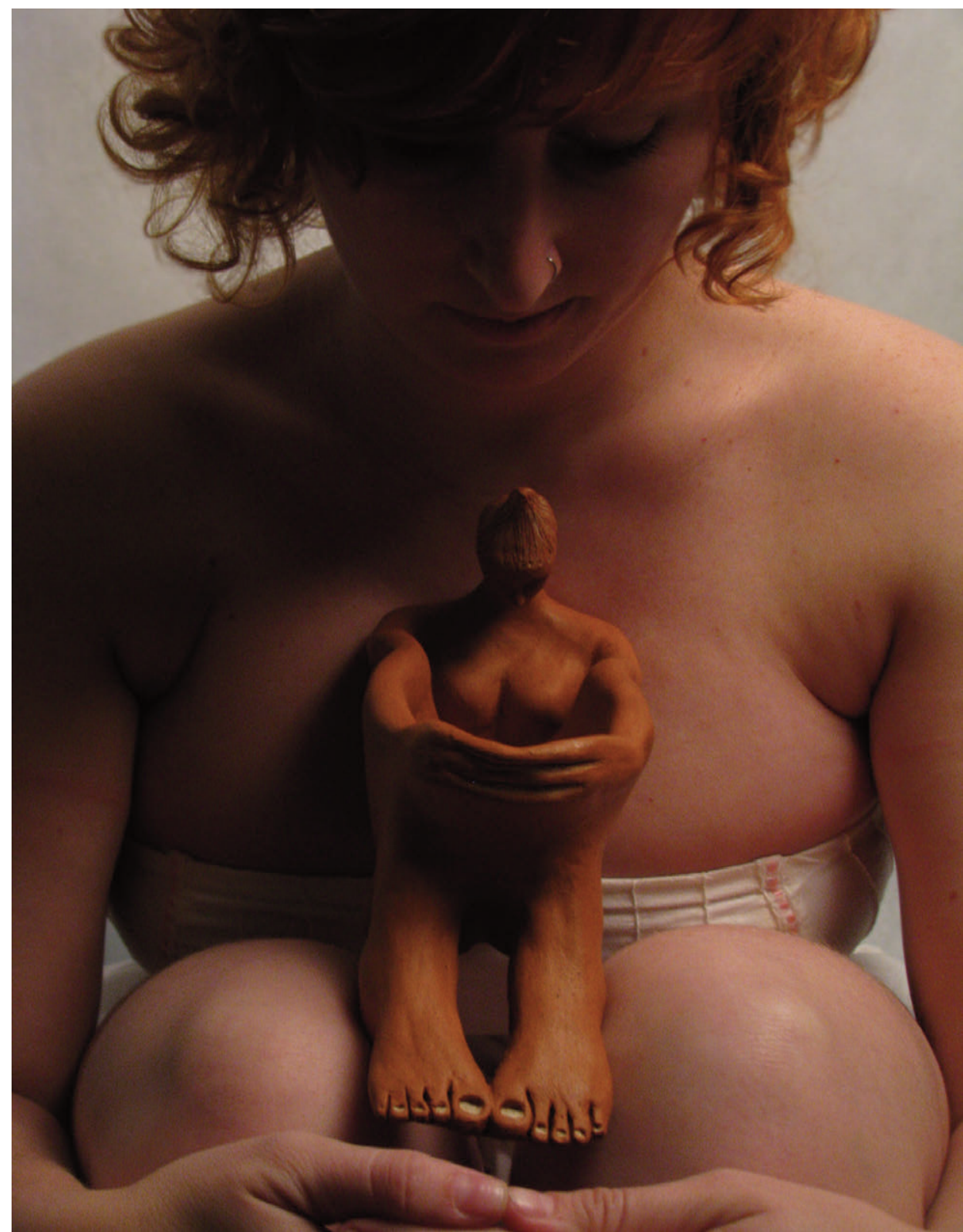

Figura 50 -fertiliza_dores VII (série Mulheres recipientes), 2008. Fotografia, 16,5 x $22 \mathrm{~cm}$. Foto: Rafael Pillegi e Mariele Sousa. 


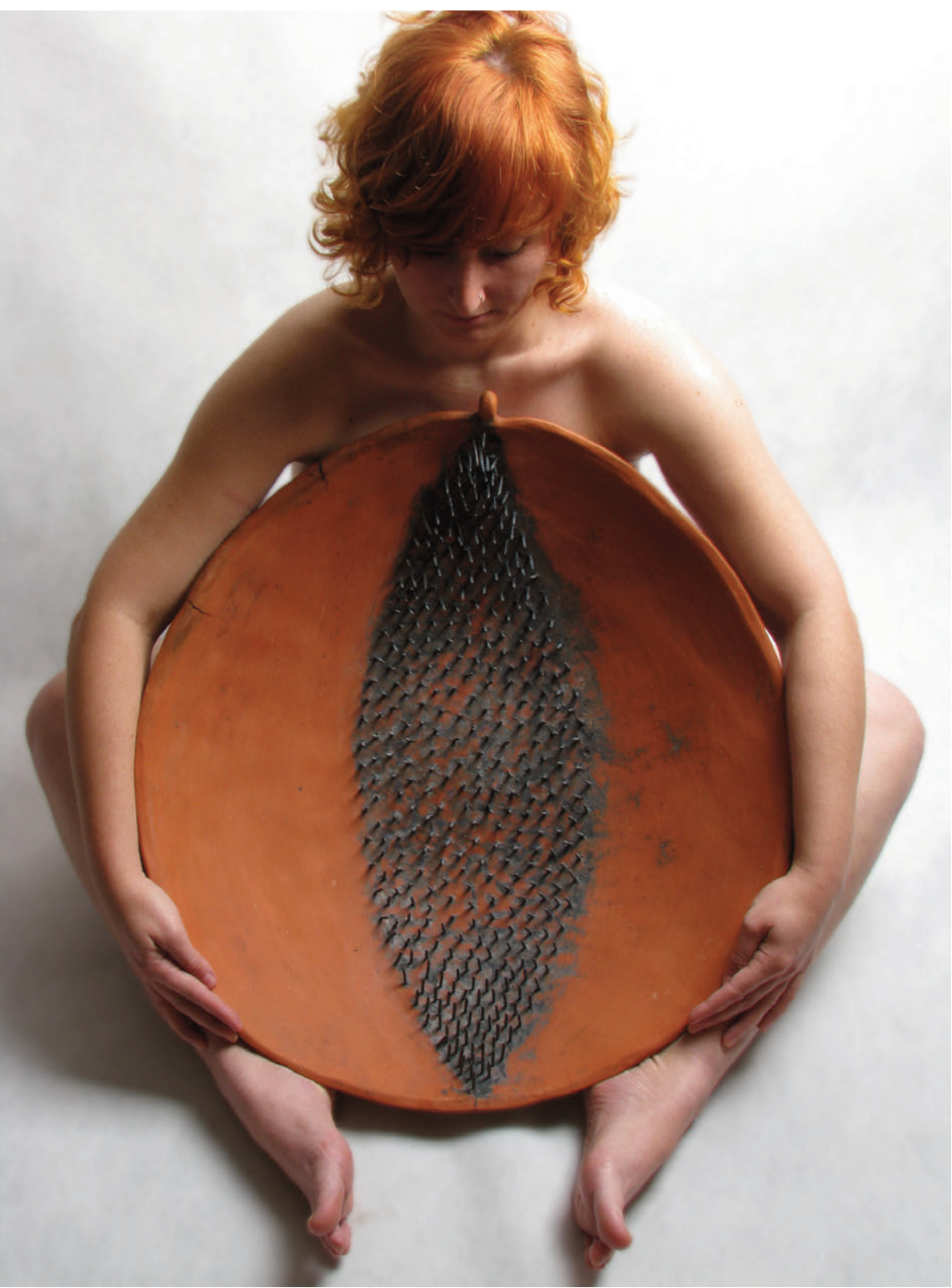

Figura 51 -Flavia Leme.fertiliza_dores VIII (série Mulheres recipientes), 2008. Fotografia, 16,5 x 22 cm. Foto: Rafael Pillegi e Mariele Sousa. 


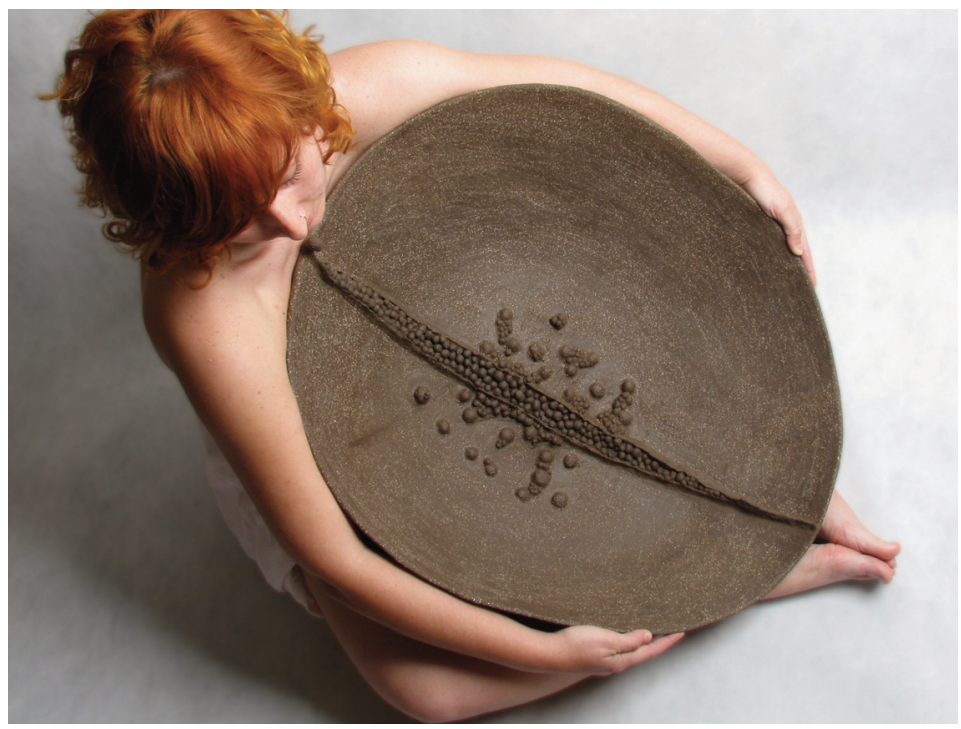

Figura 52 -fertiliza_dores IX (série Mulheres recipientes), 2008. Fotografia, 16,5 x $22 \mathrm{~cm}$. Foto: Rafael Pillegi e Mariele Sousa.

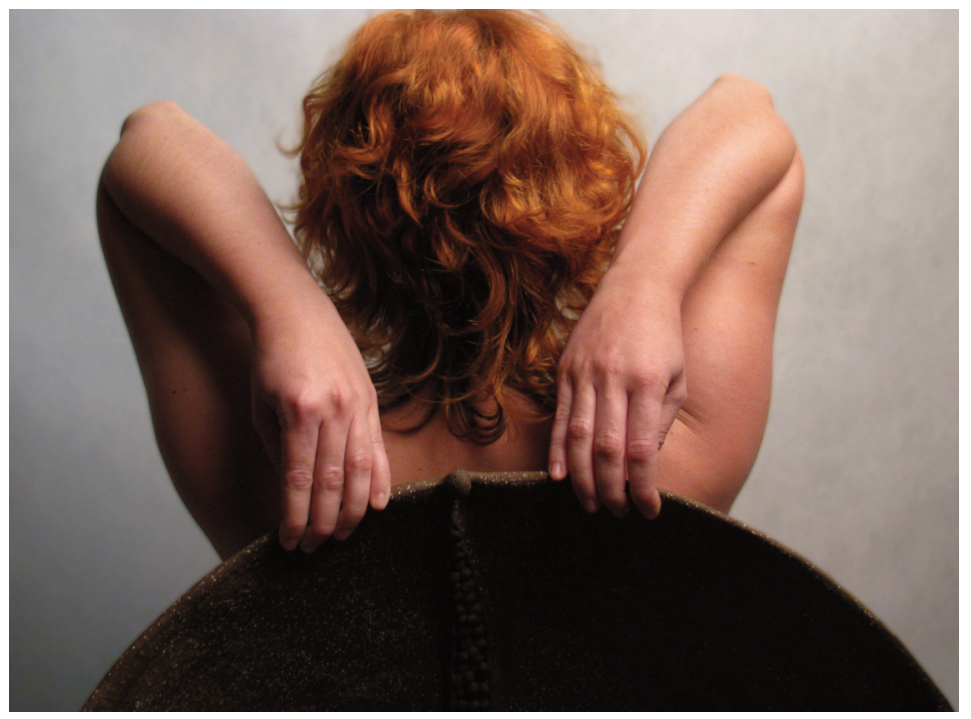

Figura 53 -fertiliza_dores $X$ (série Mulheres recipientes), 2008. Fotografia, 16 x $22 \mathrm{~cm}$. Foto: Rafael Pillegi e Mariele Sousa. 


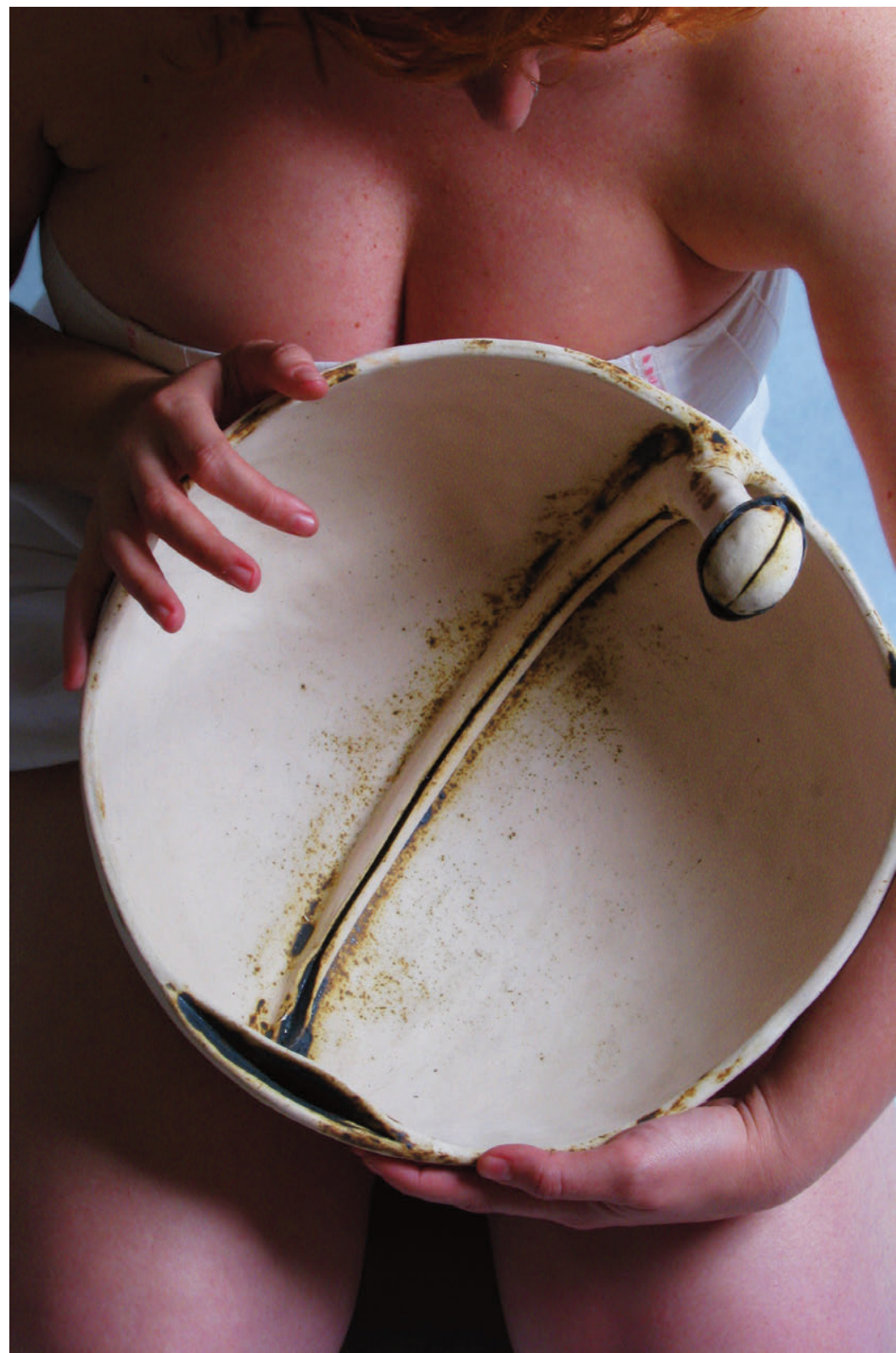

Figura 55 -fertiliza_dores XII (série Mulheres recipientes), 2008. Fotografia, 15,5 x $20 \mathrm{~cm}$. Foto: Rafael Pillegi e Mariele Sousa. 


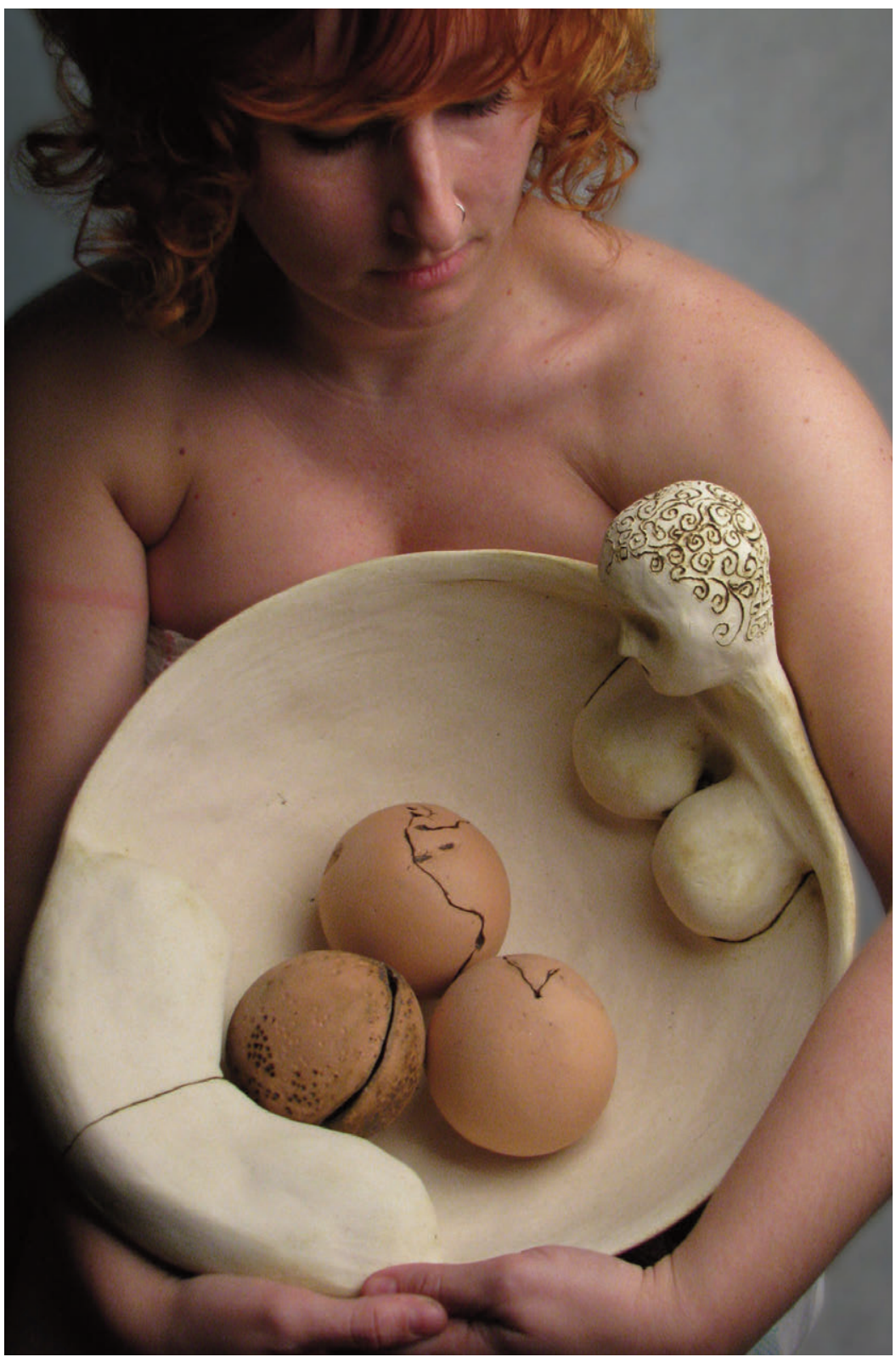

Figura 56-Flavia Leme.fertiliza_dores XIII (série Mulheres recipientes), 2008. Fotografia, 15 x 20 cm. Foto: Rafael Pillegi e Mariele Sousa. 


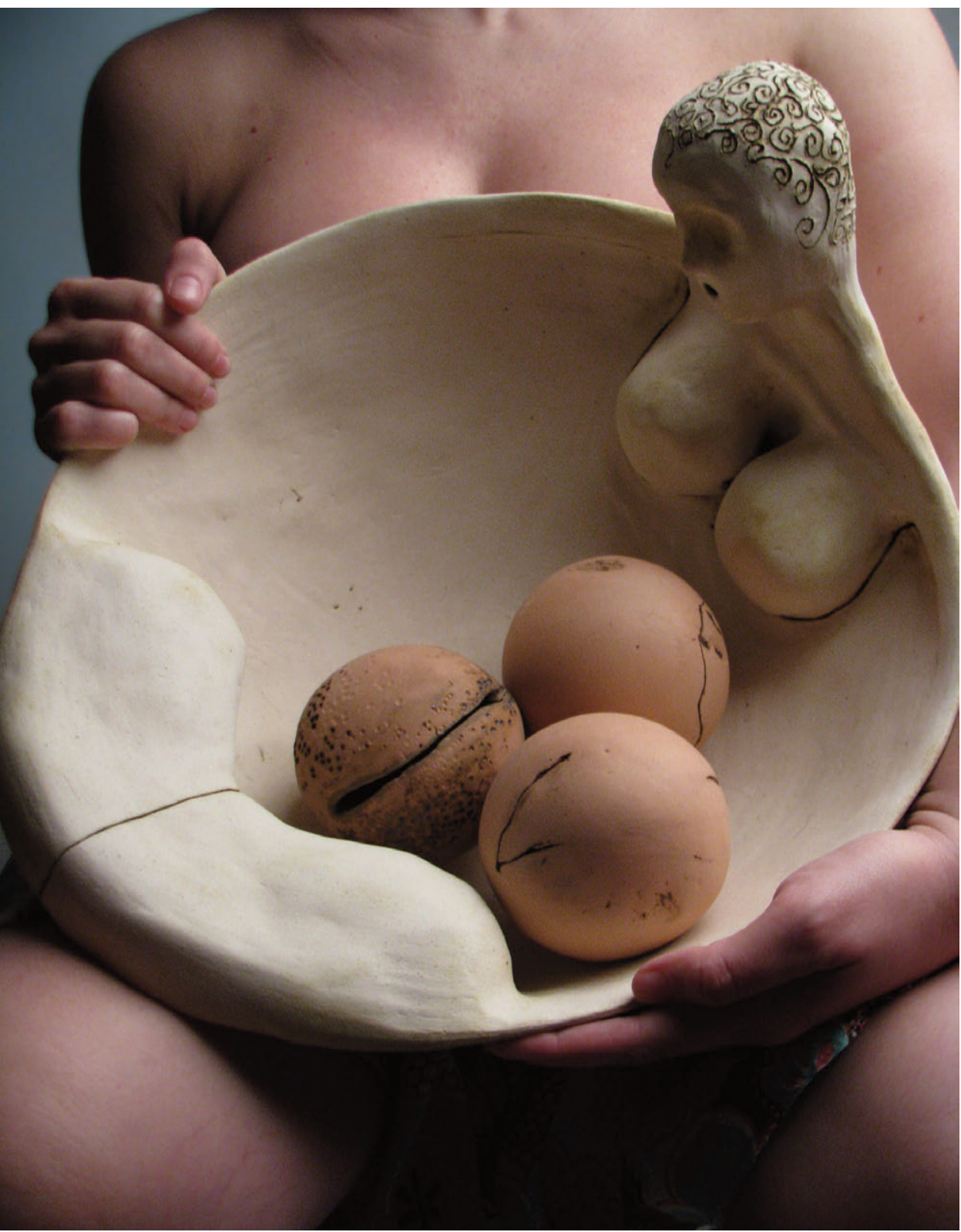

Figura 57 -fertiliza_dores XIV (série Mulheres recipientes), 2008. Fotografia, 15,5 x $20 \mathrm{~cm}$. Foto: Rafael Pillegi e Mariele Sousa. 

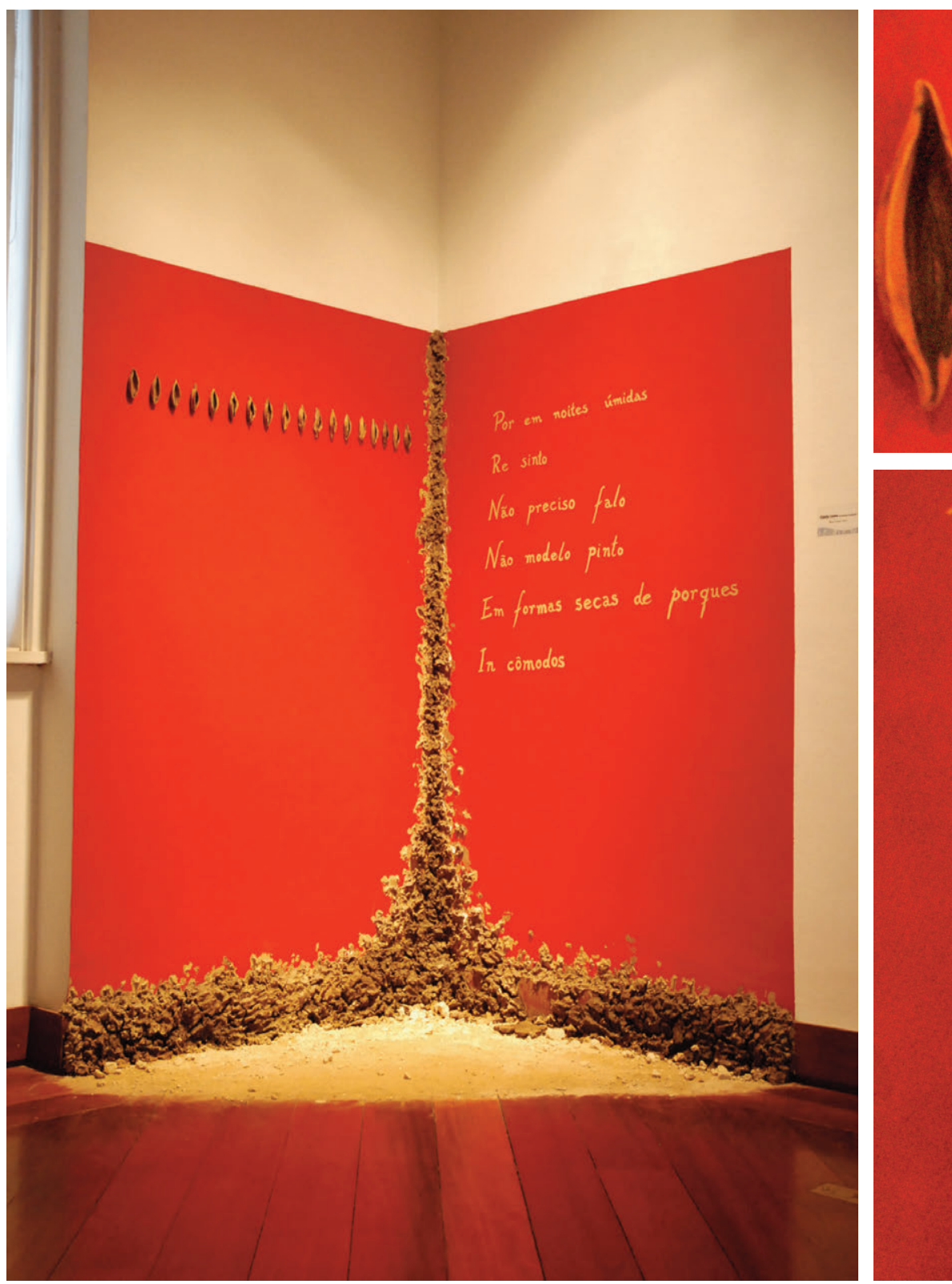

Figura 58 - encarna_dores (série Mulheres recipientes), 2008. Instalação (cerâmica, argila em pó e barbotina), dimensões variadas. II Salão Nacional de Cerâmica (PR). Foto: Flavia Leme. 
MULHERES RECIPIENTES

177

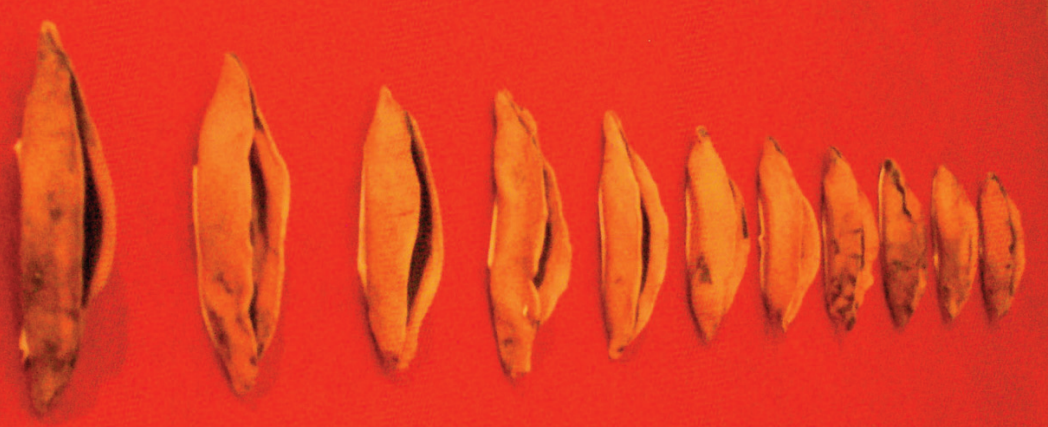

Por em noites úmidas

Re sinto

Não preciso falo

Não modelo pinto

Em formas secas de porques

In comodos 



\section{Considerações finaIS}

"A palavra alma é uma palavra imortal.

Em certos poemas ela é indelével. Uma palavra de alento."

Gaston Bachelard

Mulheres recipientes, uma pesquisa prática em cerâmica, significou uma possibilidade a mais para a compreensão do universo artístico feminino, a alma do texto. Neste livro entrelaçaram-se variados caminhos trilhados por artistas que possuíam um mesmo ponto de intersecção: a busca do universo feminino nas artes visuais, sob o ponto de vista da mulher na nossa sociedade ocidental. A intenção aqui foi demonstrar que a série Mulheres recipientes está inserida num contexto artístico contemporâneo, por se tratar de uma poética recorrente na produção de algumas artistas da atualidade.

A despeito da série Mulheres recipientes tratar de obras feitas em cerâmica, um material que traz junto de si uma forte carga conceitual, por ser utilizado há milhares de anos para fins diversos, que não apenas o artesanal utilitário ou decorativo, as peças são, intencionalmente, feitas para serem apreciadas como objetos artísticos. Objetos que trazem em si uma forte intenção de situar o papel da mulher na arte e na vida contemporânea. Mas o que seriam as 
Mulheres recipientes? O que querem esses objetos? O que eu, como artista, pretendo com esse tipo de obra e com esse tipo de material? Todos sabemos que o material fala muito sobre a obra e que a própria obra deve falar por si mesma - caso contrário, o artista trabalharia através da linguagem escrita e não da visual. A cerâmica é por essência um material orgânico, é a argila queimada. É, pois, um material que teve origem no "ventre da terra" e, seguindo um modo de pensar de nossos ancestrais do Paleolítico, o barro foi gerado pela Mãe Terra, a Pachamama. A argila é, também, para muitos povos indígenas, um material típico do universo feminino; o pote de barro é uma mulher. Além disso, é um dos mais plásticos materiais para se modelar por suas características físicas. A argila é, portanto, um suporte intimamente ligado ao universo feminino.

Ao iniciar essa pesquisa, minha intenção era mostrar que minha proposta está ligada à arte contemporânea. Mesmo que a argila seja um material pouco usado como suporte final atualmente, entre as artistas (es)colhidas, Celeida Tostes e Judy Chicago trabalhavam com cerâmica. Encontrei-me, também neste percurso, com todas as outras artistas germinadoras. Descobri afinidades poéticas entre minha cerâmica e a obras dessas artistas e, ao me reunir com elas, pude fazer de forma mais concisa a ligação entre a minha pesquisa poética e artística, a série Mulheres recipientes, com a obra dessas artistas.

Assim como Frida Kahlo, mostro-me também em minhas obras. Mas, diferente dela, não me elegi como modelo literal, pois não faço autorretrato. Meu ponto de vista é o de mostrar o corpo feminino como um grande ventre (recipiente). Frida Kahlo pintou muito de seu sofrimento em vida, representando-o de modo forte, bravo, estóico, mostrando o quanto os traços profundos dessa dor tinham atingido seu corpo e seu espírito. Eu, ao contrário, não expresso minhas angústias através do corpo ferido, mas do potencial que ainda há nele.

Louise Bourgeois foi uma das artistas que mais marcou minha trajetória artística. Sua poética tão rica em simbologias e interpretações, a liberdade no uso de materiais diversos para se expressar apenas através da escultura, da linguagem tridimensional, tudo isso serviu como fonte de inspiração criadora para mim. Suas esculturas 
privilegiam as formas que insinuam o corpo de mulher, as formas que lembram entranhas, as aranhas enormes com suas bolsas cheias de ovos, a casa, o quarto, a espera, a intimidade. Todas essas sugestões simbólicas me motivam e é o que tento transmitir nas minhas esculturas - o feminino em amplo espectro. As questões do universo feminino se aliam e se fundem com as colocações transformadas em objetos. O feminino transposto na escultura.

Grande evocadora do poder das deusas votivas, Celeida Tostes celebrava a força da Pachamama. Em suas obras, a artista Celeida de Barro, assim como eu, mantinha a argila como o principal suporte para desenvolver suas obras. $\mathrm{O}$ feminino estava moldado em seus dez mil ovos, nas centenas de vênus, na sua performance em que se vestiu de barro, entrou no ventre da terra. Transmutou-se em outra vida ao se encolher dentro de um pote - enterrou-se como em uma urna funerária. $\mathrm{O}$ ventre, a reprodução (ou a repetição) está no bojo de nossas produções artísticas.

Uma outra maneira encontrada de expressar o feminino através da escultura são as graciosas Nanas, de Niki de Saint Phalle, com suas volumosas formas celebrando a fertilidade no corpo da mulher em uma explosão de cores e linhas. As Nanas foram para mim uma descoberta lúdica e alegre do poder do feminino nas artes visuais. A volúpia dos sentidos aguçada pelo olhar, pelo tocar e pelo adentrar peças feitas para serem tocadas, obras arquitetônicas para serem vivenciadas. Minhas peças não chegaram nesta dimensão espacial, minha escala ainda está próxima de objetos portáteis, levados no colo ou mesmo no ventre... Porém, nossas obras suportam em si a força das pequenas vênus, do Paleolítico, comemorando a vida, a renovação dos ciclos.

Judy Chicago, festejou a vida e as realizações femininas com a grandiosa obra The dinner party. Também celebro os múltiplos significados da cerâmica e do vir-a-ser de um recipiente na ótica do feminino. Em sua grandiosa obra, Judy celebrou e serviu uma belíssima mesa de jantar para mais de mil mulheres: tanto as míticas, como as de carne e osso. Para cada uma das 39 mulheres da mesa de jantar foi "servido" um prato especial, pintado ou esculpido por outras mu- 
lheres - uma grande ceia feita por mulheres e para mulheres. Prato é também um objeto feito para conter os alimentos e as taças, feitas para conterem os líquidos. Portanto, recipiente na sua essência. Os pratos e as taças da instalação The dinner party, assim como minhas peças, foram feitos em cerâmica. Logo, são fruto do ventre da terra germinadora. Reproduzem-se em série através do torno ou do molde, porém não deixam de ser peças especiais, porque em cada uma delas há uma diferenciação que a torna única.

Com Ana Mendieta, o feminino foi mostrado através da sua autorrepresentação em suas silhuetas. Tentando se livrar de um forte conteúdo cultural que o corpo feminino carrega, seja através da exaltação da beleza ou do receio da conotação de objeto sexual, Mendieta encontrou uma forma de representar seu corpo diretamente na terra, associando suas energias com os elementos naturais: marcas de um corpo feminino com fogo, terra e água. Formas femininas feitas na terra e com terra, uma busca por suas raízes e origens. Nossos trabalhos se cruzam na medida em que necessitam indagar sobre a relação da mulher com a terra, a relação dos seres com sua procedência, com o princípio.

É preciso que eu admita, neste ponto, que minha primeira fonte de inspiração, foi sem dúvida, as múltiplas representações da Grande Mãe. As vênus esteatopígicas me ajudaram a elaborar conceitos sobre a plástica na cerâmica. Dentro de cada peça ocada e oca, côncava, vazia, trago a memória do passado no simbolismo do pote como morada dos mortos.

Há quem defenda que não exista mais uma "arte de mulher", ou seja, uma arte essencialmente feminina, feita por e para as mulheres. A arte, neste sentido, é universal, acessível e atingível por todos: homens e mulheres de todas as idades e crenças. Neste ponto, este livro quer defender apenas que só podemos produzir uma arte com base em nosso repertório pessoal e subjetivo. Isso quer dizer que expressamos nossos pensamentos, idéias, emoções, sensações, com base naquilo que somos, vivemos, acreditamos, aprendemos, assimilamos considerando que todos esses pontos estão extremamente atrelados às nossas raízes culturais, na qual nascemos e não escolhemos. Logo, 
não seria possível separar a autora/artista da sua realidade única, seja como mulher, brasileira, ceramista e pesquisadora do século XXI.

Assim, fecho este ciclo, mostrando como todos esses pontos colaboraram para a minha transformação, através da forma e do conteúdo. A forma - diretamente ligada à cerâmica, pois este é um suporte extremamente orgânico e plástico, que durante os séculos se moldou conforme nossa vontade. O conteúdo - metaforicamente ligado às mulheres que se tornaram artistas - que transformou minha própria maneira de ver e fazer arte. Logo, isto que lhes foi apresentado é, antes de qualquer coisa, fruto de trabalho contínuo de pensamentos e mãos, de sentimentos e ações. Gerado por e através de um repertório poético, artístico, cultural, mental, emocional. Gerado de dentro para fora. Revelado em seu interior: um recipiente exposto.

Eu faço aquilo que sou. Sou aquilo que faço. 



\section{Anexo}

"A matéria pura vive, sonha, pensa e se esforça como um bom operário. O sonho da amassadura eleva-se assim ao nível cósmico: o sonho do ceramista é uma imensa masseira onde as terras diversas se almalgamam e se misturam aos fermentos"

Gaston Bachelard, A terra e os devaneios do repouso

Neste anexo, selecionei alguns desenhos, croquis, projetos e poesias feitos ao longo da minha pesquisa teórica e prática. Eles foram feitos a lápis, lápis de cor aquarelado e também caneta higrográfica (ponta fina colorida). Criadas em momentos distintos, essas imagens (es)colhidas exprimem muito sobre a minha intimidade e foi extremamente difícil decidir me expor assim deste modo. Contudo, compreendi que com elas poderia agregar maior valor à serie Mulheres recipientes e, portanto, isso seria de fundamental importância para visão total de meu trabalho.

O desenho tem um grande papel no meu processo criativo: ele é, muitas vezes, o primeiro local onde uma idéia é manifestada. Não necessariamente a idéia de uma escultura surge através do desenho, na grande maioria são criações que complementam algum projeto 
escultórico ou de instalação. Essas ilustrações estão, quase sempre, acompanhadas de palavras ou textos poéticos, que associam outras informações às imagens. É possível observar que algumas dessas imagens se distanciam tanto da peça final, que os desenhos acabam se tornando trabalhos independentes, com uma tênue relação com as esculturas. Sartre, em seu ensaio fenomenológico A Imaginação explana justamente sobre essa relação entre a representação e objeto representado: "a imagem é uma coisa, tanto quanto a coisa da qual é a imagem. Contudo, pelo fato mesmo de ser imagem, recebe uma espécie de inferioridade metafísica em relação à coisa que ela representa" (Sartre, 2008, p.10). As imagens e desenhos apresentados são, na grande maioria, independentes do objeto representado. Logo, não se tornam inferiores porque não representam, eles existem em si mesmo.

Há alguns casos, porém, em que especificamente traduzo meus desenhos em formas tridimensionais. Exemplo disso são as Figuras 26/27/28/29/31/32 em que projetei primeiramente as peças no papel para depois transpô-las no barro. Ocorre que as idéias surgem em momentos inesperados, em situações em que não estou em atelier e o desenho acaba por se tornar a melhor maneira de dar forma à elas.

O que exponho aqui, é uma profusão de idéias e desafios que foram costurados com uma mesma coerência temática e simbólica, retomando ciclicamente como um alinhavo, minha antiga pesquisa sobre o universo feminino. 

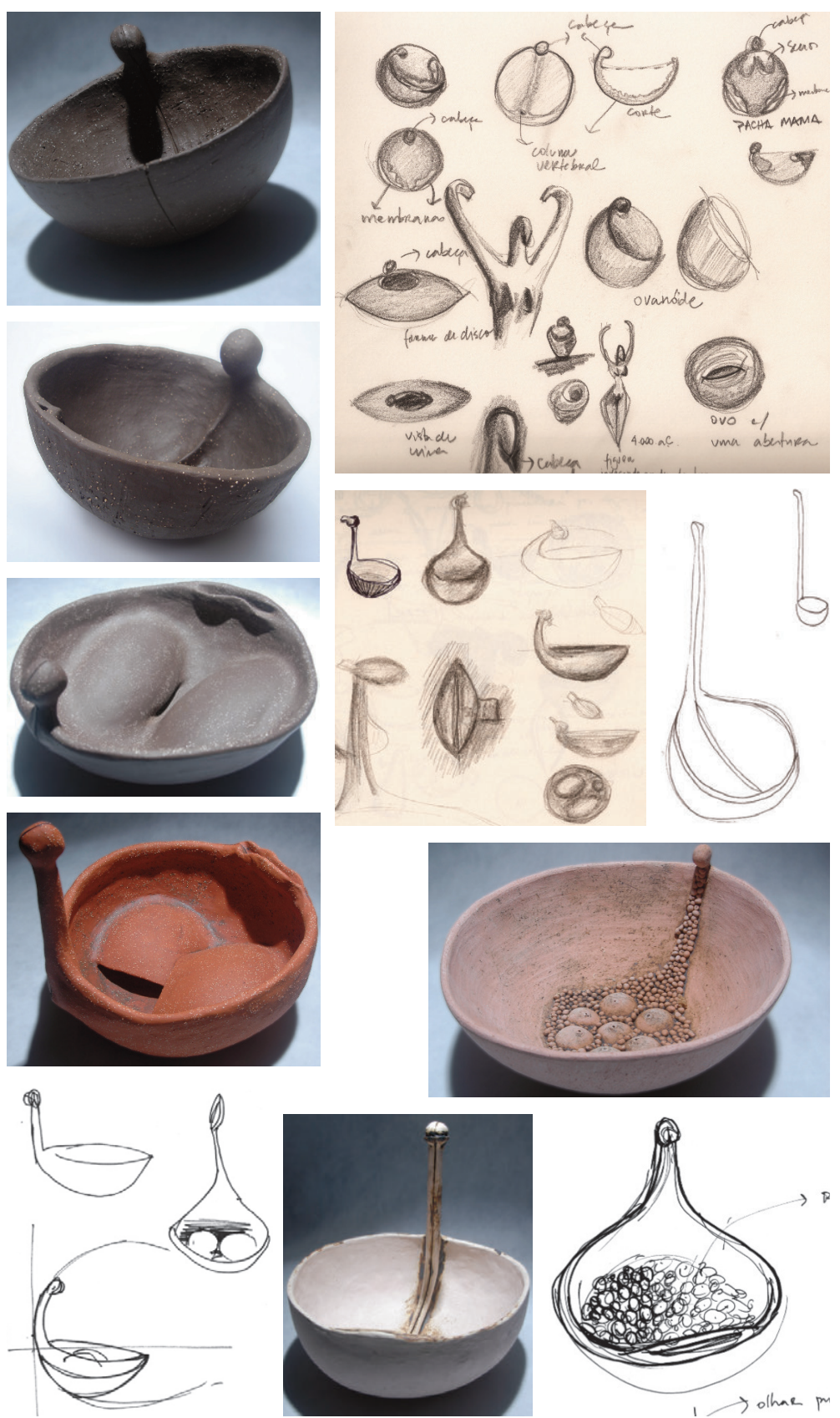

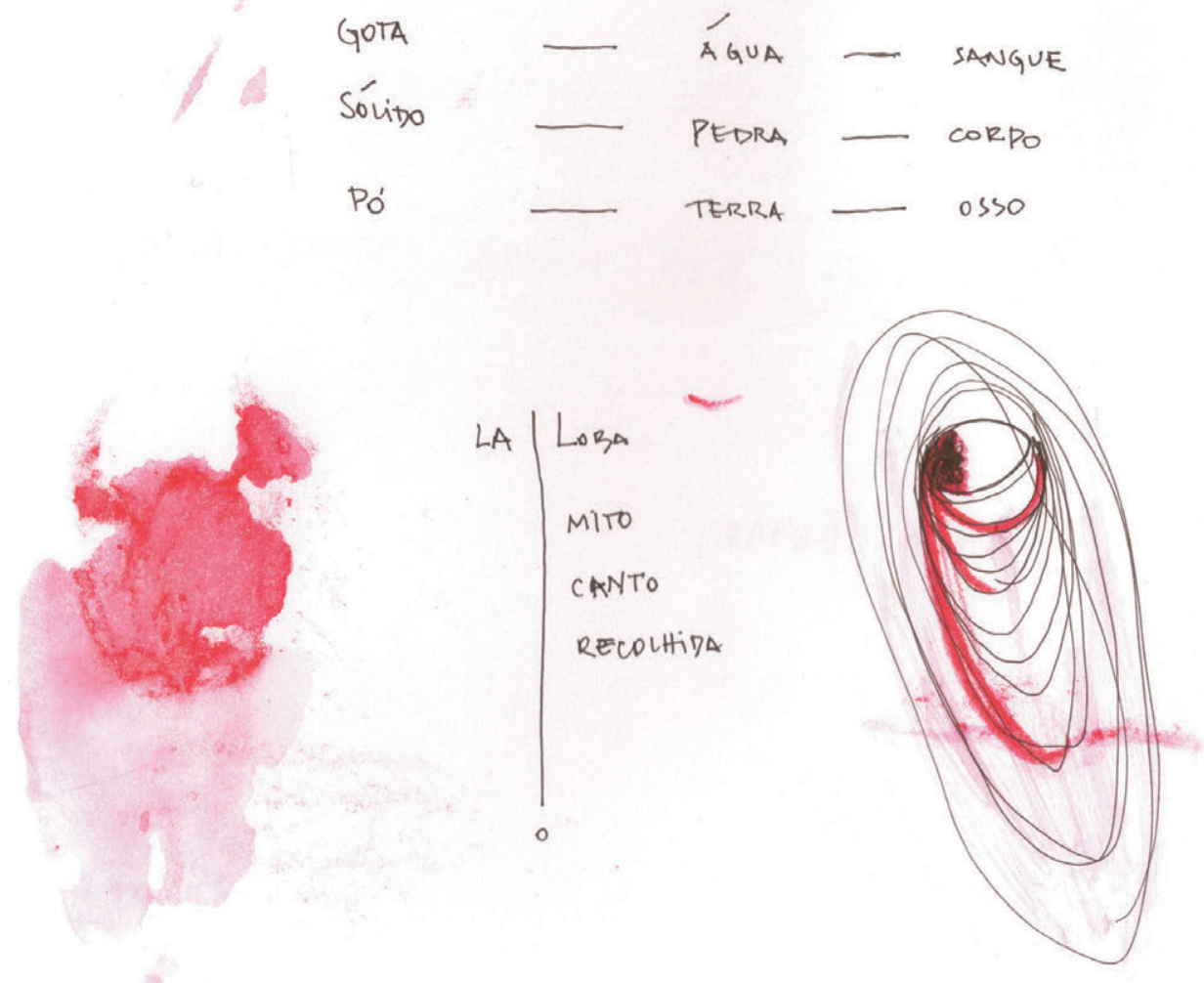

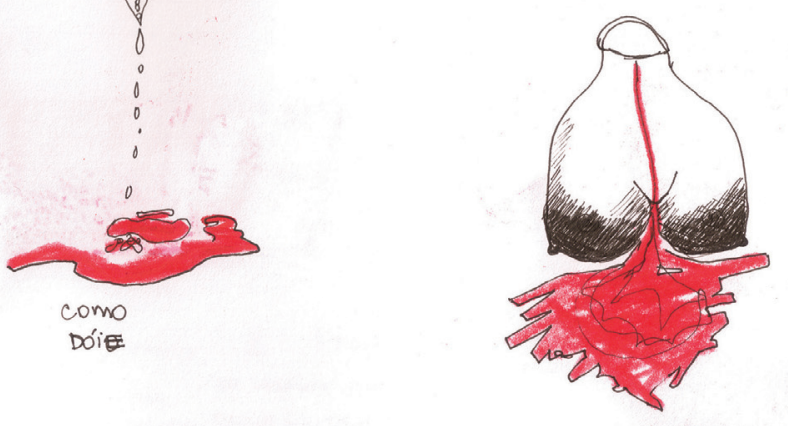


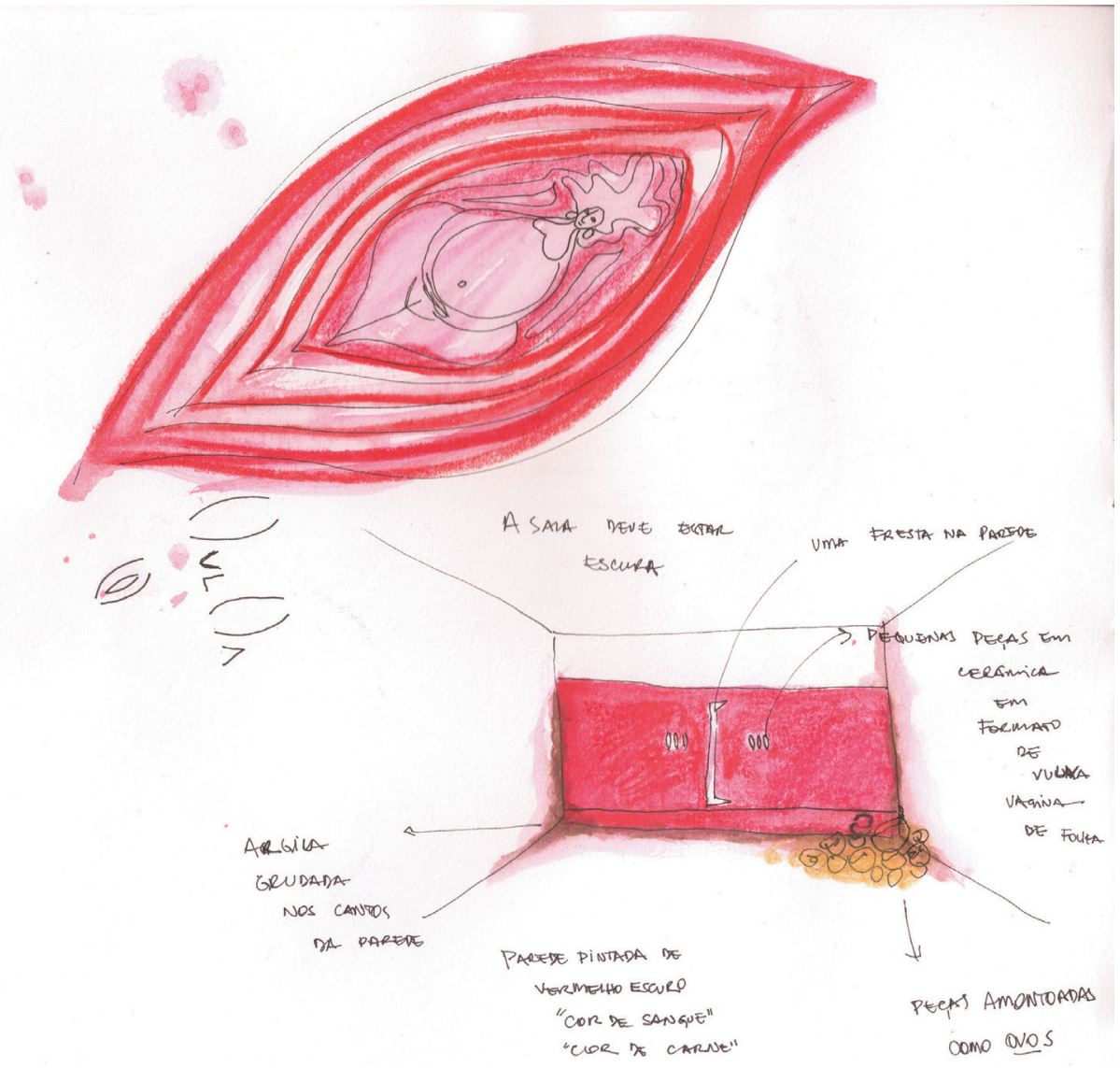




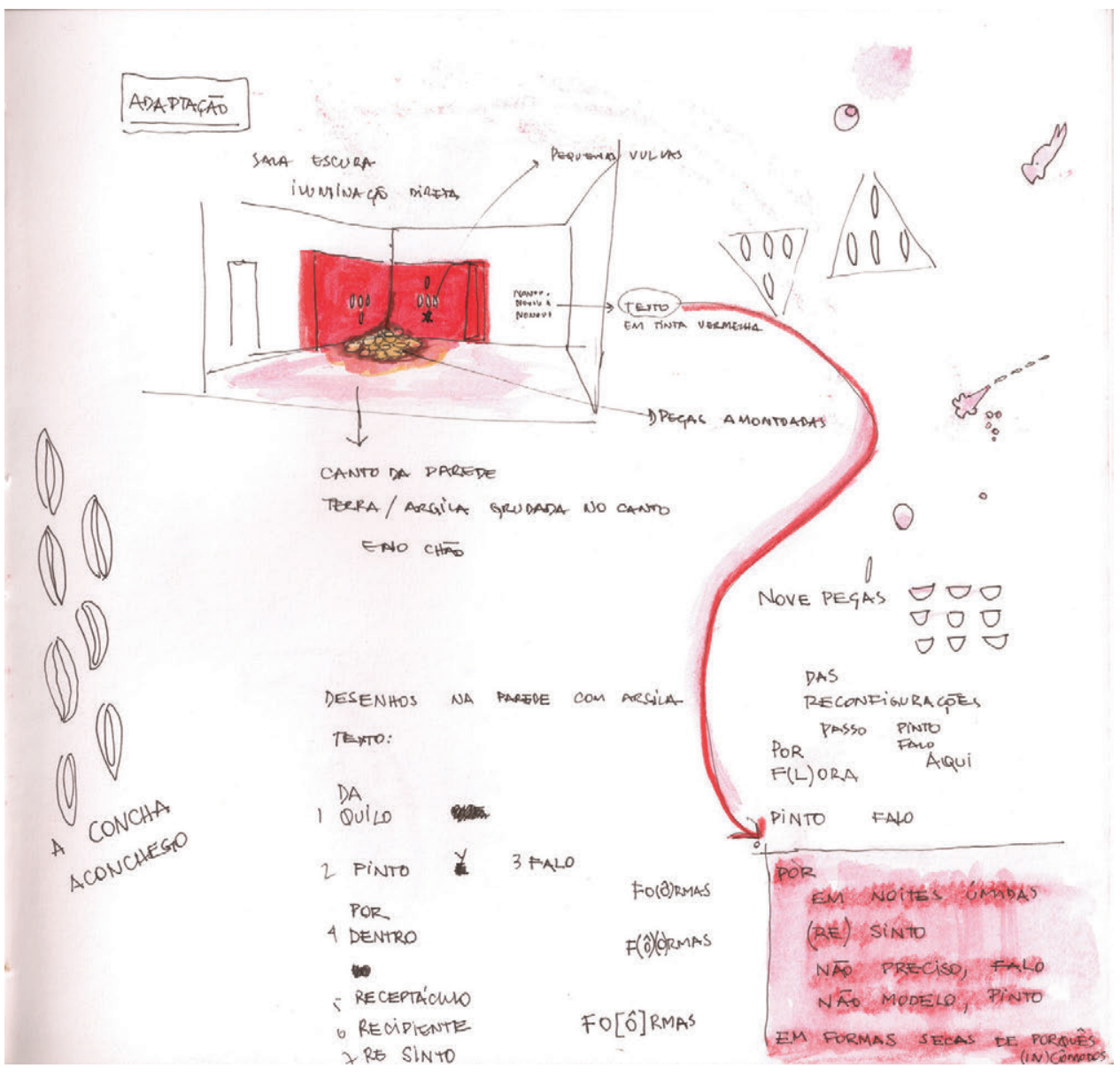




$$
\text { (4) }
$$



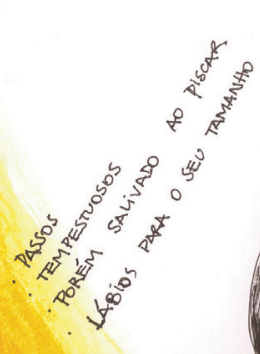

OKO

OCO

OVO

OWO

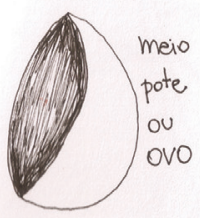

RECEBO

REEONCAVO

REREPTÁCULO

RECIPIENTES

SABIO

E NEO CÁLIDO

GERMEN DAS COISAS CRIADORAS

ELA; CRIA-DORES

jGERA_DORES INALADAS

E misPoniveis aOS QUE dEgUSTAM

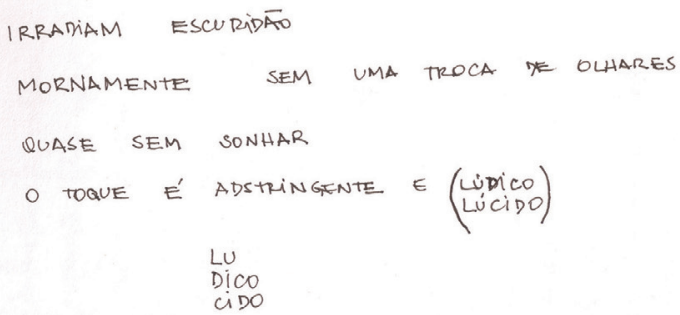




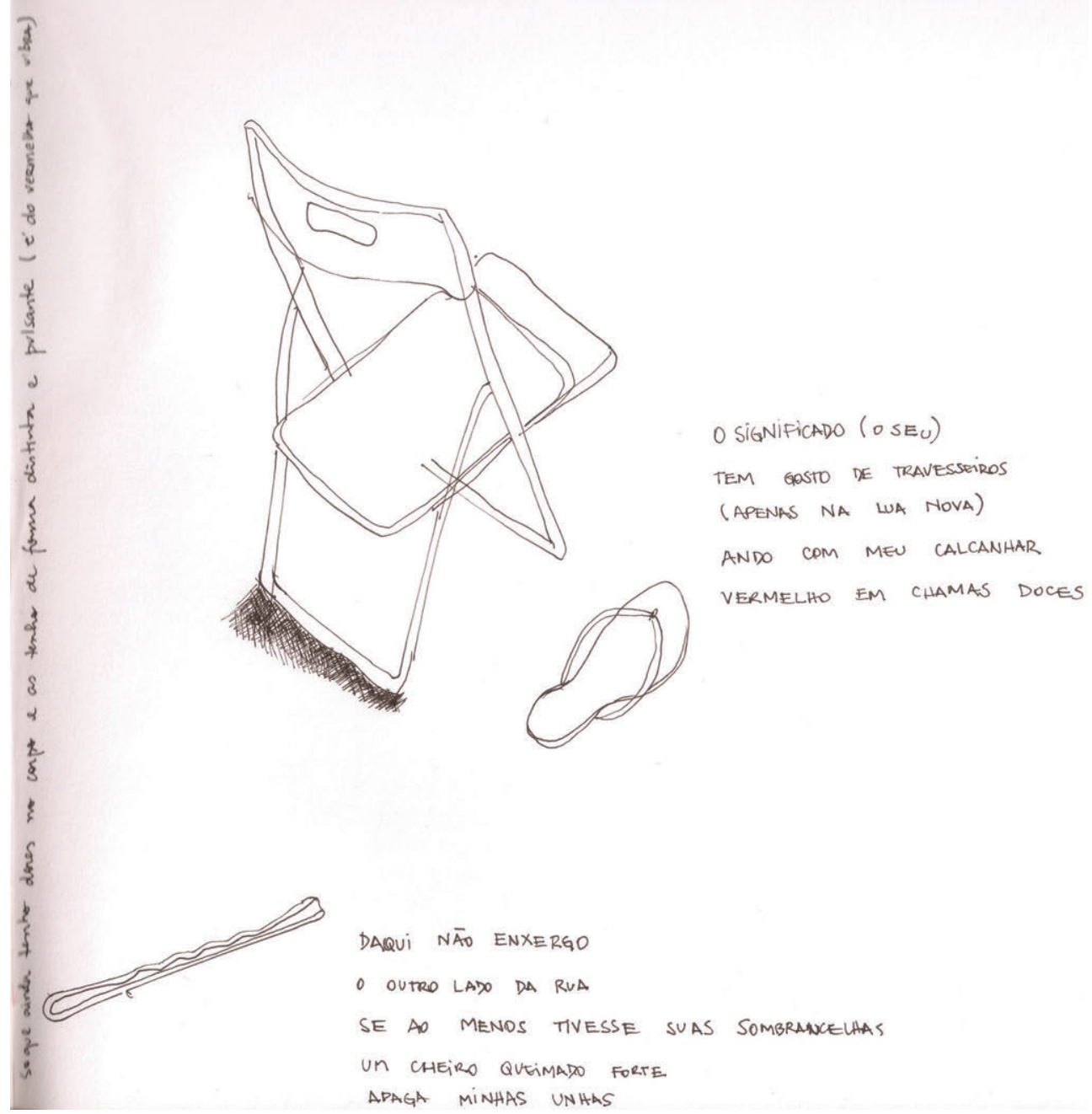




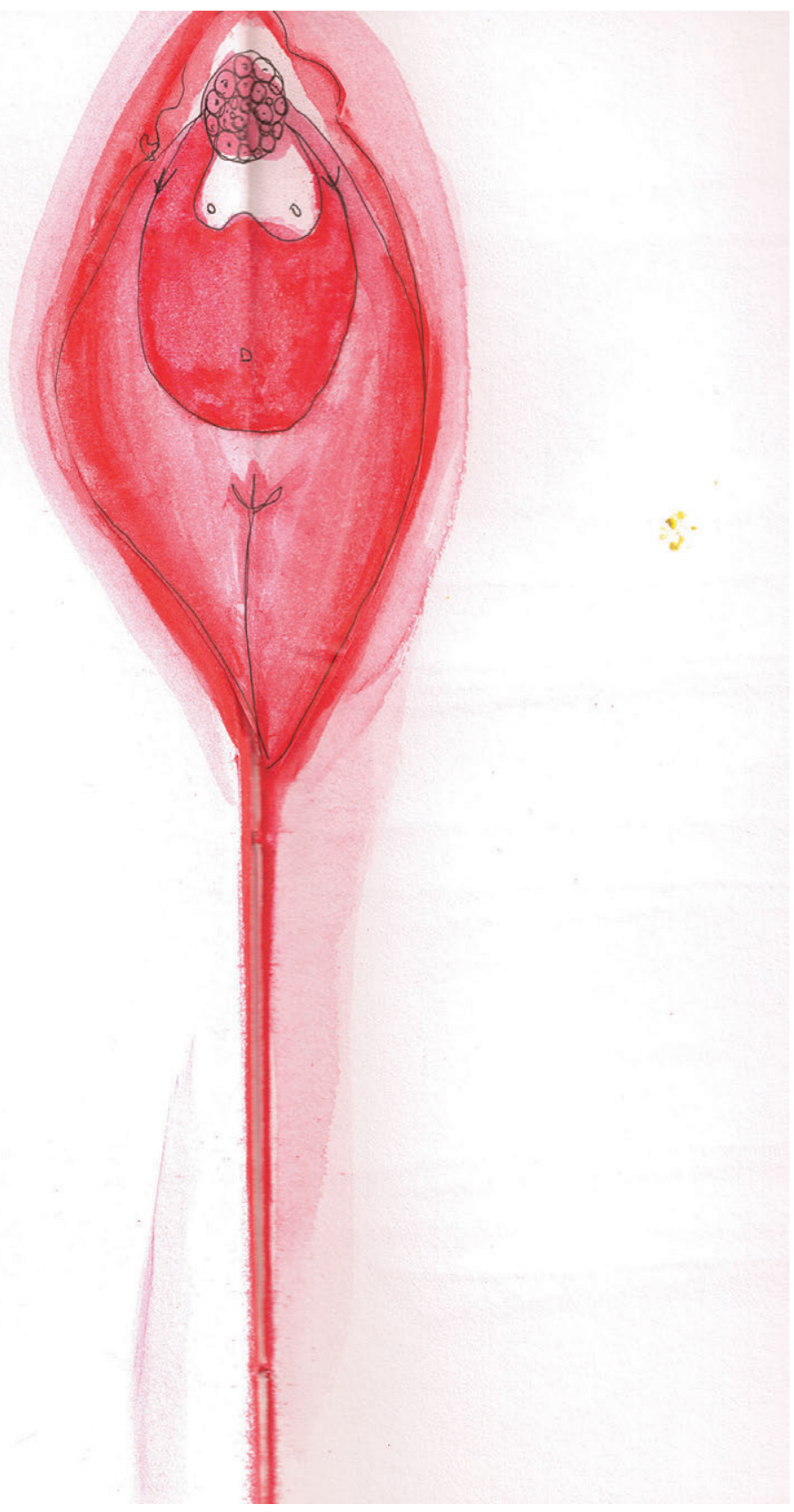




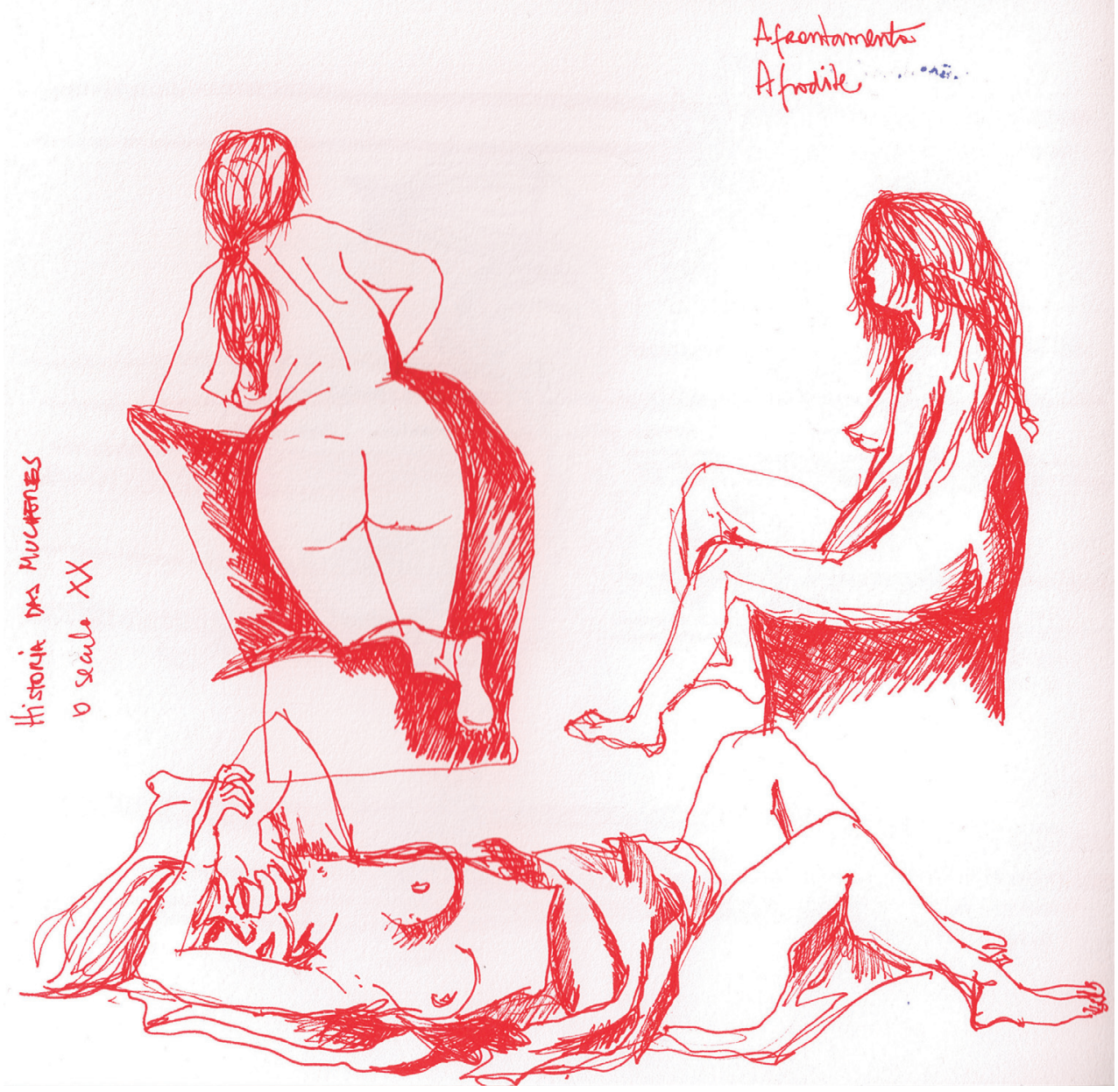




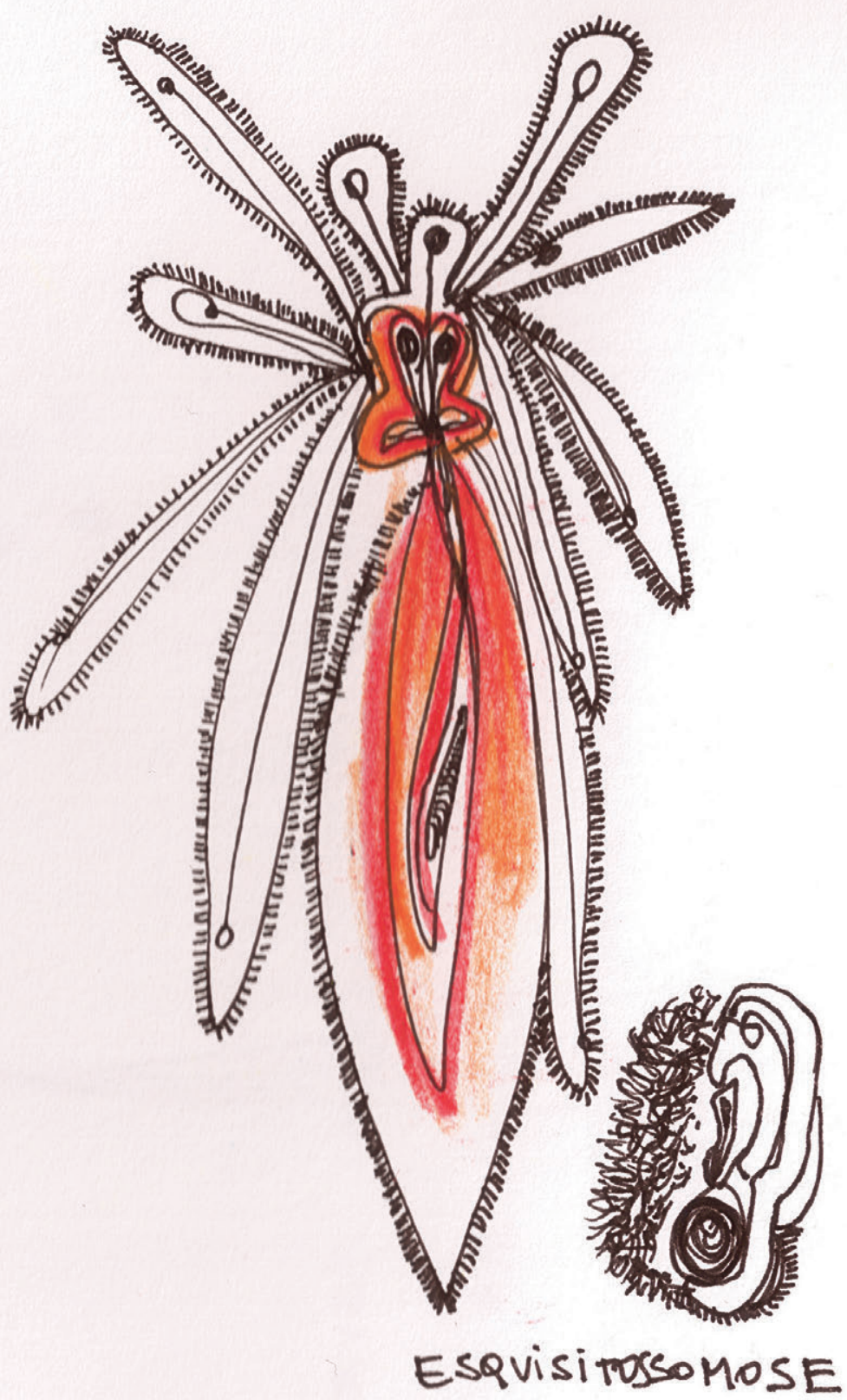




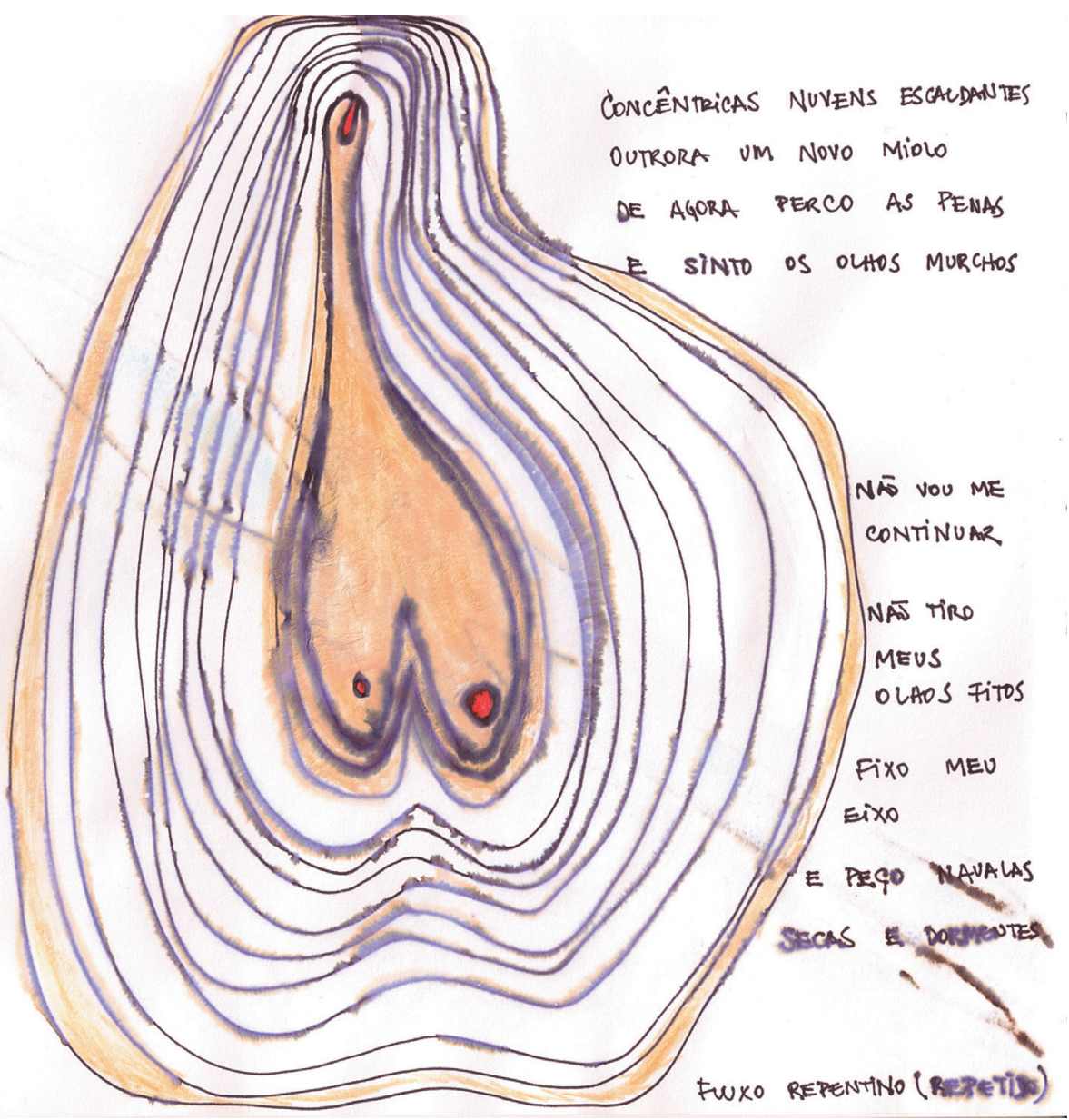




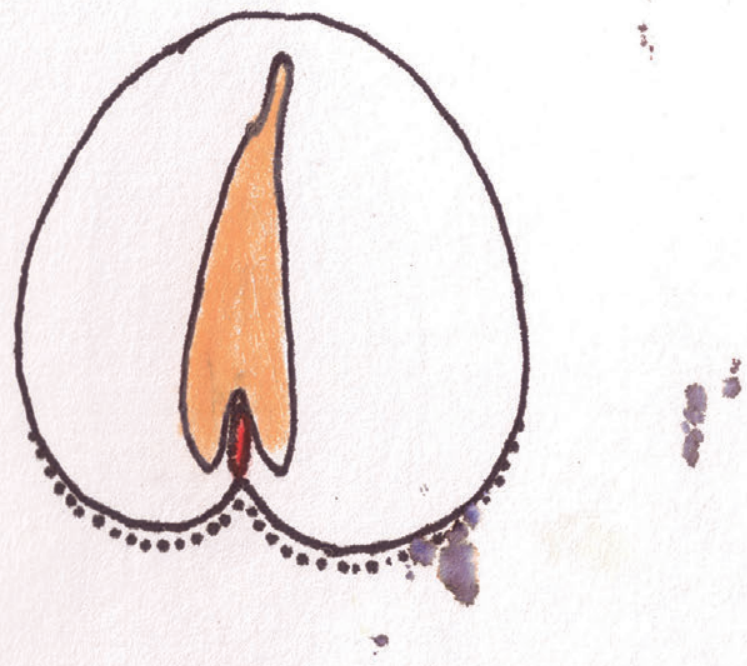

NESGA 


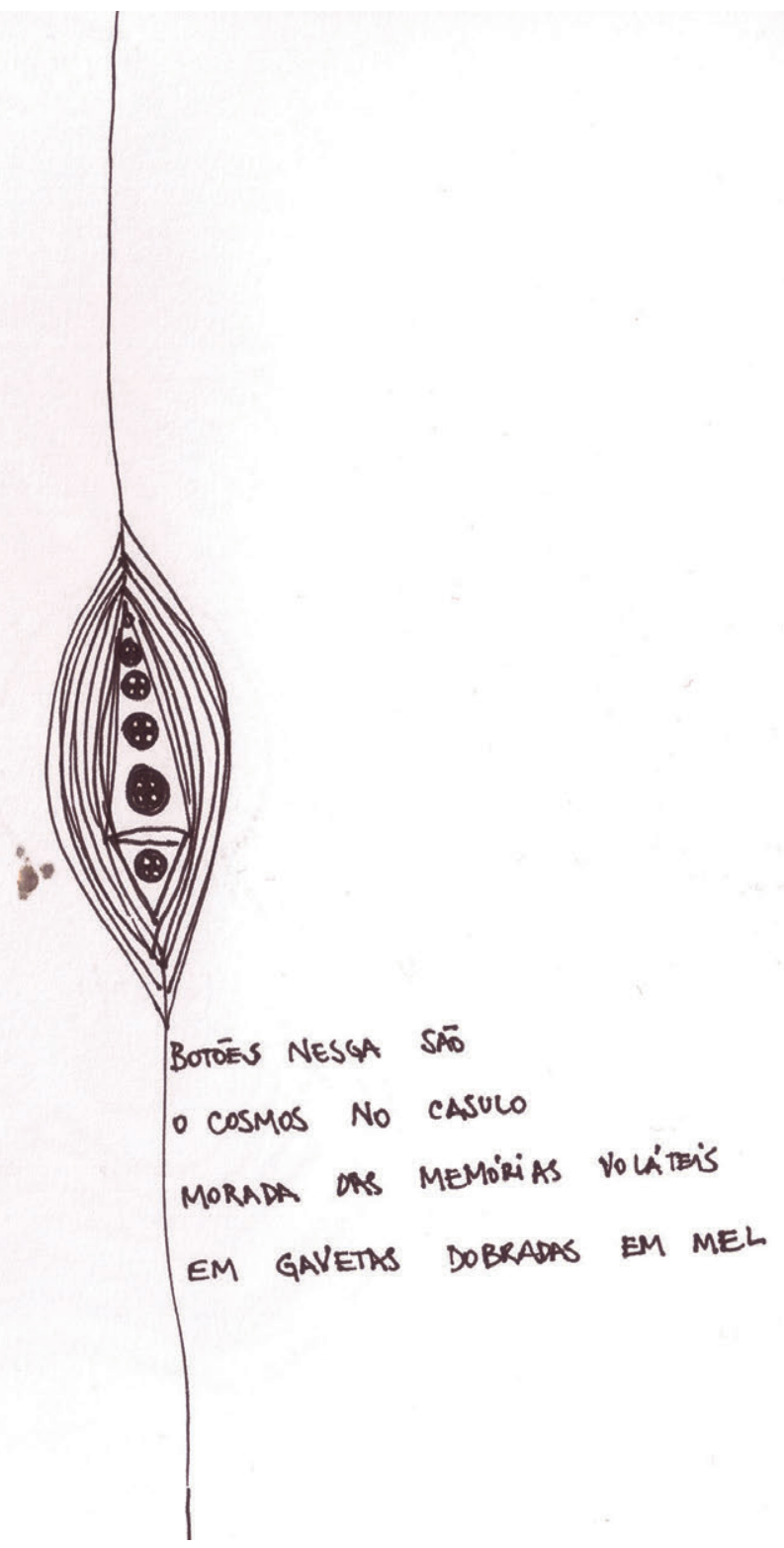





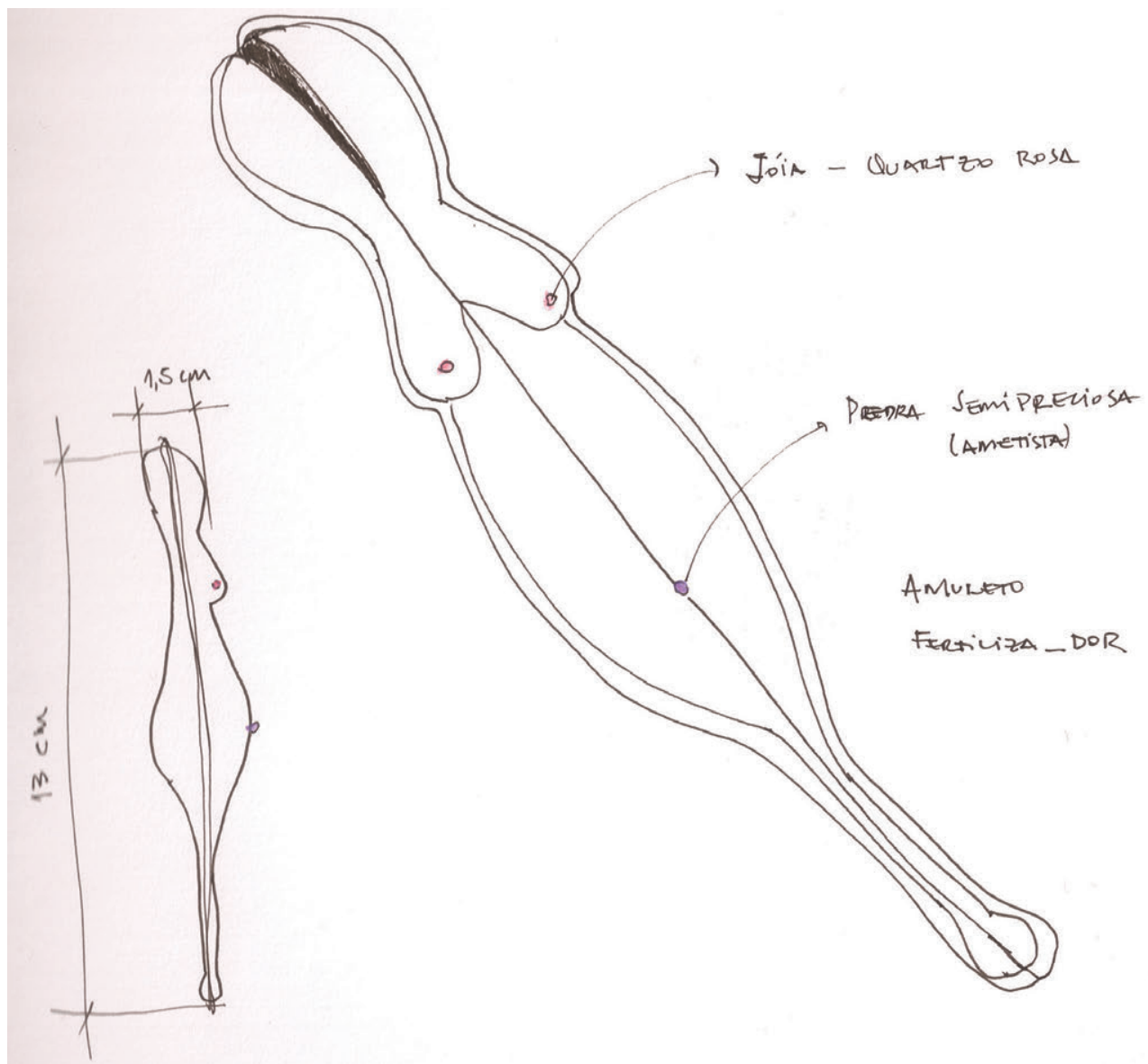


MULHERES RECIPIENTES 203

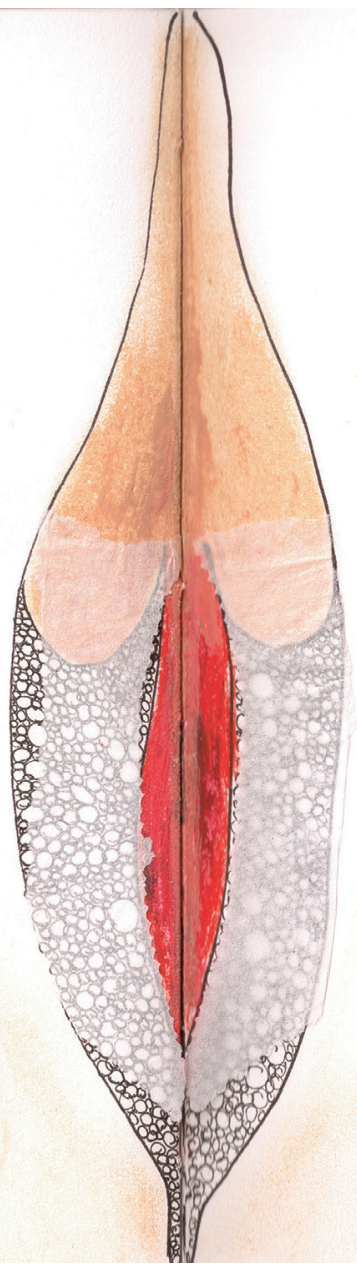




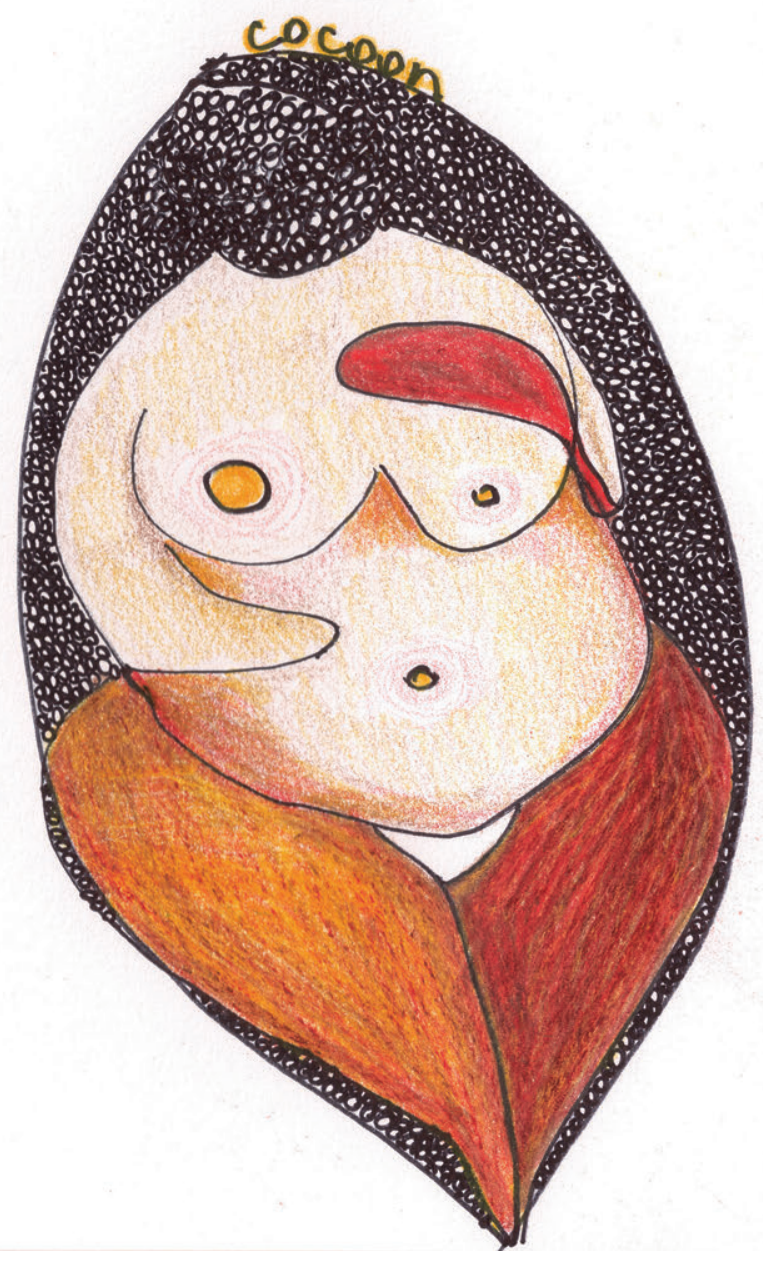



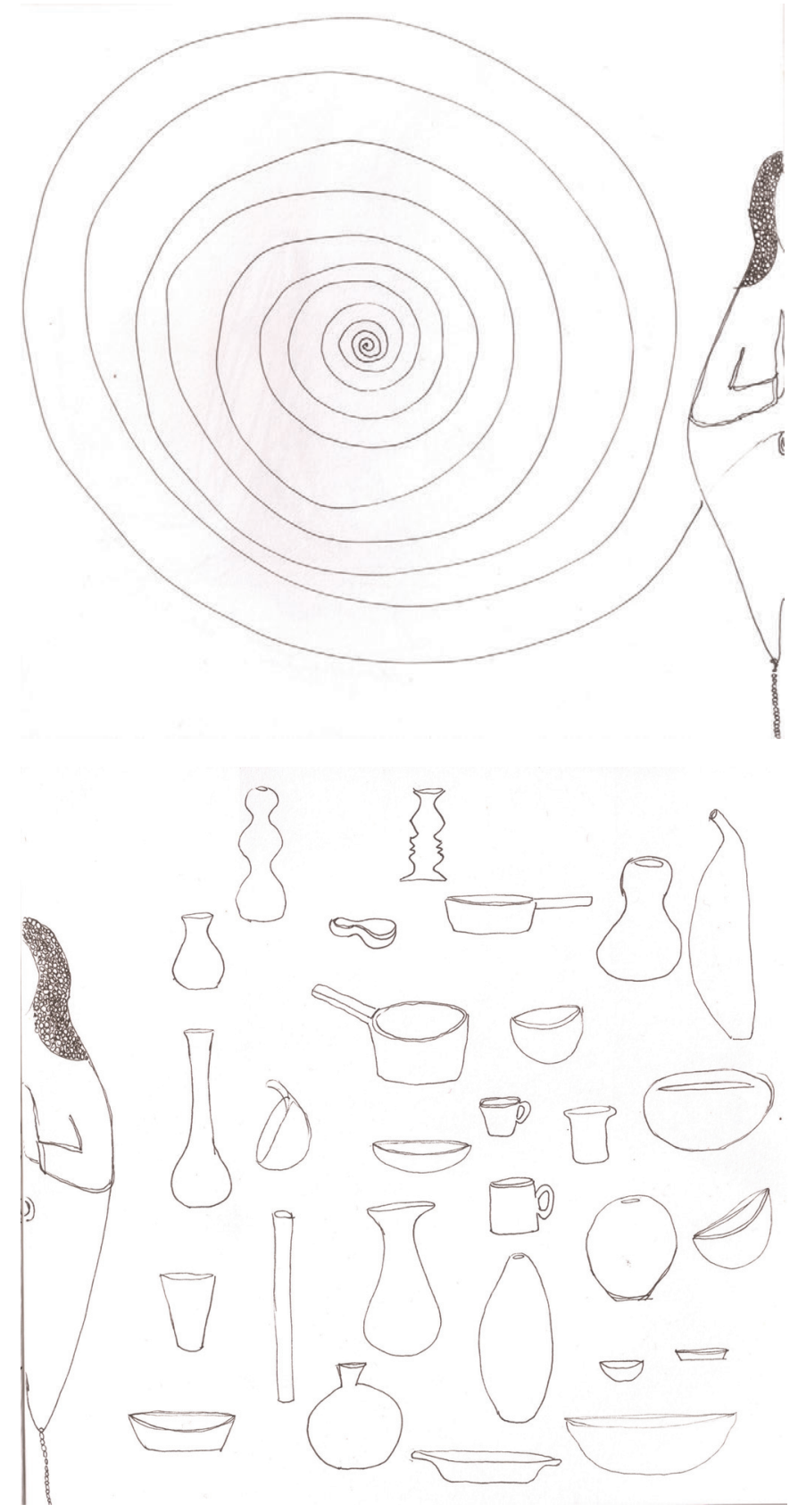


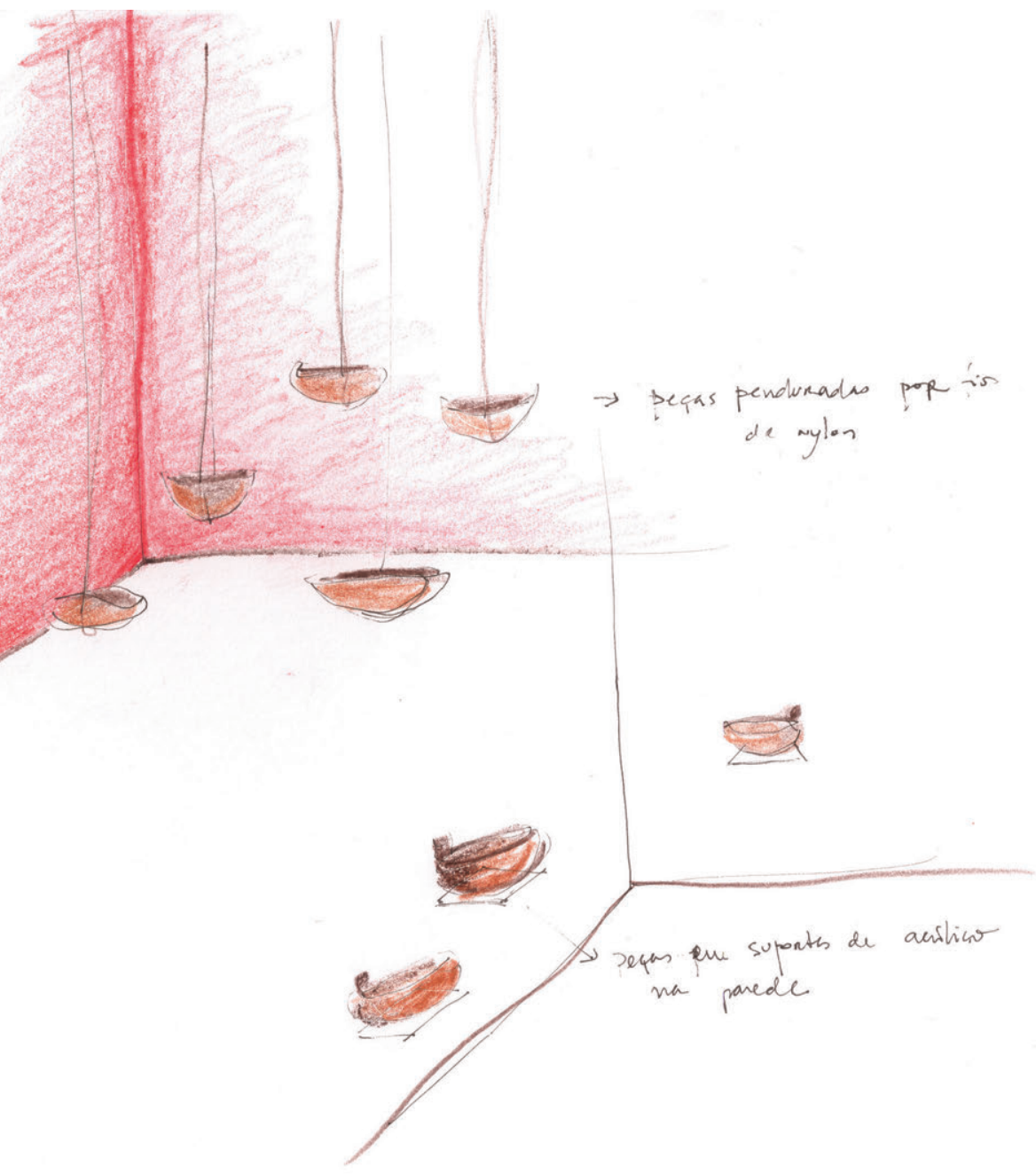


MULHERES RECIPIENTES

207

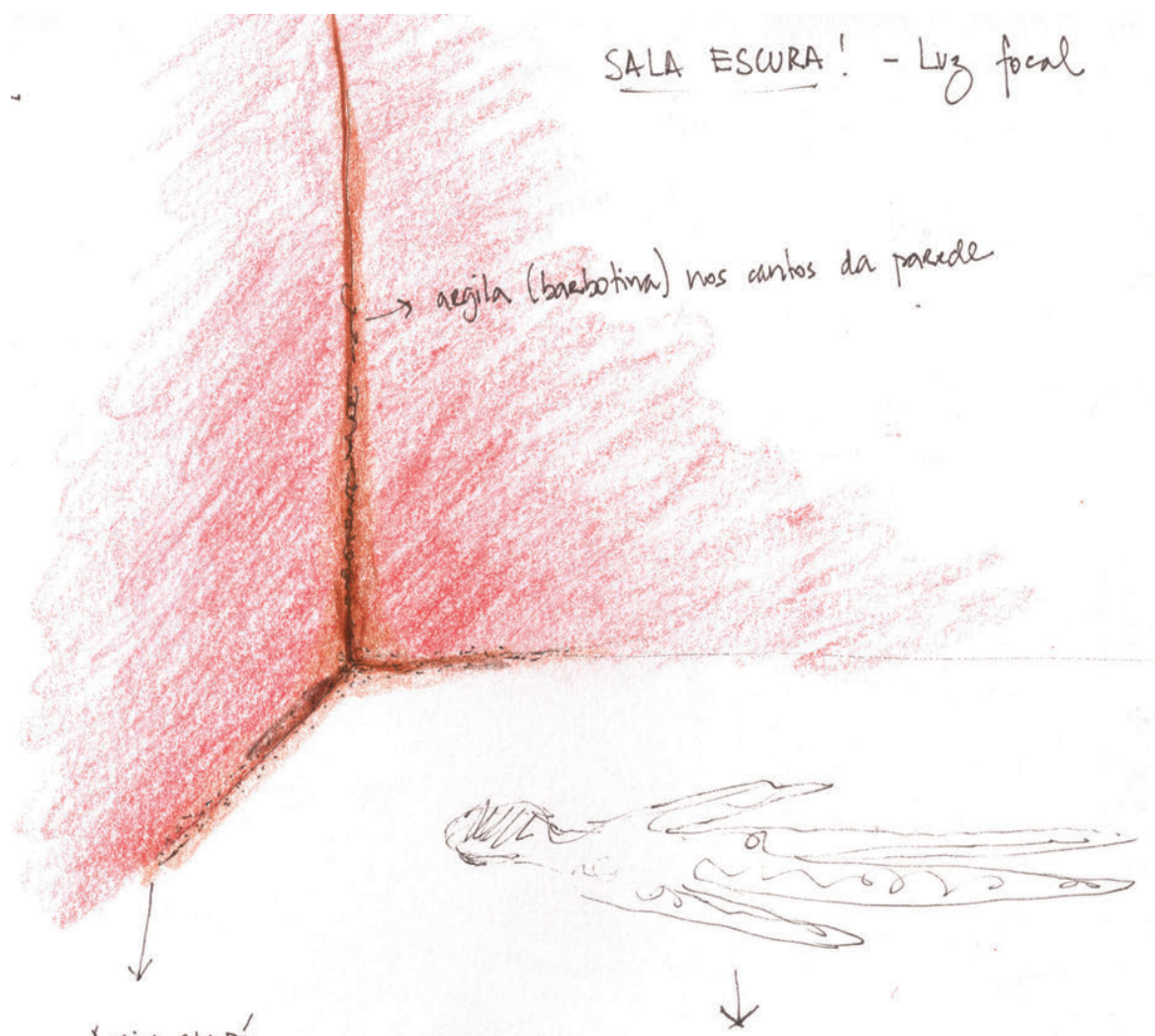

Argica em pó

Nos cantos

da sala
DESWHAR MINHA SILWETK preEnctier com Argila (BArbotina) 
208

FLAVIA LEME DE ALMEIDA
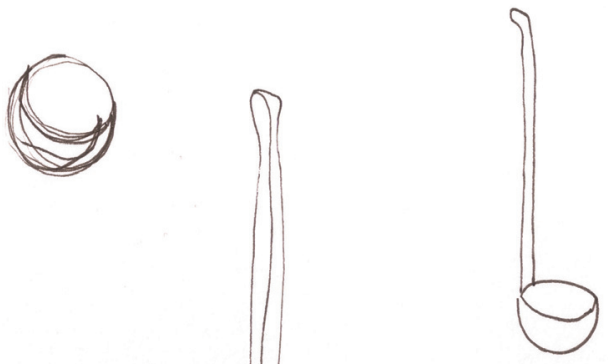

CONCHA DE COZINHA

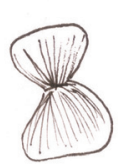

DO MAR

00

0

0

○

○

$\circ$

O

$\begin{array}{lll}10 & 0 & 0\end{array}$

0

$\diamond$

Q

○

Q

0

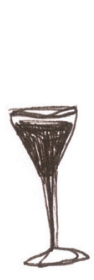

$00^{0}$

。

桪

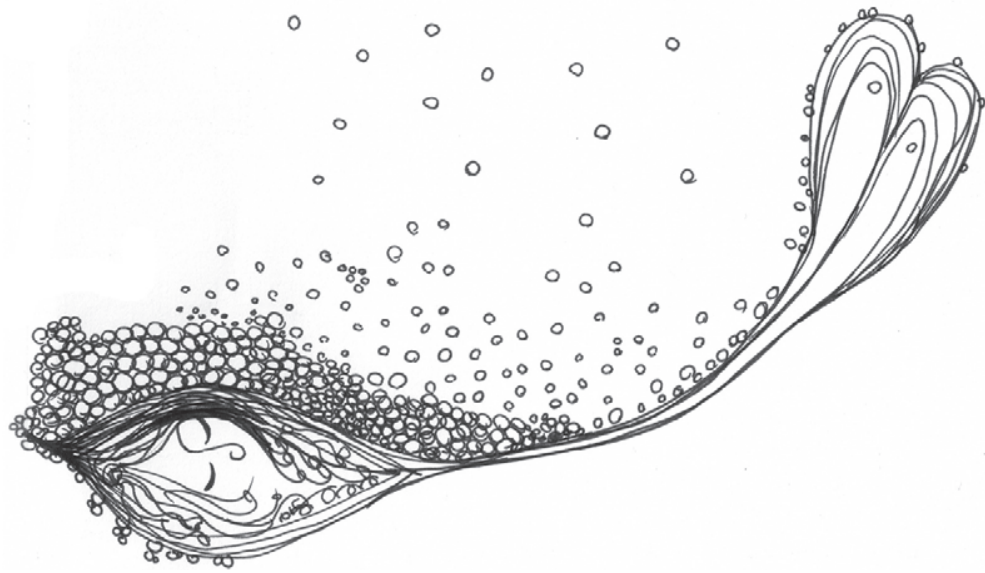




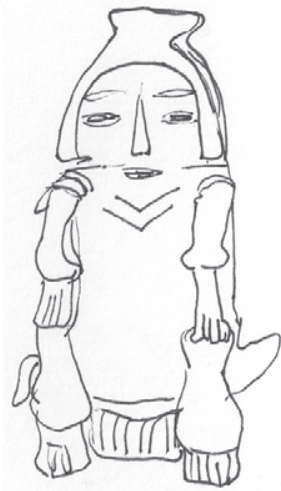

URNA FUNERÁRIA.

UTERO CERAMICO

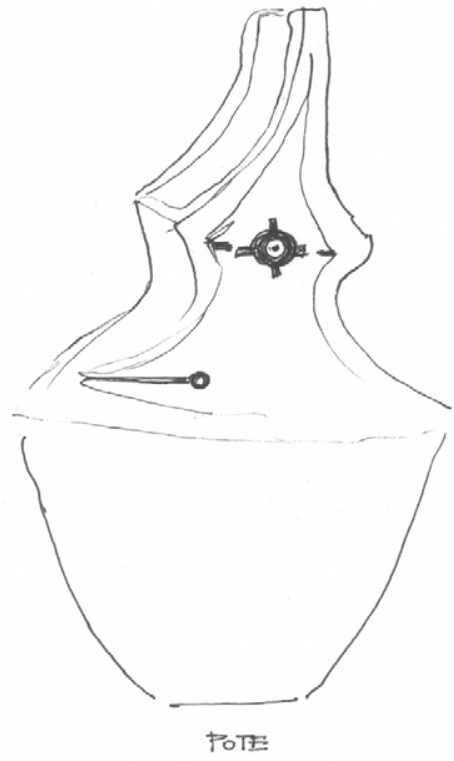

$\cup M$

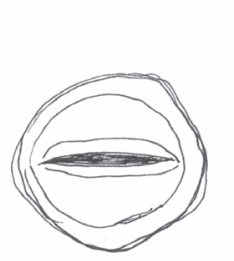

$\Longrightarrow$
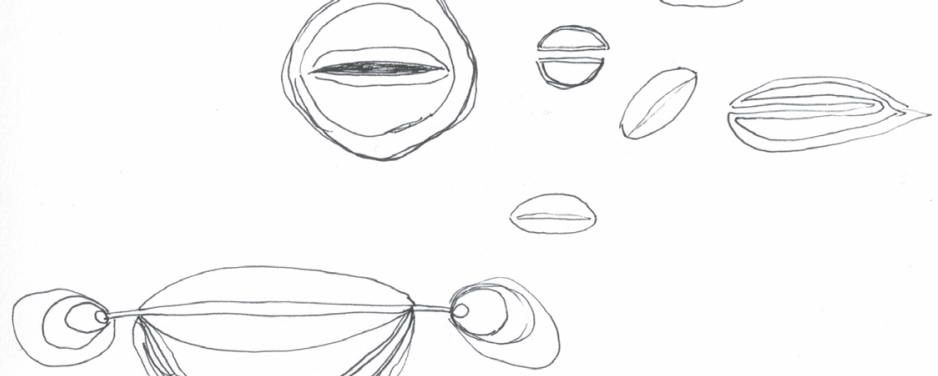

$$
\begin{aligned}
& \text { B.o.T.A.R. } \\
& \text { B.O.A. } \\
& \text { B. } 0.1 .4 . \\
& \text { B. } 0.1 . \\
& \text { B.I. } 0 \\
& \text { I. } 0 .
\end{aligned}
$$


FLAVIA LEME DE ALMEIDA

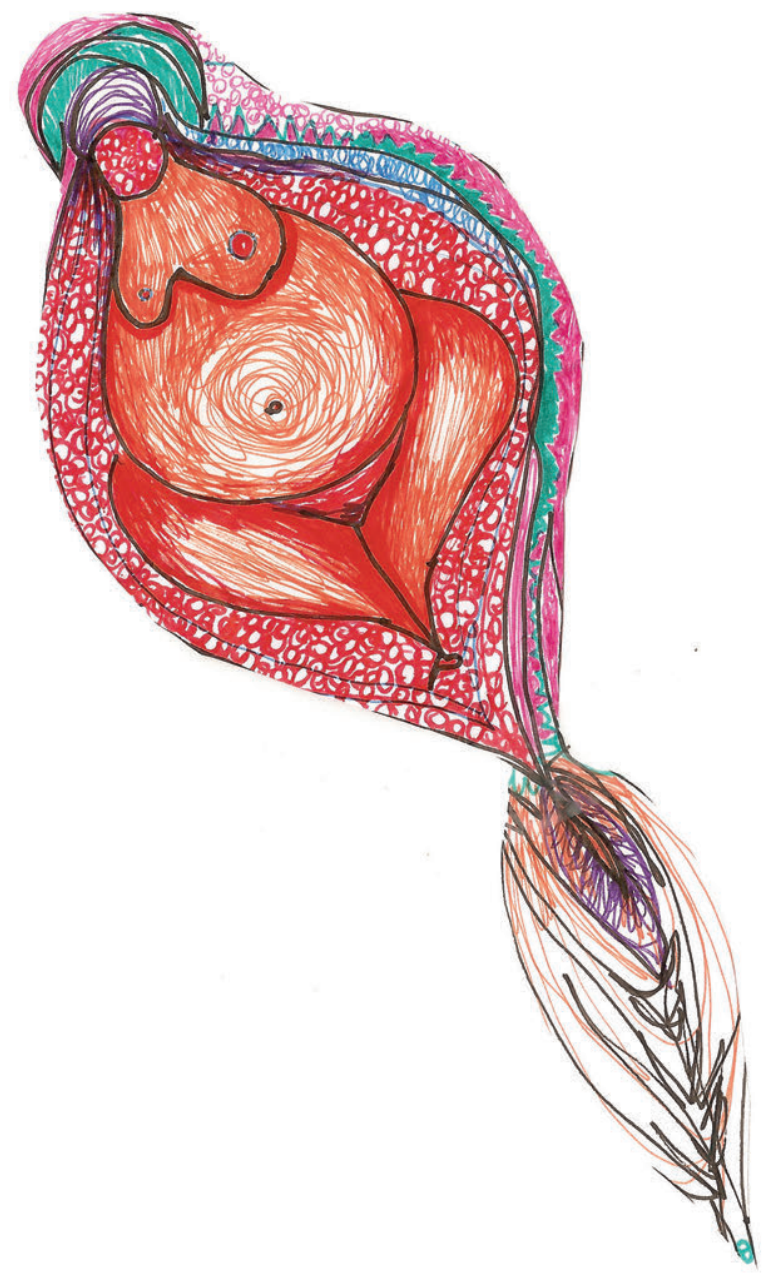




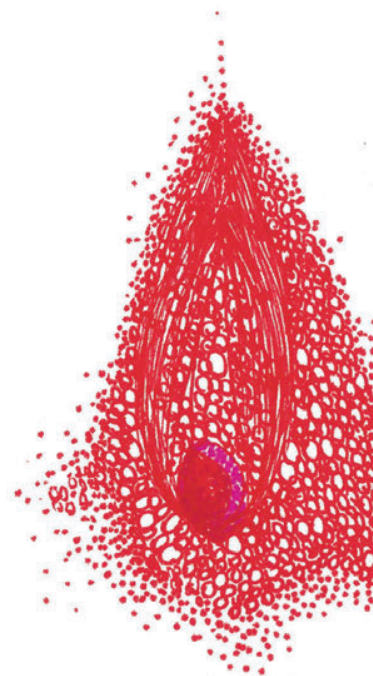

As partículas concentricas :

CUPIM. ETERO FORMIQ - UEIRO MURUNOUM MONTE. MUNDPREO PONTINHOS AgWTINADOS

CHORAM BOTOES DE GELO

PEDRA. BARRO. ÁGUA.

TUBERUULS RESPLANDECEM MUDAS. 


\section{pequenas \\ LALAS \\ NANAS \\ MAMAS}
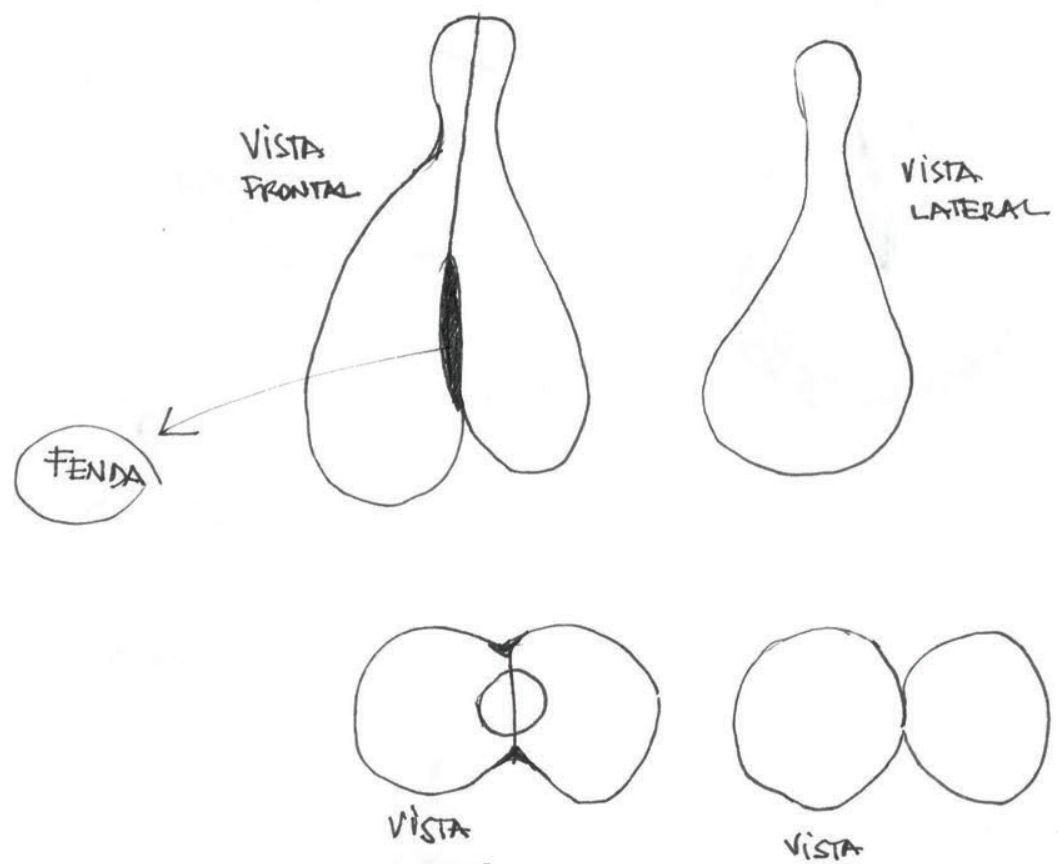

DE TOPO

INFErier 
MULHERES RECIPIENTES $\quad 213$

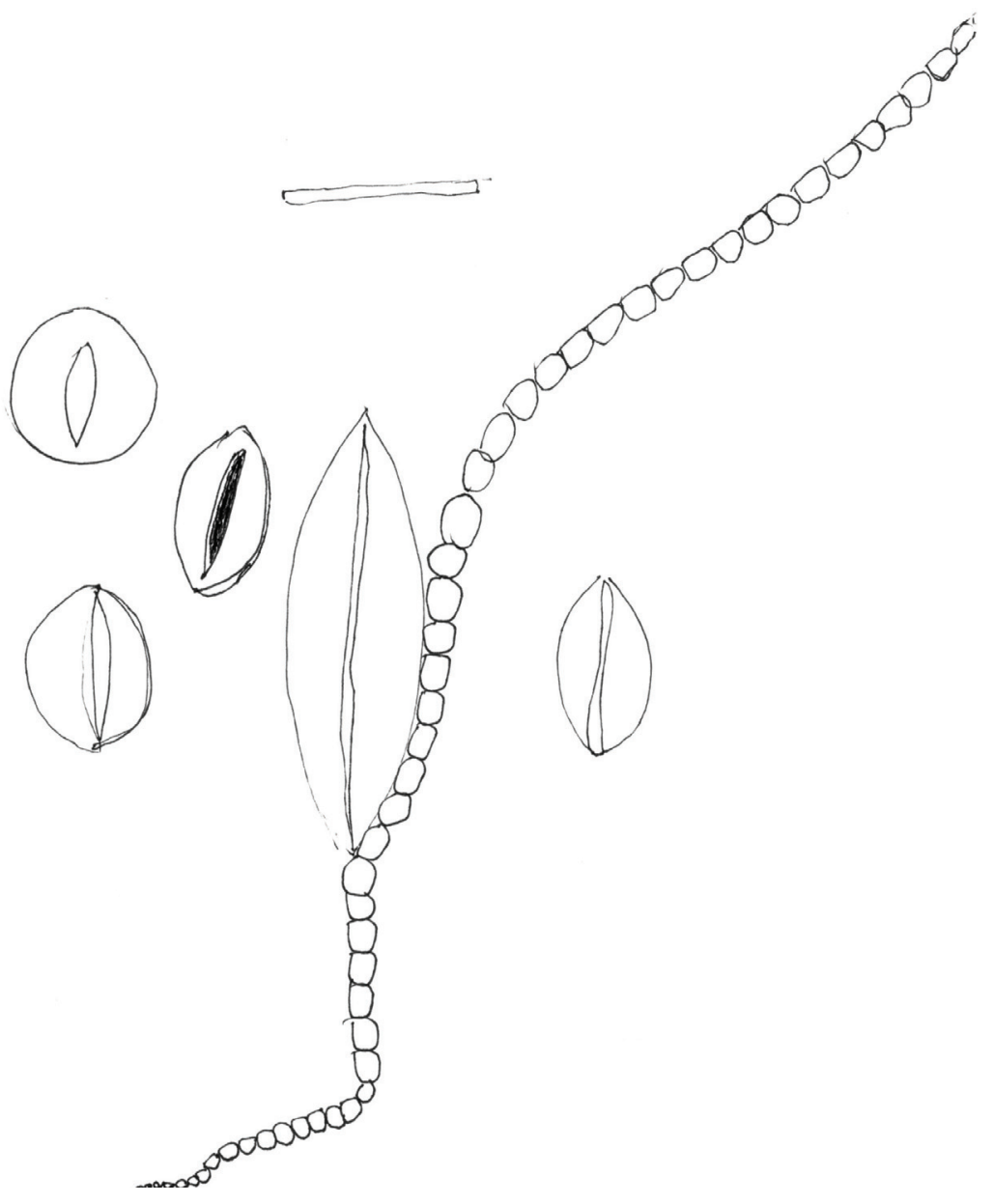


214 FLAVIA LEME DE ALMEIDA

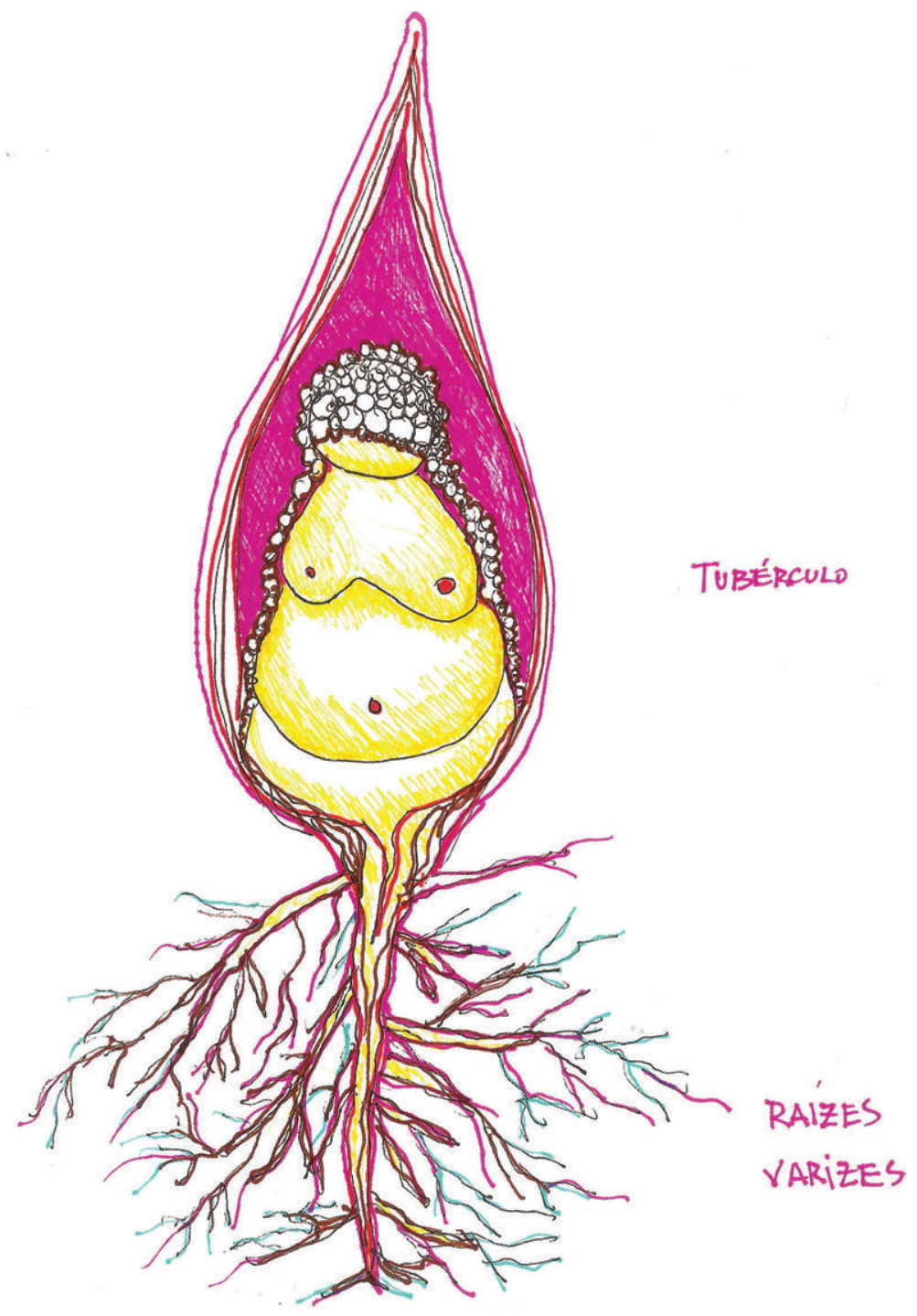



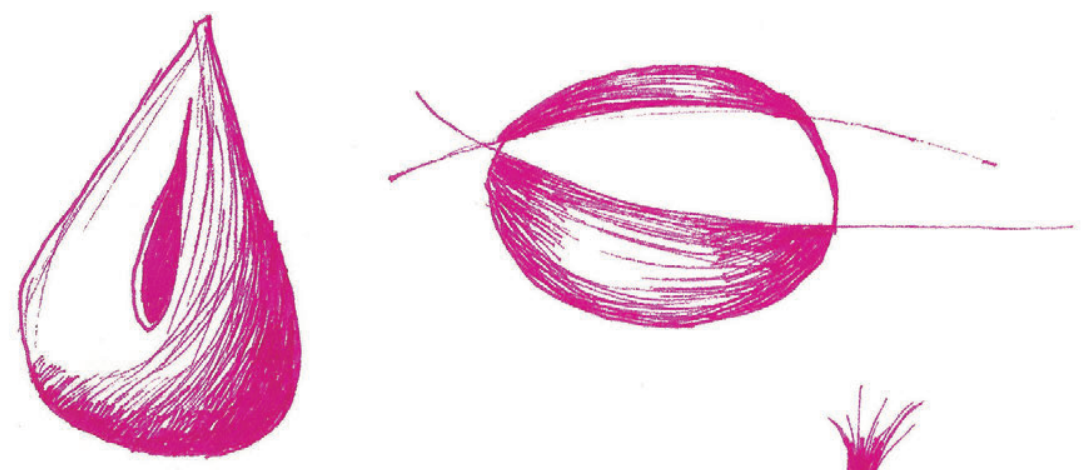

TER TEMPo Pra somhar...
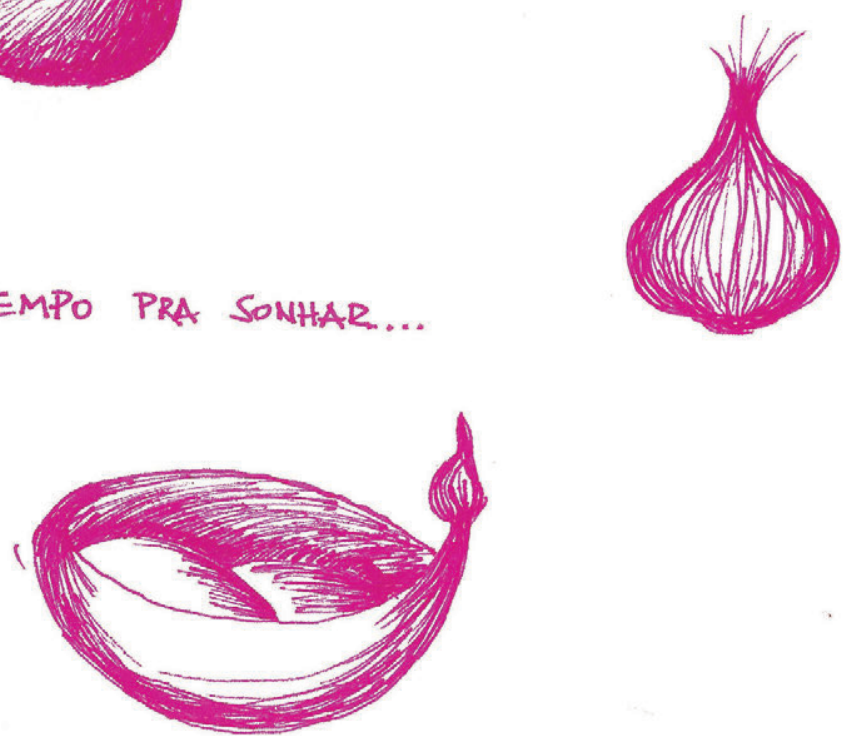


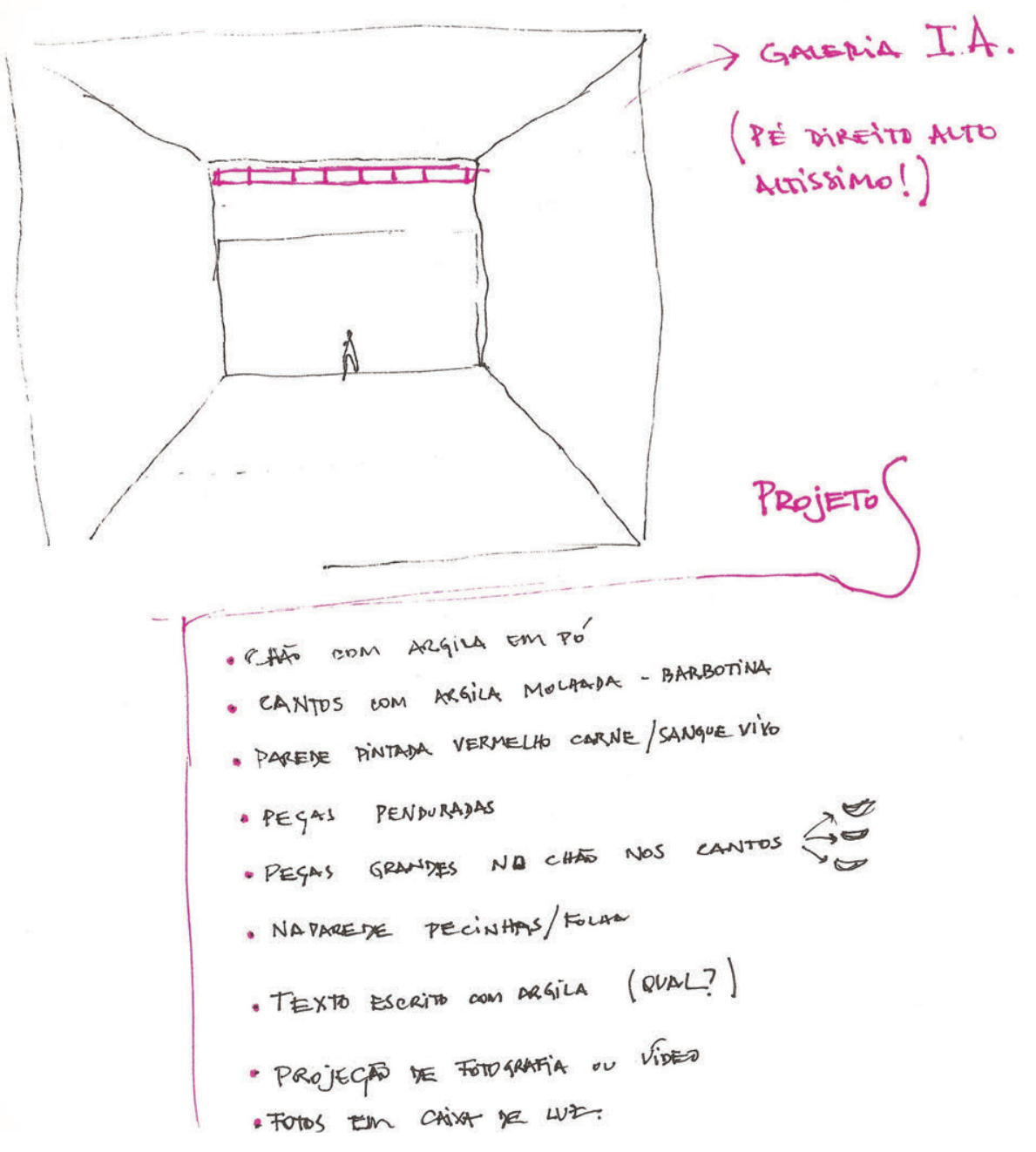




\section{SONHO:}

PECpS muiraquitás, foutas BONECOS DE Homem/munter: golinhtas - mi Niaruras em ceramía PRESPS COM BARBANUTE Projeto no sontlo uma ensinha de boneer d pecus de ceáninica. roots/artesamato:

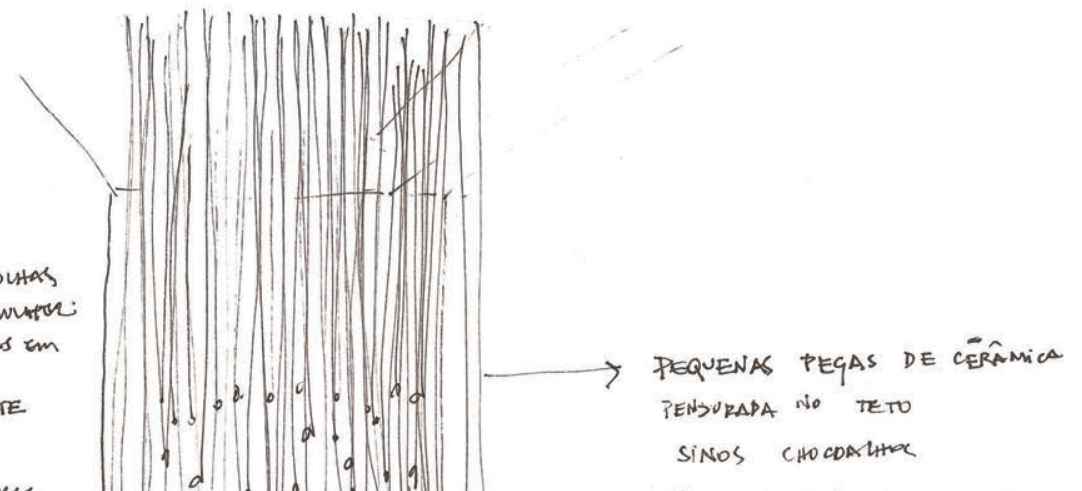
caruaru

Todas rizesal na mesma MTURA.

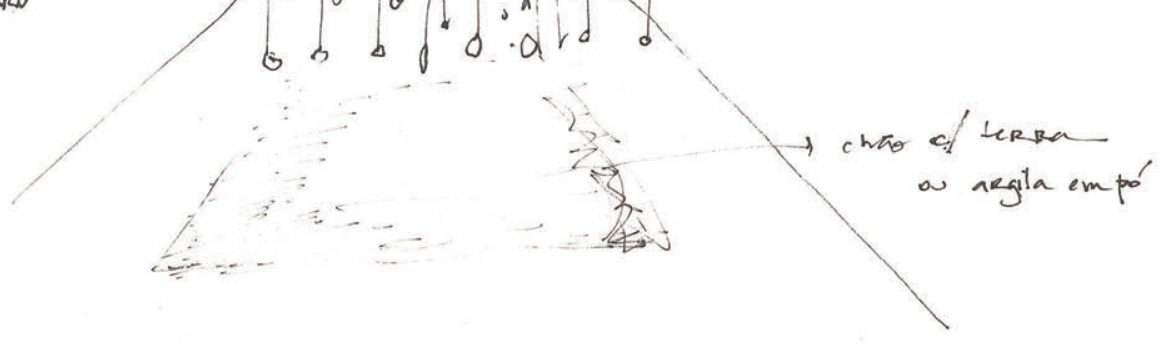


218 FLAVIA LEME DE ALMEIDA

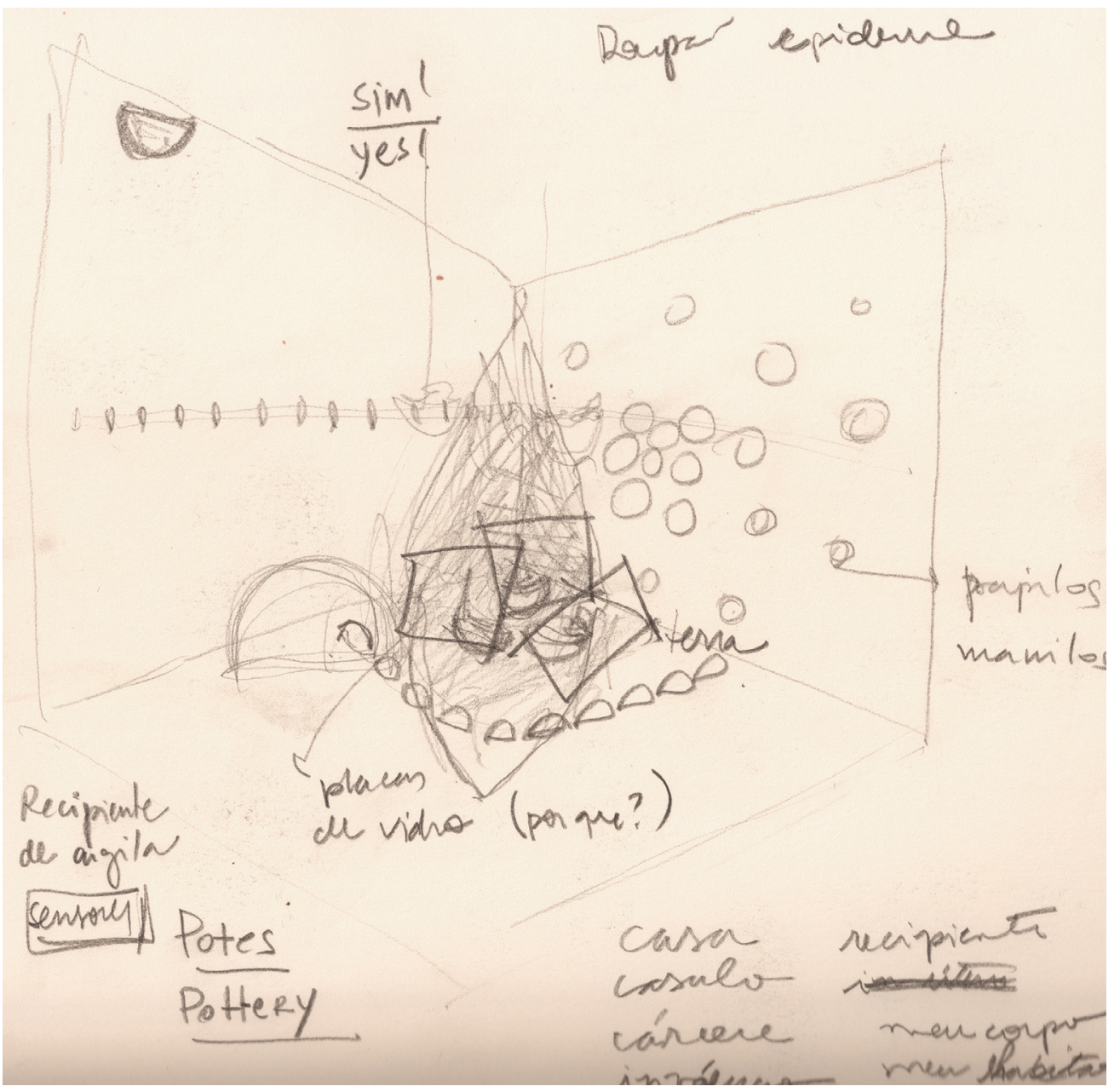




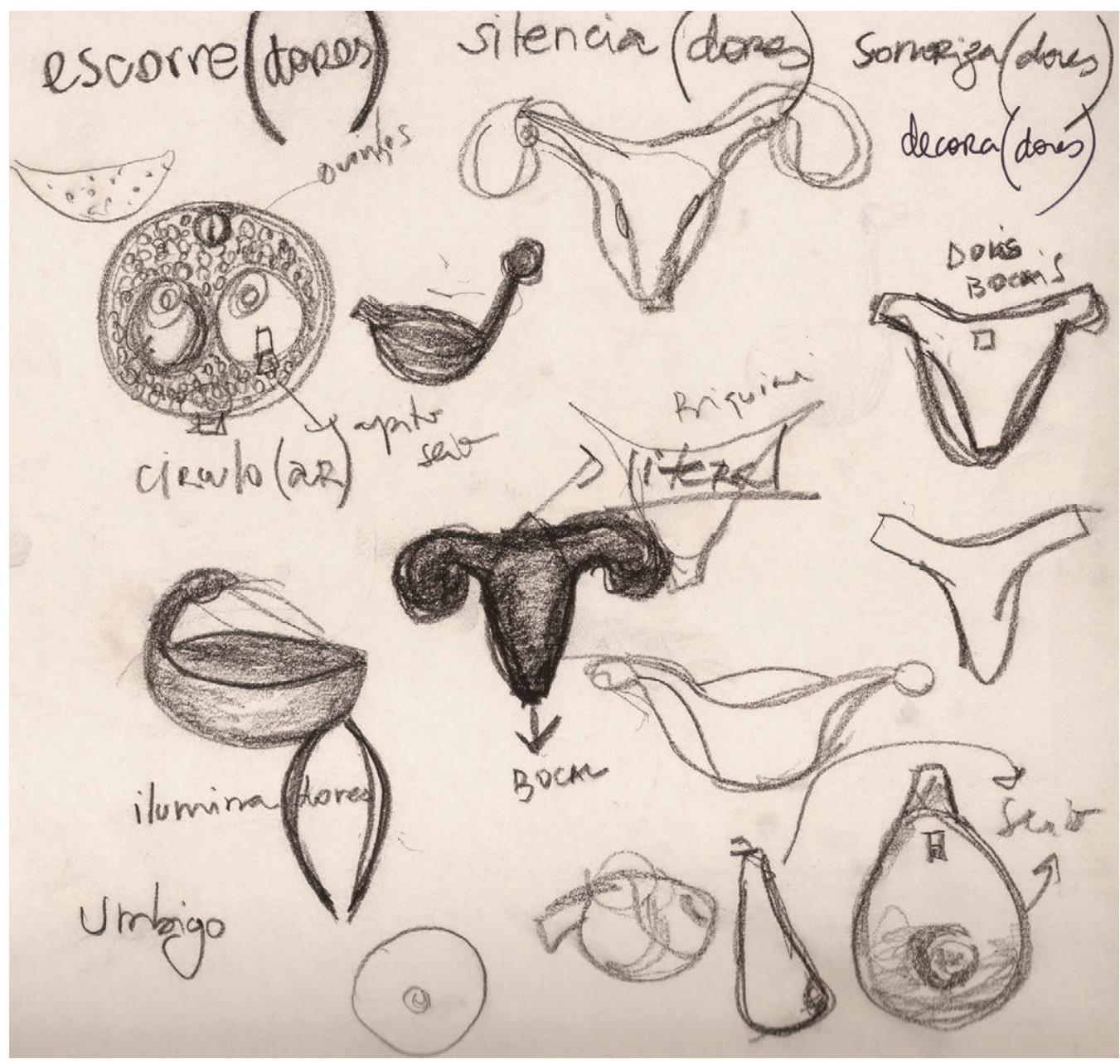




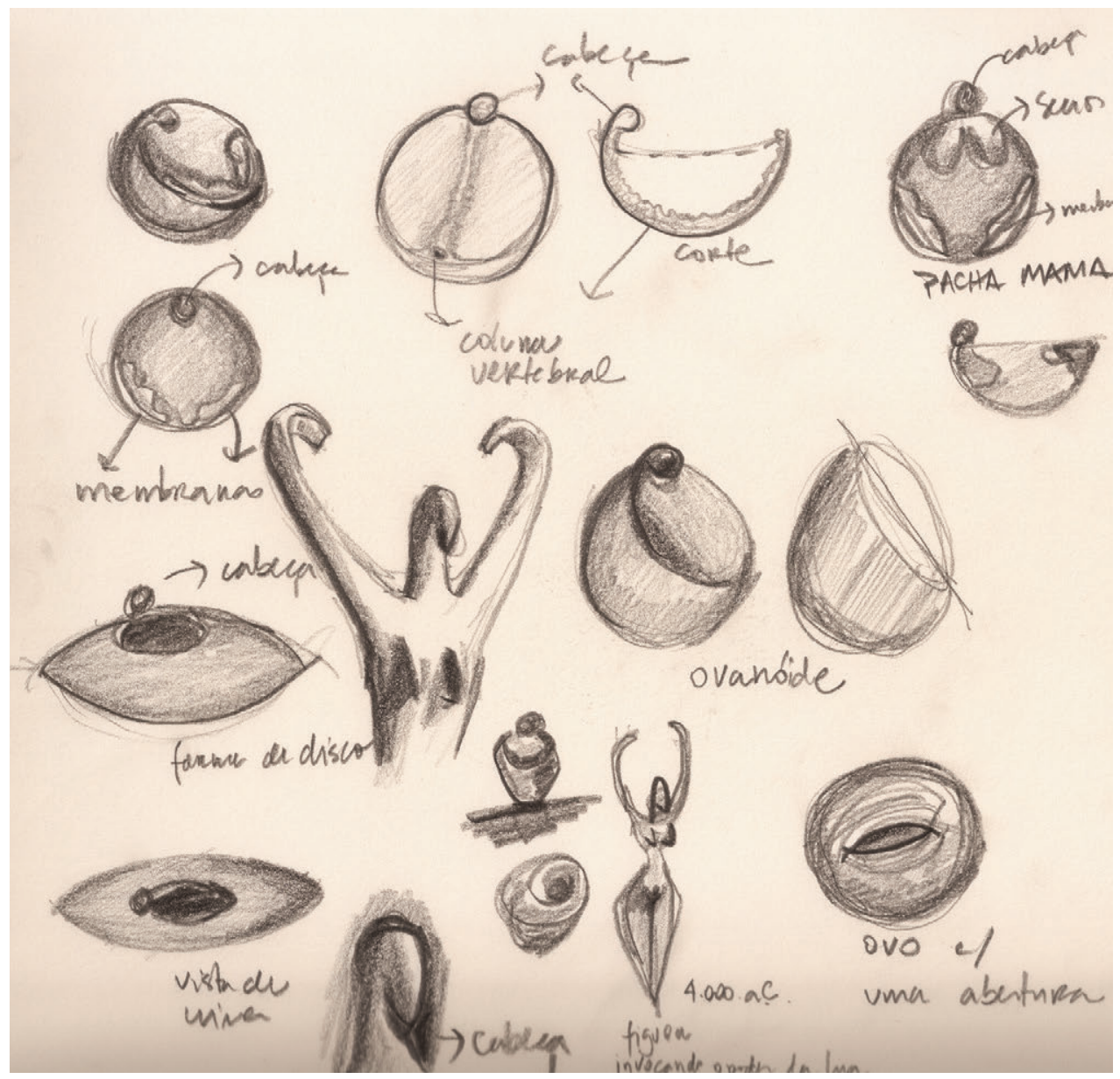



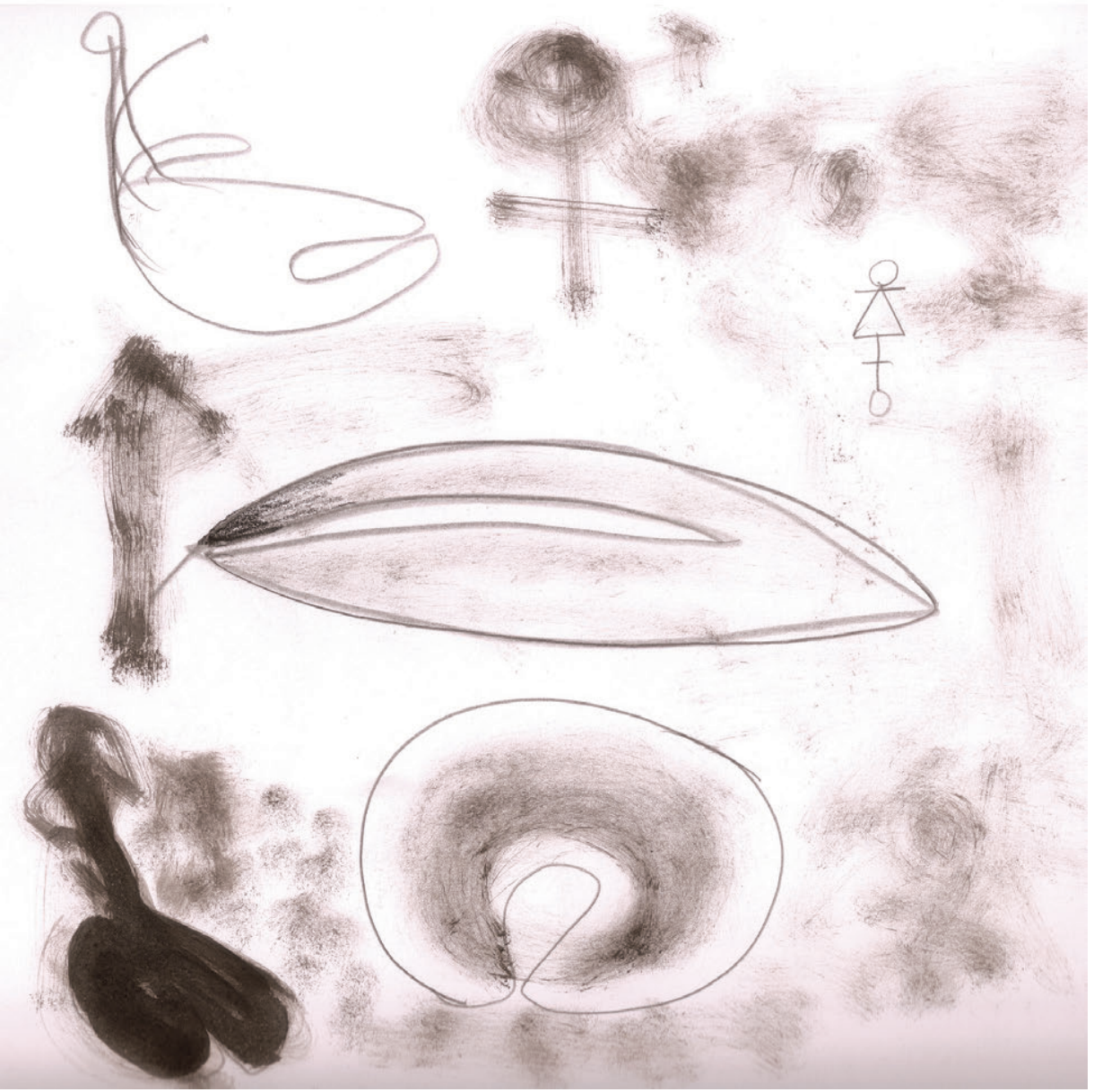
222 FLAVIA LEME DE ALMEIDA

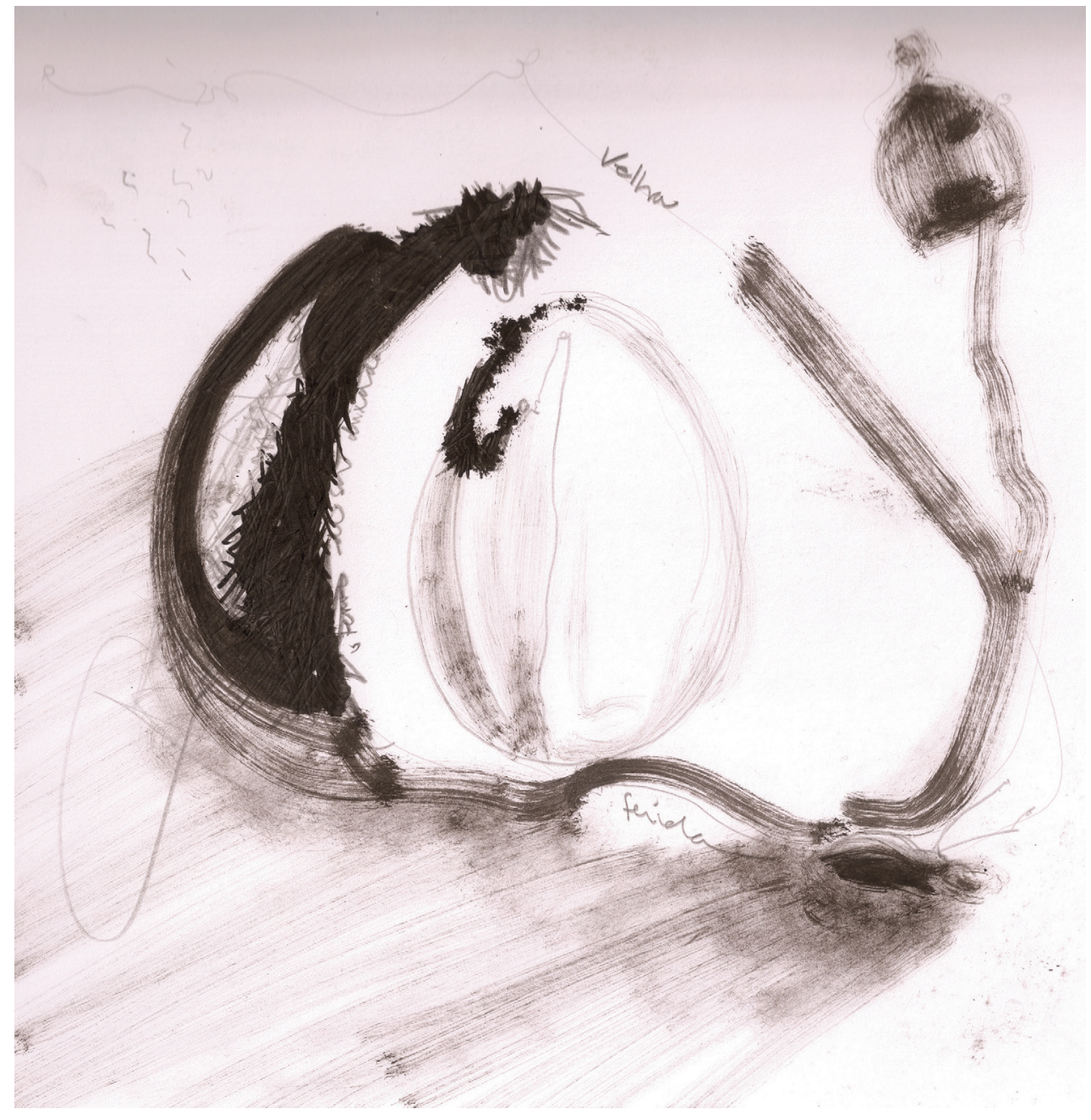




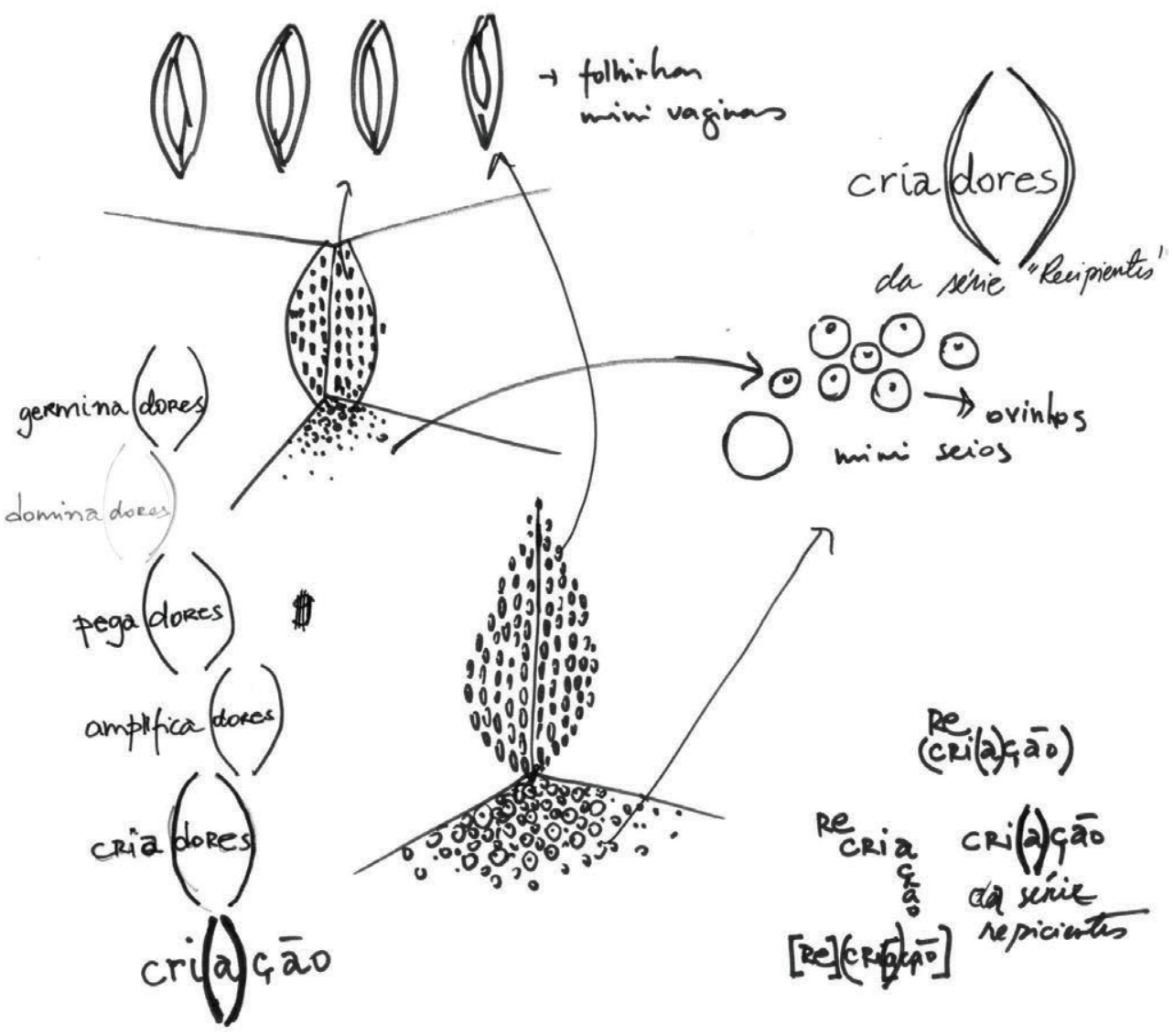


224

FLAVIA LEME DE ALMEIDA

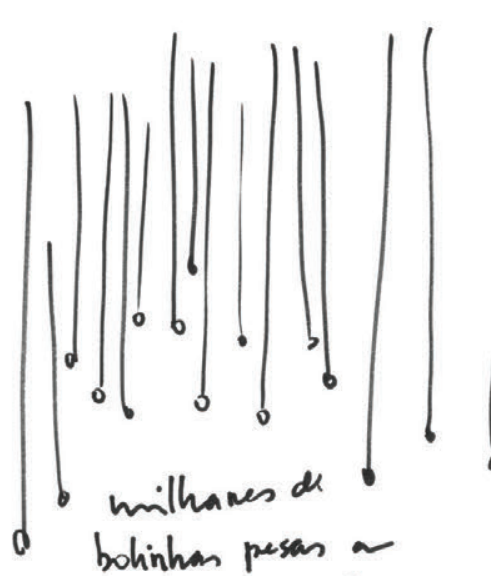

fir de mylox atheram (chocallos) variadon

no chat cacos de
cerámiar (som da quehran)

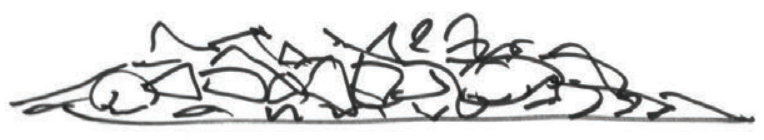

gronale

Recipiente ut chão (Terrs) com a'gre, prajiciōo nágre das pecas. Reipiets. 


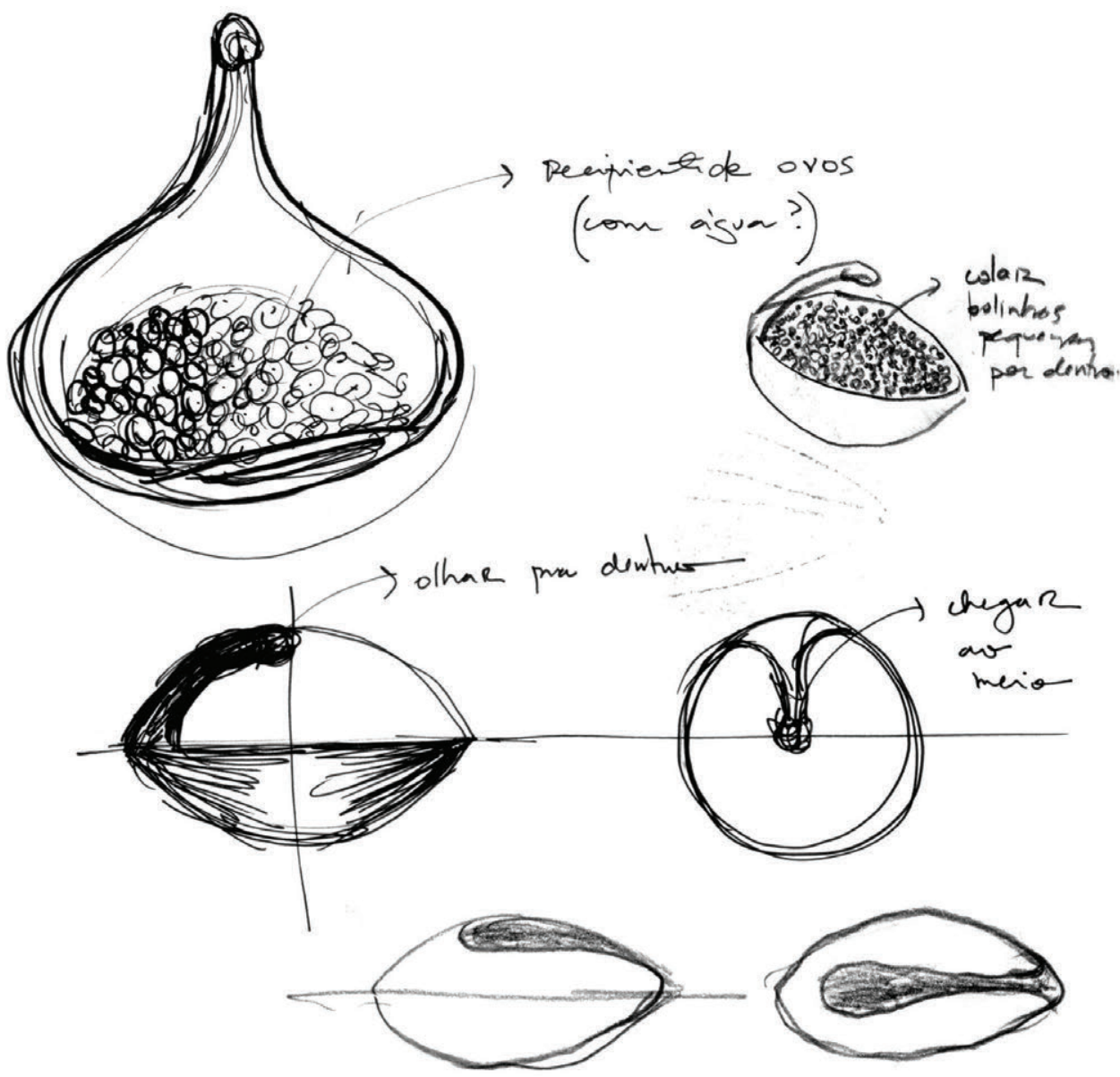


226

FLAVIA LEME DE ALMEIDA

Fayge un molde de 1, Tom de diametur (quase milhor alturea). Vecition medidas do formo elétrico.
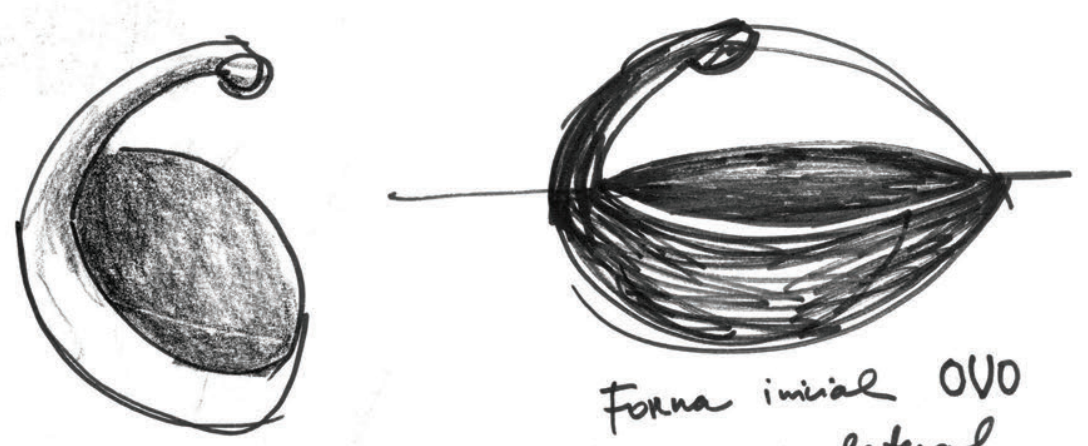

Forna iminal OVO apunas na lateral

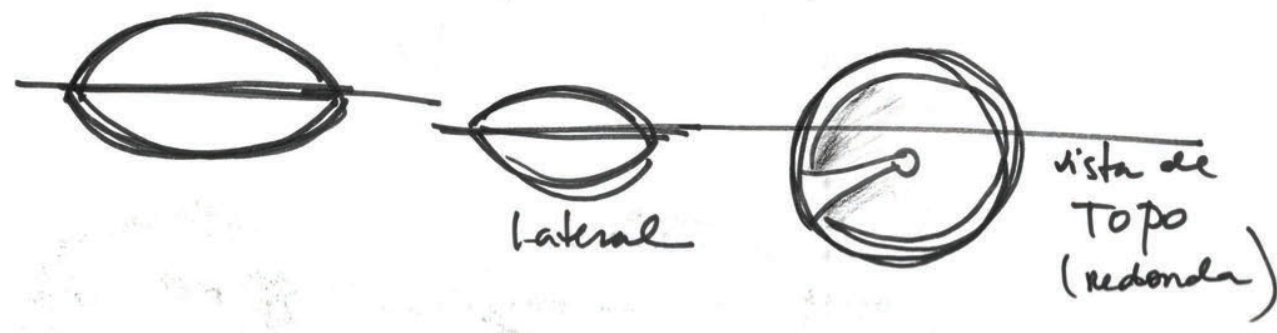


MULHERES RECIPIENTES $\quad 227$

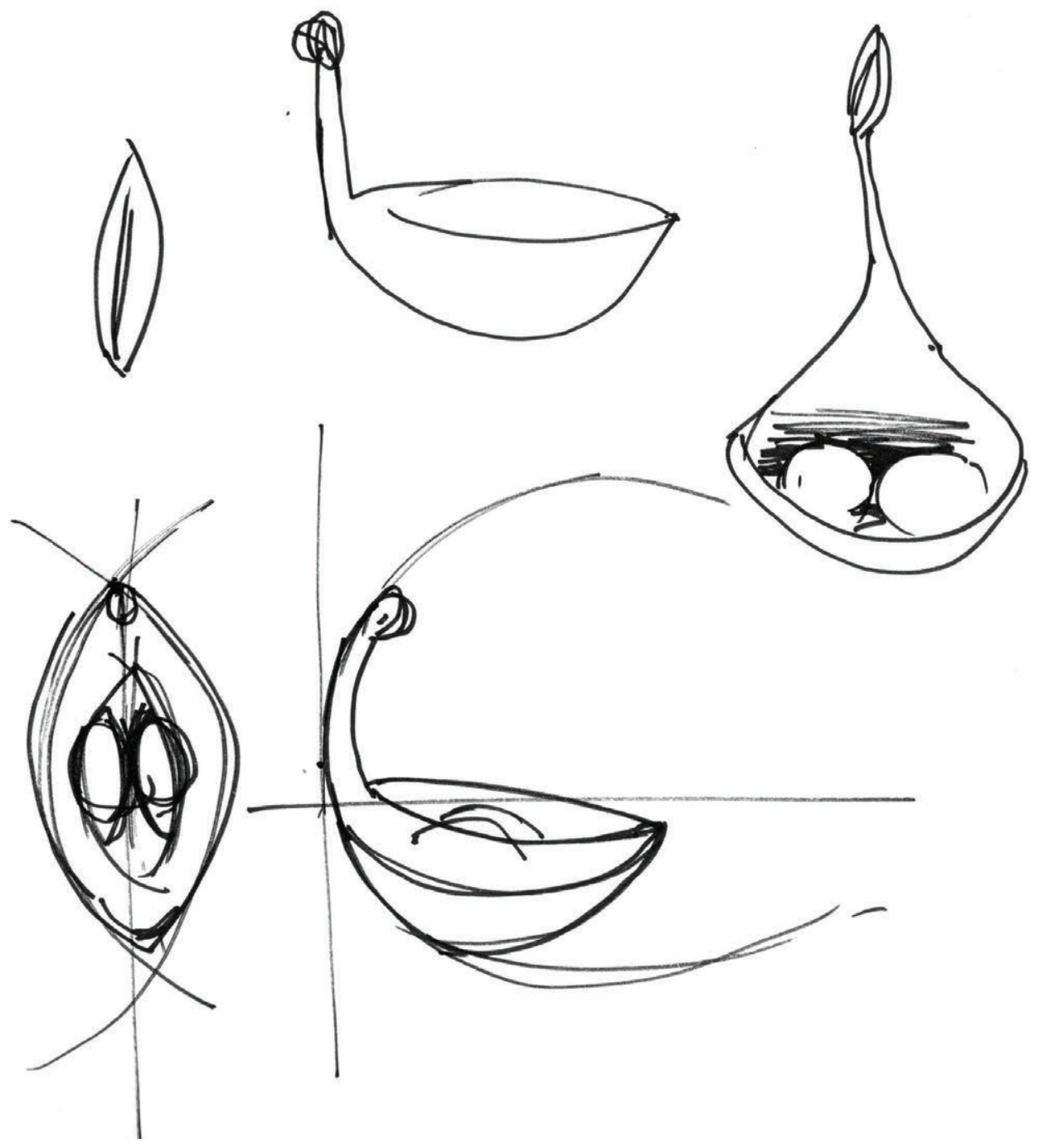





\section{REFERÊNCIAS BIBLIOGRÁFICAS}

ADES, D.; CATLIN, S. L.; O’NEILL, R. Arte na América Latina. A era Moderna (1820-1980). São Paulo: Cosac \& Naif, 1997.

ARGAN, G. C. Arte Moderna. Trad. Denise Bottmann e Fedrerico Carotti. São Paulo: Companhia das Letras, 1992.

BACHELARD, G. A poética do espaço. São Paulo: Martins Fontes, 1993. A terra e os devaneios do repouso. São Paulo: Martins Fontes, 2001.

BALZAC, H. de. A mulher de trinta anos. Trad. Paulo Neves. Porto Alegre: L\&M, 2007.

BENJAMIN, W. Obras escolhidas: magia e técnica, arte e política. Trad. Sérgio Paulo Rouanet. São Paulo: Brasiliense, 1986.

BEAUVOIR, S. de. Segundo sexo. Trad. Sérgio Milliet. São Paulo: Difel, 1970.

BÍBLIA. Português. Trad. Padre João Ferreira D’Almeida. Edição revista e corrigida. Rio de Janeiro: Sociedades Bíblicas Unidas, 1950.

BOURGEOIS, L; BERNADAC, M.-L.; OBRIST, H.-U. Louise Bourgeois, destruição do pai, reconstrução do pai. São Paulo: Cosac \& Naif, 2000.

BRETT, G. M. Earth body: sculptura and performance (1972-1985). Washington: Hirshhorn Museum, 2004.

CALABRESE, O. A linguagem da arte. Trad. Tânia Pellegrini. Rio de Janeiro: Editora Globo, 2002

CAMPBELL, J. As transformações do mito através do tempo. Trad. Heloysa de Lima Dantas. São Paulo: Cultrix, 1990a. 
O poder do mito. São Paulo: Palas Athena, 1990 b.

CAVALCANTI, R. O casamento do Sol com a Lua: uma visão simbólica do masculino e do feminino. São Paulo: Cultrix, 1993.

CHADWICK, W. Women, art, and society. London: Thames and Hudson, 1990 (World of art).

CHICAGO, J. The dinner party: a symbol of our heritage. New York: Anchor Books, 1979.

CINTO, S. Sandra Cinto: construção. Santiago de Compostela: Dardo DS, 2006.

DALGLISH, L. Noivas da seca: cerâmica popular do Vale do Jequitinhonha. São Paulo: Ed. da Unesp, 2006.

Mestre Cardoso: a arte da cerâmica amazônica. Belém (PA): Secretaria Municipal de Educação, 1996.

DOTTIN-ORSINI, M. A mulher que eles chamavam fatal: textos e imagens da misoginia fin-de-siècle. Trad. Ana Maria Scherer. Rio de Janeiro: Rocco, 1996.

DUBY, G.; PERROT, M. História das mulheres no ocidente: o século XX. Trad. Port. com rev. cient. Maria Helena da Cruz Coelho. Porto/São Paulo: Afrontamento/Ebradil, 1990.

ÉSTES, C. P. Mulheres que correm com os lobos: mitos e histórias do arquétipo da mulher selvagem. Trad. Waldéa Barcellos. Rio de Janeiro: Rocco, 1994.

FURLANI, L. M. T. Fruto proibido: um olhar sobre a mulher. São Paulo: Livraria Pioneira Editora, c. 1992.

GADON, E. W. The once and future goddess: a symbol for our time. New York: Harper San Francisco, c. 1989.

GETTY, A. A Deusa [Goddess]. Madrid: Edições del Prado, 1997.

GROSENICK, U. Women artists: mulheres artistas nos séculos XX e XXI. São Paulo: Taschen, 2005.

GUNTER, V. A. (Ed.). 500 figures in clay: ceramic artistic celebrate the human form. Nova York: Lark Books, 2004.

HARDING, M. E. Os mistérios da mulher antiga e contemporânea: uma interpretação psicológica do princípio feminino, tal como é retratado nos mitos, na história e nos sonhos. São Paulo: Edições Paulinas, 1985.

JANSON, H. W. Iniciação à História da Arte. Trad. Jefferson Luiz Camargo. 2.ed. São Paulo: Martins Fontes, 1996.

JUNG, C. G. O homem e seus símbolos. 20.ed. Rio de Janeiro: Nova Fronteira, 1977.

JÚNIOR, G. História de Djanira, brasileira de Avaré. São Paulo: Arcádia, 2000. 
KOLLONTAI, A. Marxisme et révolution sexuelle. Paris: Maspero, 1973.

LAMAS, B. S. As artistas: recortes do feminino no mundo das artes. Porto Alegre: Editora Artes e Oficio, 1997.

LOZANO, L.-M. Frida Kahlo. México: Coordinación Editorial, 2007.

LÉVI-STRAUSS, C. A oleira ciumenta. Trad. José António Braga Fernandes Dias. Lisboa: Edições 70, 1985.

MATOS, M. I. S. de; SOIHET, R (Orgs.). O corpo feminino em debate. São Paulo: Ed. da Unesp, 2003.

MALUF, M.; MOTT, M. L. Recônditos do mundo feminino. In: SEVCENKO, N. (Org.). História da vida privada no Brasil - República: da Belle Époque à Era do Rádio. Coord. Fernando A. Novais. São Paulo: Companhia das Letras, 1998. (Historia da vida Privada no Brasil ; 3)

NOCHLIN, L. Women, art, and power and other essays. Colorado: Icon Editions, Westview Press, 1988.

OSTROWER, F. Acasos e criação artística. 2.ed. Rio de Janeiro: Editora Campus, 1999.

PARKER, R.; POLLOCK, G. Old mistresses: women, art and ideology. Nova York: Pantheon, 1981.

PHAIDON. 30.000 years of art. The story of human creativity across time and space. London/New York: Phaidon Press, 2007.

PRIORE, M. del (Org.). História das mulheres no Brasil. 9.ed. São Paulo: Contexto, 2008.

QUALLS-CORBETT, N. A prostituta sagrada: a face eterna do feminino. Trad. Isa F. Leal Ferreira. São Paulo: Edições Paulinas, 1990 (Amor e Psique).

RAMPAZZO, L. Metodologia científica [para alunos dos cursos de graduação e pós-graduação]. São Paulo: Edições Loyola, 2002.

RILKE, R. M. Cartas a um jovem poeta. Trad. Pedro Süssekind. Porto Alegre: L\&PM, 2007.

SATRE, J.-P. A imaginação. Trad. Paulo Neves. Porto Alegre: L\&PM, 2008.

\section{Teses, dissertarções e monografias}

ABREU, S. R. de. Frida Kahlo e Ismael Nery: aproximações e divergências. Dissertação (Mestrado) - Programa de Pós-Graduação em Integração da América Latina da Universidade de São Paulo. Prolam/ USP. São Paulo, 2008. 
BERTOLI, M. A sedução dos contrários na arte da América Latina: através da análise comparada da produção artística de Francisco Brennand e Gilvan Samico (Brasil), de Oswaldo Viteri (Equador) e de Gustavo Nakle (Uruguai). Tese (doutorado) - Programa de Pós-Graduação em integração da América Latina da Universidade de São Paulo. Prolam/ USP. São Paulo, 2003.

BORTOLIN, R. Ninho, casa e corpo. Dissertação (Mestrado) - Escola de Comunicação e Artes da Universidade de São Paulo. CAP/ECA/ USP. São Paulo, 2006. 132 p.

CABAÑAS PEDRO, C. C. A arquitetura de Niki de Saint Phalle-O Jardim de Tarô. Dissertação (Mestrado) - Instituto de Artes da Universidade Estadual Paulista/UNESP. São Paulo, 2008.

CÂMARA, M. L. Z. A figura feminina na escultura - do primitivo ao contemporâneo. Trabalho de Conclusão de Curso - Bacharelado em Artes Plásticas. Instituto de Artes da Universidade Estadual Paulista/ UNESP. São Paulo: [s.n.], 1999.

DALGLISH, G. M. F. S. A arte do barro na América Latina: um estudo comparado de aspectos estéticos e socioculturais na cerâmica popular do Brasil e do Paraguai. São Paulo: [s.n.], 2004. 268 f.: il..

FORTESJUNIOR, H.F.S. Poéticas contemporâneas: aágua na artecontemporânea. Tese (doutorado) - Escola de Comunicação e Artes da Universidade de São Paulo/CAP/ECA/USP. São Paulo: [s.n.], 2006.

GRINBERG, N. T. Humanóides: transmutações da forma e da matéria. Tese (doutorado) - Escola de Comunicação e Artes da Universidade de São Paulo/CAP/ECA/USP. São Paulo: [s.n.], 1994. 78 p.

HENNING, I. Celeida Tostes: o ventre da terra. Dissertação (Mestrado) Escola de Belas Ates do Rio de Janeiro/UFRJ/EBA. Rio de Janeiro, 2008. 168 p.

MEDEIROS, V. de. Mulher pré-moldada: uma poética do invisível na imagem feminina. Dissertação (Mestrado) - Escola de Belas Artes da Universidade Federal da Bahia - UFBA. Salvador: [s.n.], 1995. 342 p.

MIRANDA. Z. C. de. Impressões em cerâmica: convite ao encontro caótico entre a cerâmica, a gravura e o fogo. Tese (doutorado) - Universidade Estadual de Campinas (Unicamp). Campinas, SP: [s.n.], 2008. 142 p.

PINTO, R. C. Quatro olhares à procura de um leitor: mulheres importantes, arte e identidade. Dissertação de Mestrado - Escola de Belas Artes da Universidade Federal do Rio de Janeiro. Rio de Janeiro: [s.n.], 1994. 
RAMPAZZO, L. G. Djanira na arte brasileira. 1993. Tese (Doutorado)Escola de Comunicações e Artes da Universidade de São Paulo/ECA/ USP, São Paulo, 1993. 222 p.

SENNA, N. da C. Donas da beleza: a imagem feminina na cultura ocidental pelas artistas plásticas do século XX. Tese (Doutorado) - Escola de Comunicação e Artes da Universidade de São Paulo. CAP/ECA/ USP. São Paulo, 2007. 212 p.+ anexos.

SILVEIRA, M. B. Tecer o barro: uma construção de percursos e conexões da cerâmica hipermídia. / Dissertação (Mestrado) - Escola de Comunicação e Artes da Universidade de São Paulo - CAP/ECA/USP. São Paulo, 2006. 70 p.+ CD-ROM.

XAVIER, K. de O. Corpo estranho. Dissertação (Mestrado) - Escola de Comu nicação e Artes da Universidade de São Paulo - CAP/ECA/ USP. São Paulo, 2008. 63 p.il + (2) DVDs

\section{Catálogos}

AMARAL, A. Tarcila do Amaral. Projeto Cultura - Artistas do Mercosul. Buenos Aires: Banco Velox, 1998.

ANTES: HISTÓRIAS DA PRÉ-HISTÓRIA. Idealização concepção e desenho expositivo [por] Marcelo Dantas. Rio de Janeiro/Brasília: Centro Cultural Banco do Brasil, 2003.

BALTAR, B. Catálogo da exposição A coleta da neblina 1996/2001 de Brígida Baltar. São Paulo: Galeria Nara Roesler, 2001.

BRENNAND. Exposição na Pinacoteca do Estado de são Paulo. Curadoria Olívio Tavares de Araújo. São Paulo, 22 de setembro a 15 de novembro de 1998.

21a BIENAL INTERNACIONAL DE SÃO PAULO. Celeida Tostes. Catálogo geral da Fundação Bienal de São Paulo, 1991.

Iconografias Metropolitanas - Cidades. São Paulo: Fundação Bienal de São Paulo, 2002.

COSTA, M. de L. Arte do fogo, do sal e da paixão-Celeida Tostes. Rio de Janeiro: CCBB, 2003

DAHER, A. Surrealismo. Rio de Janeiro: CCBB, 2001.

NORMA GRINBERG: OBRAS RECENTES = RECENTS WORKS.

Curitiba: Museu de Arte Contemporânea do Paraná, 1994.

STAHL, H. V. Celeida Tostes. Bienal Internacional de São Paulo, 21., 1991. Catálogo geral. p.195-196. 
TERRA COTAS DA TERRA 2004. Exposição coletiva; Notas bibliográficas; depoimentos do artista. 24 p.: il. col e pb.

PINACOTECA DO ESTADO DE SÃO PAULO. Tesouros do Senhor de Sipán Peru: o esplendor da cultura Mochica. São Paulo: Stilgraf Gráfica e Editora, 2006.

\section{Dicionários}

CIRLOT, J.-E. Dicionário de símbolos. Trad. Rubens Eduardo Ferreira Frias. São Paulo: Edições Moraes, 1984.

CUNHA, A. G. da. Dicionário etimológico Nova Fronteira da língua portuguesa. Rio de Janeiro: Nova Fronteira, 1986.

CUNHA, N. Dicionário Sesc: a linguagem da cultura. São Paulo: Perspectiva/Sesc São Paulo, 2003.

FERREIRA, A. B. de H. Novo Dicionário da Língua Portuguesa. Rio de Janeiro: Nova Fronteira, 1975.

HOUAISS, A. e VILLAR, M. de S. Dicionário Houaiss da Língua Portuguesa. Elaborado no Instituto Antonio Houaiss de Lexicografia e Banco de Dados da Portuguesa. Rio de Janeiro: Objetiva, 2001.

\section{Sites}

AFONSO, L. Loiuse Bourgeios. Disponível em: http://artecapital.net/ criticas.php?critica $=154$. Acesso em 22/09/08 às $8 \mathrm{~h}$.

BARRERAS DEL RIO, P. An historical overview: Ana Mendieta Retrospective. Nova Iorque: New Museum, 1987, p.31. Apud BRETT, G. Mendieta Earth Body: sculptura and performance, 1972-1985. Washington: Hirshhorn Museum, 2004. Disponível em: http://www2.sescsp.org.br/sesc/videobrasil/up/arquivos/200607/20060710_124405_Ens_AMendieta_GBrett_CVB_P. pdf. Acesso em: 11/06/09 às 9h.

ENCYCLOPÉDIA. Women artists. Disponível em: http://www.nationmaster.com/encyclopedia/Women-Artists. Acesso em 13/06/09 às $22 \mathrm{~h} 45$

BRIGAGÃO, C. Celeida Tostes: mó e bastões. Disponível em: http:// www.itaucultural.org.br/aplicExternas/enciclopedia_IC/ in- 
dex.cfm?fuseaction $=$ artistas_criticas $\&$ cd_verbete $=1380 \& \mathrm{~cd}$ item $=15 \& c d \_i d i o m a=28555$ Acesso em: $13 / 08 / 08$ às $14 \mathrm{~h} 21$.

PINTURA DE GENERO. Disponível em: http://www.itaucultural.org. $\mathrm{br} /$ aplicExternas/enciclopedia_IC/index.cfm?fuseaction=termos_ texto\&cd_verbete $=912$ Acesso em 14/06/09 às $8 \mathrm{~h}$.

COMENTÁRIO CRÍTICO DE TADEU CHIARELLI SOBRE A OBRA DE SANDRA CINTO. Disponível em: http://www.itaucultural.org. $\mathrm{br} /$ aplicExternas/enciclopedia_IC/index.cfm?fuseaction=artistas_ biografia\&cd_verbete $=3271 \& c d \_i t e m=2 \& c d \_i d i o m a=28555$. Aces so em 20/06/09 às $21 \mathrm{~h}$.

COMENTÁRIO CRÍTICO DA OBRA DE BRÍGIDA BALTAR. Disponível em: http://www.itaucultural.org.br/aplicExternas/ enciclopedia_IC/index.cfm?fuseaction $=$ artistas_biografia\&cd verbete $=1286 \& c d \_i t e m=2 \& c d \_i d i o m a=28555$. Acesso em 20/06/09 às $21 \mathrm{~h} 30$

FRANCOIO, M. Â. S. Anita Malfatti. Disponível em: http:// www.macvirtual.usp.br. Acesso em: 14/06/09 às 19h.

GAUDICHON, B. e RIVIÈRE, A. Camille Claudel. Disponível em: http://www.camilleclaudel.asso.fr/pageweb/agemur.html. Acesso em 14/06/09 às $17 \mathrm{~h}$.

LIMA, M. Psicanálise e cultura. Artigo disponível em: http://www.pedagobrasil.com.br/psicologia/educacaopsicanalise.htm. Acesso em 22/07/08 às $18 \mathrm{~h} 30$.

LOPONTE, L. G. Sexualidades, artes visuais e poder: pedagogias visuais do feminino. Artigo da Revista Estudos Feministas, v.10 n.2. Universidade Federal do Rio Grande do Sul. Florianópolis. Julho/ Dec. 2002. Disponível em: http://www.scielo.br/scielo. php? script $=$ sci_arttext\&pid $=$ S0104-026X2002000200002. Acesso em 05/07/08 às $11 \mathrm{~h} 30$.

RIVITTI, T. $27^{\mathrm{a}}$ Bienal Internacional de São Paulo. Disponível em: http://diversao.uol.com.br/27bienal/artistas/ana_mendieta.jhtm Acesso em: 13/08/08 às 16h20.

SACCÁ, L. Corpo como experimento. Nossa América (on line). Revista Memorial América Latina. n.23, ano 2006. Disponível em: http:// www.memorial.sp.gov.br/revistaNossaAmerica/23/ port/26Corpo_como_experiencia.htm. Acesso em 11/06/09 às $16 \mathrm{~h} 30$.

SANTOS, R. M. dos. Os discursos sobre a mulher entre o sagrado e o profano. Apud OPSIS - Revista do NIESC, v.6, 2006. Disponível em: 
www.catalao.ufg.br/historia/revistaopsis/arqpdf/OPSIS2006.pdf. Acesso em 05/07/08 s 12h45.

SILVA, A. C. L. F. da. Hildegarda de Bingen e as sutilezas da natureza de diversas criaturas. Universidade Federal do Rio de Janeiro/CNPq. Disponível em: www.ifcs.ufrj.br/ frazao/Bingen.htm. Acesso em: $13 / 06 / 09$ às $22 \mathrm{~h} 30$

TOULZE, M. A influência dos feminismos em artistas da França e do Ultramar nos anos 70. Labrys, estudos feministas. Trad.: Tania Navarro Swain. n.3, jan.- jul. 2003. Disponível em: http://www.unb.br/ $\mathrm{ih} / \mathrm{his} / \mathrm{gefem} /$ labrys3/web/bras/marielle1.htm Acesso 24/04/09 às $12 \mathrm{~h}$.

VOlPATTO, R. Pachamama, a Deusa de toda a vida. Disponível em: http://rosanevolpatto.trd.br/Pachamama.html. Acesso em: 28/09/08 às 20:12. 


\section{FILMOGRAFIA}

As Horas (The Hours)

Produção: EUA, 2002.

Direção: Stephen Daldry.

Duração: 115 min. Drama. DVD, colorido.

Sinopse: relata o que se passa num dia da vida de três mulheres, em épocas diferentes, que têm entre si uma única aparente conexão: o romance Mrs. Dalloway. Nos anos 1920, a própria Virginia Woolf (Nicole Kidman) se recupera da última crise de esquizofrenia quando tem a ideia para a frase de abertura do livro: "Mrs. Dalloway decidiu que iria ela mesma comprar as flores”. Na Los Angeles pós-Segunda Guerra, em 1952, Laura Brown (Julianne Moore), uma dona-de-casa infeliz com sua aparente vida perfeita, começa a ler Mrs. Dalloway, história que vai afetar a sua vida para sempre. Enquanto isso, na Nova York de 2001, Clarissa Vaughan (Meryl Streep) decide ela mesma comprar as flores para a festa que homenageará o amigo, ex-amante e poeta Richard Brown, que está morrendo com Aids. Ela reviverá, de certa maneira, a saga do romance de Virginia Woolf. Para o diretor Stephen Daldry, a essência deste filme é seu profundo respeito pelas mulheres e os desafios que enfrentaram ao longo dos turbulentos e imprevisíveis acontecimentos do século XX. Designação do material: observação e análise sobre os diferentes modos comportamentais de três gerações de mulheres do século XX; suas relações perante os homens, a sociedade e a vida. 


\section{Camille Claudel}

Produção: França, 1988.

Direção: Bruno Nuytten.

Duração: 166 mim. Drama biográfico. Longa-metragem, colorido.

Sinopse: Em Paris, em 1885, a jovem escultora Camille Claudel (Isabelle Adjani), irmã do escritor Paul Claudel (Laurent Grévill), entusiasma e impressiona o famoso escultor Auguste Rodin (Gérard Depardieu). Porém entra em conflito com sua família burguesa ao tornar-se aprendiz e, depois, assistente do famoso Auguste Rodin.

Quando ela se transforma em amante do mestre (que já era casado), cai em desgraça junto à sociedade parisiense, embora tenha amigos do porte do compositor Claude Debussy. Depois de quinze anos de tortuoso relacionamento com Rodin, Camille rompe o romance e mergulha cada vez mais na solidão e na loucura. Por iniciativa de seu irmão mais novo, Paul Claudel, é internada em 1912 num manicômio onde vive muitos anos até sua morte.

Designação do material: o estudo sobre as diversas questões que envolviam uma mulher artista do século XIX; especialmente o modo como a sociedade francesa da época, aristocrática e conservadora, apenas reconhecia apenas uma mulher como artista se sua imagem estivesse, necessariamente, atrelada a uma figura masculina.

Frida

Produção: Lindsay Flickinger, Sarah Green, Nancy Hardin, Salma Hayek, Jay Polstein, Roberto Sneider e Lizz Speed. EUA, 2002.

Direção: Julie Taymor

Duração: 123 minutos. Drama. DVD, colorido.

Sinopse: Frida Kahlo (Salma Hayek) foi um dos principais nomes da história artística do México. Conceituada e aclamada como pintora, ele teve também um casamento aberto com Diego Rivera (Alfred Molina), seu companheiro também nas artes, e ainda um controverso caso com o político Leon Trostky (Geoffrey Rush) e com várias outras mulheres.

Designação do material: neste filme foram observados os aspectos biográficos da artista que estão, direta e intrinsecamente, relacionados com sua obra artística. 


\author{
SOBRE O LIVRO \\ Formato: $14 \times 21 \mathrm{~cm}$ \\ Mancha: 23,7 x 42,5 paicas \\ Tipologia: Horley Old Style 10,5/14 \\ 1a edição: 2010 \\ EQUIPE DE REALIZAÇÃO \\ Coordenação Geral \\ Marcos Keith Takahashi
}




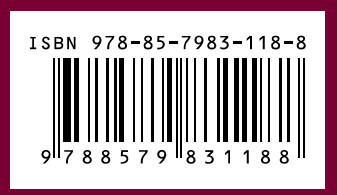

